LBL-34946

\title{
DOE-2
}

\section{BDL SUMMARY}

\section{Version 2.1E}

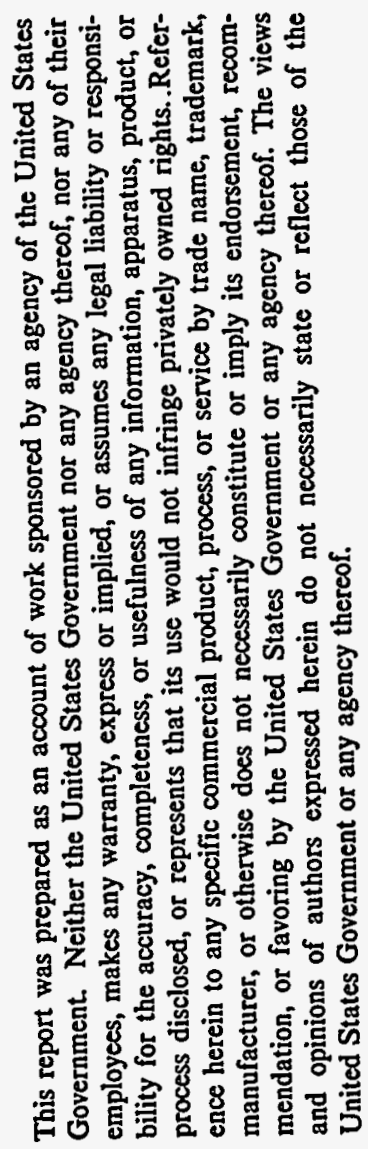

F.C. Winkelmann, B.E. Birdsall, W.F. Buhl, K.L. Ellington, A.E. Erdem Energy and Environment Division Lawrence Berkeley Laboratory University of California Berkeley, CA 94720 and

J.J. Hirsch and S. Gates Hirsch \& Associates Camarillo, CA 93102

(c) 1003. Regents of the University of California, Lawrence Berkeley Laboratory. This work was supported by the Assistant Secretary for Energy Eflielency and Renewable Energy, Office of Building Technologies, Bullding Systems and Materials Division of the U.S. Department of Energy, under Contract No. DE-AC03-7 0SF00008. Support for Version 2.1E was also provided by Southern California Edison Company, Pacific Gas and Electric Company, Gas Research Institute (via ElectroCom GARD, Ltd.), Electric Power Research Institute, Pacific Northwest Laboratory, and the IEA Solar Heating and Cooling Programme. Lawrence Berkeley Laboratory is an Equal Opportunity Employer. 


\section{Table of Contents}

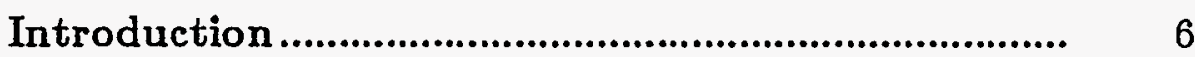

Key to Command and Keyword Summary .............. 6

\section{LOADS}

Command and Keyword Summary ............................... $\quad 7$

INPUT LOADS ............................................... 7

PARAMETRIC-INPUT LOADS ........................ 7

LIBRARY-INPUT LOADS................................ 7

TITLE ............................................................ 7

ABORT ….................................................... 7

DIAGNOSTIC ................................................. 7

RUN-PERIOD ................................................ 7

BUILDING-LOCATION.................................. 8

ALT-HOLIDAYS.............................................. 8

PARAMETER ..................................................... 8

SET-DEFAULT ............................................. 9

DESIGN-DAY ............................................ 9

DAY-SCHEDULE ............................................ 9

WEEK-SCHEDULE ....................................... 10

SCHEDULE .................................................... 10

MATERIAL ........................................................ 11

CONSTRUCTION........................................... 11

LAYERS .......................................................... 11

GLASS-TYPE ............................................ 13

BUILDING-SHADE....................................... 14

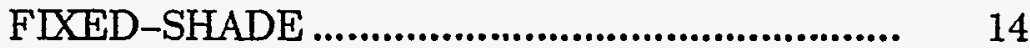

WALL-PARAMETERS..................................... 15

SPACE-CONDITIONS ..................................... 16

SPACE ...................................................... 18

EXTERIOR-WALL or -ROOF ......................... 19

TROMBE-WALL-V or -NV ............................. 20

WINDOW ...................................................... 21

DOOR .......................................................... 23

INTERIOR-WALL .......................................... 24

UNDERGROUND-WALL or -FLOOR .............. 25

BUILDING-RESOURCE.................................... 25

LOADS-REPORT ......................................... 25

REPORT-BLOCK .......................................... 25

HOURLY-REPORT ........................................ 26

END ........................................................ 26

FUNCTION.............................................. 26 


\section{DISCLAIMER}

Portions of this document may be illegible in electronic image products. Images are produced from the best available original document. 
ASSIGN ....................................................... $\quad 26$

CALCULATE ................................................... 26

END-FUNCTION ........................................ 26

COMPUTE LOADS ........................................ 27

SAVE-FILES ................................................. 27

STOP ....................................................... 27

\section{SYSTEMS}

Command and Keyword Summary........................... 28

INPUT SYSTEMS........................................... 28

PARAMETRIC-INPUT SYSTEMS .................. 28

TITLE .......................................................... 28

ABORT ....................................................... 28

DIAGNOSTIC ............................................... 28

PARAMETER ............................................... 28

CURVE-FIT .................................................. 28

DAY-SCHEDULE ......................................... 28

WEEK-SCHEDULE....................................... 28

SCHEDULE.................................................. 29

DAY-RESET-SCH....................................... 29

RESET-SCHEDULE .................................... 29

ZONE-CONTROL ........................................... 29

ZONE-AIR .................................................. 30

ZONE-FANS ................................................... 30

ZONE ........................................................... 31

SYSTEM-CONTROL...................................... 33

SYSTEM-AIR .................................................. 33

SYSTEM-FANS ............................................ 34

SYSTEM-TERMINAL ..................................... 35

SYSTEM-FLUID .............................................. 35

SYSTEM-EQUIPMENT .................................. 36

SYSTEM .................................................... 39

SUBR-FUNCTIONS ..................................... 42

PLANT-ASSIGNMENT ................................... 43

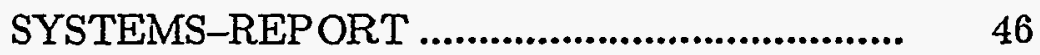

REPORT-BLOCK........................................ 46

HOURLY-REPORT ....................................... 46

END ...................................................... 46

FUNCTION.................................................. 46

ASSIGN ........................................................ 46

CALCULATE ................................................... 46

END-FUNCTION ......................................... 46

COMPUTE SYSTEMS.................................. 46

SAVE-FILES ............................................... 46

STOP ........................................................ 46 


\section{PLANT}

Command and Keyword Summary ............................. 47

INPUT PLANT ................................................. 47

PARAMETRIC-INPUT PLANT ...................... 47

TITLE ...................................................... 47

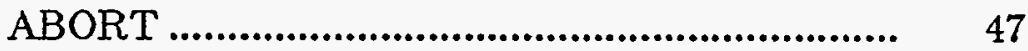

DIAGNOSTIC ................................................ 47

PARAMETER .................................................... 47

CURVE-FIT ..................................................... 47

DAY-ASSIGN-SCH .......................................... 47

DAY-SCHEDULE …......................................... 47

WEEK-SCHEDULE ....................................... 47

SCHEDULE ................................................. 48

PLANT-ASSIGNMENT .................................... 48

PLANT-EQUIPMENT ....................................... 48

PART-LOAD-RATIO........................................ 50

PLANT-PARAMETERS................................... 51

EQUIPMENT-QUAD ...................................... 55

HEAT-RECOVERY .......................................... 56

LOAD-ASSIGNMENT .................................... 56

ENERGY-STORAGE ...................................... 57

LOAD-MANAGEMENT ................................... 57

PLANT-COSTS ............................................ 57

ENERGY-RESOURCE ................................... 58

REFERENCE-COSTS .................................... 58

PLANT-REPORT ......................................... 58

REPORT-BLOCIK........................................... 58

HOURLY-REPORT ........................................ 58

END …....................................................... 58

COMPUTE PLANT ...................................... 58

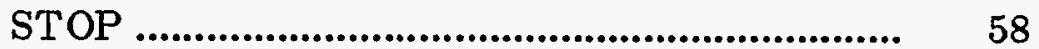

\section{ECONOMICS}

Command and Keyword Summary ............................. $\quad 59$

INPUT ECONOMICS .................................... 59

PARAMETRIC-INPUT ECONOMICS.............. 59

TITLE …................................................... 59

ABORT …....................................................... 59

DIAGNOSTIC .............................................. 59

PARAMETER ................................................. 59

DAY-SCHEDULE ........................................... 59

WEEK-SCHEDULE......................................... 59

SCHEDULE .................................................. 59

BLOCK-CHARGE ....................................... 59

UTLITY-RATE ............................................. 60

RATCHET ................................................ 60 
COMPONENT-COST ................................. 61

BASELINE .................................................... 61

ECONOMICS-REPORT ................................ 61

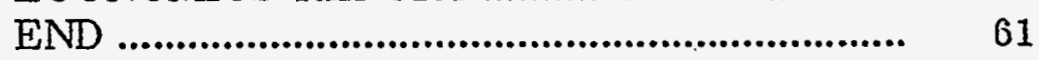

COMPUTE ECONOMICS .............................. 61

STOP ....................................................... 61

\section{REFERENCE MATERIAL}

Applicability Tables and Index of System Types...... 62

Verification and Summary Report Titles................... 116

Materials Library .................................................... 118

Window Library................................................... 126

Geographical Data for the 50 Largest U.S. Cities ...... 133

International Time Zone Map .................................. 135

Perpetual Calendar ............................................. 137 


\section{Introduction}

This document contains summary information on all commands and keywords in the DOE-2 Building Description Language (BDL). It also contains supplementary tables and maps. The fundamentals of BDL are discussed in Chapter II of the Reference Manual (2.1A); detailed descriptions of the commands and keywords summarized here can be found in the Reference Manual (2.1A) and in the Supplement (2.1E).

You are also referred to the Alphabetical List of Commands and Keywords Found in DOE-2 (Appendix F of the Supplement (2.1E)). This list includes all commands and keywords in the current version of DOE-2 and where they are found in the documentation. The list is updated yearly and printed in the summer issue of the DOE-2 User News. Copies of the list may be obtained by writing to the Simulation Research Group, Bldg. 90-Room 3147, Lawrence Berkeley Laboratory, Berkeley, CA 94720 (or FAX us at 510-486-4089).

\section{Key to Command and Keyword Summary:}

COMMAND(abbreviation, maximum number allowed) [comments]

- KEYWORD(abbreviation)(default;range and units)

- KEYWORD(abbreviation)(default;range and units)

KEYWORD(abbreviation)(default;range and units)

Note: The most often used keywords are printed above a demarcation line (a row of double dots); those that are more advanced or of special use are printed below the demarcation line.

A bullet $(\bullet)$ indicates a required keyword

A black box $(\boldsymbol{)})$ indicates an addition or change in DOE-2.1E

\section{Notes:}

1. The most frequently used commands and keywords are in boldface.

2. = before a command signifies that a u-name is mandatory.

4. (=) before a command signifies that a u-name is optional.

5. Otherwise no u-name is permitted.

6. Unless otherwise noted, the LIKE keyword is permitted for each command.

7. To exceed the listed keyword range values, use the code-word NO-LIMITS under the DIAGNOSTIC command.

8. "CWF" refers to Custom Weighting Factors.

9. An arrow $(\rightarrow)$ indicates a keyword used only for daylighting calculation 


\section{LOADS SUMMARY}

INPUT LOADS Required for Loads input

Note: Maximum total INPUT plus PARAMETRIC-INPUT plus LIBRARY-INPUT commands is 100 INPUT-UNITS(ENGLISH;ENGLISH,METRIC) OUTPUT-UNITS(ENGLISH;ENGLISH,METRIC)

[Caution: Defaults to ENGLISH at each subprogram; if all-metric run is desired, METRIC must be specified at each level.]

\section{PARAMETRIC-INPUT LOADS}

INPUT-UNITS(ENGLISH;ENGLISH,METRIC)

OUTPUT-UNITS(ENGLISH;ENGLISH,METRIC)

Replaces INPUT LOADS for parametric run.

[Caution: Defaulis to ENGLISH at each subprogram; if a metric run is desired, METRIC must be specified at

beginning of the parametric run.]

\section{LIBRARY-INPUT LOADS} INPUT-UNITS(ENGLISH;ENGLISH,METRIC)

Replaces INPUT LOADS for library run

TITLE(5) LINE- $n$ *Up to 40 characters enclosed by asterisks*

where $n=1,2, \ldots, 5$

Note: In SYSTEMS, PLANT, and ECONOMICS, lines may be replaced, up to an overall total of 5.

Also, any particular LINE- $n$ may be substituted for lines input in LOADS by using TITLE command

followed by LINE- $n$ *changed text*, where $n$ is the line to be changed.

\section{ABORT(ERRORS;ERRORS, WARNINGS,CAUTIONS)}

DIAGNOSTIC(LIST) takes up to six optional code-words

WARNINGS;ERRORS,WARNINGS,CAUTIONS,DEFAULTS,COMMENTS

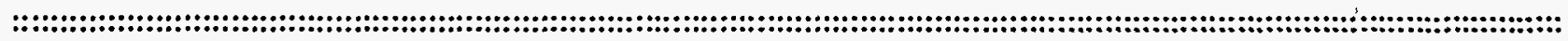

(default;options)

ECHO;ECHO,NO-ECHO

SINGLE-SPACED;SINGLE-SPACED,DOUBLE-SPACED

LIMITS;LIMTS, NO-LIMITS

No listing of library;LIBRARY-CONTENTS $\dagger$

$\dagger$ To be used only when user wishes to list the contents of the materials, walls, and weighting factors library. Warning: Use of this code-word may produce many pages of output.

RUN-PERIOD(1) Required for LOADS input

month day year THRU month day year (e.g., JAN 11985 THRU DEC 31 1985)

Remember: Beginning and ending dates must be within a calendar year

Code-word for month is the first three letters of month name

A maximum of 15 THRU's allowed 


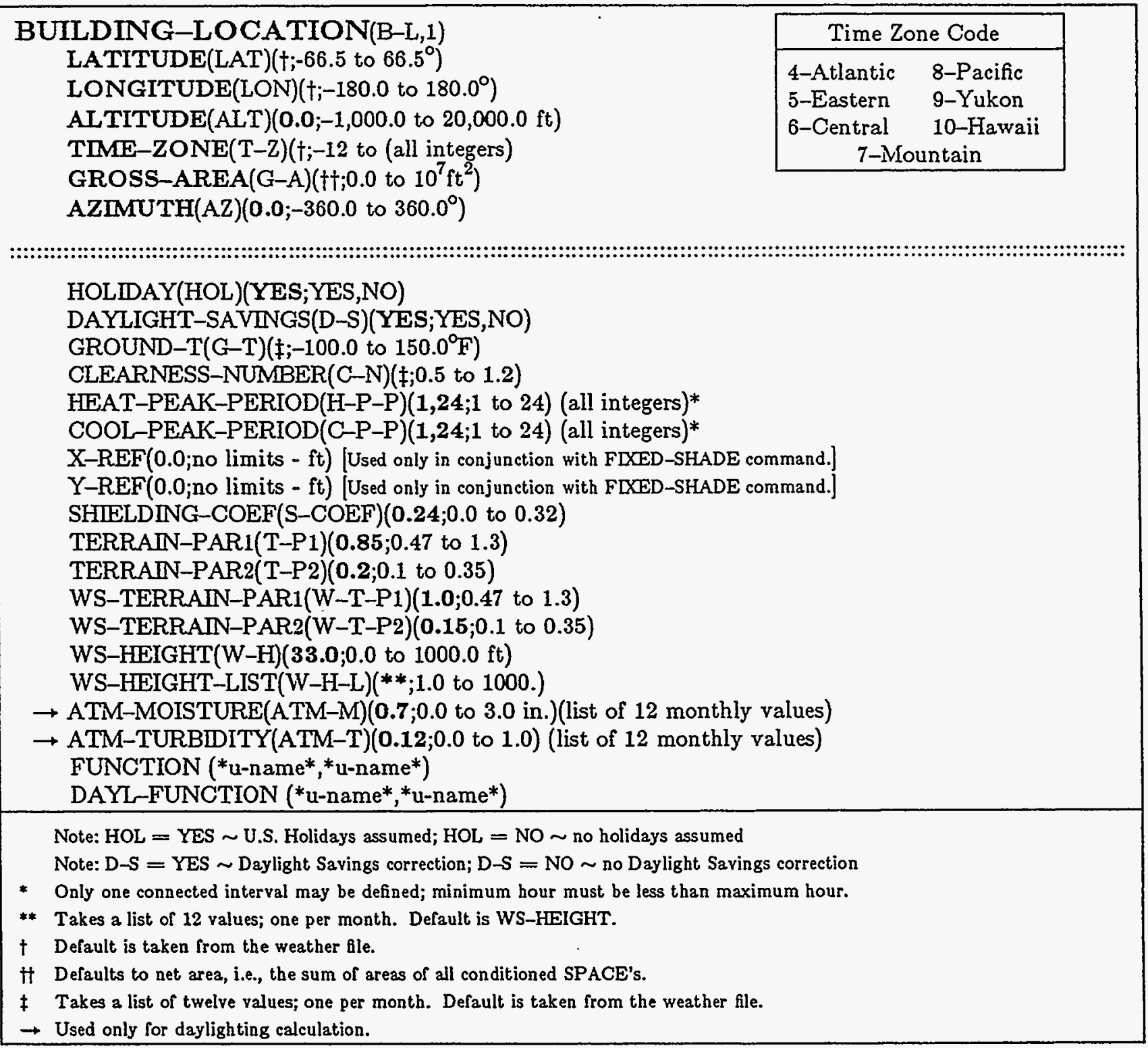

- ALT-HOLIDAYS(1)(A-H) [allows user to input non-US holidays] month day month day month day month day ... ..

Only one command is allowed per loads input. It does not allow a u-name. It has no keywords; instead, it takes month day like the RUN-PERIOD command. Up to 40 month-day pairs may be input. Use of ALT-HOLDAYS replaces all the standard holidays hardwired into DOE-2. Month is JAN, FEB, MAR, APR, MAY, JUN, JUL, AUG, SEP, OCT, NOV, or DEC (a code-word) and day is an integer (1-31). The holidays may be entered in any order.

PARAMETER(DEFINE, $\dagger$ )

U-NAME = VALUE,U-NAME = VALUE, etc. Note: for parametric runs

† A maximum of 50 commands in each LOADS, SYSTEMS,

PLANT and ECONOMICS with a total of 50 parameters defined. 
SET-DEFAULT(SET, $\dagger$ )

- FOR command name

KEYWORD $=$ value, IEYWORD = value, etc.

I t A maximum of 100 SET-DEFAULT commands may be used in each of LOADS, SYSTEMS, PLANT and ECONOMICS.)

$\Leftrightarrow$ DESIGN-DAY(D-D,3) Note: If this command is used, then all keywords are required CLEARNESS(CL)(一;0.5 to 1.2$)$

CLOUD-AMOUNT(C-A)(-;0 to 10)

CLOUD-TYPE(C-T) $(-; 0 \text { or } 1 \text { or } 2)^{* *}$

DEWPT-HI(DP-H) (-; 100 to $\left.200^{\circ} \mathrm{F}\right)$

DEWPT-LO(DP-L)(-; -100 to $\left.200^{\circ} \mathrm{F}\right)$

DHOUR-HI(DH-H) $(-; 1$ to 24$)$

DHOUR-LO(DH-L)(-;1 to 24)

DRYBULB-HI(DB-H) (-; -100 to $\left.200^{\circ} \mathrm{F}\right)$

DRYBULB-LO(DB-L) $\left(-;-100\right.$ to $\left.200^{\circ} \mathrm{F}\right)$

GROUND-T(G-T) $\left(-;-100\right.$ to $\left.200^{\circ} \mathrm{F}\right)$

HOUR-HI(H-H)(-;1 to 24)

HOUR-LO(H-L)(一; 1 to 24)

WIND-DIR(W-D)(-;0 to 15)*

WIND-SPEED(W-S $)(-; 0.0$ to $200.0 \mathrm{kts})$

* $0=$ North; $4=$ East; $8=$ South; $12=$ West

** $0=$ Cirrus or Cirrostratus; $1=$ Stratus; $2=$ all other cloud types

\section{$=$ DAY-SCHEDULE(D-SCH,300)}

(see example below)

Note: All 24 hours must be accounted for

In its simplest form, the input for DAY-SCHEDULE takes the form:

U-NAME = DAY-SCHEDULE (hours covered) (values for each hour) ..

For example, for weekdays:

$$
\text { LTG-1 = DAY-SCHEDULE }(1,24)(0,0,0,0,0,0,0,0, .3, .6, .8,1,1,1,1,1,1,1,0,0,0,0,0,0) \quad . .
$$

Optionally, this can be shortened by writing:

$$
\text { LTG-1 }=\text { DAY-SCHEDULE }(1,8)(0)(9,11)(.3, .6, .8)(12,18)(1)(19,24)(0) \quad . .
$$

For week-ends and holidays:

$$
\text { LTG-2 = DAY-SCFEDULE }(1,24)(0)
$$


$=$ WEEK-SCHEDULE(W-SCH,200)

(see example below)

Note: Code-word for days of week and holidays is first three letters of name.

ALL=Monday thru Sunday + Holidays; WEH=weekends + Holidays; and WD=weekdays

Note: Must preserve order of Monday, Tuesday, Wednesday, Thursday, Friday, Saturday, Sunday, Holiday

Note: All days of week + Holiday must be accounted lor

In its simplest form, the input for WEEK-SCHEDULE takes the form:

U-NAME = WEEK-SCHEDULE $(\dagger)$ (U-NAME of DAY-SCHEDULE referenced)

$\dagger$ days of week covered

Using the previously defined DAY-SCHEDULEs LTG-1 and LTG-2, the example can be carried forward with:

$$
\begin{array}{ll}
\text { NORMAL }=\text { WEEK-SCHEDULE } & \text { (MON,FRI) LTG-1 } \\
& \text { (SAT,HOL) LTG-2 .. } \\
\text { VACATION }=\text { WEEK-SCHEDULE } & \text { (ALL) LTG-2 .. }
\end{array}
$$

Optionally, NORMAL can be shortened to:

NORMAL = WEEK-SCHEDULE (WD) LTG-1 (WEH) LTG-2 ..

where (WD) stands for week-days and (WEH) for week-ends and holidays.

If Saturday is considered part of the normal week, you must write (MON,SAT) LTG-1 (SUN,HOL) LTG-2.

$=$ SCHEDULE(SCH,100) Note: LIKE keyword not allowed

(see example below)

Note: Every day of run period must be accounted for

Note: Code-word for month is first three letters of month name

Note: A maximum of 52 THRU's per command

In its simplest form, the input for SCHEDULE takes the form:

U-NAME =SCHEDULE(THRU $\uparrow)(U-N A M E$ of WEEK-SCHEDULE referenced) .• † calendar period covered

To finalize the example:

LIGHTS $=$ SCHEDULE

THRU JUN 10 NORMAL

THRU SEP 5 VACATION

THRU DEC 31 NORMAL ..

Alternatively, explicit use of DAY-SCHEDULE and WEEK-SCHEDULE can be bypassed by writing:

$\begin{array}{ll}\text { LIGHTS = SCHEDULE } & \text { THRU JUN } 10(\text { WD })(1,8)(0)(9,11)(.3, .6, .8)(12,18)(1)(19,24)(0)(\text { WEH })(1,24)(0) \\ & \text { THRU SEP } 5(\text { ALL })(1,24)(0) \\ & \text { THRU DEC } 31(\text { WD })(1,8)(0)(9,11)(.3, .6,8)(12,18)(1)(19,24)(0)(W E H)(1,24)(0) \ldots\end{array}$

$\bullet=$ Required keyword 
$=$ MATERLAL(MAT,128)

- THICKNESS(TH)(-;0.0 to 10.0 feet)

and

- CONDUCTIVITY(COND)(-;0.0 to $\left.30.0 \mathrm{Btu}-\mathrm{ft} / \mathrm{hr}-\mathrm{ft}{ }^{2}-{ }^{\circ} \mathrm{F}\right)$

and

- DENSITY(DENS)(-;0.0 to $\left.500.0 \mathrm{lb} / \mathrm{ft}^{3}\right)$

and

- SPECIFIC-HEAT(S-H)(一;0.0 to $\left.5.0 \mathrm{Btu} / \mathrm{lb}-{ }^{\circ} \mathrm{F}\right)$

or just RESISTANCE instead of all the above:

- RESISTANCE(RES)(-;0.0 to $\left.40.0 \mathrm{hr}-\mathrm{ft}^{2}-{ }^{\circ} \mathrm{F} / \mathrm{Btu}\right)$

Note: for materials data see Chapter 23 of the ASHRAE Hondbook of Fundamentals, 1985.

\section{$=$ CONSTRUCTION(CONS,64)}

- LAYERS(LA) u-name or code-word

or

- U-VALUE(U)(-;0.0 to $20.0 \mathrm{Btu} / \mathrm{hr}^{\left.-\mathrm{ft}^{2}-\mathrm{F}\right) \dagger}$

ABSORPTANCE(ABS)(0.7;0.0 to 1.0)[Not used for interior walls, underground walls, or underground foors]

ROUGHIESS(RO)(3;1 to 6)(all integers) [Not used for interior walls, underground walls, or underground loors]

[Values of ABSORPTANCE and ROUGHNESS are found in the following tables]

WALL-PARAMETERS(W-P) u-name [Required for Trombe walls and sunspaces with interior venting.]

$\dagger$ For interior surfaces, includes resistance of both air films;

for exterior surfaces, includes inside film resistance, but not outside film resistance.

$=$ LAYERS(LA,64) Note: LIKE keyword not allowed

- MATERLAL(MAT)

Note:Value must be a list of either the u-names of MATERIALs or code-words

from the Materials Library on p.118.

\section{THICKNESS(TH)}

Note: Must be specified if any thickness is different from those specified in MATERIAL commands or Materials Library. Order of list must correspond to list following MATERLALs INSIDE-FLM-RES(I-F-R)(0.68;0.0 to $\left.40.0 \mathrm{hr}-\mathrm{ft} \mathrm{t}^{2}-\mathrm{O} / \mathrm{F} / \mathrm{Btu}\right)$

Note: List materials (a maximum of 9) from outside to inside; do not specify inside or outside air film as a material 
Solar ABSORPTANCE for Various Exterior Surfaces (Clean)

\begin{tabular}{|c|c|c|c|}
\hline Material & $\begin{array}{l}\text { ABSORP } \\
\text { TANCE }\end{array}$ & Paint & $\begin{array}{l}\text { ABSORP- } \\
\text { TANCE }\end{array}$ \\
\hline Aluminum, polished reflector sheet & 0.12 & Aluminum paint & 0.40 \\
\hline Asphalt pavement, weathered & 0.82 & Black, flat & 0.95 \\
\hline Brick, buf, light & 0.55 & Black, lacquer & 0.92 \\
\hline Brick, red & 0.88 & Black, oil & 0.90 \\
\hline Brick, Stafford blue & 0.89 & Black, optical flat & 0.98 \\
\hline Brick, white glazed & 0.25 & Blue, azure lacquer & 0.88 \\
\hline Cement, uncolored asbestos & 0.75 & Blue, dark & 0.91 \\
\hline Cement, white asbestos & 0.61 & Blue, medium & 0.51 \\
\hline Concrete, black & 0.91 & Blue-gray, dark & 0.88 \\
\hline Concrete, brown & 0.85 & Brown, dark brown & 0.88 \\
\hline Concrete, uncolored & 0.65 & Brown lacquer & 0.79 \\
\hline Film, Mylar aluminized & 0.10 & Brown, medium & 0.84 \\
\hline Felt, bituminous & 0.88 & Brown, medium light & 0.80 \\
\hline Felt, bituminous, aluminized & 0.40 & Gray, dark & 0.91 \\
\hline Gravel & 0.29 & Gray, light oil & 0.75 \\
\hline Iron, white-on-galvanized & 0.26 & Green, lacquer & 0.79 \\
\hline Lab vapor deposited coatings & 0.02 & Green, Jacquer, dark & 0.88 \\
\hline Marble, white & 0.58 & Green, light & 0.47 \\
\hline Roof, white built-up & 0.50 & Green, medium dull & 0.59 \\
\hline Roofing, green & 0.86 & Green, medium Kelly & 0.51 \\
\hline Slate, blue-gray & 0.87 & Olive, dark drab & 0.89 \\
\hline Tin surface & 0.05 & Orange, medium & 0.58 \\
\hline \multirow[t]{7}{*}{ Wood, smooth } & 0.78 & Red, oil & 0.74 \\
\hline & & Rust, medium & 0.78 \\
\hline & & Silver & 0.25 \\
\hline & & White, gloss & 0.25 \\
\hline & & White, lacquer & 0.21 \\
\hline & & White, semi-gloss & 0.30 \\
\hline & & Yellow & 0.57 \\
\hline
\end{tabular}

\begin{tabular}{|llc|}
\hline \multicolumn{3}{|c|}{ ROUGHNESS Code for Exterior Surface Finish } \\
Wall & Roof & $\begin{array}{c}\text { Code- } \\
\text { number }\end{array}$ \\
\hline Stucco & Wood shingles or & 1 \\
& Built-up roof w/stones & 2 \\
Brick or Plaster & & $3^{*}$ \\
Concrete (poured) & Asphalt shingles & 4 \\
Clear pine & Metal & 5 \\
Smooth plaster & & 6 \\
Glass or Paint on pine & & \\
& & \\
\hline * 3 is the default value & \\
\hline
\end{tabular}




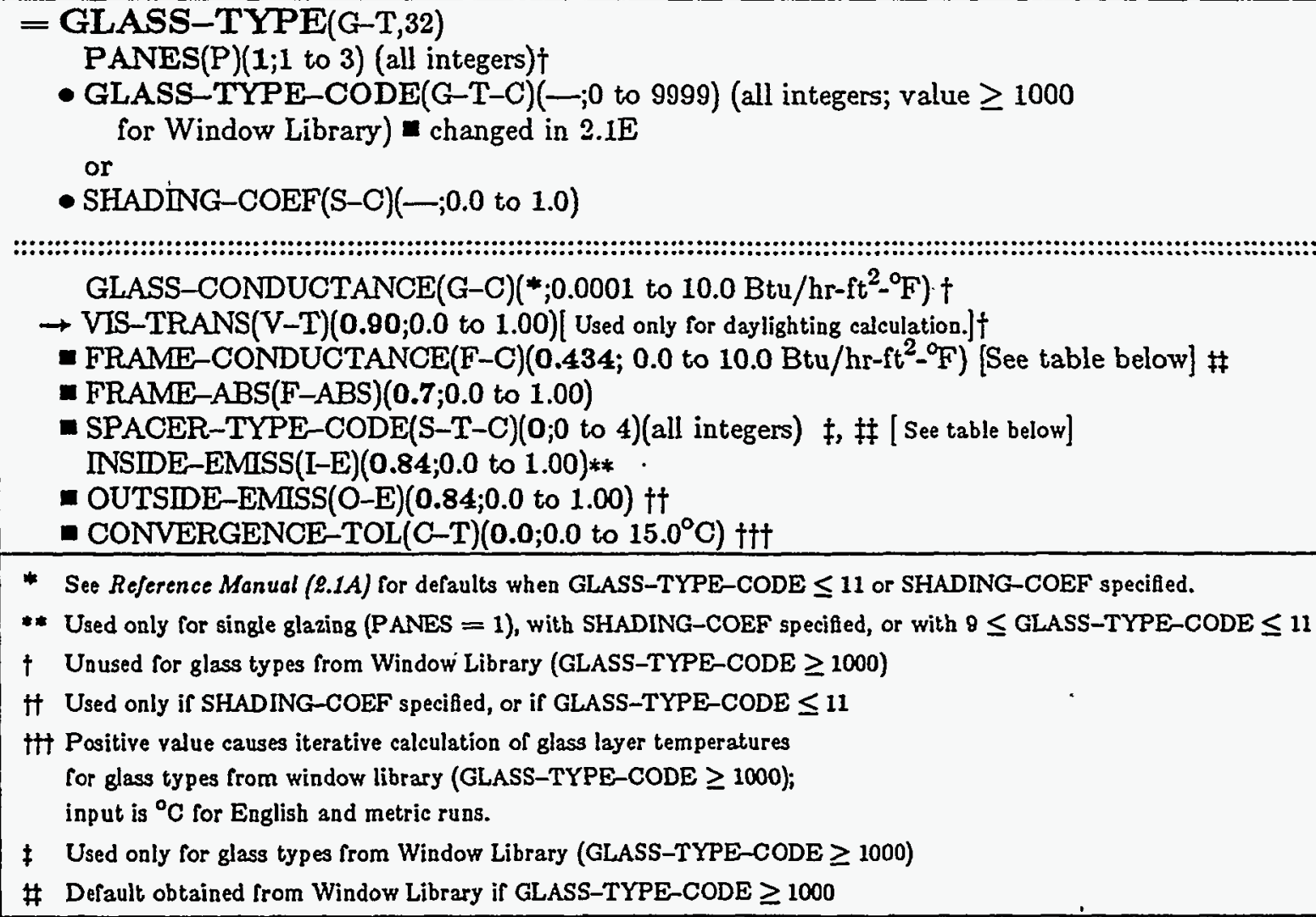

* See Reference Manual (2.1A) for defaults when GLASS-TYPE-CODE $\leq 11$ or SHADING-COEF specifled.

* Used only for single glazing (PANES = 1), with SHADING-COEF specifed, or with $8 \leq$ GLASS-TYPE-CODE $\leq 11$

$\dagger$ Unused for glass types from Window Library (GLASS-TYPE-CODE $\geq 1000$ )

if Used only if SHADING-COEF specifed, or if GLASS-TYPE-CODE $\leq 11$

ttt Positive value causes iterative calculation of glass layer temperatures for glass types from window library (GLASS-TYPE-CODE $\geq 1000$ ); input is ${ }^{\circ} \mathrm{C}$ for English and metric runs.

¥ Used only for glass types from Window Library (GLASS-TYPE-CODE $\geq 1000$ )

\# Default obtained Irom Window Library if GLASS-TYPE-CODE $\geq 1000$

\begin{tabular}{|lcc|}
\hline \multicolumn{3}{|c|}{ Conductance of Typical Frame Constructions $\left(\mathrm{Btu} / \mathrm{ft}^{2}-\mathrm{F}-\mathrm{h}\right)$} \\
Frame Type & $\begin{array}{c}\text { FRAME- } \\
\text { CONDUCTANCE } \\
\text { (excludes OA film) }\end{array}$ & $\begin{array}{c}\text { U-value } \\
\text { (includes OA film) }\end{array}$ \\
\hline Thermally unbroken aluminum & 3.037 & 1.90 \\
Thermally broken aluminum & 1.245 & 1.00 \\
External flush glazed aluminum & 0.812 & 0.70 \\
Wood with or without cladding & 0.434 & 0.40 \\
Vinyl & 0.319 & 0.30 \\
* FRAME-CONDUCTANCE $=\left\lfloor\left(\mathrm{U}_{\text {-value }}{ }^{-1}-0.197\right]^{-1}\right.$ & \\
\hline
\end{tabular}

\begin{tabular}{|ll|}
\hline \multicolumn{2}{|c|}{ Between-Glass Spacers } \\
SPACER-TYPE-CODE & Spacer type \\
\hline 0 & Spacer is taken from Window Library \\
1 (default) & Aluminum \\
2 & Glass \\
3 & Butyl/Metal \\
4 & Wood or Fibreglas \\
\hline
\end{tabular}


(=) BUILDING-SHADE(B-S,64)

$\mathrm{X}(0.0$; no limits - $\mathrm{ft})$

$\mathrm{Y}(0.0$;no limits $-\mathrm{ft})$

$\mathrm{Z}(0.0$; no limits - $\mathrm{ft})$

- HEIGHT(H)(-;0.0 to $2,000.0 \mathrm{ft})$

- WIDTH(W) $(-; 0.0$ to $2,000.0 \mathrm{ft})$

AZIMUTH(AZ)(0.0;-360.0 to $\left.360.0^{\circ}\right)$

$\operatorname{TLT}\left(80.0 ; 0.0\right.$ to $\left.180.0^{\circ}\right)$

TRANSMITTANCE(TR)(0.0;0.0 to 1.0 ) [Daylighting calculation assumes TRANSMITTANCE $=0$ ]

SHADE-SCHEDULE(S-SCH) u-namef [Daylighting calculation assumes TRANSMITTANCE $=0$ ]

SHADE-VIS-REFL(S-V-R)(0.5;0.0001 to 1.0) [Used only for daylighting calculation.

SHADE-GND-REFL(S-G-R)(0.2;0.0001 to 1.0) [Used only for daylighting calculation.

$\dagger$ Used only to simulate variable exterior shading devices; use of this keyword overrides TRANSMITTANCE value.

Note: $X, Y, Z$ are coordinates of lower left hand corner of the shading surface in the building coordinate

system when viewed from the tip of the outwardly drawn normal

$(\Rightarrow)$ FIXED-SHADE $(F-S, 33)$

$\mathrm{X}-\operatorname{REF}(0.0 ;$ no limits - $\mathrm{ft}$ )

$\mathrm{Y}-\mathrm{REF}(0.0$; no limits - $\mathrm{ft})$

Z-REF(0.0; no limits - $\mathrm{ft})$

- HEIGHT(H)(-;0.0 to $2,000.0 \mathrm{ft})$

- WDTH(W) $(-; 0.0$ to $2,000.0 \mathrm{ft})$

AZIMUTH(AZ) $\left(0.0 ;-360.0\right.$ to $\left.360.0^{\circ}\right)$

$\operatorname{TITT}\left(80.0 ; 0.0\right.$ to $\left.180.0^{\circ}\right)$

TRANSMITTANCE(TR)(0.0;0.0 to 1.0) [Daylighting calculation assumes TRANSMTTTANCE $=0$.]

SHADE-SCHEDULE(S-SCH) u-name [ Daylighting calculation assumes TRANSMITTANCE $=0$.]

SHADE-VIS-REFL(S-V-R) $(0.5 ; 0.0001$ to 1.0 ) [ Used only for daylighting calculation.]

SHADE-GND-REFL(S-G-R)(0.2;0.0001 to 1.0) [ Used only for daylighting calculation.]

Note: FIXED-SHADE command used only for stationary shading surfaces which are NOT rotated or translated with the building

$\dagger$ Used only to simulate variable exterior shading devices; use of this keyword overrides TRANSMITTANCE value.

Note: $X, Y, Z$ are coordinates of lower left hand corner of the shading surface in the building coordinate

system when viewed from the tip of the outwardly drawn normal 
$=$ WALL-PARAMETERS(W-P,4)

- FOR(—;TROMBE-WALL-V,TROMBE-WALL-NV,INTERIOR-WALL)

EMISSIVITY(EM)(0.93;0.0 to 1.0)

CHANNEL-WIDTH(C-W $)(* ; 0.0$ to $1.0 \mathrm{ft})$ * Required for TROMBE-WALL.

LOWER-VENT-AREA(L-V-A) $\left(t ; 0.0\right.$ to $\left.100 \mathrm{ft}^{2}\right)$

UPPER-VENT-AREA(U-V-A) $\left(\dagger ; 0.0\right.$ to $\left.100 \mathrm{ft}^{2}\right)$

VERT-VENT-SEP(V-V-S) $(\dagger ; 0.0$ to $20.0 \mathrm{ft})$

AIR-FLOW-TYPE(A-F-T)(NO-AIR-FLOW;NO-AIR-FLOW,FORCED-RECIRC,

FORCED-OA-PREHT,FREE-RECIRC,FREE-DOORWAY)**

AIR-FLOW-RATE(A-F-R)(tt;0.0 to $\left.999999.00 \mathrm{ft}^{3} / \mathrm{min}\right)$

AIR-FLOW-CTRL-DT(A-F-C-DT)(3.0;-100.0 to 50.0 $\mathrm{F}) \dot{\ddagger}^{* *}$

FAN-KW(F-IKW) $(0.00003 ; 0.0$ to $0.01 \mathrm{~kW} / \mathrm{cfm}) \mathrm{ff}^{* *}$

DOORWAY-H(D-H)( $\ddagger \ddagger 0.0$ to $8.0 \mathrm{ft})^{* *}$

DOORWAY-W(D-W) $(\$ \ddagger ; 0.0 \text { to } 99.0 \mathrm{ft})^{* *}$

** Used only for INTERIOR-WALl.

$\dagger$ Required for TROMBE-WALL-V; unused for TROMBE-WALL-NV.

For sunspaces, required if AIR-FLOW-TYPE = FREE-RECIRC; unused for others.

if Used only if AIR-FLOW-TYPE = FORCED-RECIRC or FORCED-OA-PREHT.

AIR-FLOW-RATE is required.

\$ Defaults to $-100.0^{\circ}$ for AIR-FLOW-TYPE = FORCED-OA-PREHT.

\# Required and used only if AIR-FLOW-TYPE = FREE-DOORWAY. 
$=$ SPACE-CONDITIONS(S-C,50) |Continued on the next page|

PEOPLE-SCHEDULE(P-SCH) u-name

NUMBER-OF-PEOPLE(N-O-P $)(0.0 ; 0.0$ to 10000.0)

AREA/PERSON(A/P)(100.0;0.0 to $\left.10,000.0 \mathrm{ft}^{2}\right)$ [Used only if NUMBER-OF-PEOPLE not specified]

PEOPLE-HEAT-GAIN(P-H-G)(0.0;350.0 to 2,000.0 Btu/hr-pers) $\dagger$

or

PEOPLE-HG-LAT(P-H-L)(0.0;0.0 to $2,000.0 \mathrm{Btu} / \mathrm{hr}-\mathrm{pers}) \dagger$

and

PEOPLE-HG-SENS(P-H-S)(0.0;0.0 to 2,000.0 Btu/hr-pers $) \dagger$

LIGHTING-SCHEDULE(L-SCH) u-name

LIGHTING-TYPE(L-T)(SUS-FLUOR; Options are: SUS-FLUOR,

REC-FLUOR-RV, REC-FLUOR-RSV, REC-FLUOR-NV, and INCAND.)

LIGHTING-W/SQFT $\left(0.0 ; 0.0\right.$ to $10.0 \mathrm{~W} / \mathrm{ft}^{2}$ ) [ If both specified, contribution is added] or

LIGHTING-KW(L $-\mathrm{KW})(0.0 ; 0.0$ to $200.0 \mathrm{~kW})$ [ If both specified, contribution is added.]

LIGHT-TO-SPACE(L-T-S $)(* ; 0.0$ to 1.0$)$

LIGHT-TO-OTHER(L-T-O) $(* ; 0.0$ to 1.0$)$

LIGHT-HEAT-TO(L-H-T) u-name of space [ Required if LIGHT-TO-OTHER > 0.]

LIGHT-TO-RETURN(L-T-R) $(* ; 0.0$ to 1.0$)$

LIGHT-RAD-FRAC(L-R-F)(*;0.0 to 1.0$)$ (list of two)

TASK-LIGHT-SCH(T-L-SCH) u-name

TASK-LT-W/SQFT(T-L-W)(0.0;0.0 to $10.0 \mathrm{~W} / \mathrm{ft}^{2}$ ) [ If both specified, contribution is added.] or

TASK-LIGHTING-IKW(T-L-KW) $(0.0 ; 0.0$ to $200.0 \mathrm{~kW})$ [ If both specified, contribution is added.]

EQUIP-SCHEDULE(E-SCH) u-name

EQUIPMENT-W/SQFT(E-W)(0.0;0.0 to $100.0 \mathrm{~W} / \mathrm{ft}^{2}$ ) [ If both specified, contribution is added] or

EQUIPMENT-KW(E-KW)(0.0;0.0 to $200.0 \mathrm{~kW})$ [ If both specified, contribution is added.]

EQUIP-SENSIBLE(E-S)(1.0;0.0 to 1.0$)$

EQUIP-LATENT(E-L)(0.0;0.0 to 1.0)

SOURCE-SCHEDULE(S-SCH) u-name

SOURCE-TYPE(S-T)(GAS;GAS,ELECTRIC,HOT-WATER,PROCESS)

SOURCE-BTU/HR(S-B)(0.0;-1,000,000.0 to $1,000,000.0 \mathrm{Btu} / \mathrm{hr})$

SOURCE-SENSIBLE(S-S)(1.0;-1.0 to 1.0)

SOURCE-LATENT(S-L)(0.0;0.0 to 1.0$)$

TEMPERATURE(T)((70.0);0.0 to $\left.120.0^{\circ} \mathrm{F}\right)$ (list of 1 )

WEIGHTING-FACTOR(W-F) [Space weighting factor u-name; 8 or less alphanumeric characters] $\dagger \dagger$

or

FLOOR-WEIGHT(F-W)(70.0;0.0 to $\left.200.0 \mathrm{lb} / \mathrm{ft}^{2}\right)+\dagger$, t†

FURNITURE-TYPE(F-TYPE)(HEAVY;LIGHT,HEAVY)[ Used only when CWF are to be calculated.] FURN-FRACTION(F-F)(0.0;0.0 to 1.0)[ Used only when CWF are to be calculated.]

FURN-WEIGHT(F-WGT)(0.0;0.0 to $\left.300.0 \mathrm{lb} / \mathrm{ft}^{2}\right)[$ Used only when CWF are to be calculated.]

- See the following "Default Table for LIGHTING-TYPEs".

$\dagger$ If no value is input, there is no contribution from people. If all are specified, the contribution is cumulative.

\# If neither is specified, default value for FLOOR-WEIGHT is used. WEIGHTING-FACTOR

is required for Custom Weighting Factor (CWF) library creation run; i.e., a LIBRARY-INPUT LOADS run.

H† For standard ASHRAE weighting factors, $30=$ light, $70=$ medium, $130=$ heavy.

For automatic calculation of CWF, specify FLOOR-WEIGHT $=0$. 
$=$ SPACE-CONDITIONS $(\mathrm{S}-\mathrm{C}, 50)$ [Continued]

INF-SCHEDULE(I-SCH) u-name

INF-METHOD(I-IM)(NONE;NONE,CRACK,AIR-CHANGE,RESIDENTIAL,S-G)

AIR-CHANGES/HR(A-C)(0.0;0.0 to 30.0) [ If both specified, contribution is added.]

or

INF-CFM/SQFT(I-CFM)(0.0;0.0 to $\left.20.0 \mathrm{cfm} / \mathrm{ft}^{2}\right)$ [ Ir both specified, contribution is added.]

ZONE-TYPE(Z-TYPE)(CONDITIONED;CONDITIONED,UNCONDITIONED,PLENUM)

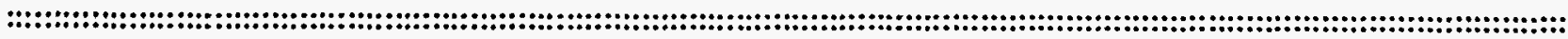

RES-INF-COEF(R-I-C)(0.252,0.0251,0.0084;0.0 to 20.0, mixed units)

NEUTRAL-ZONE-HT(N-Z-H)(0.0;no limits - $\mathrm{ft})$

HOR-LEAK-FRAC(H-L-F)(0.4;0.0 to 1.0$)$

NEUTRAI-LEVEL(N-L)(0.5;0.0 to 1.0$)$

FRAC-LEAK-AREA(F-L-A)(0.0005;0.0 to 1.0$)$

$\rightarrow$ DAYLIGHTING(DAY)(NO;NO,YES)

$\rightarrow$ LIGHT-REF-POINT1(L-R-P1)(-,-,2.5; no limits-ft)(list of 3)[Required for daylighting cale.]

$\rightarrow$ LIGHT-REF-POINT2(L-R-P2)(-, -,2.5;no limits-ft)(list of 3 )

$\rightarrow$ ZONE-FRACTION1(Z-F1)(1.0;0.0 to 1.0$)$

$\rightarrow$ ZONE-FRACTION2(Z-F2)(-;0.0 to 1.0)[Required if LIGHT-REF-POINT2 is specified.

If ZONE-FRACTION2 is specified, (ZONE-FRACTION1) + (ZONE-FRACTION2) should be $\leq 1.0$.)

$\rightarrow$ LIGHT-SET-POINT1(L-S-P1)(50.0;1.0 to 500.0 footcandles)

$\rightarrow$ LIGHT-SET-POINT2(L-S-P2)(50.0;1.0 to 500.0 footcandles)

$\rightarrow$ LIGHT-CTRL-TYPEI(L-C-T1)(CONTINUOUS;CONTINUOUS,STEPPED)

$\rightarrow$ LIGHT-CTRL-TYPE2(L-C-T2)(CONTINUOUS;CONTINUOUS,STEPPED)

$\rightarrow$ MIN-POWER-FRAC (M-P-F $)(0.3 ; 0.0$ to 1.0$)$

$\rightarrow$ MIN-LIGHT-FRAC(M-L-F)(0.2;0.0 to 1.0$)$

$\rightarrow$ LIGHT-CTRL-STEPS(L-C-S)(3.0;1.0 to 20.0)

$\rightarrow$ LIGHT-CTRL-PROB(L-C-P) $(1.0 ; 0.0$ to 1.0$)$

$\rightarrow$ DAYLIGHT-REP-SCH(D-R-SCH) u-name

$\rightarrow$ MAX-GLARE(M-G)(100.0;0.0 to 100.0)

$\rightarrow$ VIEW-AZIMUTH(V-AZ) $\left(\dagger+;-360.0\right.$ to $\left.360.0^{\circ}\right)[t+$ Default=direction parallel to 1 st window in space.] SUNSPACE(SUNSP)(NO;NO,YES)

$\rightarrow$ Used only for daylighting calculation.

\begin{tabular}{|l|c|c|c|c|c|}
\hline \multicolumn{7}{|c|}{ Default Table for LIGHTING-TYPEs } \\
\hline & $\begin{array}{c}\text { SUS- } \\
\text { FLUOR }\end{array}$ & $\begin{array}{c}\text { REC- } \\
\text { FLUOR-RV }\end{array}$ & $\begin{array}{c}\text { REC- } \\
\text { FLUOR-RSV }\end{array}$ & INCAND & $\begin{array}{c}\text { REC- } \\
\text { FLUOR-NV }\end{array}$ \\
\hline LIGHT-TO-SPACE & 1.0 & 0.8 & 0.8 & 1.0 & 1.0 \\
LIGHT-TO-OTHER & 0.0 & 0.0 & 0.0 & 0.0 & 0.0 \\
LIGHT-TO-RETURN & $*$ & $*$ & $*$ & $*$ & $*$ \\
LIGHT-RAD-FRAC & & 0.59 & 0.19 & 0.71 & 0.67 \\
$\quad$ in this space & 0.67 & 0.09 & 0.09 & 1.0 & 0.9 \\
in other space & 1.0 & 0.0 & \\
\hline *Deraults to 1.0 minus LIGHT-TO-SPACE minus LIGHT-TO-OTHER.
\end{tabular}

- = Required keyword

$-17-$

= Added/changed in 2.1E 


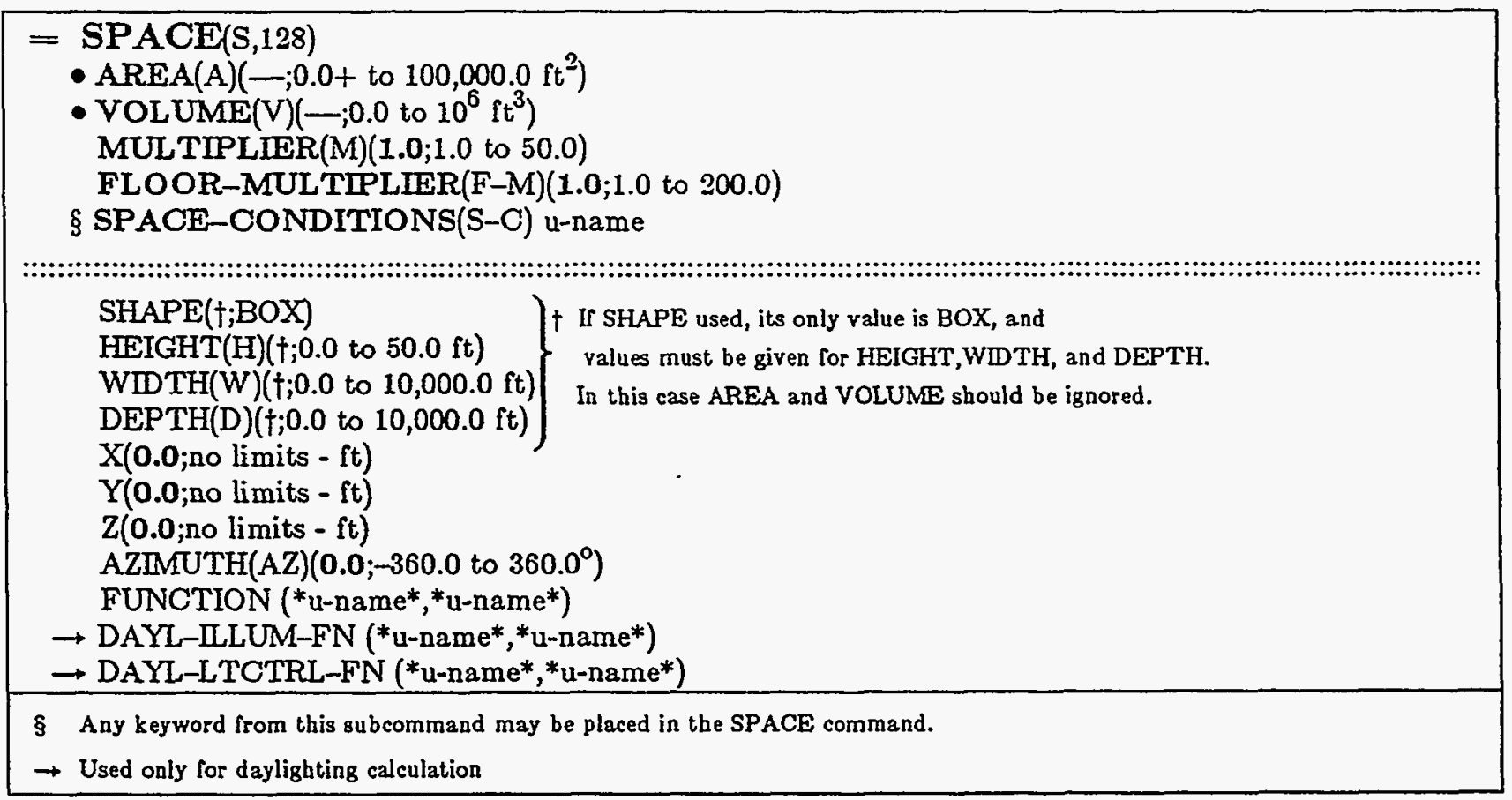

\begin{tabular}{|c|c|c|c|c|c|c|}
\hline \multicolumn{7}{|c|}{$\begin{array}{l}\text { Applicability Table of SPACE-CONDITIONS Infilt } \\
\text { Different Infiltration Meth }\end{array}$} \\
\hline \multirow[b]{2}{*}{ Keyword } & \multicolumn{6}{|c|}{ INF-METHOD } \\
\hline & NONE & $\begin{array}{l}\text { AIR } \\
\text { With Wind } \\
\text { Correction }\end{array}$ & $\begin{array}{l}\text { ANGE } \\
\text { Without Wind } \\
\text { Correction }\end{array}$ & GRACK & $\begin{array}{c}\text { RESI- } \\
\text { DENTIAI }\end{array}$ & S-G \\
\hline $\begin{array}{l}\text { AIR-CHANGES/HR } \\
\text { FRAC-LEAK-AREA } \\
\text { HOR-LEAK-FRAC } \\
\text { INF-CFM-SQFT } \\
\text { INF-COEF* } \\
\text { INF-SCHEDULE† } \\
\text { NEUTRAL-LEVEL } \\
\text { NEUTRAL-ZONE-HT } \\
\text { RES-INF-COEF }\end{array}$ & $\begin{array}{l}\text { not used } \\
\text { not used } \\
\text { not used } \\
\text { not used } \\
\text { not used } \\
\text { not used } \\
\text { not used } \\
\text { not used } \\
\text { not used }\end{array}$ & $\begin{array}{c}\text { requised } \\
\text { not used } \\
\text { not used } \\
\text { not used } \\
\text { not used } \\
\text { used } \\
\text { not used } \\
\text { not used } \\
\text { not used }\end{array}$ & $\begin{array}{l}\text { not used } \\
\text { not used } \\
\text { not used } \\
\text { required } \\
\text { not used } \\
\text { used } \\
\text { not used } \\
\text { not used } \\
\text { not used }\end{array}$ & $\begin{array}{l}\text { not used } \\
\text { not used } \\
\text { not used } \\
\text { not used } \\
\text { required } \\
\text { used } \\
\text { not used } \\
\text { required } \\
\text { not used }\end{array}$ & $\begin{array}{l}\text { not used } \\
\text { not used } \\
\text { not used } \\
\text { not used } \\
\text { not used } \\
\text { used } \\
\text { not used } \\
\text { not used } \\
\text { used }\end{array}$ & $\begin{array}{l}\text { not used } \\
\text { used } \neq \\
\text { used } \ddagger \\
\text { not used } \\
\text { not used } \\
\text { used } \\
\text { used } \neq \\
\text { not used } \\
\text { not used }\end{array}$ \\
\hline \multicolumn{7}{|c|}{ † If not specified, always on $\ddagger$ If not specified, takes default value } \\
\hline \multicolumn{7}{|c|}{$\begin{array}{l}\text { This keyword is input under the EXTERIOR-WALL, DOOR, and WINDOW commands. Note: For } \\
\text { INF-METHOD= RESDENTLAL, wind and temperature dependence is given through the RES-INF-COEF key- } \\
\text { word. }\end{array}$} \\
\hline
\end{tabular}

- $=$ Required keyword 


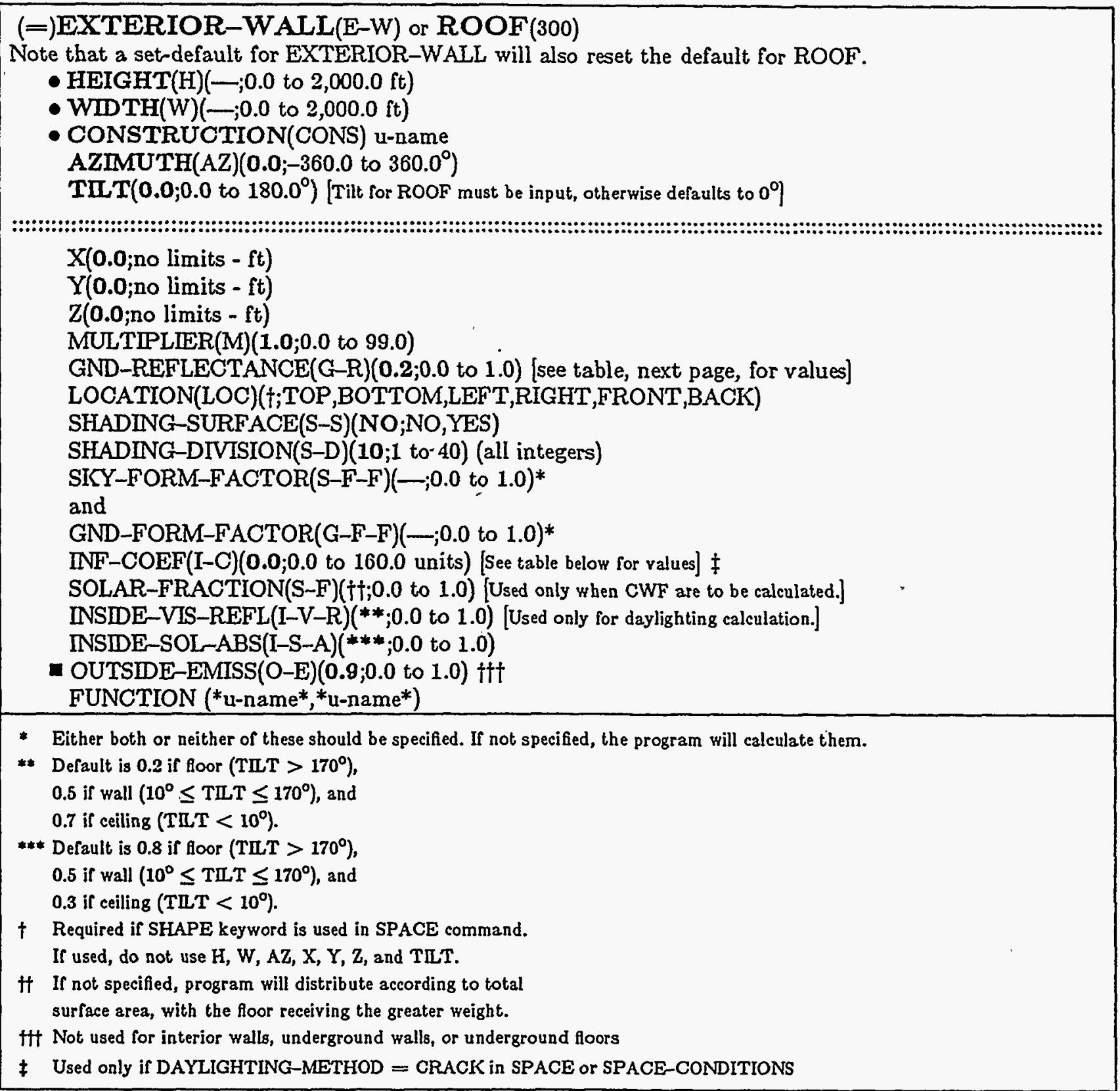

\begin{tabular}{|c|c|c|}
\hline \multicolumn{3}{|c|}{ Exterior Wall Infiltration Coefficients } \\
\hline Construction of Wall & $\frac{\mathrm{cfh}}{\mathrm{ft}_{\mathrm{wall}}^{2}}$ & INF-COEF \\
\hline $13^{\prime \prime}$ brick w/plastered surface & $(0.01)$ & 0.002 \\
\hline $13^{\prime \prime}$ brick, furring, lath, plaster & $(0.03)$ & 0.005 \\
\hline Frame wall, lath and plaster & $(0.09)$ & 0.016 \\
\hline $8-1 / 2^{\prime \prime}$ brick, plain & $(5.0)$ & 0.915 \\
\hline $16^{11}$ shingles on shiplap $w /$ building paper & $(0.5)$ & 0.092 \\
\hline $16 "$ shingles on shiplap & $(8.0)$ & 1.465 \\
\hline $16^{\prime \prime}$ shingles on $1 \times 4$ boards on $5^{\prime \prime}$ center & $(40.01)$ & 7.324 \\
\hline
\end{tabular}




\begin{tabular}{|lc|ll|}
\hline \multicolumn{4}{|c|}{ Typical Ground Reflectance Values } \\
\hline Surface & GND-REFLECTANCE & & \\
\hline Asphalt (Paved) & 0.18 & Field (Wheat) & 0.07 \\
Concrete (Bituminous) & 0.10 & Grass (Dry) & 0.24 \\
Concrete (Light-Colored) & 0.32 & Ocean & 0.05 \\
Concrete (Old) & 0.22 & Rock (Crushed) Surface & 0.20 \\
Field (Green) & $0.12-0.25$ & Soil (Dark) & 0.08 \\
\hline
\end{tabular}

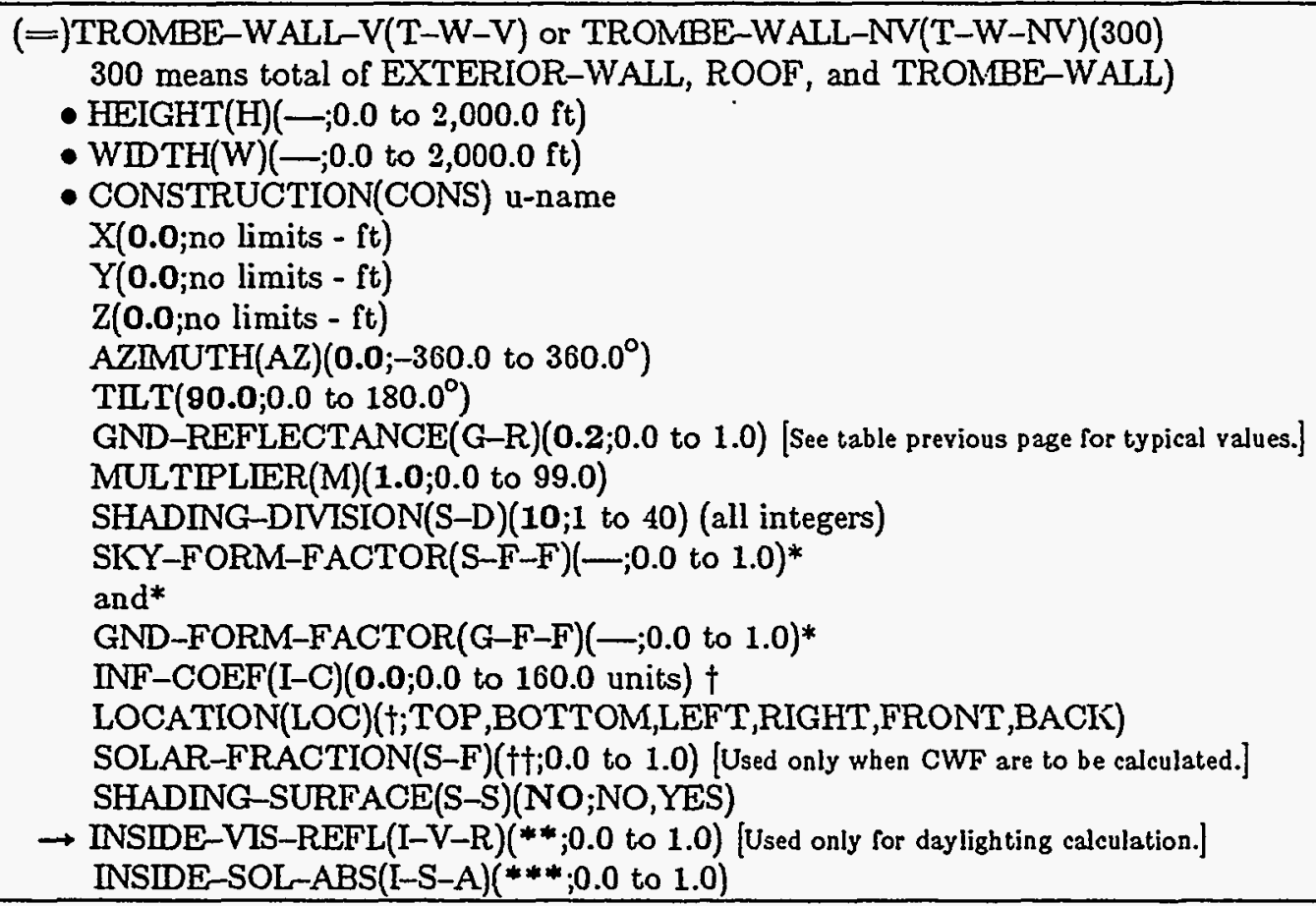

- Either both or neither of these should be specifed.

If not specified, the program will calculate them.

** Default is 0.2 if floor (TLT $>170^{\circ}$ ), 0.5 if wall $\left(10 \leq \mathrm{TILT} \leq 170^{\circ}\right)$, and 0.7 if ceiling ( $\mathrm{TLT}<10^{\circ}$ ).

*** Default is 0.8 if foor (TLT $>170^{\circ}$ ), 0.5 if wall $\left(10^{\circ} \leq \mathrm{TIT} \leq 170^{\circ}\right)$, and 0.3 if ceiling ( $\mathrm{THT} T 10^{\circ}$ ).

$\dagger$ Required if SHAPE keyword is used in SPACE command. If used, do not use $H, W, A Z, X, Y, Z$, and TILT.

if If not specified, program will distribute according to total surface ares, with the floor receiving the greater weight. 
$(=)$ WINDOW(WI)(200) |Continued on the next page|

- HEIGHT(H) $(-; 0.0001$ to $40.0 \mathrm{ft})$

- WIDTH(W) $(-; 0.0001$ to $1000.0 \mathrm{ft})$

- GLASS-TYPE(G-T) u-name

$X(0.0 ; 0.0$ to $2,000.0 \mathrm{ft})$

$\mathrm{Y}(0.0 ; 0.0$ to $2,000.0 \mathrm{ft})$

SETBACK(SETB) $(0.0 ; 0.0$ to $10.0 \mathrm{ft}$ ) [Unused for interior windows]

MULTIPLIER(M)(1.0;0.0 to 99.0$)$

- FRAME-WIDTH(FR-W)(0.0;0.0 to $2.0 \mathrm{ft}$ ) [Unused for interior windows]

SHADING-SCHEDULE(S-SCH) u-name

MAX-SOLAR-SCH(M-S-SCH) u-name

SUN-CTRL-PROB(S-C-P)(1.0;0.0 to 1.0$)$

OPEN-SHADE-SCH(O-S-SCH) u-name [Unused for interior windows]

WIN-SHADE-TYPE(W-S-T)(MOVABLE-INTERIOR;MOVABLE-INTERIOR, MOVABLE-EXTERIOR,FLXED-INTERIOR,FIXED-EXTERIOR) $\dagger$

CONDUCT-SCHEDULE(C-SCH) u-name

CONDUCT-TMIN-SCH(C-T-SCH) u-name

OVERHANG-A(OH-A)(0.0;no limits - $\mathrm{ft}$ ) [Unused for interior windows]

OVERHANG-B(OH-B)(0.0;no limits - $\mathrm{ft}$ ) [Unused for interior windows]

OVERHANG-W $(\mathrm{OH}-\mathrm{W})(0.0 ; 0.0$ to no limits $-\mathrm{ft})$ [Unused for interior windows]**

and**

OVERHANG-D(OH-D)(0.0;0.0 to no limits - $\mathrm{ft}$ ) [Unused for interior windows] ${ }^{* *}$

OVERHANG-ANGLE(OH-ANG)(90.0;0.0 to $\left.180^{\circ}\right)$ [Unused for interior windows]

LEFT-FIN-A(L-F-A)(0.0;no limits - $\mathrm{ft}$ ) [Unused for interior windows]

LEFT-FIN-B(L-F-B)(0.0;no limits - $\mathrm{ft}$ ) [Unused for interior windows]

LEFT-FIN-H(L-F-H) $\left(0.0 ; 0.0\right.$ to no limits - $\mathrm{ft}$ ) [Unused for interior windows] ${ }^{* *}$

and**

LEFT-FIN-D(L-F-D)(0.0;0.0 to no limits - $\mathrm{ft}$ ) [Unused for interior windows] ${ }^{* *}$

RIGHT-FIN-A(R-F-A)(0.0;no limits - ft) [Unused for interior windows]

RIGHT-FIN-B(R-F-B)(0.0;no limits - $\mathrm{ft}$ ) [Unused for interior windows]

RIGHT-FIN-H(R-F-H)(0.0;0.0 to no limits - $\mathrm{ft})$ [Unused for interior windows]** and**

RIGHT-FIN-D(R-F-D)(0.0;0.0 to no limits $-\mathrm{ft})$ [Unused for interior windows]**

SKY-FORM-FACTOR(S-F-F)(-;0.0 to 1.0$)^{*}$

and*

GND-FORM-FACTOR(G-F-F)(-;0.0 to 1.0) [Unused for interior windows]*

SHADING-DIVISION(S-D)(10;1 to 40) (all integers) [Unused for interior windows]

INF-COEF(I-C)(0.0;0.0 to 160.0 units) [Unused for interior windows]

SOL-TRANS-SCH(S-T-SCH) u-name ***

VIS-TRANS-SCH(V-T-SCH) u-name [Unused for interior windows] $\dagger$

GLARE-CTRL-PROB(G-C-P)(1.0;0.0 to 1.0) [Unused for interior windows]

INSIDE-VIS-REFL(I-V-R)(0.15;0.0 to 1.0) [Unused for interior windows]

FUNCTION (*u-name*, ${ }^{*}$ u-name*) [Unused for interior windows]

WINDOW-SPEC-FN *u-name* [Unused for interior windows]

- Either both or neither of these should be specified. If not specifed, the program will calculate them.

* Either both or neither of these should be specifed. If not specifed, shading calculation will not be done.

*** Used only if an exterior window in a space with SUNSPACE $=$ YES.

$\dagger$ Required for daylighting calculation if SHADING-SCHEDULE is specified.

it Used only for exterior windows in spaces with DAYLIGHTING = YES or SUNSPACE $=$ YES;

unused if window has no SHADING-SCHEDULE.

$\ddagger$ Used only if DAYLIGHTING-METHOD = CRACK in SPACE or SPACE-CONDITIONS 
$\Rightarrow$ WINDOW(WI)(200) |Continued |

The following keywords are used only for switchable glazing in exterior windows:

- GLASS-TYPE-SW(G-T-SW) u-name

- SWITCH-CONTROL(SW-C) (NO-SWITCH;NO-SWITCH,DIR-SOL-INC, TOT-SOL-INC,DIR-SOL-TR,TOT-SOL-TR,TOT-SOL-HOR,OUTSDE-TEMP, SPACE-LOAD,DAYLIGHT-LEVEL)

- SWITCH-SET-HI(SW-SET-HI) $(-;-500.0$ to 500.0) [See table below for units] $\dagger$

- SWITCH-SET-LO(SW-SET-LO) $(-;-500.0$ to 500.0 ) [See table below for units] $\dagger$

- SWITCH-SCH(SW-SCH) u-name

+ Unused for SWITCH-CONTROL=DAYLIGHT-LEVEL

\begin{tabular}{|l|l|}
\hline SWITCH-CONTROL & $\begin{array}{l}\text { Units of SWITCH-SET-HI and -LO } \\
\text { (for English and metric runs) }\end{array}$ \\
\hline NO-SWITCH & no units used \\
DIR-SOL-INC & Btu/h-ft ${ }^{2}$ [glass] \\
TOT-SOL-INC & Btu/h-ft ${ }^{2}$ [glass] \\
DIR-SOL-TR & Btu/h-ft ${ }^{2}$ [glass] \\
TOT-SOL-TR & Btu/h-ft ${ }^{2}$ [glass] \\
TOT-SOL-HOR & Btu/h-ft ${ }^{2}$ \\
OUTSIDE-TEMP & ${ }^{\text {o F }}$ \\
SPACE-LOAD & Btu/h-ft ${ }^{2}$ [lloor] \\
DAYLIGHT-LEVEL & no units used \\
\hline
\end{tabular}


$\Leftrightarrow \operatorname{DOOR}(64)$

- HEIGHT(H) $(-; 0.0$ to $40.0 \mathrm{ft})$

- WDTH(W)( - $; 0.0$ to $1000.0 \mathrm{ft})$

- CONSTRUCTION(CONS) u-name of a quick-type (U-value) CONSTRUCTION

MULTIPLER(M)(1.0;0.0 to 99.0)

SETBACK(SETB)(0.0;0.0 to $10.0 \mathrm{ft})$

OVERHANG-A $(\mathrm{OH}-\mathrm{A})(0.0$;no limits - $\mathrm{ft})$

OVERHANG-B(OH-B)(0.0;no limits - $\mathrm{ft})$

OVERHANG-W(OH-W)(0.0;0.0 to no limits $-\mathrm{ft})^{* *}$

and**

OVERHANG-D(OH-D) $(0.0 ; 0.0$ to no limits - $\mathrm{ft}$ )**

OVERHANG-ANGLE(OH-ANG)(80.0;0.0 to $\left.180^{\circ}\right)$

LEFT-FIN-A(L-F-A)(0.0;no limits - $\mathrm{ft}$ ) .

LEFT-FIN-B(L-F-B)(0.0;no limits - ft)

LEFT-FIN-H(L-F-H) $(0.0 ; 0.0 \text { to no limits - } \mathrm{ft})^{* *}$

and**

LEFT-FIN-D(L-F-D)(0.0;0.0 to no limits - $\mathrm{ft}$ )**

RIGHT-FIN-A(R-F-A)(0.0;no limits - $\mathrm{ft})$

RIGHT-FIN-B(R-F-B)(0.0;no limits - $f t)$

RIGHT-FIN-H(R-F-H) $(0.0 ; 0.0 \text { to no limits - ft })^{* *}$

and**

RIGHT-FIN-D(R-F-D)(0.0;0.0 to no limits - $\mathrm{ft})^{* *}$

$\mathrm{X}(0.0$;no limits - $\mathrm{ft})$

$\mathrm{Y}(0.0$;no limits - $\mathrm{ft})$

SKY-FORM-FACTOR(S-F-F)(一;0.0 to 1.0)*

and*

GND-FORM-FACTOR(G-F-F)(-;0.0 to 1.0$)^{*}$

SHADING-DIVISION(S-D) $(10 ; 1$ to 40$)$ (all integers)

INF-COEF(I-C)(0.0;0.0 to 500.0 units) [See table below for typical values.]

INSIDE-VIS-REFL(I-V-R)(0.5;0.0 to 1.0$)$ [Used only for daylighting calculation.] FUNCTION ( ${ }^{*}$ u-name ${ }^{*}{ }^{*}$ u-name ${ }^{*}$ )

* Either both or neither of these should be specified. If not specifed, the program will calculate them.

** Either both or neither of these should be specifed. If not specified, shading calculation will not be done.

\begin{tabular}{|c|c|}
\hline \multicolumn{2}{|l|}{ Door Infiltration Coefficients } \\
\hline Door Configuration & INF-COEF \\
\hline $\begin{array}{l}\text { 1. Door-Residential } 3 \text {-ft } \times 7 \text {-ft: } \\
\text { closed with weather stripping } \\
\text { average use with weather stripping. } \\
\text { average use without weather stripping }\end{array}$ & $\begin{array}{r}2.4 \\
9.8 \\
12.0\end{array}$ \\
\hline $\begin{array}{l}\text { 2. Door-Office } 3.5 \mathrm{ft} \times 7-\mathrm{ft} \text { : } \\
\text { door closed } \\
\text { door and vestibule open } 10 \% \text { of time } \\
\text { door open } 10 \% \text { of time } \\
\text { door open } 25 \% \text { of time } \\
\text { door open } 50 \% \text { of time }\end{array}$ & $\begin{array}{r}3.1 \\
9.3 \\
13.5 \\
55.0 \\
153.0\end{array}$ \\
\hline 3. Door-Revolving, average use & 12.0 \\
\hline $\begin{array}{l}\text { 4. Garage or Shipping Room Door: } \\
\text { no use } \\
\text { average use }\end{array}$ & $\begin{array}{r}6.0 \\
60.0\end{array}$ \\
\hline
\end{tabular}




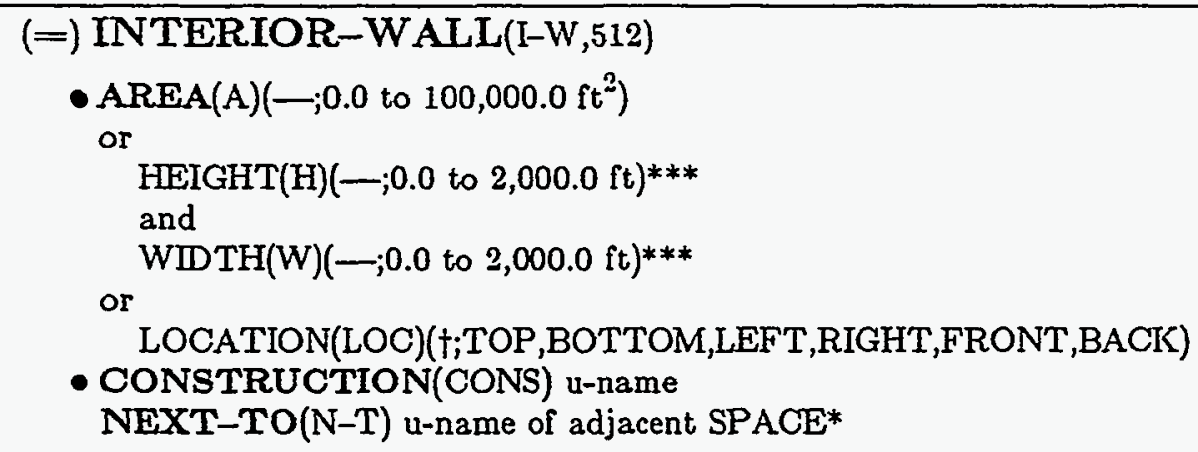

INT-WALL-TYPE(I-W-TYPE)(STANDARD;STANDARD,AIR,ADIABATIC,INTERNAL) TLT $\left(80.0 ; 0.0\right.$ to $\left.180.0^{\circ}\right) \ddagger$

SOLAR-FRACTION(S-F)( $+\dagger$ );0.0 to 1.0) (list of two) [used only when CWF are to be calculated] tt INSDE-VIS-REFL(I-V-R) $(* ; 0.0$ to 1.0 ) (list of two) [ Used only for daylighting calculation.] t+t $\mathrm{X}(0.0 \text {; no limits }-\mathrm{ft})^{* * *}$

$\mathrm{Y}(0.0 \text {; no limits }-\mathrm{ft})^{* * *}$

$\mathrm{Z}(0.0$; no limits - $\mathrm{ft}) * * * *$

AZIMUTH(AZ) $\left(0.0 ;-360.0 \text { to } 360.0^{\circ}\right)^{* * *}$

INSIDE-SOL-ABS(I-S-A)( $\ddagger ; ; 0.0$ to 1.0 ) (list of 2$)+t \dagger$

* Required if INT-WALL-TYPE = STANDARD or AIR; otherwise, unused.

** Default is 0.2 if loor (TLT $>170^{\circ}, 0.5$ if wall $\left(10 \leq \mathrm{THT} \leq 170^{\circ}\right.$, and 0.7 if ceiling (TLT $<10^{\circ}$ ).

*** Used only if either side of wall is in a space with SUNSPACE $=$ YES.

$\dagger$ Required if SHAPE keyword is used in SPACE command.

H If not speciffed, program will distribute according to total surface area, with the floor receiving the greater weight.

HI First value in the list of two is for the side of the wall that is in the space the wall is defined in; second value is for the side of the wall that is in the NEXT-TO space.

¥ Used only if (a) CWF are being calculated;

(b) either side of wall is in a space with DAYLIGHTING = YES; or

(c) either side of wall is in a space with SUNSPACE $=$ YES.

\# Default is $(0.8,0.3)$ if foor (TLT $\left.>170^{\circ}\right),(0.5,0.5)$ if wall $\left(10^{\circ} \leq \mathrm{TLT} \leq 170^{\circ}\right.$ ), and $(0.3,0.8)$ if ceiling (TIT $<10^{\circ}$ ). 
$\Leftrightarrow$ UNDERGROUND-WALL(U-W) or UNDERGROUND-FLOOR(U-F)(64)

- AREA(A)(-;0.0 to $\left.100,000.0 \mathrm{ft}^{2}\right)$

or

HEIGHT(H)(-;0.0 to $2,000.0 \mathrm{ft})$

and

$\mathrm{WDTH}(\mathrm{W})(-; 0.0$ to $2,000.0 \mathrm{ft})$

or

LOCATION(LOC)(†;TOP,BOTTOM,LEFT,RIGHT,FRONT,BACK)

- CONSTRUCTION(CONS) u-name

TIIT $\left(80.0 ; 0.0\right.$ to $\left.180.0^{\circ}\right) \ddagger$

* U-EFFECTIVE(U-EFF)(-;0.0 to $20.0 \mathrm{Btu} / \mathrm{hr}-\mathrm{ft}^{2}-\mathrm{O}$ F) $+\mathrm{t \dagger}$

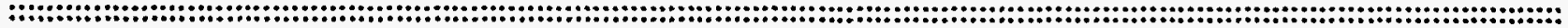

MULTIPLER(M)(1.0;0.0 to 99.0$)$

SOLAR-FRACTION(S-F)(t+;0.0 to 1.0) [Used only if CWF are to be calculated.]

INSDE-VIS-REFL(I-V-R) $(* * ; 0.0$ to 1.0$)$ [Used only for daylighting calculation.]

INSDE-SOL-ABS(I-S-A)(***;0.0 to 1.0$)$

FUNCTION (*u-name*, ${ }^{*} \mathrm{u}$-name $\left.{ }^{*}\right)$

- If a delayed CONSTRUCTION was input for CWF calculation, U-EFFECTIVE is the appropriate U-value to be used for the hourly simulation.

** Default is 0.2 if loor (TILT $>170^{\circ}$ ), 0.5 if wall $\left(10 \leq\right.$ TLT $\leq 170^{\circ}$ ), and 0.7 if ceiling (TILT $<10^{\circ}$ ).

*** Default is 0.8 if floor (TLT $>170^{\circ}$ ), 0.5 if wall $\left(10^{\circ} \leq \mathrm{TLT} \leq 170^{\circ}\right)$, and 0.3 if ceiling (TIL $<<10^{\circ}$ ).

$\dagger$ Required if SHAPE keyword is used in SPACE command.

If If not specified, program will distribute according

to total surface area, with the floor receiving

the greater weight.

tit Used only for automatic calculation of Custom Weighting Factors.

\# Tilt for UNDERGROUND-FLOOR must be input, otherwise it will default to $180^{\circ}$

A set-default for UNDERGROUND-WALL will also reset the default for UNDERGROUND-FLOOR.

\section{BUILDING-RESOURCE(B-R,1)}

See the PLANT-ASSIGNMENT command in SYSTEMS, p.42.

LOADS-REPORT(L-R,1)

VERIFICATION(V)(一;LV-A,LV-B,...,LV-M,ALL-VERIFICATION)(list)

SUMMARY(S)(LS-D;LS-A,LS-B,...,LS-L,ALL_SUMMARY)(list)

REPORT-FREQUENCY(R-F)(HOURLY;HOURLY,DAILY,MONTHLY,YEARLY)

HOURLY-DATA-SAVE(H-D-S)(NO;BINARY,FORMATTED) 1 changed in 2.1E

[See page 100 for brief description; Chapter III of the Reference Manual (2.1A) for definitions; and

Appendix $\mathrm{C}$ of the Supplement (2.1E) for a full description of all repc:ts.]

$=$ REPORT-BLOCK(R-B,64)

- VARIABLE-TYPE(V-T) (-;GLOBAL,END-USE,BULDING,u-name of SPACE, u-name of ROOF or EXTERIOR-WALL, u-name of WINDOW, u-name of DOOR)

- VARLABLE-LIST(V-L)(一;code-numbers†) (list)

$\dagger \quad$ For code-number lists, see Appendix A of the Supplement (2.1E) 
$=$ HOURLY-REPORT(H-R,16)

- REPORT-SCHEDULE(R-SCH) u-name

- REPORT-BLOCK(R-B) (list of u-names of Report Blocks)(30 max.)

OPTION(O)(PRINT;PRINT,PLOT,BINARY-FLE)

DIVIDE(1.0;no limits) $\dagger$

AXIS-ASSIGN $(A-A)(1 ; 1,2)$ (in tegers) $\dagger$

AXIS-MAX(A-MAX) (一; no limits) $\ddagger$

AXIS-MIN(A-MIN) $(-;$ no limits $) \ddagger$

AXIS-TITLES(A-T) (*"Axis 1 Title"*,*"Axis 2 Title"*)[Each title must be 16 characters or less.]

Note: Total number of VARLABLE-LIST variables in all Report Blocks may not exceed 60 in any HOURLY-REPORT

+ List DIVIDE and AXIS-ASSIGN for all variables listed in R-B in the corresponding order; max 12 variables in PLOT option.

$\ddagger$ If PLOT option chosen, then A-MAX and A-MIN are required for each axis.

\section{END}

Required at end of LOADS input

and before FUNCTION command, if specified.

FUNCTION(100)

- NAME u-name of function

- LEVEL(一;BUILDING(or BLDG),SPACE,EXTERIOR-WALL(or E-W), UNDERGROUND-WALL(or U-W), WINDOW, DOOR)

Note: Up to 100 block sequences of FUNCTION, ASSIGN, CALCULATE, and END-FUNCTION may be defined.

\section{ASSIGN (100)}

- Local variable name $=$ DOE-2 simulation variable name

or a single numeric value

or a PARAMETER name set equal to a numeric or constant

or to a SCHEDULE-NAME (u-name of a schedule)

or schedule(global variable name of schedule).

- Table variable name $=$ table (lists of data points)

\section{CALCULATE $(100)$}

Required to do FUNCTION calculation

Note: Follow this command (after the terminator) with the FORTRAN-like statements which define the desired function. As in standard FORTRAN, statement numbers must appear in columns 1-5, column 6 is used to designate a statement continuation, and statements must begin in or after column 7 , and end before 72. The last statement must be END.]

See p.1.11 of the Supplement (2.1E) for a list of valid FORTRAN declarative and executable statements.]

\section{END-FUNCTION(100)}

Required at end of FUNCTION input 
LOADS

\section{COMPUTE LOADS}

(Maximum of 100 total COMPUTE LOADS, SYSTEMS, PLANT, ECONOMICS commands)

Required to do Loads simulation

\section{SAVE-FILES}

Use only if saving LOADS output for subsequent runs

STOP

Use only if want BDL and simulation to stop here 


\section{SYSTEMS SUMMARY}

INPUT SYSTEMS Required for Systems input

Note: Maximum total INPUT plus PARAMETRIC-INPUT commands is 100

INPUT-UNITS(ENGLISH;ENGLISH,METRIC)

OUTPUT-UNITS(ENGLISH;ENGLISH,METRIC)

\section{PARAMETRIC-INPUT SYSTEMS}

Note: Maximum total INPUT plus PARAMETRIC-INPUT commands is 100

INPUT-UNITS(ENGLISH;ENGLISH,METRIC)

OUTPUT-UNITS(ENGLISH;ENGLISH,METRIC)

Note: Replaces INPUT SYSTEMS for parametric runs

\section{TITLE(5)}

See LOADS

\section{ABORT}

(only needed when overriding value input in LOADS)

\section{DLAGNOSTIC(LIST)}

(only needed when overriding value input in LOADS)

\section{PARAMETER(DEFINE)}

See LOADS

$=$ CURVE-FIT(C-F,100)

- TYPE(一;LINEAR,BI-LINEAR,QUADRATIC,BI-QUADRATIC,CUBIC)

OUTPUT-MIN(-;-1,000,000.0 to $10,000,000.0)$

OUTPUT-MAX(-; $-1,000,000.0$ to $10,000,000.0)$

- DATA (up to 20 lists of data points)

or

- COEFFICIENTS(COEF) (list of up to 6 coefficients)

$=\mathrm{DAY}-\mathrm{SCHEDULE}(\mathrm{D}-\mathrm{SCH}, 300)$

See LOADS

= WEEK-SCHEDULE(W-SCH,200)

See LOADS 
$=$ SCHEDULE(SCH,100) Note:LIKE keyword not allowed See LOADS

$=$ DAY-RESET-SCH(D-R-SCH, 300 minus the number of D-SCH's)

- SUPPLY-HI(S-H) (-;0.0 to $\left.120.0^{\circ} \mathrm{F}\right)$ or $(-; 0.0$ to 1.0$)$

- SUPPLY-LO(S-L) $\left(-; 0.0\right.$ to $\left.120.0^{\circ} \mathrm{F}\right)$ or $(-; 0.0$ to 1.0$)$

- OUTSIDE-HI $(\mathrm{O}-\mathrm{H})\left(-;-20.0\right.$ to $\left.120.0^{\circ} \mathrm{F}\right)$

- OUTSIDE-LO(O-L)(-; -20.0 to $\left.120.0^{\circ} \mathrm{F}\right)$

= RESET-SCHEDULE(R-SCH,100 minus the number of SCH's)

See LOADS Note:LIKE keyword not allowed

$=\mathrm{ZONE}-\mathrm{CONTROL}(\mathrm{Z}-\mathrm{C}, 50)$

DESIGN-HEAT-T(D-H-T $)\left(70^{\circ} \mathrm{F} ; 0.0\right.$ to $\left.80^{\circ} \mathrm{F}\right)$

HEAT-TEMP-SCH(H-T-SCH) u-name [If omitted, no heating or cooling, respectively, in zone.]

DESIGN-COOL-T(D-C-T $)\left(76^{\circ} \mathrm{F} ; 0.0\right.$ to $\left.90^{\circ} \mathrm{F}\right)$

COOL-TEMP-SCH(C-T-SCH) u-name [I omitted, no heating or cooling, respectively, in zone.]

BASEBOARD-CTRL(B-C)(OUTDOOR-RESET;OUTDOOR-RESET, THERMOSTATIC)

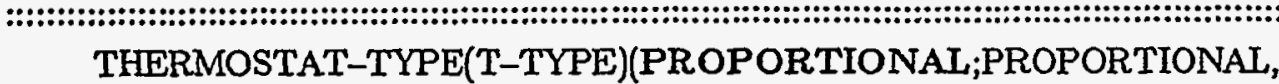

REVERSE-ACTION,TWO-POSITION)

THROTTLING-RANGE(T-R) $\left(\dagger ; 0.1\right.$ to $\left.10.0^{\circ} \mathrm{F}\right)$

$\dagger$ Default is 2.0 if THERMOSTAT-TYPE $=$ PROPORTIONAL or REVERSE-ACTION, 0.5 if TWO-POSITION. 
$=\mathrm{ZONE}-\mathrm{AIR}(\mathrm{Z}-\mathrm{A}, 50)$

ASSIGNED-CFM(A-CFM)(-;0.0 to $99999999.0 \mathrm{cfm})$

or

CFM/SQFT(-;0.0 to $\left.5.0 \mathrm{cfm} / \mathrm{ft}^{2}\right)$

or

AIR-CHANGES/HR(A-C/HR)(-;0.0 to $10.0 / \mathrm{hr})$

OUTSIE-AIR-CFM(O-A-CFM)(—;0.0 to $99999999.0 \mathrm{cfm})$

or

OA-CFM/PER(O-CFM/P)(-;0.0 to $60.0 \mathrm{cfm} /$ person $)$

or

OA-CHANGES(O-C)(-;0.0 to $10.0 / \mathrm{hr})$

EXHAUST-CFM(E-CFM)( $\dagger ; 0.0$ to $99999999.0 \mathrm{cfm})$

EXHAUST-STATIC(E-S) $(+; 0.0$ to 10.0 in of WG)

EXHAUST-EFF(E-E)(0.75;0.1 to 1.0$)$

EXHAUST-KW(E-KW) $(\dagger ; 0.0$ to 0.01$)$

SS-VENT-SCH(S-V-SCH) u-name [Used only for zones with SUNSPACE = YES.]

SS-VENT-T-SCH(S-V-T-SCH) u-name [Used only for zones with SUNSPACE = YES.]

SS-VENT-CST(S-V-CST) $(5.0 ; 0.0$ to $20.0 \mathrm{ach}$ ) [Used only for zones with SUNSPACE $=$ YES.]

SS-VENT-WND(S-V-WND)(0.0;0.0 to $5.0 \mathrm{ach} / \mathrm{knot})$ [Used only for zones with SUNSPACE $=$ YES.]

SS-VENT-TEMP(S-V-TEMP) $\left(0.0 ; 0.0\right.$ to $\left.1.0 \mathrm{ach} /{ }^{\circ} \mathrm{F}\right)$ [Used only for zones with SUNSPACE = YES.]

SS-VENT-LIMIT-T(S-V-L-T) $\left(120.0 ; 0.0\right.$ to $140.0^{\circ} \mathrm{F}$ ) [Used only for zones with SUNSPACE = YES.]

SS-VENT-KW(S-V-KW $)(0.0 ; 0.0$ to $0.01 \mathrm{~kW} / \mathrm{cfm})$ [Used only for zones with SUNSPACE = YES.]

SS-FLOW-SCH(SS-F-SCH) u-name [Used only for zones with SUNSPACE = YES.]

SS-FLOW-T-SCH *u-name* (Defaults to $74^{\circ} \mathrm{F}$ )

$t$ System-dependent; see page 62, Index of System Types, for default values

$=\mathrm{ZONE}-\mathrm{FANS}(\mathrm{Z}-\mathrm{F}, 50)$ [Used only for PIU system.]

- ZONE-FAN-RATIO(Z-F-R) $(\dagger ; 0.0$ to 10.0)

or

- ZONE-FAN-CFM(Z-F-CFM $)\left(\dagger ; 0.0\right.$ to $\left.99999999.0 \mathrm{ft}^{3} / \mathrm{min}\right)$

- ZONE-FAN-T-SCH(Z-F-SCH) u-name [Required if TERMINAL-TYPE = PARALLEL-PIU.]

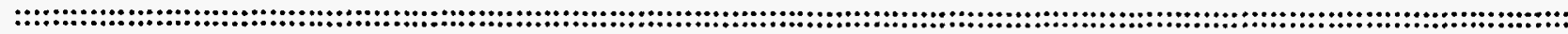

ZONE-FAN-KW(Z-F-IKW)(0.00033;0.0 to $0.01 \mathrm{~kW} / \mathrm{cfm})$

$\dagger$ For series PIU, ZONE-FAN-RATIO defaults to 1.0. However, defaulting is not allowed for parallel PIU; therefore, user must input -RATIO or -CFM.

$\bullet=$ Required keyword 
$=\mathrm{ZONE}(\mathrm{Z}, 128)$ [Continued on next page

ZONE-TYPE(Z-TYPE)(CONDITIONED;CONDITIONED,UNCONDITIONED,PLENUM)

ZONE-CONTROL(Z-C) u-name §

ZONE-AIR(Z-A) u-name §

ZONE-FANS(Z-F) u-name $\S$

ZONE-REPORTS(YES;YES or NO for SUMMARY reports for this ZONE)

MIN-CFM-RATIO(M-C-R) $(\dagger ; 0.0$ to 1.0$)$

COOLING-CAPACTTY(C-CAP) $(\dagger ; 0.0$ to $99999999.0 \mathrm{Btu} / \mathrm{hr})$

COOL-SH-CAP $(\mathrm{C}-\mathrm{S}-\mathrm{C})(\dagger ; 0.0$ to $99999999.0 \mathrm{Btu} / \mathrm{hr})$

HEATING-CAPACITY(H-CAP)(t;-999999999.0 to $0.0 \mathrm{Btu} / \mathrm{hr})$

MIN-CFM-SCH(M-C-SCH) u-name

SIZING-OPTION(S-0)(FROM-LOADS;FROM-LOADS,ADJUST-LOADS)

TERMINAL-TYPE(TER-TYPE)(SVAV;SVAV,SERIES-PIU,PARALLEL-PIU) $\dagger$

INDUCED-AIR-ZONE(I-A-Z) u-name of ZONE ††

REHEAT-DELTA-T(R-D-T) (-;0.0 to $\left.100.0^{\circ} \mathrm{F}\right)$ t†

BASEBOARD-RATING(B-R)(0.0;-99999999.0 to $0.0 \mathrm{Btu} / \mathrm{hr})$

PÁNEL-LOSS-RATIO(P-L-R)(0.0;0.0 to 2.0)

MULTIPLIER(M)( $\dagger ; ; 1.0$ to 50.0) [Defaults to value in corresponding SPACE in LOADS]

FLOOR-MULTIPLIER(F-M)(††;1.0 to 200.0) [Defaults to value in corresponding SPACE in LOADS]

MAX-HEAT-RATE(MAX-H-R)(†;-99999999.0 to $0.0 \mathrm{Btu} / \mathrm{hr})$

MAX-COOL-RATE(MAX-C-R)(†;0.0 to $999999999.0 \mathrm{Btu} / \mathrm{hr})$

TROM-VENT-SCH(T-V-SCH) u-name [Used only for vented Trombe walls]

FUNCTION(*u-name*, $u$-name*)

Note: the following REFG-type keywords used only for PSZ refrigeration simulation.

REFG-ZONE-LOAD(*;-99999999.0 to $0.0 \mathrm{Btu} / \mathrm{hr}$ ) (list of up to three)

REFG-ZONE-SHR(0.8,0.8,0.8;0.0 to 1.0 ) (list of up to three)

REFG-ZONE-DES-T(75.0,75.0,75.0;30.0 to $100.0^{\circ} \mathrm{F}$ ) (list of up to three)***

REFG-ZONE-DES-RH(55.0,55.0,55.0;20.0 to 100.0\%) (list of up to three)

REFG-DISCHARGE-T $\left(* ;-40.0\right.$ to $60.0^{\circ} \mathrm{F}$ ) (list of up to three)

REFG-EVAP-T $\left(* * ;-40.0\right.$ to $\left.60.0^{\circ} \mathrm{F}\right)$ (list of up to three)

REFG-SENS-SCH (list of up to three u-names)

REFG-LAT-SCH (list of up to three u-names)

REFG-AUX-KW (ttt; 0.0 to $100.0 \mathrm{~kW}$ ) (list of up to three)

REFG-AUX-HEAT $(0.0,0.0,0.0 ; 0.0$ to $99999999.0 \mathrm{Btu} / \mathrm{hr}$ ) (list of up to three)

REFG-AUX-SCH (list of up to three u-names)

- Required for simulation of refrigeration

** Defaults to corresponding (REFG-DISCHARGE-T) $-10^{\circ} \mathrm{F}$

*** Values must be greater than corresponding REFG-EVAP-T values

$\dagger \quad$ System-dependent; see page 62, Index of System Types, for default values

H Used only for PIU system; I-A-Z required if TERMINAL-TYPE $\neq$ SVAV

Itt Deraults to $(0.4)$ * (the corresponding REFG-2ONE-LOAD value/12,000)

$\ddagger$ Deraults to $0.9,0.8,0.9$, unless corresponding REFG-DEF-MECH=TIME-OFF

in which case defaults to $1.0,1.0,1.0$.

§ Any keyword from these subcommands may be placed in the ZONE command 
$=\mathrm{ZONE}(\mathrm{Z}, 128) \mid$ Continued $\mid$

REFG-DEF-MECH (RESISTANCE,RESISTANCE,RESISTANCE;

RESISTANCE,FREON,TIME-OFF,NO-DEFROST) (list of up to three)

REFG-DEF-EFF ( $¥ ; 0.1$ to 1.0$)$ (list of up to three)

REFG-DEF-CTRL (THERMOSTATIC,THERMOSTATIC,THERMOSTATIC;

THERMOSTATIC,TIMER) (list of up to three)

All the metering keywords listed under the PLANT-ASSIGNMENT command on p.43 may be entered at the ZONE level. The following metering keywords allow you to assign electric and fuel meters to specific end uses.

- MSTR-ELEC-METER(MSTR-EM) (M1;M1,M2,M3,M4,M5)

- MSTR-FUEL-METER(MSTR-FM) (M1;M1,M2,M3,M4,M5)

- LIGHT-ELEC-METER(LIGHT-EM) (MSTR-ELEC-METER;M1,M2,M3,M4,M5)

- TASK-ELEC-METER(TASK-EM) (MSTR-ELEC-METER;M1,M2,M3,M4,M5)

- EQUIP-ELEC-METER(EQUIP-EM) (MSTR-ELEC-METER;M1,M2,M3,M4,M5)

- SOURCE-ELEC-METER(SRC-EM) (MSTR-ELEC-METER;M1,M2,M3,M4,M5)

- HEAT-ELEC-METER(HEAT-EM) (MSTR-ELEC-METER;M1,M2,M3,M4,M5)

- COOL-ELEC-METER(COOL-EM) (MSTR-ELEC-METER;M1,M2,M3,M4,M5)

- HTREJ-ELEC-METER(HTREJ-EM) (MSTR-ELEC-METER;M1,M2,M3,M4,M5)

- AUX-ELEC-METER(AUX-EM) (MSTR-ELEC-METER;M1,M2,M3,M4,M5)

- VENT-ELEC-METER(VENT-EM) (MSTR-ELEC-METER;M1,M2,M3,M4,M5)

- REFG-ELEC-METER(REFG-EM) (MSTR-ELEC-METER;M1,M2,M3,M4,M5)

- SUPP-ELEC-METER(SUPP-EM) (MSTR-ELEC-METER;M1,M2,M3,M4,M5)

- DHW-ELEC-METER(DHW-EM) (MSTR-ELEC-METER;M1,M2,M3,M4,M5)

- SOURCE-FUEL-METER(SRC-FM) (M1;M1,M2,M3,M4,M5)

- HEAT-FUEL-METER(HEAT-FM) (MSTR-FUEL-METER;M1,M2,M3,M4,M5)

- COOL-FUEL-METER(COOL-FM) (MSTR-FUEL-METER;M1,M2,M3,M4,M5)

- SUPP-FUEL-METER(SUPP-FM) (MSTR-FUEL-METER;M1,M2,M3,M4,M5)

- DHW-FUEL-METER(DHW-FM) (MSTR-FUEL-METER;M1,M2,M3,M4,M5)

* Required for simulation of refrigeration

** Defaults to corresponding (REFG-DISCHARGE-T) $-10^{\circ} \mathrm{F}$

*** Values must be greater than corresponding REFG-EVAP-T values

$\dagger \quad$ System-dependent; see page 62, Index of System Types, for default values

It Used only for PIU system; I-A-Z required if TERMINAL-TYPE $\neq$ SVAV

$\mathrm{HI}$ Defaults to $(0.4)$ (the corresponding REFG-ZONE-LOAD value/12,000)

$\ddagger \quad$ Defaults to $0.9,0.9,0.8$, unless corresponding REFG-DEF-MECH=TIME-OFF

in which case defaults to 1.0,1.0,1.0.

\$ Any keyword from these subcommands may be placed in the ZONE command 
= SYSTEM-CONTROL $(\mathrm{S}-\mathrm{C}, 50)$

MAX-SUPPLY-T(MAX-S-T) $\left(\dagger ; 50.0\right.$ to $\left.200.0^{\circ} \mathrm{F}\right)$

MIN-SUPPLY-T(MIN-S-T) $\left(\dagger ; 35.0\right.$ to $\left.70.0^{\circ} \mathrm{F}\right)$ a changed in $2.1 \mathrm{E}$

COOL-CONTROL(C-C)(CONSTANT;CONSTANT,WARMEST,RESET,SCHEDULED)

ECONO-LIMIT-T(E-L-T) $\left(\dagger ; 45.0\right.$ to $\left.80.0^{\circ} \mathrm{F}\right)$

- DRYBULB-LIMIT(none; 45.0 to $80.0^{\circ} \mathrm{F}$ )

- ENTHALPY-LIMIT(none;0.0 to 100Btu/lb-dry air)

:::::::::::::::::::::::::::::::::::::::::::::::::::::::::::::::::

HEATING-SCHEDULE(H-SCH) u-name

COOLING-SCHEDULE(C-SCH) u-name

HEAT-CONTROL(H-C)(CONSTANT;CONSTANT,COLDEST,RESET,SCHEDULED)

HEAT-SET-T(H-S-T) $\left(\dagger ; 50.0\right.$ to $\left.200.0^{\circ} \mathrm{F}\right)$.

HEAT-RESET-SCH(H-R-SCH) u-name of RESET-SCHEDULE

HEAT-SET-SCH(H-S-SCH) u-name

COOL-SET-T $(C-S-T)\left(t ; 35.0\right.$ to $\left.70.0^{\circ} \mathrm{F}\right)$ a changed in $2.1 \mathrm{E}$

COOL-RESET-SCH(C-R-SCH) u-name of RESET-SCHEDULE

COOL-SET-SCH(C-S-SCH) u-name

- MIN-SUPPLY-SCH(M-S-SCH) u-name

MAX-HUMIDITY(MAX-H)(100.0;30.0 to 80.0\%)

MIN-HUMDITY(MIN-H)(0.0;0.0 to 70.0\%)

- ECONO-LOCKOUT(-;YES for PSZ, NO for PVAVS, PMZS, and PVVT)

ECONO-LOW-LIMTT(E-L-L) $\left(0.0 ; 0.0\right.$ to $\left.80.0^{\circ} \mathrm{F}\right)$

PREHEAT-T(P-T $)\left(45.0 ;-50.0\right.$ to $\left.70.0^{\circ} \mathrm{F}\right)$

- WS-ECONO(NO;NO,YES for System Type PSZ, PVAVS, and PVVT)

- WS-ECONO-MIN-DT(5.0;0.0 to 10.0F for System Type PSZ, PVAVS, and PVVT)

$t$ System-dependent; see page 62, Index of System Types, for default values

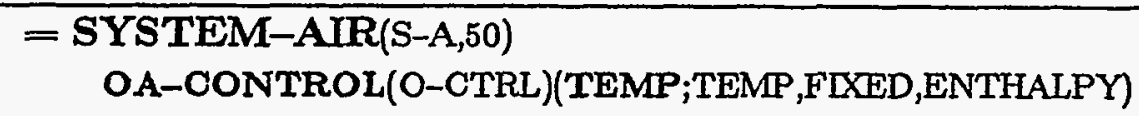

SUPPLY-CFM(S-CFM) $(\dagger+; 10.0$ to $9999999.0 \mathrm{cfm})$ [ + Calculated from ZONE-AR input and zone loads.] RETURN-CFM(R-CFM)( $+\dagger ; 10.0$ to $9999999.0 \mathrm{cfm}$ ) [ + Calculated from ZONE-AIR input and zone loads.] see page 62, Index of System Types, for default values.]

MIN-OUTSIDE-AIR(M-O-A)( $\dagger+; 0.0$ to 1.0$)$ [ $t$ Calculated from ZONE-AIR input and zone loads.]

MAX-OA-FRACTION(M-O-F)(1.0;0.0 to 1.0$)$.

MIN-AIR-SCH(M-A-SCH) u-name

RECOVERY-EFF(REC-E)(0.0;0.2 to $0.8 \mathrm{Btu} / \mathrm{Btu})$

DUCT-AIR-LOSS(D-A-L) $(0.0 ; 0.0$ to 1.0$)$

DUCT-DELTA-T(D-D-T)(0.0;0.0 to $\left.10.0^{\circ} \mathrm{F}\right)$

VENT-METHOD(V-M)(AIR-CHANGE,AIR-CHANGE,S-G)

MAX-VENT-RATE(M-V-R $)(20 ; 0.0$ to 100.0$) \ddagger$

HOR-VENT-FRAC(H-V-F $)(0 ; 0.0$ to 1.0$) \ddagger$

FRAC-VENT-AREA(F-V-A)(0.5;0.0 to 1.0$) \ddagger$

OPEN-VENT-SCH(O-V-S) u-nameł

NATURAL-VENT-AC(N-V-A)(-;0.0 to 100.0 air changes/hr) $\ddagger$

NATURAL-VENT-SCH(N-V-SCH) u-nameł

VENT-TEMP-SCH(V-T-SCH) u-nameł

$\ddagger$ Used only for SYSTEM-TYPE $=$ RESYS.

- = Required keyword 
= SYSTEM-FANS(S-FANS,50)

FAN-SCHEDULE(F-SCH) U-name

FAN-CONTROL(F-C)(†;CONSTANT-VOLUME,SPEED,INLET,DISCHARGE,CYCLING, TWO-SPEED,FAN-EIR-FPLR)

SUPPLY-STATIC(S-S)( $\dagger ; 0.0$ to 15.0 in of $W G)$

and

SUPPLY-EFF(S-E) $(\dagger ; 0.1$ to 1.0$)$

or

SUPPLY-DELTA-T(SUP-D-T)( $† ; 0.0$ to $\left.30.0^{\circ} \mathrm{F}\right)$

and

SUPPLY-KW(S-KW)( $\dagger ; 0.0$ to $0.0 \mathrm{~kW} / \mathrm{crm})$

SUPPLY-MECH-EFF(S-M-E)( $+; 0.1$ to 1.0$)$

MOTOR-PLACEMENT(M-P)(IN-AIRFLOW;IN-AIRFLOW,OUTSIDE-AIRFLOW)

FAN-PLACEMENT(F-P)(DRAW-THROUGH;DRAW-THROUGH, BLOW-THROUGH)

RETURN-STATIC(R-S)( $+; 0.0$ to 10.0 in of WG)

and

RETURN-EFF(R-E)(†;0.1 to 1.0$)$

or

RETURN-DELTA-T(RET-D-T) $\left(\dagger ; 0.0\right.$ to $\left.30.0^{\circ} \mathrm{F}\right)$

and

RETURN-KW(R-IKW) $(\dagger ; 0.0$ to $0.01 \mathrm{~kW} / \mathrm{cfm})$

NIGHT-CYCLE-CTRL(N-C-C)(†;STAY-OFF,CYCLE-ON-ANY, CYCLE-ON-FIRST, ZONE-FANS-ONLY*) [*Used only for PIU systems]

\section{NIGHT-VENT-CTRL(N-V-C)(NOT-AVAILABLE;NOT-AVAILABLE,NIGHT-FAN,} NIGHT-FAN+REVERT,WHEN-SCHEDULED,SCHEDULED+DEMAND)

NIGHT-VENT-SCH(NT-V-SCH) u-namet†

NIGHT-VENT-DT(N-V-D)(5.0;0.0 to $\left.30.0^{\circ} \mathrm{F}\right)$

NIGHT-VENT-RATIOS(N-V-R)( $\ddagger ; 0.0$ to 5.0 ) (list of 6 )

MAX-FAN-RATIO(MAX-F-R)(1.1;1.0 to 1.5)

MIN-FAN-RATIO(MIN-F-R)(0.3;0.1 to 1.0$)$

LOW-SPEED-RATIOS(L-S-R)( $¥ ; 0.0$ to 1.0$)$ (list of 4 ) [ $\ddagger$ Defaults are $(1.0,1.0,1.0,1.0)$ ).]

FAN-EIR-FPLR(F-E-FPLR) u-name of linear, quadratic or cubic

- INDOOR-FAN-MODE(I-F-M)(CONTINUOUS;CONTINUOUS,INTERMTTENT)

- OUTSDE-FAN-CFLT u-name of quadratic curve

- OUTSDE-FAN-HFLT u-name of quadratic curve

(PSZ, PVAVS, and PVVT only)

† System-dependent; see page 62, Index of System Types, for default values

it Required if NIGHT-VENT-CTRL = WHEN-SCHEDULED or SCHEDULED+DEMAND.

$\#$ Required ir NIGHT-VENT-CTRL $\neq$ NOT-AVAILABLE. 
= SYSTEM-TERMINAL $(\mathrm{S}-\mathrm{T}, 50)$

REHEAT-DELTA-T(R-D-T) $\left(\dagger ; 0.0\right.$ to $\left.100.0^{\circ} \mathrm{F}\right)$

MIN-CFM-RATIO(M-C-R $)(\dagger ; 0.0$ to 1.0$)$

::::::::::::::::::::::::::m-RATIO(I-R)(-;1.0 to 10.0) 1 [ Required only for TPIU and FPIU systems

$\dagger$ System-dependent; see page 62, Index of System Types, for default values

= SYSTEM-FLUID(S-FLU,50)

MIN-FLUID-T(MIN-F-T)(from PLANT-ASSIGNMENT;32.0 to $80.0^{\circ} \mathrm{F}$ )

[Only applies to HP systems.) $\mathbf{v}$ changed in $2.1 \mathrm{E}$

MAX-FLUID-T(MAX-F-T)(from PLANT-ASSIGNMENT;50.0 to $100.0^{\circ} \mathrm{F}$ )

[Applies to HP, PSZ and PVAVS systems.] a changed in 2.1E

FLUID-HEAT-CAP(F-H-C)(一; 1.0 to $\left.999999999.0 \mathrm{Btu} / \mathrm{hr}-{ }^{\circ} \mathrm{F}\right)=$ [Removed in 2.1E.]

- FLUID-VOLUME(from PLANT-ASSIGNMENT;1.0 to $500.0 \mathrm{gal} /$ ton for HP, PSZ and PVAVS)

- COND-FLOW-TYPE(FIXED-FLOW;FIXED-FLOW,VARLABLE-FLOW for PSZ and PVAVS)

- COND-WTR-FLOW(3.0;1.0 to 5.0 Gpm for PSZ and PVAVS)

INDUC-MODE-SCH(I-M-SCH) u-name [Required only for TPIU systems.] 
$=$ SYSTEM-EQUIPMENT(S-EQ,50) [Continued on next page]

COOLING-CAPACITY(C-CAP $)(\dagger ; 0.0$ to $99999999.0 \mathrm{Btu} / \mathrm{hr})$

COOL-SH-CAP(C-S-C) $(\dagger ; 0.0$ to $99999999.0 \mathrm{Btu} / \mathrm{hr})$

COOLING-EIR(C-EIR) $(\dagger ; 0.0$ to $1.0 \mathrm{Btu} / \mathrm{Btu})$

HEATING-CAPACITY(H-CAP)(†;-99999999.0 to $0.0 \mathrm{Btu} / \mathrm{hr})$

HEATING-EIR(H-EIR) $(\dagger ; 0.0$ to $2.0 \mathrm{Btu} / \mathrm{Btu})$

- CONDENSER-TYPE(AIR-COOLED; Note: WATER-COOLED for PSZ, PVAVS, PVVT

and EVAP-PRECOOLED for PSZ, PMZS, PVAVS, PVVT, PTAC, RESYS)

- WS-ECONO-XEFF(0.60;0.10 to 1.00) (for HP, PSZ and PVAVS only)

FURNACE-HIR(F-HIR)(1.35;1.0 to $1.75 \mathrm{Btu} / \mathrm{Btu})$

FURNACE-AUX(F-A)(800.0;0.0 to $10,000.0 \mathrm{Btu} / \mathrm{hr})$

FURNACE-AUX-KW(F-A-KW)(0.0;0.0 to $1.0 \mathrm{~kW})$

$\mathrm{COIL}-\mathrm{BF}(\mathrm{C}-\mathrm{BF})(\dagger ; 0.0$ to $0.99 \mathrm{~cm} / \mathrm{cfm})$.

COOL-CTRL-RANGE(C-C-R) $\left(4.0 ; 0.0\right.$ to $\left.15.0^{\circ} \mathrm{F}\right)$

MIN-UNLOAD-RATIO(M-U-R)(0.25;0.0 to 1.0$)$

MIN-HGB-RATIO(M-H-R)(0.25;0.0 to 1.0$)$

MAX-COND-RCVRY(M-C-R $)(\dagger ; 0.0$ to 1.0$)$

CRANKCASE-HEAT $(\mathrm{C}-\mathrm{H})(t ; 0.0$ to $1.0 \mathrm{~kW})$

CRANKCASE-MAX-T(C-M-T) $\left(\dagger ; 0.0\right.$ to $\left.100.0^{\circ} \mathrm{F}\right)$

OUTSDE-FAN-ELEC $(\dagger ; 0.0$ to $20.0 \mathrm{~kW})$ changed in $2.1 \mathrm{E}$

OUTSIDE-FAN-T(O-F-T $)\left(\dagger ; 0.0\right.$ to $\left.200.0^{\circ} \mathrm{F}\right)$

OUTSIDE-FAN-MODE(O-F-M)(INTERMITTENT;INTERMITTENT, CONTINUOUS)

COMPRESSOR-TYPE(C-TYPE)(SINGLE-SPEED;SINGLE-SPEED, DUAL-SPEED)

HP-SUPP-HT-CAP(S-H-C)(t;-99999999.0 to $0.0 \mathrm{Btu} / \mathrm{hr})$

HP-SUPP-SOURCE(SUPP-S)(ELECTRIC;ELECTRIC,HOT-WATER, FURNACE,GAS-HYDRONIC) 1 changed in $2.1 \mathrm{E}$

MIN-HP-T(M-H-T) $\left(\dagger ;-30.0\right.$ to $\left.70.0^{\circ} \mathrm{F}\right)$

MAX-HP-SUPP-T(M-SUPP-T)(†;-30.0 to $\left.70.0^{\circ} \mathrm{F}\right)$

- DEFROST-TYPE(D-TYPE)(RESISTIVE;RESISTIVE,REVERSE-CYCLE)

- DEFROST-CTRL(D-CTRL)(TIMED;TIMED,ON-DEMAND)

- RESIST-CAP-RATIO(R-CAP-R)(.75;0.0 to 1.0$)$

DEFROST-T(D-T) $\left(40.0 ; 0.0\right.$ to $\left.70.0^{\circ} \mathrm{F}\right)$

- DEFROST-FRAC-FT(D-F-FT)(no default;u-name of a curve fit)

- EVAP-CL-TYPE(NONE;NONE,INDIRECT,INDIRECT/DIRECT)

- RES-EVAP-COOLER(NO;NO,YES) applies only to RESYS

- RES-EVAP-CL-CFM(no residential evap cooler;10.0 to $999999.0 \mathrm{cfm}$ ) applies only to RESYS

- EVAP-CL-KW(no evaporative cooler; 0.0 to $0.01 \mathrm{~kW} / \mathrm{cm}$ )

- EVAP-CL+M-SUP(TOGETHER;TOGETHER,SEPARATE)

- EVAP-CL+REC-RA(NO;NO,YES)

- DIRECT-EFF(0.85;0.1 to 1.0 fraction)

- INDIR-EFF(0.80;0.1 to 1.0 fraction)

- EVAP-CL-LIMIT-T $\left(199 ; 45.0\right.$ to $\left.200^{\circ} \mathrm{F}\right)$

- EVAP-CL-AIR(no evaporative cooler; 0.0 to $1.0 \mathrm{cfmOA} / \mathrm{cfmSUPPLY}$ )

$\dagger \quad$ System-dependent; see page 62, Index of System Types, for default values 
$=$ SYSTEM-EQUTPMENT(S-EQ,50) [Continued]

- DIRECT-EFF-FCFM u-name of quadratic curve

- INDIR-EFF-FCFM u-name of quadratic curve

- COOL-EIR-LS-FT u-name of bi-quadratic curve

- HEAT-EIR-LS-FT u-name of cubic curve

- COOL-RPM-LIMITS(C-R-LIM) ( $\dagger ; 100$ to 10,000 rpm)

COOL-CAP-FT(C-C-ET) u-name of bi-linear or bi-quadratic $\ddagger$

COOL-EIR-FT(C-E-FT) u-name of bi-linear or bi-quadratic $\ddagger$

COOL-EIR-FPLR(C-E-FP) u-name of linear, quadratic or cubic $\ddagger$

COOL-SH-FT(C-S-FT) u-name of bi-linear or bi-quadratic

- COIL-BF-FPLR(C-B-FPLR) u-name of quadratic curve

COIL-BF-FCFM(C-BF-FC) u-name of linear, quadratic or cubicf

COIL-BF-FT(C-BF-FT) u-name of bi-linear or bi-quadraticf

COOL-FT-MIN(C-FT-MIN) $\left(70.0 ; 0.0\right.$ to $\left.120.0^{\circ} \mathrm{F}\right)$

FURNACE-HIR-FPLR(F-H-FP) u-name of linear, quadratic or cubicł

HEAT-CAP-FT(H-C-FT) u-name of bi-linear or bi-quadratic $\ddagger$

HEAT-EIR-FT(H-E-FT) u-name of bi-linear or bi-quadratic $\ddagger$

HEAT-EIR-FPLR(H-E-FP) u-name of linear, quadratic or cubic

HR8-FWB1WB6(HR-FWB) (u-name of bi-linear or bi-quadratic)**

HR8PL-FWBIWB6(HRPL-FWB) (u-name of bi-linear or bi-quadratic)** .

QREG-FWB1WB6(QR-FWB) (u-name of bi-linear or bi-quadratic)**

QREGPL-FWB1WB6(QRPL-FWB) (u-name of bi-linear or bi-quadratic)**

REFG-KW-FTCOND (u-name of linear, quadratic, or cubic)(list of up to three)**

REFG-KW-FPLR (u-name of linear, quadratic, or cubic)(list of up to three)**

T8-FWB1WB6(T-FWB) (u-name of bi-linear or bi-quadratic)**

T8PL-FWB1WB6(TPL-FWB) (u-name of bi-linear or bi-quadratic)**

TWR-RFACT-FRT (u-name of bi-linear or bi-quadratic)(list of up to three)*

TWR-APP-FRFACT (u-name of bi-linear or bi-quadratic)(list of up to three)*

- DESC-GAS-FTW u-name of quadratic curve

- DESC-KW-FTW u-name of quadratic curve

DESC-T-FTW u-name of quadratic curve

DESC-W-FTW U-name of quadratic curve

† System-dependent; see page 62, Index of System Types, for default values

$\bullet=$ Required keyword $\quad-37-\quad \quad=$ Added/changed in 2.1E 
$=$ SYSTEM-EQUIPMENT(S-EQ,50) [Continued]

Keywords for HEAT-SOURCE = GAS-HEAT-PUMP

- COOL-CAP-FRPM(C-C-FRPM) u-name of quadratic curve

- COOL-CLOSS-FPLR u-name of quadratic curve

- COOL-CLOSS-MIN(C-C-MIN)(.8;0.0 to 1.0$)$

- COOL-EIR-FRPM(C-E-FRPM) u-name of quadratic curve

- COOL-WASTE-HEAT(C-W-HEAT) $(.7 ; 0.0$ to 1.0)

- COOI-WH-FRPM(C-W-FRPM) u-name of quadratic curve

- COOL-WH-FT(C-W-FT) u-name of quadratic curve

- HEAT-CAP-FRPM(H-C-FRPM) u-name of quadratic curve

- HEAT-RPM-LIMITS(H-R-LIM) ( $\dagger ; 100$ to $10,000 \mathrm{rpm})$

- HEAT-EIR-FRPM(H-E-FRPM) u-name of quadratic curve

- HEAT-WH-FT(H-W-FT) u-name of quadratic curve

- HEAT-WH-FRPM(H-W-FRPM) u-name of quadratic curve

- HEAT-CLOSS-FPLR u-name of quadratic curve

- HEAT-CLOSS-MIN(H-C-MIN) $(.8 ; 0.0$ to 1.0$)$

- HEAT-WASTE-HEAT(H-W-HEAT) $(.7 ; 0.0$ to 1.0)

- UNIT-PUMP-ELEC(U-P-ELEC)(.0017;0.0 to 1.0 Watts/Btu)

- UNIT-AUX-IKW(U-A-KW)(.02;0.0 to $1.0 \mathrm{~kW})$

- WASTE-HEAT-USE (SPACE-HEAT;SPACE-HEAT,SPACE-HEAT+DHW)

- OUTSIDE-FAN-CFLT u-name of quadratic curve

- OUTSIDE-FAN-HFLT u-name of quadratic curve

- EVAP-PCC-SCH(E-P-SCH) u-name

- EVAP-PCC-EFF(E-P-EFF) $(.8 ; 0.0$ to 1.0 watts/Btu $)$

- EVAP-PCC-ELEC(E-P-ELEC) $(.0017 ; 0.0$ to 1.0$)$

- SYSTEM-REPORT(YES;YES,NO) [Allows user to suppress unwanted reports.]

* Used only for PSZ refrigeration simulation; see the Supplemeni (2.1E) for default curves.

** Used only for SYSTEM-TYPE=PTGSD.

$\dagger$ System-dependent; see page 62, Index of System Types, for default values

$\ddagger$ See the Supplement (2.1E) for default curves. 


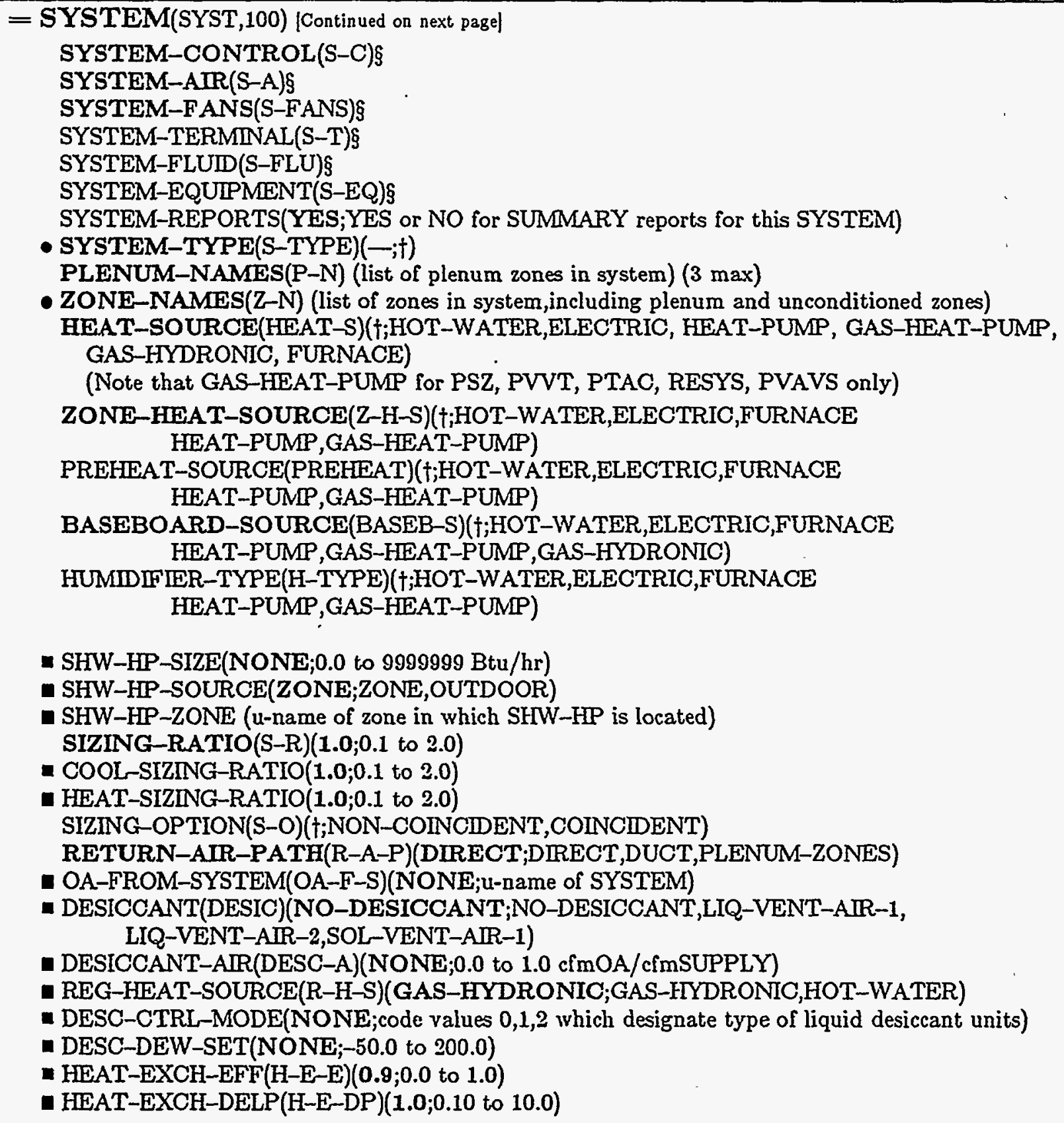

Note: REFG-type keywords used only for PSZ refrigeration simulation.

$\dagger$ System-dependent; see page 62, Index of System Types, for default values

§ Any keyword from these subcommands may be placed in the SYSTEM command 
= SYSTEM(SYST,100) [Continued]

Note: REFG-type keywords used only for PSZ refrigeration simulation.

REFG-SIZING-RAT(1.2;0.8 to 2.0)

REFG-COMP-CAP $(\$ ; 0.0$ to $99999999.0 \mathrm{Btu} / \mathrm{hr}$ ) (list of up to three)

REFG-COMP-EER( + ; 0.0 to $20.0 \mathrm{Btu} / \mathrm{W}$ ) (list of up to three)

REFG-COMP-GROUP(SEPARATE,SEPARATE,SEPARATE;

SEPARATE,COMMON)(list of up to three)

REFG-FAN-KW(0.105;0.0 to 100.0)

REFG-PUMP-KW(0.025;0.0 to 100.0$)$

REFG-MIN-COND-T $\left(60.0 ; 50.0\right.$ to $\left.110.0^{\circ} \mathrm{F}\right)$

REFG-COND-TYPE(WATER;WATER, AIR)

REFG-MAX-HTREC $(\ddagger ; 0.0$ to $99999999.0 \mathrm{Btu} / \mathrm{hr})$ [ $\ddagger$ Default: all compressor heat is recoverable.]

REFG-HTREC-UNTTS(YES,YES,YES;YES,NO) (list of up to three)

REFG-HTREC-GROUP(COMMON;COMMON,SEPARATE)

REFG-HTREC-T(90.0;80.0 to $\left.120.0^{\circ} \mathrm{F}\right)$

REFG-FAN-T $\left(30.0 ; 0.0\right.$ to $\left.100.0^{\circ} \mathrm{F}\right)$

The following metering keywords allow you to assign electric and fuel meters to specific end uses.

- MSTR-ELEC-METER(MSTR-EM) (M1;M1,M2,M3,M4,M5)

- MSTR-FUEL-METER(MSTR-FM) (M1;M1,M2,M3,M4,M5)

- LIGHT-ELEC-METER(LIGHT-EM) (MSTR-ELEC-METER;M1,M2,M3,M4,M5)

- TASK-ELEC-METER(TASK-EM) (MSTR-ELEC-METER;M1,M2,M3,M4,M5)

- EQUIP-ELEC-METER(EQUIP-EM) (MSTR-ELEC-METER;M1,M2,M3,M4,M5)

- SOURCE-ELEC-METER(SRC-EM) (MSTR-ELEC-METER;M1,M2,M3,M4,M5)

- HEAT-ELEC-METER(HEAT-EM) (MSTR-ELEC-METER;M1,M2,M3,M4,M5)

- COOL-ELEC-METER(COOL-EM) (MSTR-ELEC-METER;M1,M2,M3,M4,M5)

- HTREJ-ELEC-METER(HTREJ-EM) (MSTR-ELEC-METER;M1,M2,M3,M4,M5)

- AUX-ELEC-METER(AUX-EM) (MSTR-ELEC-METER;M1,M2,M3,M4,M5)

- VENT-ELEC-METER(VENT-EM) (MSTR-ELEC-METER;M1,M2,M3,M4,M5)

- REFG-ELEC-METER(REFG-EM) (MSTR-ELEC-METER;M1,M2,M3,M4,M5)

- SUPP-ELEC-METER(SUPP-EM) (MSTR-ELEC-METER;M1,M2,M3,M4,M5)

- DHW-ELEC-METER(DHW-EM) (MSTR-ELEC-METER;M1,M2,M3,M4,M5)

- SOURCE-FUEL-METER(SRC-FM) (M1;M1,M2,M3,M4,M5)

- HEAT-FUEL-METER(HEAT-FM) (MSTR-FUEL-METER;M1,M2,M3,M4,M5)

- COOL-FUEL-METER(COOL-FM) (MSTR-FUEL-METER;M1,M2,M3,M4,M5)

- SUPP-FUEL-METER(SUPP-FM) (MSTR-FUEL-METER;M1,M2,M3,M4,M5)

- DHW-FUEL-METER(DHW-FM) (MSTR-FUEL-METER;MI,M2,M3,M4,M5)

- ELEC-METER (M1;M1,M2,M3,M4,M5)

- FUEL-METER (M1;M1,M2,M3,M4,M5)

Note: All metering leywords listed under PLANT-ASSIGNMIENT command may be entered at the SYSTEM level.

If Default is linear with REFG-EVAP-T, 7.3 Btu/W at $25^{\circ} \mathrm{F}, 3.5 \mathrm{Btu} / \mathrm{W}$ at $-30^{\circ} \mathrm{F}$.

$\ddagger$ Defaults to (refrigeration equipment design load) $*$ (REFG-SIZING-RAT.) 
The Index of System Types is printed here for your convenience; see the tables (Applicability of Commands and Keywords to System Types) beginning on page 62.

\begin{tabular}{|ll|ll|}
\hline \multicolumn{3}{|c|}{ Index of System Types } \\
\hline CBVAV & Ceiling Bypass & PVAVS & Packaged DX VAV \\
DDS & Dual Duct & PVVT & Packaged DX Variable Volume \\
EVAP_COOL & Evaporation Cooling Unit & & Variable Temperature \\
FNSYS1 & (User-Defined) & RESVVT & Residential Variable Volume \\
FPFC & Four Pipe Fan Coil & & Variable Temperature \\
FPH & Panel Heating & RESYS & Furnace and Condensing Unit \\
FPIU & Four Pipe Induction & RHFS & Reheat \\
HP & Water/Air Heat Pump & SUM & Sums Zone Loads \\
HVSYS & Central Ventilation & SZCI & Ceiling Induction \\
MZS & Multizone & SZRH & Variable Temperature \\
PIU & Powered Induction Unit & TPFC & Two Pipe Fan Coil \\
PMZS & Packaged DX Multizone & TPIU & Two Pipe Induction \\
PSZ & Packaged DX Variable Temp & UHT & Unit Heater \\
PTAC & Packaged Air Conditioner & UVT & Classroom Unit Ventilator \\
PTGSD & Packaged Total Gas Solid Desiccant & VAVS & Variable Air Volume \\
\hline
\end{tabular}




\section{SUBR-FUNCTIONS}

BERNOU-1 $=*$ u-name

CFMINF-0 $=*$ u-name*

CFMINF $-1=* u-n a m e *$

CONCHN $={ }^{*} \mathrm{u}-$ name*

DAYCLS-1 $=*$ u-name*

DAYCLS-2 $=*$ u-name*

DAYCLS-3 $=$ *u-name*

DAYCLS-4 $=*$ u-name*

DAYCLS-5 =*u-name*

DAYCLS-6 $=*$ u-name ${ }^{*}$

DDSF-0 $=*$ u-name*

DDSF-1 $=* u-$ name*

DESFO-0=*u-name*

DESFO-1 =*u-name*

DESIGN =*u-name*

DESIND-0 $=* u-n a m e *$

DESIND-1 $=*$ u-name*

DESPIU $-0=*$ u-name*

DESPIU-1 =*u-name*

DKTEMP-0=*u-name*

DKTEMP-1 =*u-name*

DITTEMP-2 =*u-name*

DKTEMP-3=*u-name*

DOETRM-0 =*u-name*

DOETRM-1 =*u-name*

DOUBLE-O=*u-name*

DOUBLE-1 $={ }^{*} \mathrm{u}$-name*

EBAL-0 =*u-name*

$\mathrm{EBAL}-1=* u-n a m e *$

ECONO-1 =*u-name*

ECONO-2=*u-name*

ECONO-3=*u-name*

ECONO-4=*u-name*

FANPWR $=*$ u-name*
FCOIL-0 =**u-name*

FCOIL $-12=* u-n a m e *$

FCOIL-2Z =*u-name*

FCOIL-3 $={ }^{*} \mathrm{u}-\mathrm{name}$ *

FTDEV =*u-name*

FNSYS1-1=*u-name*

FNSYS1-2Z=*u-name*

FNSYS1-3Z=*u-name*

FNSYS1-4Z=*u-name*

FNSYS1-5 =*u-name*

FURNAC $={ }^{*} u-n a m e *$

$\mathrm{HE}={ }^{*} \mathrm{u}-\mathrm{name} \mathrm{e}^{*}$

HOURIN $=$ * u-name*

HPUNIT $={ }^{*} \mathrm{u}-\mathrm{name}{ }^{*}$

HTPUMP-0Z $={ }^{*}$ u-name*

HTPUMP-1Z =*u-name*

HTPUMP-2=*u-name*

HVUNIT $-0=*$ u-name*

HVUNTT-1Z=*u-name*

HVUNIT-2=*u-name*

HVUNIT-3=*u-name*

INDUC-0 $={ }^{*} u-$ name*

INDUC-1Z =*u-name*

INDUC-2 $=*^{*}$-name*

OPSTRT $=*$ u-name*

PANEL-OZ $=*$ u-name*

PANEL-1 $={ }^{*}$ u-name*

PIU-0=*u-name*

PIU-I=*u-name*

PTAC-0 =* u-name*

PTAC-1Z=*u-name*

PTAC-2 =*u-name*

RESYS-0 $={ }^{*} \mathrm{u}-\mathrm{name}{ }^{*}$

RESYS-1Z=*u-name*
RESYS-2Z =*u-name* RESYS-3Z=*u-name* RESYS- $4 Z=*$ u-name* RESYS-5 =*u-name* SDSF-O=*u-name* SDSF-1 =*u-name* SSBASB =*u-name* SSFCOR =*u-name* SUM-1==*u-name* SUM-2Z =*u-name* SUM-3Z =*u-name* SUM-4Z=*u-name* SUM-5 =*u-name* SZCI-0 $=*$ u-name* SZCI-1Z =*u-name* SZCI-2 $=*$ u-name* TDVPIU-0 $=*$ u-name* TDVPIU-1 =*u-name* TEMDEV-0=*u-name* TEMDEV-1=*u-name* TEMDEV-2=*u-name* TEMDEV-3=*u-name* TSOLVE-0 $=*$ u-name* TSOLVE-1 =*u-name* UNITH-0 $={ }^{*}$ u-name* UNITH-1Z $=$ *u-name* UNITH-2Z=*u-name* UNITH-3=*u-name* UNITV-0=*u-name* UNITV-1Z=*u-name* UNITV-2=*u-name* VARVOL-0=*u-name* VARVOL-1Z=*u-name* VARVOL-2=*u-name* VARVOL-3=*u-name* 


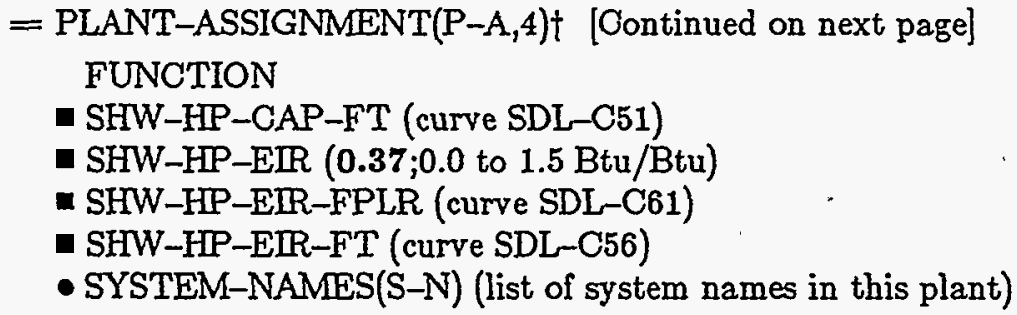

Note: HP-LOOP-HEATING used for HP only and HP-LOOP-COOLING used for PSZ and PVAVS when CONDENSER-TYPE=WATER-COOLED

- HP-LOOP-HEATING(FROM-SYSTEMS;FROM-PLANT,FROM-SYSTEMS)

- HP-LOOP-COOLING(FROM-SYSTEMS;FROM-PLANT,FROM-SYSTEMS)

- PLANT-REPORTS(YES;YES,NO) [Allows user to suppress unwanted reports.]

Note: The following cooling tower and loop pump keywords are used for the HP system and for PSZ and PVAVS water cooled condensers and water side economizers

- TWR-SIZE(automatically sized; 0.0 to 100.0 million $\mathrm{Btu} / \mathrm{hr}$ )

- TWR-NUM-CELLS(automatically determined t†; 0 to 100)

- TWR-EIR( + T; 0.0 to 10.0)

- TWR-SCH(u-name)

$0=$ tower not available,

$1=$ tower available,

$>1=$ tower available when ambient temperature exceeds this value;

if omitted, defaults to CIRC-PUMP-SCH

- TWR-SETPT-CTRL(FIXED; FLXED,WETBULB-RESET)

- TWR-SETPT-T(80.0; 32.0 to 100.0F)

- TWR-SETPT-SCH(u-name) [If omitted, defaults to TWR-SETPT-T]

- TWR-THROTTLE(10.0; 1.0 to $20.0 \mathrm{~F})$

- MIN-TWR-WTR-T(66.0; 32.0 to 100.0F)

- TWR-RESET-RATIO(0.29; 0.0 to 1.0$)$

- TWR-CELL-CTRL(MIN-CELLS; MIN-CELLS,MAX-CELLS)

- TWR-CAP-CTRL(ONE-SPEED-FAN; ONE-SPEED-FAN,FLUTD-BYPASS, TWO-SPEED-FAN,VARIABLE-SPEED-FAN)

- TWR-FAN-OFF-CFM(0.17; 0.0 to 1.0$)$

- TWR-FAN-LOW-CFM(0.50;0.0 to 1.0$)$ [Used only when TWR-CAP-CTRL = TWO-SPEED]

- TWR-FAN-LOW-ELEC $(0.18 ; 0.0$ to 1.0$)$ [Used only when TWR-CAP-CTRL = TWO-SPEED]

- TWR-MIN-FAN-SPEED(0.40; 0.0 to 1.0$)$ [Used only when TWR-CAP-CTRL = VARIABLE-SPEED-FAN]

- TWR-PUMP-HEAD(20.0;0.0 to $100.0 \mathrm{ft})$

- TWR-IMPELLER-EFF(0.77;0.0 to 1.0$)$

- TWR-MOTOR-EFF(0.90; 0.0 to 1.0$)$

- TWR-CELL-MAX-GPM(2.0; 1.0 to 3.0)

- TWR-CELL-MIN-GPM(0.33;0.2 to. 1.0$)$

- TWR-DESIGN-WETBULB(78.0; 30.0 to $85.0 \mathrm{~F})$

- TWR-DESIGN-APPROACH(7.0; 4.0 to 50.0F)

- TWR-FAN-FPLR(TWRFAN; u-name of cubic curve)

- TWR-GPM-FRA(GPMRA; u-name of bi-quadratic curve)

- TWR-GPM-FWB(GPMWB; u-name of bi-quadratic curve)

Note: LIKE keyword not allowed

$\dagger$ If this command is not used, the default PLANT-ASSIGNMENT is all systems described in input.

tt Based on a maximum of $15 \mathrm{MBtu} / \mathrm{hr}$ per cell.

Ht Defaults to a fan power of $0.0154 \mathrm{hp} / \mathrm{gpm}$; corresponds to $\mathrm{TWR}-\mathrm{EIR} \cong$ to $0.0105 \mathrm{Btu} / \mathrm{Btu}$ 
$=$ PLANT-ASSIGNMENT(P-A,4) $†$ [Continued]

CIRC-IMPELLER-EFF(0.77;0.0 to 1.0)

- CIRC-MOTOR-EFF(0.80;0.0 to 1.0)

- CIRC-HEAD(60.0;0.0 to 100.0 Feet)

- CIRC-PUMP-TYPE(FIXED-FLOW;FLED-FLOW,VARIABLE-FLOW)

- CIRC-MIN-PLR(0.50;0.0 to 1.0)

- CIRC-PUMP-FPLR (CIRC-PUMP-CURVE;u-name of linear or quadratic curve)

- CIRC-PUMP-SCH (on with any system fans;u-name of schedule)

- MAX-FLUID-T(120.0;50 to 120F) |unit high limit protection| oversides SYSTEM-FLUID inputs

- MIN-FLUID-T(50.0;40 to 80F) [unit low limit protection] provides SYSTEM-FLUID defaults

- FLUID-VOLUME(15.0;1.0 to 500.0 gal/ton) overrides SYSTEM-FLUD inputs.

- DHW-SIZE $(* ; 0.0$ to $1000 \mathrm{gal})$ *see keyword description

- DHW-HEAT-RATE $(* ; 0.0$ to $100000 \mathrm{Btu} / \mathrm{hr})$ *see keyword description

- DHW-TYPE(GAS;)

- DHW-EIR $(* ; 0.0$ to 3.0$) *$ see keyword description

DHW-LOSS $(.03 ; 0.0$ to 1.0$)$

- DHW-EIR-FT $(* * ;){ }^{* *}$ see curve default table, p.3.142

- DHW-HEAT-RATE-FT(**;) ** see curve default table, p.3.142

- DHW-EIR-FPLR(**; ** see curve default table, p.3.142

a DHW-PUMP-ELEC $(0.0 ; 0.0$ to $0.1 \mathrm{watt} / \mathrm{Btu})$

- DHW-PUMP-SCH $(-;)$

- DHW-HSUP-RATE $(* ; 0.0$ to $100000 \mathrm{Btu} / \mathrm{hr})$ *see keyword description

= DHW-HSTOR-RATE $(* ; 0.0$ to $100000 \mathrm{Btu} / \mathrm{hr})$ *see keyword description

Note: following BOILER-type keywords used only for HP loop simulation

- BOLER-SIZE(Automatically sized;-1000.0 to 0.0 Millions Btu/Hr)

- BOLLER-MIN-RATIO(0.25;0.0 to 1.0$)$

- BOILER-MAX-RATIO(1.20;1.0 to 2.0)

- BOLER-MAX-SCH(u-name) [If omitted defaults to BOLLER-MAX-RATIO]

a BOILER-EIR(0.02;0.0 to 10.0)

a BOILER-HLR(1.25;0.0 to 3.0)

- BOILER-HIR-FPLR(BLRHIR2;u-name of linear or quadratic)

- BOILER-TYPE(FUEL-BOILER;ELECTRIC-BOILER,FUEL-BOILER)

- BOILER-SCH(u-name) [If omitted defaults to CIRC-PUMP-SCH]

- BOILER-SET-POINT(85.0;32.0 to $100.0 \mathrm{~F})$

- BOILER-SET-SCH(u-name) [If omitted defaults to BOILER-SET-POINT]

- BOILER-THROTTLE(10.0;1.0 to 20.0 F)

- BOILER-LOSS(0.02;0.0 to 1.0 fraction of capacity of electric boiler)

The following keywords allow you to input building energy resources that do not contribute to the building internal loads. These replace keywords that were formerly entered under BUILDING-RESOURCE in LOADS. Metering keywords allow you to assign electric and fuel meters to specific end uses:

- MSTR-ELEC-METER(MSTR-EM) (M1;M1,M2,M3,M4,M5)

- MSTR-FUEL-METER(MSTR-FM) (M1;M1,M2,M3,M4,M5)

- LIGHT-ELEC-METER(LIGHT-EM) (MSTR-ELEC-METER;M1,M2,M3,M4,M5)

- TASK-ELEC-METER(TASK-EM) (MSTR-ELEC-METER;M1,M2,M3,M4,M5)

- EQUIP-ELEC-METER(EQUIP-EM) (MSTR-ELEC-METER;M1,M2,M3,M4,M5) 
$=$ PLANT-ASSIGNMENT(P-A,4)† [Continued]

- SOURCE-ELEC-METER(SRC-EM) (MSTR-ELEC-METER;M1,M2,M3,M4,M5)

- HEAT-ELEC-METER(HEAT-EM) (MSTR-ELEC-METER;M1,M2,M3,M4,M5)

- COOL-ELEC-METER(COOL-EM) (MSTR-ELEC-METER;M1,M2,M3,M4,M5)

- HTREJ-ELEC-METER(HTREJ-EM) (MSTR-ELEC-METER;M1,M2,M3,M4,M5)

- AUX-ELEC-METER(AUX-EM) (MSTR-ELEC-METER;M1,M2,M3,M4,M5)

- VENT-ELEC-METER(VENT-EM) (MSTR-ELEC-METER;M1,M2,M3,M4,M5)

- REFG-ELEC-METER(REFG-EM) (MSTR-ELEC-METER;M1,M2,M3,M4,M5)

- SUPP-ELEC-METER(SUPP-EM) (MSTR-ELEC-METER;M1,M2,M3,M4,M5)

- DHW-ELEC-METER(DHW-EM) (MSTR-ELEC-METER;M1,M2,M3,M4,M5)

- SOURCE-FUEL-METER(SRC-FM) (M1;M1,M2,M3,M4,M5)

- HEAT-FUEL-METER(HEAT-FM) (MSTR-FUEL-METER;M1,M2,M3,M4,M5)

- COOL-FUEL-METER(COOL-FM) (MSTR-FUEL-METER;M1,M2,M3,M4,M5)

- SUPP-FUEL-METER(SUPP-FM) (MSTR-FUEL-METER;M1,M2,M3,M4,M5)

- DHW-FUEL-METER(DHW-FM) (MSTR-FUEL-METER;M1,M2,M3,M4,M5)

- INT-FUEL-BTU/HR(I-F-BTU) (0.0;0.0 to 10,000,000 Btu/hr)

- INT-FUEL-SCH(I-F-SCH) (u-name)

- INT-FUEL-METER(I-F-M) (MSTR-FUEL-METER;M1,M2,M3,M4,M5)

- INT-FUEL-POWER (0.0;0.0 to 10,000,000 Btu/hr)

- EXT-FUEL-BTU/HR(E-F-BTU) $(0.0 ; 0.0$ to $10,000,000 \mathrm{Btu} / \mathrm{hr})$

- EXT-FUEL-SCH(E-F-SCH) (u-name)

- EXT-FUEL-METER(E-F-M) (MSTR-FUEL-METER;M1,M2,M3,M4,M5)

- EXT-FUEL-POWER (0.0;0.0 to 10,000,000 Btu/hr)

- INT-ELEC-IKW(I-E-K) $(0.0 ; 0.0$ to $1000 \mathrm{~kW})$

- INT-ELEC-SCH(I-E-SCH) (u-name)

- INT-ELEC-METER(I-E-M) (MSTR-ELEC-METER;M1,M2,M3,M4,M5)

- EXT-ELEC-KW(E-E-K) $(0.0 ; 0.0$ to $1000 \mathrm{~kW})$

- EXT-ELEC-SCH(E-E-SCH) $=$ (u-name)

- EXT-ELEC-METER(E-E-M) (MSTR-ELEC-METER;M1,M2,M3,M4,M5)

- EXT-LIGHT-IKW(E-L-KW) $(0.0 ; 0.0$ to $1000 \mathrm{~kW})$

- EXT-LIGHT-SCH(E-L-SCH) (u-name)

- EXT-LIGHT-METER(E-L-M) (MSTR-ELEC-METER;M1,M2,M3,M4,M5)

- DHW-GAL/MIN (DHW-GPM)(0.0; 0.0 to $10,000 \mathrm{gal} / \mathrm{min})$

- DHW-FLOW' (same as DHW'-GAL/MIN)(

- DHW-SCH (u-name)

- DHW-INLET-T-SCH (u-name)[defaults to ground temperatures from weather file]

- DHW-SUPPLY-T (140.0; 70.0 to $200.0 \mathrm{~F})$

- PROCESS-HW-BTU/HR(HW-BTU) (0.0;0.0 to 10,000,000 Btu/hr)

- PROCESS-HW-SCH(HW-SCH) (u-name)

- PROCESS-HW-POWER (0.0;0.0 to 10,000,000 Btu/hr)

- PROCESS-CHW-BTU/HR(CHW-BTU) $(0.0 ; 0.0$ to 10,000,000 Btu/hr)

- PROCESS-CHW-SCH (u-name)

- PROCESS-CHW-POWER $(0.0 ; 0.0$ to $10,000,000 \mathrm{Btu} / \mathrm{hr})$ 
SYSTEMS-REPORT(S-R,1)†

VERIFICATION(V)(SV-A;SV-A,SV-B,REPORT-ONLY) (list)

SUMMARY(S)(SS-A;SS-A,SS-B,...,SS-Q,REFG,ALL-SUMMARY) (list)

REPORT-FREQUENCY(R-F)(HOURLY;HOURLY,DAIIY,MONTHLY,YEARLY)

HOURLY-DATA-SAVE(H-D-S)(NO;BINARY,FORMATTED) added in 2.1D, changed in 2.1E

Note: See pages 116-117 for a brief description and Áppendix C

of the Supplement (2.1E) for a full description of all reports.

$t$ The total number of reports generated may not exceed 200.

$=$ REPORT-BLOCIK(R-B,64)

- VARIABLE-TYPE(V-T)(一;GLOBAL,U-name of ZONE,

u-name of SYSTEM, u-name of PLANT-ASSIGNMENT,END-USE,LOADS-DATA)

- VARIABLE-LIST(V-L)(-;code-numberst)(list)

$\dagger$ For code-number lists, see Appendix A in the Supplement (2.1E).

$=$ HOURLY-REPORT(H-R,16)

- REPORT-SCHEDULE(R-SCH) u-name

- REPORT-BLOCIK(R-B) (list of u-names of Report Blocks) OPTION(O)(PRINT;PRINT,PLOT $†, B I N A R Y-F L E)$

+ For PLOT option see LOADS for additional required and optional keywords.

END Required at end of Systems input

FUNCTION(100)

$\operatorname{ASSIGN(100)}$

CALCULATE(100) Required to do FUNCTION calculation

Note: Follow this command (after the terminator) with the FORTRAN-like statements that define the desired function. As in standard FORTRAN, statement numbers must appear in columns 1-5, column 6 is used to designate a statement continuation, and statements must begin in or after column 7 and end before 72. The last statement must be END.

See page 1.10 of the Supplement (2.1E) for a list of valid FORTRAN declarative and executable statements.

END-FUNCTION(100) Required at end of FUNCTION input

\section{COMPUTE SYSTEMS Required to do SYSTEMS simulation}

SAVE-FILES Use only if saving SYSTEMS output for subsequent runs

STOP Use only if want BDL and simulation to stop here

- = Required keyword

$-46-$

$=$ Added/changed in 2.1E 


\section{PLANT SUMMARY}

(Note: LIKE keyword not allowed in PLANT input except in DAY-ASSIGN-SCH, DAY-SCHEDULE, and WEEIK-SCHEDULE]

\section{INPUT PLANT Required for Plant input} INPUT-UNITS(ENGLISH;ENGLISH,METRIC)

OUTPUT-UNITS(ENGLISH;ENGLISH,METRIC)

PARAMETRIC-INPUT PLANT

INPUT-UNITS(ENGLISH;ENGLISH,METRIC)

OUTPUT-UNITS(ENGLISH;ENGLISH,METRIC)

[Note: Replaces INPUT PLANT for parametric runs]

\section{TITLE $(5)$}

See LOADS

\section{ABORT}

(only needed when overriding value input in LOADS)

\section{DIAGNOSTIC(LIST)}

(only needed when overriding value input in LOADS)

\section{PARAMETER(DEFINE)}

See LOADS

$$
=\text { CURVE-FIT(C-F,100) }
$$

See SYSTEMS

$=$ DAY-ASSIGN-SCH(D-A-SCH,300 minus the number of D-SCH's) See LOADS $\dagger$.

+ In place of fractional values, D-A-SCH takes u-name of LOAD-ASSIGNMENT.

$=\mathrm{DAY}-\mathrm{SCHEDULE}(\mathrm{D}-\mathrm{SCH}, 300)$ See LOADS

$=$ WEEK-SCHEDULE(W-SCH,200)

See LOADS 
$=$ SCHEDULE(SCH,100) [Note: LIKE keyword not allowed] See LOADS

u-name $=$ PLANT-ASSIGNMENT(P-A, 1)

[Note: $u-n a m e$ must be the $u-n a m e$ of a $P \sim A$ in SYSTEMS; if P-A is defined in SYSTEMS, it must be defined in PLANT.]

= PLANT-EQUIPMENT(P-E,60) [Six PLANT-EQUIPMENT instructions are allowed for each equipment type, so that up to six different sizes may be specified for each type. Exceptions are cooling towers, and hot and cold water tanks. Only one of each of these may be specified.]

- TYPE (-;†)

$\operatorname{SIZE}(0.0 ;-1,000.0$ to $100.0 \mathrm{MBtu} / \mathrm{hr})$

INSTALLED-NUMBER(I-N)(1;1 to 10) (all integers)

Note: For a cooling tower, INSTALLED-NUMBER is the number of cells.

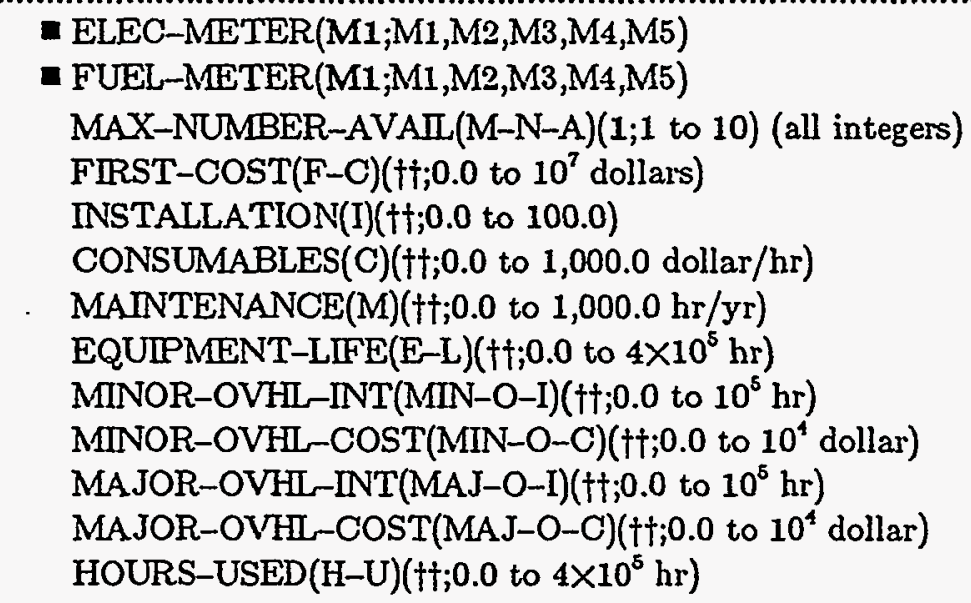

[Note: At least one PLANT-EQUIPMENT command is required; TYPE must be the first keyword listed] † Allowed TYPE code-words are:
ABSORG-CHIR
ABSOR 1-CHLR
ABSOR2-CHLR
CTANK-STORAGE
DBUN-CHLR
DHW-HEATER
DIESEL-GEN
ELEC-DHW-HEATER
ELEC-HW-BOILER
ELEC-STM-BOILER
ENG-CHLR

H See the following table for Equipment Cost Reference Default Values.

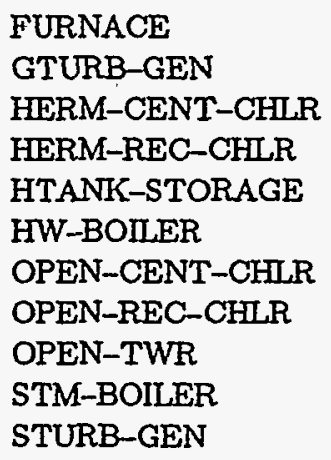




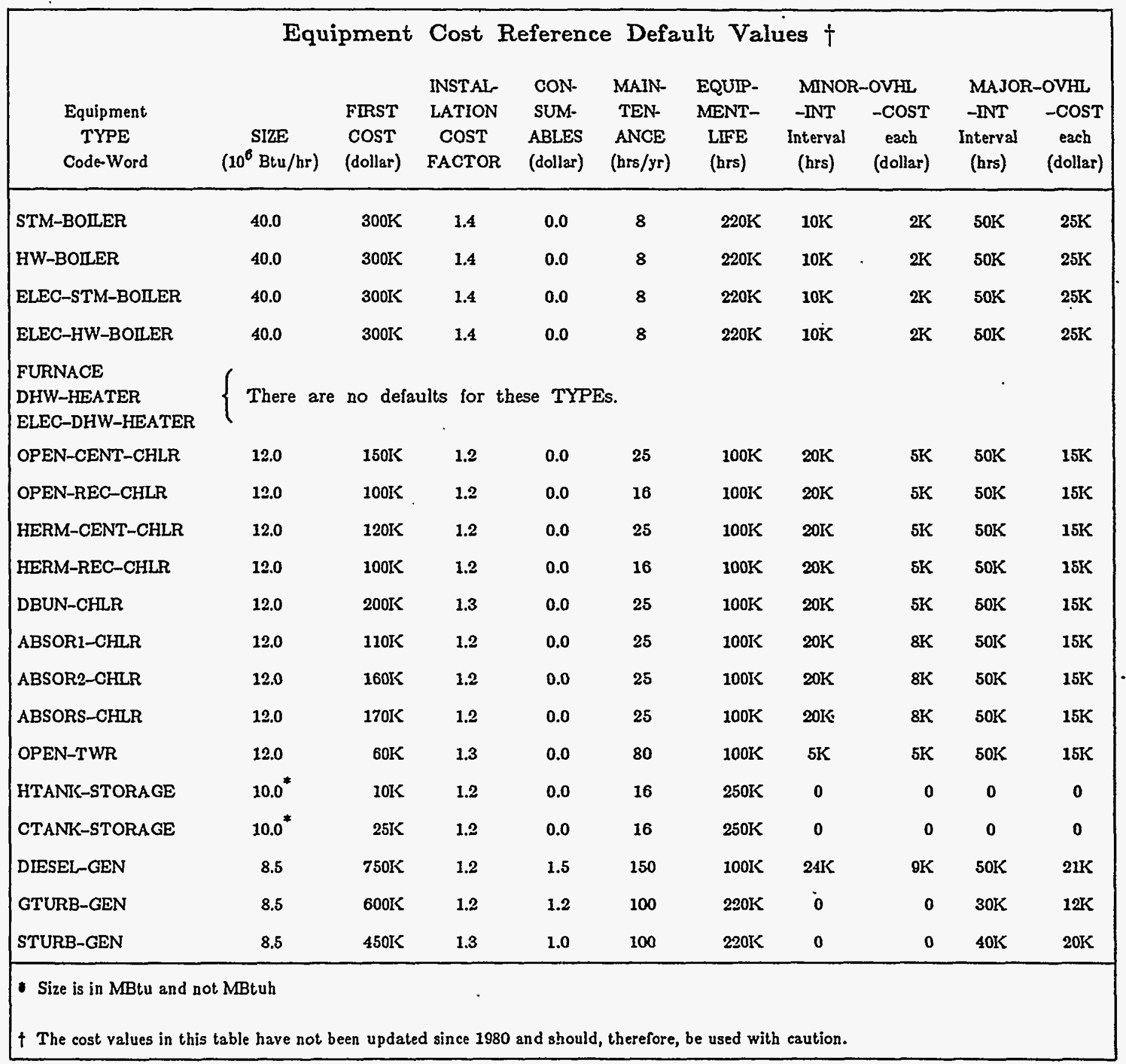


PART-LOAD-RATIO(P-I-R,25) [One PART-LOAD-RATIO instruction may be used for each equipment type.]

- TYPE $\left(-;^{*}\right)$ [* Takes same code-words as TIPE in PLANT-EQUTPMENT.]

MIN-RATIO(MIN-R) $(\ddagger ; 0.0$ to 1.0$) \ddagger$ see table below for default values

MAX-RATIO(MAX-R)( $;$ 1.0 to 2.0$) \ddagger$ see table below for default values

OPERATING-RATIO(O-R)( $\ddagger ; 0.0$ to 2.0$) \ddagger$ see table below for default values

ELEC-INPUT-RATIO(E-I-R)( $\ddagger ; 0.0$ to 10.0$) \ddagger$ see table below for default values

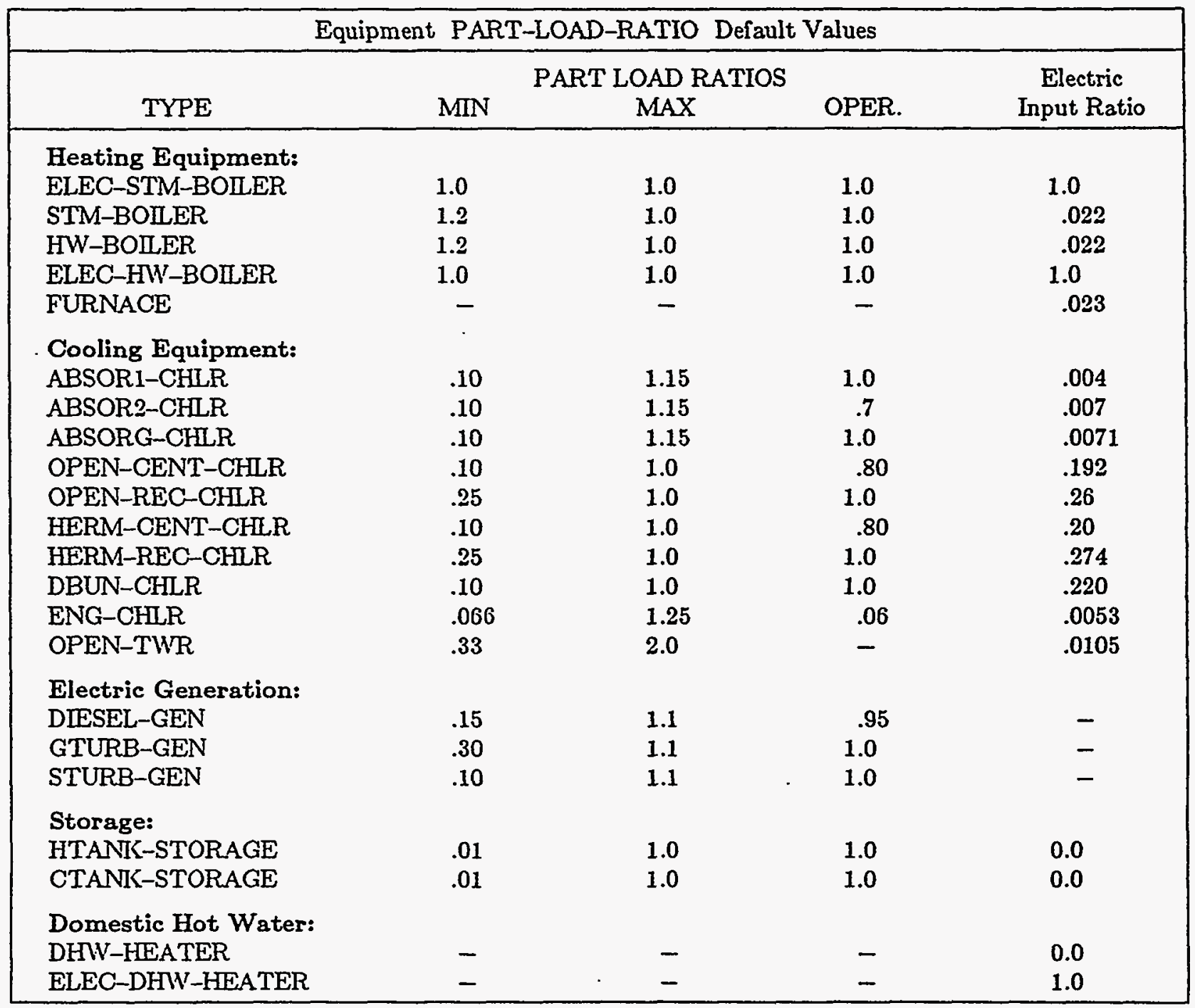


PLANT-PARAMETERS(P-P,1) [Continued on the next page]

Automatic Sizing of Plant Heating and Cooling Equipment:

- PLANT-SIZING-BY(DD-IF-PRESENT;DD-IF-PRESENT, WEATHER)

Chillers:

CHILLER-CONTROL(DEMAND-ONLY;DEMAND-ONLY,STANDBY)

OPEN-CENT-COND-TYPE(TOWER;TOWER,AIR)

OPEN-REC-COND-TYPE(TOWER:TOWER,AIR)

HERM-CENT-COND-TYPE(TOWER;TOWER,AIR)

HERM-REC-COND-TYPE(TOWER;TOWER,AIR)

OPEN-CENT-COND-PWR(0.3;0.0 to $1.0 \mathrm{Btu} / \mathrm{Btu})$ changed in $2.1 \mathrm{E}$

OPEN-REC-COND-PWR(0.03;0.0 to $1.0 \mathrm{Btu} / \mathrm{Btu})$

HERM-CENT-COND-PWR(0.3;0.0 to $1.0 \mathrm{Btu} / \mathrm{Btu})=$ changed in $2.1 \mathrm{E}$

HERM-REC-COND-PWR(0.03;0.0 to $1.0 \mathrm{Btu} / \mathrm{Btu})$

OPEN-CENT-UNL-RAT(0.1;0.0 to 1.0$)$

OPEN-REC-UNL-RAT(0.25;0.0 to 1.0$)$

HERM-CENT-UNL-RAT(0.1;0.0 to 1.0$)$

HERM-REC-UNL-RAT $(0.25 ; 0.0$ to 1.0$)$

OPEN-CENT-MOTOR-EFF(0.8;0.0 to 1.0$)$

OPEN-REC-MOTOR-EFF(0.9;0.0 to 1.0$)$

ABSOR1-HIR(1.6;0.0 to 3.0$)$

ABSOR2-HIR(1.0;0.0 to 3.0$)$

ABSORG-HIR(1.0; 0.0 to 3.0$)$

ABSORG-HCAPR(1.0;0.0 to 2.0)

ABSORG-HEAT-XEFF $(0.8 ; 0.1$ to 1.0$)$

ABSOR-TO-TWR-WTR(3.0;0.0 to $100.0 \mathrm{gpm} /$ ton)

DBUN-TO-TWR-WTR(3.0;1.0 to $5.0 \mathrm{gpm} /$ ton $)$

DBUN-COND-T-ENT(85.0;60.0 to $\left.100.0^{\circ} \mathrm{F}\right)$

DBUN-COND-T-REC $\left(105.0 ; 80.0\right.$ to $\left.120.0^{\circ} \mathrm{F}\right)$

DBUN-CAP-COR-REC (-;0.0 to 1.0$)$

DBUN-EIR-COR-REC(-;1.0 to 2.0)

DBUN-UNL-RAT-DES(0.1;0.0 to 1.0$)$

DBUN-UNL-RAT-REC $(0.3 ; 0.0$ to 1.0$)$

DBUN-HT-REC-RAT $(0.85 ; 0.0$ to 1.0$)$

- DESICCANT-XEFF(0.8;0.1 to $1.0 \mathrm{Btu} / \mathrm{Btu})$

ENG-CH-COP(1.4; 0.1 to 3.0$)$

ENG-CH-REC-EFF(.519; 0.1 to 1.0$)$

ENG-CH-COND-TYPE(TOWER;TOWER;AIR)

ENG-CH-IDLE-RAT $(.3125 ; 0.0$ to 1.0$)$

DBUN-MIN-HEAT(0.0;0.0 to $\left.10^{6} \mathrm{MBtu}\right)$

COMP-TO-TWR-WTR(3.0;1.0 to $5.0 \mathrm{gpm} /$ ton $)$

MIN-COND-AIR-T(65.0;0.0 to 100.0\%)

CHILL-WTR-T(44.0;32.0 to $\left.80.0^{\circ} \mathrm{F}\right)$

CHILL-WTR-THROTTLE $\left(2.5 ; 1.0\right.$ to $\left.15.0^{\circ} \mathrm{F}\right)$

* The options are: DIESEL-OIL,NATURAL-GAS,FUEL-OL,LPG,COAL,METHANOL,BIOMASS. 
PLANT-PARAMETERS(P-P,1) [Continued]

Boilers:

BOILER-CONTROL(DEMAND-ONLY;DEMAND-ONLY,STANDBY)

STM-BOILER-HIR(1.3;0.0 to 3.0)

HW-BOILER-HIR(1.25;0.0 to 3.0$)$

E-STM-BOLER-LOSS $(0.02 ; 0.0$ to 1.0$)$

E-HW-BOILER-LOSS(0.02;0.0 to 1.0)

Domestic Hot Water Heaters:

ELEC-DHW-LOSS(0.03;0.0 to $1.0 \mathrm{Btu} / \mathrm{Btu})$

DHW-HIR(1.39;0.0 to 3.0$)$

Gas Furnace:

FURNACE-HIR(1.35;0.0 to 3.0$)$

FURNACE-AUX(800.0;0.0 to $2,000.0 \mathrm{Btu} / \mathrm{hr})$

Thermal Energy Storage:

- TES-TYPE(NO-TES;NO-TES,ICE-ON-COIL,ICE-HARVESTER,BRINE, ICE-SLURRY,EUTECTIC)

- TES-PRIORITY(STORAGE;STORAGE,CHLLER)

- PERCENT-STORED(100.0;0.0 to $100 \%$ of daily integrated load)

- HOURS-CHARGING(12.0;0.0 to 24.0 hours)

- HOURS-DISCHARGING(12.0;0.0 to 24.0 hours)

- COMP-MODE-DCHG(RATED-T;RATED-T,LOW-T,DEM-LIM+RATED-T, DEM-LM+LOW-T)

- PER-COMP-REDUCT/F(2.0;0.0 to $100 \%$ of chiller rated capacity per $\left.{ }^{\circ} \mathrm{F}\right)$

- REFRIG-T-AT-PC $\left(26.0 ; 10.0\right.$ to $\left.100.0^{\circ} \mathrm{F}\right)$

- COMP-KW/TON-START(0.96;0.0 to $10.0 \mathrm{~kW} /$ ton)

- COMP-IKW/TON-END(0.96;0.0 to $10.0 \mathrm{~kW} /$ ton $)$

- EVAP-DELTA-T(16.0;0.0 to 40.0 $\mathrm{F})$

- PUMP+AUX-KW(0.0;0.0 to $10.0 \mathrm{~kW})$

- PUMP+AUX-SCH(u-name of schedule)

- ICE-HARVEST-RATIO(0.75;0.0 to 1.0$)$

- DELAY-CHARGE-HOUR(first hour in COOL-STORE-SCH;0 to 12 hours) 
PLANT-PARAMETERS(P-P,1) /Continued on the next page|

Towers:

- TWR-DESIGN-WETBULB(78.0; 30.0 to 85.0F)

- TWR-DESIGN-APPROACH(7.0; 4.0 to $50.0 \mathrm{~F})$

- TWR-DESIGN-RANGE(10.0; 4.0 to $20.0 \mathrm{~F})$

- TWR-SETPT-CTRL(FLXED; FLXED,WETBULB-RESET)

- TWR-SETPT-T(80.0; 32.0 to $100.0 F)$

- TWR-THROTTLE (5.0; -20.0 to 20.0F)

MIN-TWR-WTR-T (68.0; 32.0 to $100.0 \mathrm{~F})$

- TWR-RESET-RATIO $(0.28 ; 0.0$ to 1.0$)$

- TWR-CELI-CTRL(MIN-CELLS; MIN-CELLS,MAX-CELLS)

- TWR-CAP-CTRL(ONE-SPEED-FAN; ONE-SPEED-FAN,FLUID-BYPASS, TWO-SPEED-FAN,VARIABLE-SPEED-FAN)

TWR-FAN-OFF-CFM $(0.18 ; 0.0$ to 1.0$)$

TWR-FAN-LOW-CFM(0.50; 0.0 to 1.0$)$

Used only when TWR-CAP-CTRL $=$ TWO-SPEED

- TWR-FAN-LOW-ELEC $(0.16 ; 0.0$ to 1.0$)$

Used only when TWR-CAP-CTRL $=$ TWO-SPEED

- TWR-MIN-FAN-SPEED(0.40; 0.0 to 1.0)

Used only when TWR-CAP-CTRL = VARIABLE-SPEED-FAN

- TWR-PUMP-HEAD $(\mathbf{6 0 . 0} ; 0.0$ to $100.0 \mathrm{ft})$

TWR-IMPELLER-EFF(0.77; 0.0 to 1.0$)$

TWR-MOTOR-EFF(0.90; 0.0 to 1.0$)$

- DIRECT-COOL-MODE(NOT-AVAILABLE;NOT-AVAILABLE,STRAINER-CYCLE, THERMO-CYCLE)

DC-MAX-OAT(65.0; 35.0 to 70.0F)

DC-MAX-CHLL-WTR-T(50.0; 30.0 to 60.0F)

- DC-TWR-WTR-SETPT(45.0 if STRAINER-CYCLE, 40.0 if THERMO-CYCLE; 38.0 to 50.0F)

- DIRECT-COOL-SCH(no default) u-name

DIRECT-COOL-KW(0.0 if STRAINER-CYCLE, 0.02 if THERMO-CYCLE; 0.0 to $1.0 \mathrm{~kW} /$ ton) 


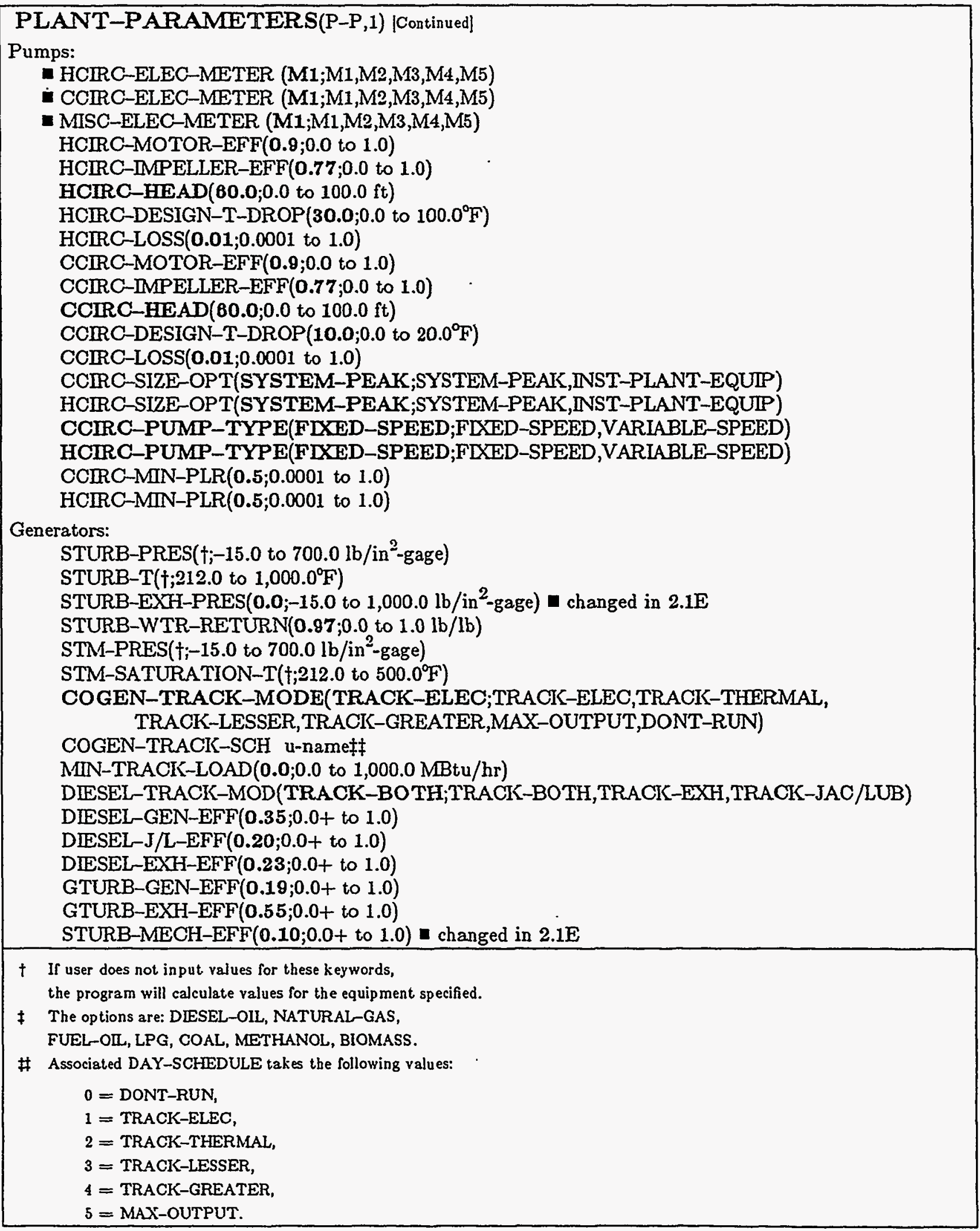


EQUIPMENT-QUAD(E-Q,1) [See the Reference Manual (2.1A) Chap. $V$, Table 6 for default curves.] STM-BOILER-HIR-FPLR u-name of linear or quadratic HW-BOILER-HIR-FPLR u-name of linear or quadratic FURNACE-HIR-FPLR u-name of linear or quadratic DHW-HIR-FPLR u-name of linear or quadratic OPEN-CENT-CAP-FT u-name of bi-linear or bi-quadratic OPEN-CENT-EIR-FT u-name of bi-linear or bi-quadratic OPEN-CENT-EIR-FPLR u-name of linear or quadratic OPEN-REC-CAP-FT u-name of bi-linear or bi-quadratic OPEN-REC-EIR-FT u-name of bi-linear or bi-quadratic OPEN-REC-EIR-FPLR u-name of linear or quadratic HERM-CENT-CAP-FT u-name of bi-linear or bi-quadratic HERM-CENT-EIR-FT u-name of bi-linear or bi-quadratic HERM-CENT-EIR-FPLR u-name of linear or quadratic HERM-REC-CAP-FT u-name of bi-linear or bi-quadratic HERM-REC-EIR-FT u-name of bi-linear or bi-quadratic HERM-REC-EIR-FPLR u-name of linear or quadratic ABSOR1-CAP-FT u-name of bi-linear or bi-quadratic ABSOR1-HIR-FT u-name of bi-linear or bi-quadratic ABSOR1-HIR-FPLR u-name of linear or quadratic [ See the Supplement (2.1E) for default curves.] ABSOR2-CAP-FT u-name of bi-linear or bi-quadratic ABSOR2-HIR-FT u-name of bi-linear or bi-quadratic ABSOR2-HIR-FPLR u-name of linear or quadratic [See the Supplement (2.1E) for default curves.] ABSORG-CAP-FT u-name of bi-linear or bi-quadratic ABSORG-HIR-FT u-name of bi-linear or bi-quadratic ABSORG-HIR-FPLR u-name of linear or quadratic [See the Supplement (2.1E) for defaull curves.] ABSORG-HIR1-FTI u-name of linear or quadratic ABSORG-HCAP-FQC u-name of linear or quadratic ENG-CH-CAP-FT u-name of linear or quadratic ENG-CH-COP-FPLR1 u-name of linear or quadratic ENG-CH-COP-FPLR2 u-name of linear or quadratic ENG-CH-COP-FT u-name of linear or quadratic ENG-CH-HREJ-FPLR u-name ố linear or quadratic ENG-CH-HREJ-FT u-name of linear or quadratic ENG-CH-COP-FPLRS u-name of linear or quadratic ENG-CH-COP-FTS u-name of linear or quadratic DBUN-CAP-FT u-name of bi-linear or bi-quadratic DBUN-EIR-FT u-name of bi-linear or bi-quadratic DBUN-EIR-FPLR u-name of linear or quadratic DBUN-GAP-FTRISE u-name of linear or quadratic DBUN-EIR-FTRISE u-name of linear or quadratic - TWR-FAN-FPLR u-name of cubic [See the Supplement (2.1E) for default curves.] - TWR-GPM-FRA u-name of bi-quadratic [See the Supplemenl (R.1E) for default curves.] - TWR-GPM-FWB u-name of bi-quadratic [See the Supplement (2.1E) for default curves.]

- TC-CHLR-CAP-FT u-name of bi-linear or bi-quadratic [See the Supplement (R.1E) for default curves.] DIESEL-I/O-FPLR u-name of linear or quadratic [See the Supplement (2.1E) for defsult curves.] DIESEL-EXH-FPLR u-name of linear or quadratic [See the Supplement (2.1E) for default curves.] DIESEL-JCLB-FPLR u-name of linear or quadratic [See the Supplement (2.1E) for default curves.] DIESEL-TEX-FPLR u-name of linear or quadratic [See the Supplement (2.1E) for detault curves.] GTURB-CAP-FT u-name of linear or quadratic [See the Supplement (2.1E) for default curves.] GTURB-I/O-FPLR u-name of linear or quadratic [See the Supplement (2.1E) for default curves.] GTURB-EXH-FPLR u-name of linear or quadratic [See the Supplement (2.1E) for default curves.] 
EQUIPMENT-QUAD(E-Q,1) |Continued]

GTURB-TEX-FPLR u-name of linear or quadratic [See the Supplement (2.IE) for default curves.] STURB-ENTH-FPIX u-name of bi-linear or bi-quadratic [See the Supplement (2.1E) for default curves.] STURB-I/O-FPLR u-name of linear or quadratic [See the Supplement (2.1E) for default curves.]

- DIESEL-JAC-FPLR u-name of linear or quadratic [ See the Supplement (2.1E) for default curves.]

- DIESEL-LUB-FPLR u-name of linear or quadratic [ See the Supplement (2.1E) for default curves.]

- DIESEL-STACK-FU u-name of linear or quadratic [See the Supplement (2.1E) for default curves.]

- GTURB-STACK-FU u-name of linear or quadratic [See the Supplement (2.1E) for default curves.]

- GTURB-EXH-FTO u-name of linear or quadratic [See the Supplement (2.1E) for default curves.]

- GTURB-I/O-FTO u-name of linear or quadratic [See the Supplement (2.1E) for default curves.]

- GTURB-TEX-FTO u-name of linear or quadratic [ See the Supplement (2.1E) for default curves.]

HEAT-RECOVERY(HEAT-R;1)

SUPPLY-1(S-1)(DBUN-CHLR; $†$ )

DEMAND-1(D-1)(SPACE-HEAT; $\dagger)$

SUPPLY-2(S-2)(-;

DEMAND-2(D-2)(-; $)$

:

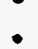

SUPPLY-5(S-5)(-; $\dagger$ )

DEMAND-5(D-5)(-;

- DIESEL-TRACK-MOD(TRACK-BOTH;TRACK-BOTH,TRACK-EXH,TRACK-JAC/LUB)

- COGEN-TRACK-MODE(TRACK-ELEC;TRACK-ELEC,TRACK-THERMAL,

TRACK-LESSER,TRACK-GREATER,MAX-OUTPUT,DONT-RUN)

- COGEN-TRACK-SCH u-name

- DBUN-MIN-HEAT(0.0;0.0 to $\left.10^{6} \mathrm{MBtu}\right)$

$\dagger$ Each keyword can have a list of up to three code-words of the appropriate type from the following: ABSOR1-CHLR (DEMAND), ABSOR2-CHLR (DEMAND), DBUN-CHLR (SUPPLY), DIESEL-GEN (SUPPLY), DIESEL-JACKET (SUPPLY), ENG-CHLR (SUPPLY), GTURB-GEN (SUPPLY), HTANK-STORAGE (SUPPLY,DEMAND), PROCESS-HEAT (DEMAND), REGEN-HEATH (DEMAND), SPACE-HEAT (DEMAND), STURB-GEN (SUPPLY)

it for use of this code-word, see "Add-On (Integrated) Desiccant Cooling", Supplement (2.1E), p.3.76.

\$ Associated DAY-SCHEDULE takes the following values: $0=$ DONT-RUN, $1=$ TRACK-ELEC, $2=$ TRACK-THERMAL, $3=$ TRACK-LESSER, $4=$ TRACK-GREATER, $5=$ MAX-OUTPUT.

$=$ LOAD-ASSIGNMENT(L-A,50)

- TYPE(-;HEATING,COOLING,ELECTRICAL) OPERATION-MODE(O-M)(RUN-NEEDED;RUN-NEEDED,RUN-ALL)

- LOAD-RANGE(L-R)(一;0.0 to $1,000.0 \mathrm{MBtu} / \mathrm{hr})$

- PLANT-EQUIPMENT(P-E) u-name or UTILITY

- NUMBER(N)(-;0.0 to $1,000.0) \dagger$

- COGEN-TRACK-MODE(TRACK-ELEC;TRACK-ELEC,TRACK-THERMAL, TRACK-LESSER,TRACK-GREATER,MAX-OUTPUT,DONT-RUN)

- COGEN-TRACK-SCH .u-namett

- DBUN-MIN-HEAT(0.0;0.0 to $\left.10^{6} \mathrm{MBtu}\right)$

- DIESEL-TRACK-MOD(TRACK-BOTH;TRACK-BOTH,TRACK-EXH,TRACK-JAC/LUB)

$\dagger$ If UTILITY is value of P-E keyword, NUMBER is the number of MBtu's from the utility and thus can exceed INSTALIED-NUMBER.

It Associated DAY-SCHEDULE takes the following values: $0=$ DONT-RUN, $1=$ TRACK-ELEC, $2=$ TRACK-THERMAL, $3=$ TRACK-LESSER, $4=$ TRACK-GREATER, $5=$ MAX-OUTPUT. 


\section{ENERGY-STORAGE(E-S,1)}

HEAT-STORE-RATE(H-ST-R)(0.0;0.0 to $1,000.0 \mathrm{MBtu} / \mathrm{hr})$

HEAT-SUPPLY-RATE(H-SU-R) $(0.0 ; 0.0$ to $1,000.0 \mathrm{MBtu} / \mathrm{hr})$

COOL-STORE-RATE(C-ST-R) $(0.0 ;-1,000$ to $1,000.0 \mathrm{MBtu} / \mathrm{hr}) \approx 2.1 \mathrm{E}$ will accept -999

COOL-SUPPLY-RATE(C-SU-R) $(0.0 ;-1,000$ to $1,000.0 \mathrm{MBtu} / \mathrm{hr})=2.1 \mathrm{E}$ will accept -999

HEAT-STORE-SCH(H-ST-SCH) U-name

COOL-STORE-SCH(C-ST-SCH) u-name

HTANK-LOSS-COEF(H-L-C) $\left(0.0 ; 0.0\right.$ to $\left.10^{5} \mathrm{Btu} / \mathrm{hr}-{ }^{\circ} \mathrm{F}\right)$

CTANK-LOSS-COEF(C-L-C) $\left(0.0 ; 0.0\right.$ to $\left.10^{5} \mathrm{Btu} / \mathrm{hr}-{ }^{\circ} \mathrm{F}\right)$

HTANK-BASE-T(H-B-T) $\left(100.0 ; 32.0\right.$ to $\left.212.0^{\circ} \mathrm{F}\right)$

CTANIL-BASE-T(C-B-T) $\left(80.0 ; 32.0\right.$ to $\left.212.0^{\circ} \mathrm{F}\right)$

HTANK-T-RANGE(H-T-R) $\left(10.0 ; 0.0\right.$ to $\left.180.0^{\circ} \mathrm{F}\right)$

CTANK-T-RANGE(C-T-R) $\left(10.0 ; 0.0\right.$ to $\left.180.0^{\circ} \mathrm{F}\right)$

HTANK-ENV-T(H-E-T)(ambient temperature;0.0 to $212.0^{\circ} \mathrm{F}$ )

CTANK-ENV-T(C-E-T) (ambient temperature;0.0 to $212.0^{\circ} \mathrm{F}$ )

HTANK-FREEZ-T(H-F-T)(32.0;-30.0 to 212.0 $\left.0^{\circ} \mathrm{F}\right)$

CTANK-FREEZ-T(C-F-T) $\left(32.0 ;-30.0\right.$ to $\left.212.0^{\circ} \mathrm{F}\right)$

- CTANK-ENV-T-SCH u-name of schedule

\section{LOAD-MANAGEMENT(L-M,1)}

HEAT-MULTIPLIER(H-M) $(0.0 ; 0.0$ to 10.0$)$

COOL-MULTIPLIER(C-M)(0.0;0.0 to 10.0)

ELEC-MULTIPLIER(E-M)(1.0;0.0 to 10.0)

- PRED-LOAD-RANGE(PRED-L-R)(-;0.0 to $1,000.0 \mathrm{MBtu} / \mathrm{hr})$

- ASSIGN-SCHEDULE(A-SCH) (list of u-names of schedules)(3 max.)

or

- LOAD-ASSIGNMENT(L-A) (list of u-names of L-As)(3 max.)

\section{PLANT-COSTS(P-C,1)}

DISCOUNT-RATE(D-R)(10.0;0.0 to $100.0 \% / \mathrm{yr})$

LABOR-INFLTN(L-I)(0.0;0.0 to $100.0 \% /$ yr)

MATERIALS-INFLTN(M-I)(0.0;0.0 to $100.0 \% / \mathrm{yr})$

PROJECT-LIFE(P-L) $(25.0 ; 1.0$ to $25.0 \mathrm{yr})$

SITE-FACTOR(S-F)(1.0;0.0 to 100.0)

LABOR(L)(25.0;0.0 to 100.0 dollar $/ \mathrm{hr})$

FIRST-COST-EXP(F-C-E)(0.67;0.0 to 2.0)

INSTALLATION-EXP(0.0;no limits)

CONSUMABLES-EXP(C-E)(0.4;0.0 to 2.0)

MAINTENANCE-EXP(M-E)(0.2;0.0 to 2.0)

LIFE-EXP(L-E)(0.1;0.0 to 2.0$)$

MIN-OVHL-INT-EXP(MIN-O-I)(0.2;0.0 to 2.0$)$

MIN-OVHL-CST-EXP(MIN-O-C) $(0.67 ; 0.0$ to 2.0$)$

MAJ-OVHI-INT-EXP(MAJ-O-I) $(0.2 ; 0.0$ to 2.0$)$

MAJ-OVHL-CST-EXP(MAJ-O-C)(0.67;0.0 to 2.0) 
ENERGY-RESOURCE(E-R,7)

- RESOURCE(R)(-;ELECTRICITY,DIESEL-OIL,NATURAL-GAS,

STEAM,CHILED-WATER,LPG,COAL,METHANOL,OTHER-FUEL)

SOURCE-SITE-EFF(S-S-E) $(\dagger ; 0.0$ to 1.0) [ + See the Supplement (2.1E) for default values.]

- FUEL-METERS (F-M) (M1;M1,M2,M3,M4,M5)

- ENERGY-UNTT(-;0.0 to 10,000,000 Btu/Unit)

- UNIT-NAME(-;up to 8 characters - alphnumeric)

- DEM-UNIT-NAME(-;up to 8 characters - alphanumeric)

- OTHER-FUEL-NAME(-;up to 16 characters - alphanumeric)

REFERENCE-COSTS(R-C,25)

- TYPE(-; $\dagger$ ) [ + Takes same code-words as TYPE in PLANT-EQUPPMENT command.]

SIZE-REF(S-R) (一;0.0 to $\left.10^{9} \mathrm{Btu} / \mathrm{hr}\right)$

FIRST-COST-REF(F-C-R) (-;0.0 to $10^{6}$ dollar)

INSTALLATION-REF(I-R) $(-; 0.0$ to 100.0$)$

CONSUMABLES-REF(C-R)(-;0.0 to $1,000.0$ dollar $/ \mathrm{hr})$

MAINTENANCE-REF(M-R) (-;0.0 to $1,000.0 \mathrm{hr} / \mathrm{yr})$

LIFE-REF(L-R) (-;0.0 to $\left.10^{6} \mathrm{hr}\right)$

MTN-OVHI-INT-REF(MTN-O-I) $\left(-; 0.0\right.$ to $\left.10^{5} \mathrm{hr}\right)$

MIN-OVHL_CST-REF(MIN-O-C)(-;0.0 to $10,000.0$ dollar)

MAJ-OVHL-INT-REF(MAJ-O-I) $\left(-; 0.0\right.$ to $\left.10^{5} \mathrm{hr}\right)$

MAJ-OVHL_CST-REF(MAJ-O-C)(-;0.0 to $10,000.0$ dollar)

PLANT-REPORT(P-R,1)

VERIFICATION(V)(PV-A;PV-A,PV-B,PV-C,PV-E,PV-F,PV-G,PV-H,

ALL-VERIFICATION)(list)

SUMMARY(S)(PS-A,PS-B,PS-D;PS-A,PS-B,PS-C,PS-D,PS-E,PS-F,

PS-G,PS-H,PS-I,BEPS,BEPU,ALL-SUMMARY)(list)

REPORT-FREQUENCY(R-F)(HOURLY;

HOURLY,DAIL,MONTHLY,YEARLY)

HOURLY-DATA-SAVE(H-D-S)(NO-SAVE;NO-SAVE,BINARY,FORMATTED)

[See page 116 for briel description; and Appendix C of the Supplement (2.1E) for a full description of all reports.]

$=$ REPORT-BLOCK $(\mathrm{R}-\mathrm{B}, 64)$

- VARIABLE-TYPE(V-T)(一;GLOBAL,PLANT,HEAT-RECOVERY END-USE,

LOADS-DATA,SYSTEMS-DATA or code-word of equipment type)

- VARIABLE-LIST(V-L)(-;code-numbers) $\dagger$

$\dagger \quad$ List of code-numbers; see Appendix $A$ in the Supplement (2.1E).

$=$ HOURLY-REPORT(H-R,16) See LOADS

END Required at end of Plant input

COMPUTE PLANT Required to do Plant simulation

STOP Use only if want BDL and simulation to stop here

- = Required keyword 


\section{ECONOMICS SUMMARY}

\section{INPUT ECONOMICS}

Required for Economics input

PARAMETRIC-INPUT ECONOMICS

Replaces INPUT ECONOMICS for parametric runs

TITLE

See LOADS

\section{ABORT}

(Only needed when overriding LOADS input)

DIAGNOSTIC(LIST)

(Only needed when overriding LOADS input)

\section{PARAMETER(DEFINE)}

See LOADS

$=$ DAY-SCHEDULE(D-SCH,300)

See LOADS

= WEEK-SCHEDULE(W-SCH,200)

See LOADS

$=$ SCHEDULE(SCH,100)

See LOADS

\section{$=$ BLOCK-CHARGE(B-C)(30)}

- BLOCI-SCH(B-SCH) (u-name)

- SCH-FLAG(FLAG)(1.0;key to hourly value used in a SCHEDULE)

- BLOCK1-TYPE(B1-T)(ENERGY;ENERGY,IKWH/KW,KWH/KW-LIMISUM,DEMAND)

BLOCIL1-DATA(B1-D)(0.0;list of up to 10 sets of block-size,cost/unit,limit)

BLOCK2-TYPE(B2-T)(ENERGY;ENERGY,KHW/KW,IKWH/KW-LIMITSUM,DEMAND)

- BLOCK2-DATA(B2-D)(0.0;list of up to 10 sets of block-size, cost/unit, limit)

BLOCK3-TYPE(B3-T)(ENERGY; ENERGY, KWH/KW, KWH/KW-LIMISSUM, DEMAND)

BLOCK3-DATA(B3-D)(0.0; list of up to 10 sets of block-size, cost/unit, limit)

DEMAND-RATCHETS(D-R)(accepts list of u-names of up to five RATCHETs)

TOU-SEASON-LINKS(TOU-LINK)(accepts list of u-names of BLOCK-GHARGEs) 


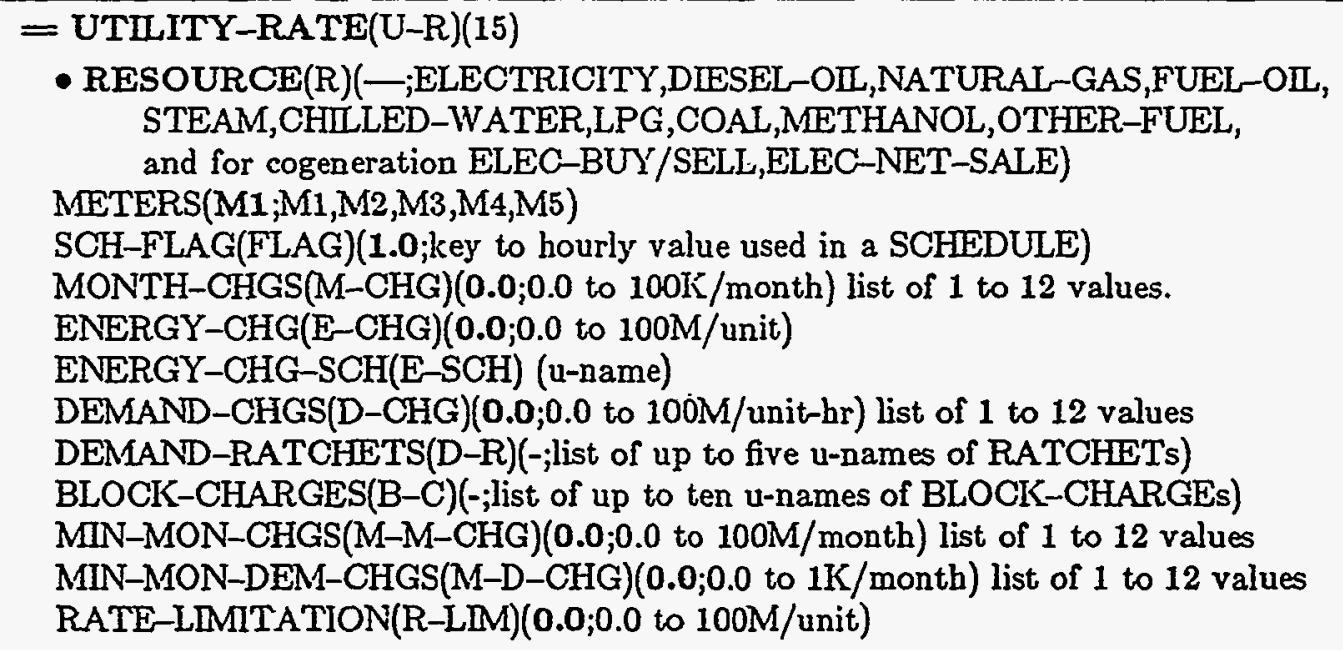

LIKE (-;accepts u-name of another UTIITY-RATE)

BILLING-DAYS(B-D)(31 or last day of month;list of 12 days, one for each month; 1 to 31)

ENERGY-QUALS(E-Q) $(0.0,0.0)$ (list of two monthly energy usages in $\mathrm{kWh}$ )

DEMAND-QUALS(D-Q)(0.0,0.0)(list of two monthly demands in $\mathrm{kW}$ )

USE-MIN-QUALS(U-M-Q)(NO; YES or NO)

QUALIFY-RATE(Q-R)(ALL-MONTHS;ALL-MONTHS,ONE-MONTH-MIN,

ALL-MONTHS-MIN,MONTH-BY-MONTH)

QUAL-SCH(Q-SCH) (u-name)

ENERGY-COST-ADJS(E-C-A)(0.0;-1M to 100M/unit) list of 1 to 12 values

DEMAND-WINDOW(D-WIN)(HOUR;HOUR,DAY)

POWER-FACTOR(P-F) $(0.8 ; 0.3$ to 1.0$)$

EXCESS-IIVAR-FRAC(E-K-F)(0.3;0.0 to 1.0)

EXCESS-IKVAR-CHG(E-IK-CHG)(0.0;0.0 to 100M/kVAR)

ESCALATION(ESC) $(5.0 \% ; 0.0$ to $100 \%)$

MIN-MON-RATCHETS(M-M-R)(-;u-name of up to 5 DEMAND-RATCHETs)

PCT-TAX-DATA(PCT-TX)(-;ist of up to 3 sets of charges)

PCT-TAXES-APPLY(TX-APLY)(BASE;BASE,ECA,SRCHGS)

UNIT-TAX-DATA(UNT-TX)(-;ist of up to 3 sets of charges)

PCT-SRCHG-DATA(PCT-SRG)(-;list of up to 3 sets of charges)

PCT-SRCHGS-APPLY(SRG-APLY)(BASE;BASE,ECA,TAXES)

UNT-SRCHG-DATA(UNT-CHG)(-;list of up to 3 sets of charges)

$=$ RATCHET(30)
NUM-MONTHS(N-M)(12;1 to 12)
RATCHET-SCH(R-SCH) (u-name)
SCH-FLAG(FLAG)(1.0; key to hourly value used in a SCHEDULE)
TYPE(HIGHEST-PEAK;HIGHEST-PEAK,AVERAGE)
OFFSET(0.0;-100,000,000 to 100,000,000 kW)
IRACTON(FRAC)(1.0;0.0 to 1.0)


$\Leftrightarrow$ COMPONENT-COST(C-C,15)

UNIT-NAME(U-N) [any alphanumeric name, $\leq 16$ characters] $\dagger$

NUMBER-OF-UNITS(N-O-U) $\left(1.0 ; 0.0\right.$ to $\left.10^{5}\right)$

FIRST-COST(F-C)(0.0;0.0 to $10^{7}$ dollar)

INSTALL-COST(I-C)(0.0;0.0 to $10^{6}$ dollar)

ANNUAL-COST(A-C)(0.0;0.0 to $10^{4}$ dollar)

COMPONENT-LIFE(C-L)(999.0;0.1 to $100.0 \mathrm{yrs})$

MIN-OVHI-INT(MIN-O-I)(899.0;0.1 to 50.0 yrs)

MIN-OVHL-COST(MIN-O-C)(0.0;0.0 to $10^{5}$ dollar)

MAJ-OVHI-INT(MAJ-O-I)(898.0;0.1 to 50.0 yrs)

MAJ_OVHL_COST(MAJ-O-C) $\left(0.0 ; 0.0\right.$ to $2 \times 10^{5}$ dollar)

+ Optional keyword; for user convenience only.

[Note: Costs are per unit; program calculates net cost by multiplying per-unit cost by NUMBER-OF-UNITS]

[Note: All costs should be in current dollars]

$(=)$ BASELINE(1)

FIRST-COST $(F-C)\left(0.0 ; 0.0\right.$ to $10^{6}$ dollar $)$

REPLACE-COST(R-C)(0.0;0.0 to $10^{6}$ dollar)

OPERATIONS-COST(O-C)(0.0;0.0 to $10^{5}$ dollar $) \dagger$

ENERGY-COST(E-C)(0.0;0.0 to $10^{6}$ dollar $) \dagger$

ENERGY-USE-SITE(E-U-SITE)(0.0;0.0 to $\left.10^{8} \mathrm{MBtu}\right)$

ENERGY-USE-SRC(E-U-SRC)(0.0;0.0 to $\left.10^{8} \mathrm{MBtu}\right)$

+ The value of these keywords is a list, up to 25 entries long, giving the present value of operations and energy costs for each year of the baseline project lifelime.

ECONOMICS-REPORT(E-R,1)

VERIFICATION(V)(-;EV-A,EV-B) (list)

SUMMARY(S)(ES-A;ES-A,ES-B,ES-C,ES-D,ES-E,ES-F,ALL-SUMMARY) (list)

[See page 116 lor briel description; and Appendix $\mathrm{C}$ of the

the Supplement ( $2.1 E$ ) for a full description of all reports.]

\section{END}

Required at end of Economics input

\section{COMPUTE ECONOMICS}

Required for Economics simulation

STOP

Use only if want BDL and simulation to stop here 


\section{Applicability of Commands and Keywords to System Types}

The following applicability tables for each HVAC system type have been updated for DOE-2.1E. Because there have been additions to the tables and many changes to the "Default Value or Consequence" column, we caution you NOT to use the same material found in the Reference Manual (2.1A).

The tables on the following pages indicate those commands and keywords in SYSTEMS that apply to the various system types. Keywords that are not used by a particular system type are not shown. The last column in each table shows one of two things:

1) for the SYSTEM-TYPE being described, either the default value that will be provided by the program if you choose not to enter the keyword, or

2) the consequence for the simulation of not entering the keyword.

Index of System Types

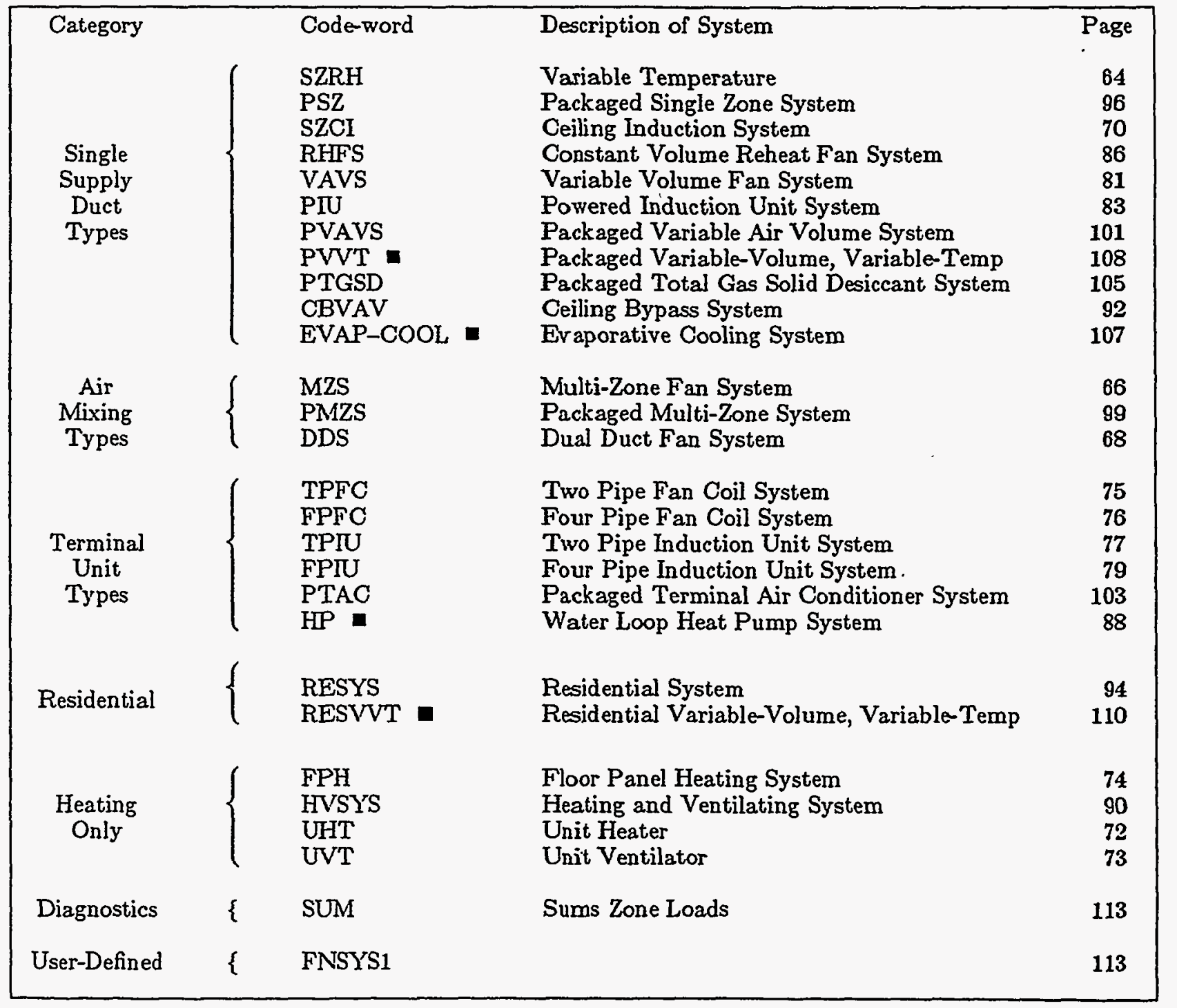


ZONE-level Commands and Keywords

For all System Types EXCEPT FPH, PIU, RESYS, PSZ, and SUM

(see individual Applicability Tables for these five systems)

\begin{tabular}{|c|c|c|}
\hline Command & Keyword & Default Value or Consequence \\
\hline ZONE-CONTROL & $\begin{array}{l}\text { DESIGN-HEAT-T } \\
\text { HEAT-TEMP-SCH } \\
\text { DESIGN-COOL-T } \\
\text { COOL-TEMP-SCH } \\
\text { THERMOSTAT-TYPE } \\
\text { THROTTLING-RANGE } \\
\text { BASEBOARD-CTRL } \\
\end{array}$ & $\begin{array}{l}70^{\circ} \mathrm{F} \\
\text { No active heating control } \\
76^{\circ} \mathrm{F} \\
\text { No active cooling control } \\
\text { (Not used for UHT and HVSY) } \\
\text { PROPORTIONAL } \\
2^{\circ} \mathrm{F} \\
\text { OUTDOOR-RESET }\end{array}$ \\
\hline \multirow[t]{3}{*}{ ZONE-AIR } & $\begin{array}{l}\text { ASSIGNED-CFM } \\
\text { CFM/SQFT } \\
\text { AIR-CHANGES/HR }\end{array}$ & $\begin{array}{l}\text { Based on heating/cooling } \\
\text { loads, supply air, } \Delta T \text {, and } \\
\text { sizing ratio }\end{array}$ \\
\hline & $\begin{array}{l}\text { OUTSIDE-AIR-CFM } \\
\text { OA-CFM/PER } \\
\text { OA-CHANGES }\end{array}$ & $\left\{\begin{array}{l}\text { Based on } \\
\text { MIN-OUTSIDE-AIR } \\
\text { (Not used for UHT) }\end{array}\right.$ \\
\hline & $\begin{array}{l}\text { EXHAUST-CFM } \\
\text { EXHAUST-EFF } \\
\text { EXHAUST-STATIC } \\
\text { EXHAUST-ISW } \\
\\
\text { SS-VENT-SCH } \\
\text { SS-VENT-T-SCH } \\
\text { SS-VENT-CST } \\
\text { SS-VENT-WND } \\
\text { SS-VENT-TEMP } \\
\text { SS-VENT-LIMIT-T } \\
\text { SS-VENT-KW } \\
\text { SS-FLOW-SCH } \\
\text { SS-FLOW-T-SCH } \\
\end{array}$ & $\begin{array}{l}0.0 \text { (Not used for UHT, UVT, HP, and PTAC) } \\
0.75 \text { (Not used for UHT, UVT, HP, and PTAC) } \\
0.0 \text { (Not used for UHT, UVT, HP, and PTAC) } \\
\text { From EXHAUST-EFF and EXHAUST-STATIC } \\
\text { (Not used for UHT, UVT, HP, and PTAC) } \\
\text { No venting of sunspace } \\
\text { No venting of sunspace } \\
5.0 \text { ach } \\
0.01 / k \text { knt } \\
0.01 / /^{\circ} \mathrm{F} \text {. } \\
120.0^{\circ} \mathrm{F} \\
0.0 \\
\text { No effect on air flow } \\
74^{\circ} \mathrm{F} \\
\end{array}$ \\
\hline \multirow[t]{3}{*}{ ZONE } & $\begin{array}{l}\text { ZONE-CONTROL } \\
\text { ZONE-AIR } \\
\text { ZONE-TYPE } \\
\text { MULTIPLIER } \\
\text { FLOOR-MULTIPLIER } \\
\text { MAX-HEAT-RATE } \\
\text { MAX-COOI-RATE } \\
\text { BASEBOARD-RATING }\end{array}$ & $\begin{array}{l}\S \\
\S \\
\text { CONDITIONED } \\
\text { Taken from SPACE in LOADS } \\
\text { Taken from SPACE in LOADS } \\
\text { Peak load or } 1.08 \times \triangle T \times C F M \\
\text { Peak load or } 1.08 \times \triangle \mathrm{T} \times \mathrm{CFM} \\
\text { (Not used for UHT and UVT) } \\
\text { No baseboard heating }\end{array}$ \\
\hline & $\begin{array}{l}\text { HEATING-CAPACITY } \\
\text { COOLING-CAPACITY } \\
\text { COOL-SH-CAP }\end{array}$ & $\begin{array}{l}\text { From SYSTEM-EQUTPMENT (Used } \\
\text { only for UHT, UVT, TPFC, FPFC, } \\
\text { TPIU, FPIU, HP, and PTAC) } \\
\text { (UHT and UVT do not use } \\
\text { COOLING-CAPACITY and } \\
\text { COOI-SH-CAP) }\end{array}$ \\
\hline & $\begin{array}{l}\text { MIN-CFM-RATIO } \\
\text { MIN-CFM-SCH } \\
\text { SIZING-OPTION } \\
\text { TROM-VENT-SCH } \\
\end{array}$ & $\begin{array}{l}\text { From SYSTEM-TERMINAL } \dagger \\
\text { MIN-CFM-RATIO } \$ \\
\text { FROM-LOADS } \\
\text { (only if TROMBE-WALI-V specified) }\end{array}$ \\
\hline \multicolumn{3}{|c|}{ Note: meter keywords default to System Values } \\
\hline $\begin{array}{l}\S \text { Any keyword fror } \\
t \quad \text { Used only for SZ } \\
\end{array}$ & $\begin{array}{l}\text { may be placed in } t \\
\text { S, RHFS, CBVAV }\end{array}$ & $\begin{array}{l}\text { amand. } \\
\text { PVAVS }\end{array}$ \\
\hline
\end{tabular}




\section{SZRH-System Type:}

Single Zone Fan System with Optional Sub-Zone Reheat

\begin{tabular}{|c|c|c|}
\hline Command & Keyword & Default Value or Consequence \\
\hline $\begin{array}{l}\text { ZONE-level } \\
\text { commands }\end{array}$ & See pages 63,88 & \\
\hline SYSTEM-CONTROL & $\begin{array}{l}\text { MAX-SUPPLY-T } \\
\text { MIN-SUPPLY-T } \\
\text { HEATING-SCHEDULE } \\
\text { COOLING-SCHEDULE } \\
\text { PREHEAT-T } \\
\text { MAX-HUMIDITY } \\
\text { MIN-HUMIDITY } \\
\text { ECONO-LIMIT-T } \\
\text { ECONO-LOW-LIMIT } \\
\text { BASEBOARD-SCH }\end{array}$ & $\begin{array}{l}105^{\circ} \mathrm{F} \\
55^{\circ} \mathrm{F} \\
\text { Always available } \\
\text { Always available } \\
45^{\circ} \mathrm{F} \\
\text { No dehumidification control } \\
\text { No humidification } \\
\text { Return air temperature } \square \text { changed in } 2.1 \mathrm{E} \\
\text { No lower limit } \\
\text { Always off }\end{array}$ \\
\hline SYSTEM-AIR & $\begin{array}{l}\text { SUPPLY-CFM } \\
\text { RETURN-CFM } \\
\text { MIN-OUTSIDE-AIR } \\
\text { MIN-AIR-SCH } \\
\text { OA-CONTROL } \\
\text { MAX-OA-FRACTION } \\
\text { RECOVERY-EFF } \\
\text { DUCT-AIR-LOSS } \\
\text { DUCT-DELTA-T } \\
\end{array}$ & $\begin{array}{l}\text { From ZONE-AIR or load } / 1.08 \times \triangle T \\
\text { SUPPLY-CFM minus EXHAUST-CFM or } 0 \\
\text { From ZONE-AIR or none } \\
\text { No scheduling of outside air } \\
\text { TEMP } \\
1.0 \\
\text { No heat recovery simulated } \\
\text { None } \\
\text { None }\end{array}$ \\
\hline \multirow[t]{2}{*}{ SYSTEM-FANS } & $\begin{array}{l}\text { SUPPLY-STATIC } \\
\text { SUPPLY-EFF } \\
\text { SUPPLY-DELTA-T } \\
\text { SUPPLY-IN } \\
\text { FAN-SCHEDULE } \\
\text { FAN-CONTROL } \\
\text { SUPPLY-MECH-EFF } \\
\text { MOTOR-PLACEMENT } \\
\text { FAN-PLACEMENT } \\
\text { MAX-FAN-RATIO } \\
\text { MIN-FAN-RATIO } \\
\text { RETURN-STATIC } \\
\text { RETURN-EFF } \\
\text { RETURN-DELTA-T } \\
\text { RETURN-IKW } \\
\text { NIGHT-OYCLE-CTRL } \\
\text { FAN-EIR-FPLR }\end{array}$ & $\begin{array}{l}\text { From SUPPLY-DELTA-T \& SUPPLY-KW } \\
\text { From SUPPLY-DELTA-T \& SUPPLY-KW } \\
2.42^{\circ} \mathrm{F} \\
0.000783 \mathrm{~kW} / \mathrm{cfm} \\
\text { Always on } \\
\text { CONSTANT-VOLUME } \\
\text { From SUPPLY-EFF } \\
\text { IN-AIRFLOW } \\
\text { DRAW-THROUGH } \\
1.1 \\
\text { O.3 } \\
\text { No return fan is simulated if neither pair } \\
\text { (RETURN-STATIC, RETURN-EFF) } \\
\text { or (RETURN-DELTA-T, RETURN-KW) } \\
\text { is Specified. } \\
\text { STAY-OFF } \\
\text { (only if FAN-CONTROL=FAN-EIR-FPLR) }\end{array}$ \\
\hline & & Continued on next page. \\
\hline
\end{tabular}




\begin{tabular}{|c|c|c|}
\hline \multicolumn{3}{|c|}{$\begin{array}{l}\text { Continuation of } \\
\text { SZRH-System Type: } \\
\text { Ie Fan System with Optional Sub-Zone Reheat }\end{array}$} \\
\hline Command & Keyword & Default Value or Consequence \\
\hline SYSTEM-TERMINAL & $\begin{array}{l}\text { REHEAT-DELTA-T } \\
\text { MIN-CFM-RATIO }\end{array}$ & $\begin{array}{l}\text { No reheat simulated in subzones } \\
\text { Constant volume system }\end{array}$ \\
\hline SYSTEM-EQUTPMENT & See page 36 & \\
\hline SYSTEM & $\begin{array}{l}\text { SYSTEM-TYPE=SZRH } \\
\text { ZONE-NAMES } \\
\text { SYSTEM-CONTROL } \\
\text { SYSTEM-AIR } \\
\text { SYSTEM-FANS } \\
\text { SYSTEM-TERMINAL } \\
\text { SYSTEM-EQUIPMENT } \\
\text { HEAT-SOURCE } \\
\text { ZONE-HEAT-SOURCE } \\
\text { PREHEAT-SOURCE } \\
\text { BASEBOARD-SOURCE } \\
\text { HUMIDIFIER-TYPE } \\
\text { SIZING-RATIO } \\
\text { SIZING-OPTION } \\
\text { RETURN-AIR-PATH } \\
\text { PLENUM-NAMES } \\
\end{array}$ & $\begin{array}{l}\text { - (First listed must be control zone) } \\
\S \\
\S \\
\S \\
\S \\
\S \\
\text { HOT-WATER } \\
\text { HOT-WATER } \\
\text { HOT-WATER } \\
\text { HOT-WATER } \\
\text { HOT-WATER } \\
\text { 1.0 } \\
\text { NON-COINCIDENT } \\
\text { DIRECT } \\
\text { No return air plenum }\end{array}$ \\
\hline PLANT-ASSIGNMENT & See page 43 & \\
\hline
\end{tabular}

In addition to the keywords listed above, all keywords that apply to

Night Ventilation (SYSTEM-FANS command)

Add-On Evaporative Cooling (SYSTEM-EQUIPMENT command)

Add-On (Integrated) Desiccant Cooling (SYSTEM command)

Service Hot Water Heat Pump (SYSTEM and PLANT-ASSIGNMENT commands)

Electric and Fuel Meters (SYSTEM, ZONE, and PLANT-ASSIGNMENT commands)

Building Resources (PLANT-ASSIGNMENT commands)

apply to this system. 


\begin{tabular}{|c|c|c|}
\hline \multicolumn{3}{|c|}{ MZS-System Type: Multi-Zone Fan System } \\
\hline Command & Keyword & Default Value or Consequence \\
\hline $\begin{array}{l}\text { ZONE-level } \\
\text { commands }\end{array}$ & See pages 63,88 & \\
\hline SYSTEM-CONTROL & $\begin{array}{l}\text { MAX-SUPPLY-T } \\
\text { MIN-SUPPLY-T } \\
\text { HEATING-SCHEDULE } \\
\text { COOLING-SCHEDULE } \\
\text { HEAT-CONTROL } \\
\text { HEAT-SET-T } \\
\text { HEAT-RESET-SCH } \\
\text { HEAT-SET-SCH } \\
\text { COOL-CONTROL } \\
\text { COOL-SET-T } \\
\text { COOI-RESET-SCH } \\
\text { COOL-SET-SCH } \\
\text { PREHEAT-T } \\
\text { MAX-HUMIDITY } \\
\text { MIN-HUMIDITY } \\
\text { ECONO-LIMIT-T } \\
\text { ECONO-LOW-LIMIT } \\
\text { BASEBOARD-SCH }\end{array}$ & $\begin{array}{l}105^{\circ} \mathrm{F} \\
55^{\circ} \mathrm{F} \\
\text { Always available } \\
\text { Always available } \\
\text { CONSTANT } \\
\text { From MAX-SUPPLY-T } \\
\text { (only if HEAT-CONTROL=RESET) } \\
\circ \text { (only if HEAT-CONTROL=SCHEDULED) } \\
\text { CONSTANT } \\
\text { MIN-SUPPLY-T } \\
\text { (only if COOL-CONTROL=RESET) } \\
\text { (only if COOL-CONTROL=SCHEDULED) } \\
45^{\circ} \mathrm{F} \\
\text { No dehumidification control } \\
\text { No humidification } \\
\text { Return air temperature changed in } 2.1 \mathrm{C} \\
\text { No lower limit } \\
\text { Always of }\end{array}$ \\
\hline SYSTEM-AIR & $\begin{array}{l}\text { SUPPLY-CFM } \\
\text { RETURN-CFM } \\
\text { MIN-OUTSIDE-AIR } \\
\text { MIN-AIR-SCH } \\
\text { OA-CONTROL } \\
\text { MAX-OA-FRACTION } \\
\text { RECOVERY-EFF } \\
\text { DUCT-AIR-LOSS } \\
\text { DUCT-DELTA-T } \\
\text { SUPPLY-STATIC } \\
\text { SUPPLY-EFF } \\
\text { SUPPLY-DELTA-T } \\
\text { SUPPLYKW } \\
\text { FAN-SCHEDULE } \\
\text { FAN-CONTROL } \\
\text { SUPPLY-MECH-EFF } \\
\text { MOTOR-PLACEMENT } \\
\text { MAX-FAN-RATIO } \\
\text { MIN-FAN-RATIO } \\
\text { RETURN-STATIC } \\
\text { RETURN-EFF } \\
\text { RETURN-DELTA-T } \\
\text { RETURN-KW } \\
\text { NIGHT-CYCLE-CTRL } \\
\text { FAN-EIR-FPLR } \\
\end{array}$ & $\begin{array}{l}\text { From ZONE-AIR or load/1.08X } \triangle T \\
\text { SUPPLY-CFM minus EXHAUST-CFM or } 0 \\
\text { From ZONE-AIR or none } \\
\text { No scheduling of outside air } \\
\text { TEMP } \\
1.0 \\
\text { No heat recovery simulated } \\
\text { None } \\
\text { None } \\
\text { From SUPPLY-DELTA-T \& SUPPLY-KW } \\
\text { From SUPPLY-DELTA-T \& SUPPLY-KW } \\
2.723^{\circ} \mathrm{F} \\
\text { 0.00088 kW/cfm } \\
\text { Always on } \\
\text { CONSTANT-VOLUME } \\
\text { From SUPPLY-EFF } \\
\text { IN-AIRFLOW } \\
1.1 \\
\text { 0.3 } \\
\text { 1No return fan is simulated if neither pair } \\
\text { (RETURN-STATIC, RETURN-EFF) } \\
\text { or (RETURN-DELTA-T, RETURN-KW) } \\
\text { is specified. } \\
\text { STAY-OFF } \\
\text { (only if FAN-CONTROL=FAN-EIR-FPLR) }\end{array}$ \\
\hline & & Continued on next page. \\
\hline
\end{tabular}




\begin{tabular}{|c|c|c|}
\hline \multicolumn{3}{|c|}{$\begin{array}{c}\text { Continuation of } \\
\text { MZS-System Type: Multi-Zone Fan System }\end{array}$} \\
\hline Command & Keyword & Default Value or Consequence \\
\hline SYSTEM-TERMINAL & MIN-CFM-RATIO & Constant volume system \\
\hline SYSTEM-EQUIPMENT & See page 36 & \\
\hline SYSTEM & $\begin{array}{l}\text { SYSTEM-TYPE=MZS } \\
\text { ZONE-NAMES } \\
\text { SYSTEM-CONTROI } \\
\text { SYSTEM-AIR } \\
\text { SYSTEM-FANS } \\
\text { SYSTEM-TERMINAL } \\
\text { SYSTEM-EQUIPMENT } \\
\text { HEAT-SOURCE } \\
\text { PREHEAT-SOURCE } \\
\text { BASEBOARD-SOURCE } \\
\text { HUMIDIFIER-TTYE } \\
\text { SIZING-RATIO } \\
\text { SIZING-OPTION } \\
\text { RETURN-AIR-PATH } \\
\text { PLENUM-NAMES } \\
\end{array}$ & $\begin{array}{l}: \\
: \\
5 \\
5 \\
5 \\
\$ \\
\mathbf{5} \\
\text { HOT-WATER } \\
\text { HOT-WATER } \\
\text { HOT-WATER } \\
\text { HOT-WATER } \\
1.0 \\
\text { NON-COINCDENT } \\
\text { DIRECT } \\
\text { No return air plenum }\end{array}$ \\
\hline PLANT-ASSIGNMENT & See page 43 & - \\
\hline
\end{tabular}

In addition to the keywords listed above, all keywords that apply to

Night Ventilation (SYSTEM-FANS command)

Add-On Evaporative Cooling (SYSTEM-EQUIPMENT command)

Add-On (Integrated) Desiccant Cooling (SYSTEM command)

Service Hot Water Heat Pump (SYSTEM and PLANT-ASSIGNMENT commands)

Electric and Fuel Meters (SYSTEM, ZONE, and PLANT-ASSIGNMENT commands)

Building Resources (PLANT-ASSIGNMENT commands)

apply to this system.

$\bullet=$ Required keyword 


\begin{tabular}{|c|c|c|}
\hline \multicolumn{3}{|c|}{ DDS-System Type: Dual Duct Fan System } \\
\hline Command & Keyword & Default Value or Consequence \\
\hline $\begin{array}{l}\text { ZONE-level } \\
\text { commands }\end{array}$ & See pages 63,88 & \\
\hline SYSTEM-CONTROL & $\begin{array}{l}\text { MAX-SUPPLY-T } \\
\text { MIN-SUPPLY-T } \\
\text { HEATING-SCHEDULE } \\
\text { COOLING-SCHEDULE } \\
\text { HEAT-CONTROL } \\
\text { HEAT-SET-T } \\
\text { HEAT-RESET-SCH } \\
\text { HEAT-SET-SCH } \\
\text { COOL-CONTROL } \\
\text { COOL-SET-T } \\
\text { COOL-RESET-SCH } \\
\text { COOL-SET-SCH } \\
\text { PREHEAT-T } \\
\text { MAX-HUMIDITY } \\
\text { MIN-HUMIDITY } \\
\text { ECONO-LIMIT-T } \\
\text { ECONO-LOW-LMIT } \\
\text { BASEBOARD-SCH }\end{array}$ & $\begin{array}{l}105^{\circ} \mathrm{F} \\
55^{\circ} \mathrm{F} \\
\text { Always available } \\
\text { Always available } \\
\text { CONSTANT } \\
\text { From MAX-SUPPLY-T } \\
\text {-(only if HEAT-CONTROL=RESET) } \\
\text {-(only if HEAT-CONTROL=SCHEDULED) } \\
\text { CONSTANT } \\
\text { MNN-SUPPLY-T } \\
\text { (only if COOL-CONTROL=RESET) } \\
\text { (only if COOL-CONTROL=SCHEDULED) } \\
45^{\circ} \mathrm{F} \\
\text { No dehumidification control } \\
\text { No humidification } \\
\text { Return air temperature changed in } 2.1 \mathrm{a} \\
\text { No lower limit } \\
\text { Always off }\end{array}$ \\
\hline SYSTEM-AIR & $\begin{array}{l}\text { SUPPLY-CFM } \\
\text { RETURN-CFM } \\
\text { MIN-OUTSIDE-AIR } \\
\text { MIN-AIR-SCH } \\
\text { OA-CONTROL } \\
\text { MAX-OA-FRACTION } \\
\text { RECOVERY-EFF } \\
\text { DUCT-AIR-LOSS } \\
\text { DUCT-DELTA-T } \\
\end{array}$ & $\begin{array}{l}\text { From ZONE-AIR or load } / 1.08 \times \triangle T \\
\text { SUPPLY-CFM minus EXHAUST-CFM or } 0 \\
\text { From ZONE-AIR or none } \\
\text { No scheduling of outside air } \\
\text { TEMP } \\
1.0 \\
\text { No heat recovery simulated } \\
\text { None } \\
\text { None }\end{array}$ \\
\hline SYSTEM-FANS & $\begin{array}{l}\text { SUPPLY-STATIC } \\
\text { SUPPLY-EFF } \\
\text { SUPPLY-DELTA-T } \\
\text { SUPPLY-KW } \\
\text { FAN-SCHEDULE } \\
\text { FAN-CONTROL } \\
\text { SUPPLY-MECH-EFF } \\
\text { MOTOR-PLACEMENT } \\
\text { MAX-FAN-RATIO } \\
\text { MIN-FAN-RATIO } \\
\text { RETURN-STATIC } \\
\text { RETURN-EFF } \\
\text { RETURN-DELTA-T } \\
\text { RETURN-KW } \\
\text { NIGHT-CYCLE-CTRL } \\
\text { FAN-EIR-FPLR } \\
\end{array}$ & $\begin{array}{l}\text { From SUPPLY-DELTA-T \& SUPPLY-KW } \\
\text { From SUPPLY-DELTA-T \& SUPPLY-KW } \\
3.37^{\circ} \mathrm{F} \\
0.00109 \mathrm{~kW} / \mathrm{cim} \\
\text { Always on } \\
\text { CONSTANT-VOLUME } \\
\text { From SUPPLY-EFF } \\
\text { IN-AIRFLOW } \\
1.1 \\
0.3 \\
\text { If neither pair, (RETURN-STATIC, } \\
\text { RETURN-EFF) or (RETURN-DELTA-T, } \\
\text { RETURN-KW), is specified, } \\
\text { Ro return fan is simulated. } \\
\text { STAY-OFF } \\
\text { (only if FAN-CONTROL=FAN-EIR-FPLR) }\end{array}$ \\
\hline & & Continued on next page. \\
\hline
\end{tabular}


SYSTEM TYPES

\begin{tabular}{|c|c|c|}
\hline \multicolumn{3}{|c|}{$\begin{array}{c}\text { Continuation of } \\
\text { DDS-System Type: Dual Duct Fan System }\end{array}$} \\
\hline Command & Keyword & Default Value or Consequence \\
\hline SYSTEM-TERMINAL & MIN-CFM-RATIO & $\begin{array}{l}\text { Constant volume system } \\
\text { (therefore is required } \\
\text { for DDVAV simulation) }\end{array}$ \\
\hline SYSTEM-EQUIPMENT & See page 36 & \\
\hline SYSTEM & $\begin{array}{l}\text { SYSTEM-TYPE=DDS } \\
\text { ZONE-NAMES } \\
\text { SYSTEM-CONTROL } \\
\text { SYSTEM-AIR } \\
\text { SYSTEM-FANS } \\
\text { SYSTEM-TERMINAL } \\
\text { SYSTEM-EQUIPMENT } \\
\text { HEAT-SOURCE } \\
\text { PREHEAT-SOURCE } \\
\text { BASEBOARD-SOURCE } \\
\text { HUMIDIFIER-TYPE } \\
\text { SIZING-RATIO } \\
\text { SIZING-OPTION } \\
\text { RETURN-AIR-PATH } \\
\text { PLENUM-NAMES }\end{array}$ & $\begin{array}{l}\bullet \\
\vdots \\
\S \\
\S \\
\S \\
\S \\
\text { HOT-WATER } \\
\text { HOT-WATER } \\
\text { HOT-WATER } \\
\text { HOT-WATER } \\
\text { 1.0 } \\
\text { NON-COINCIDENT } \\
\text { DUCT } \\
\text { No return air plenum }\end{array}$ \\
\hline PLANT-ASSIGNMENT & See page 43 & \\
\hline
\end{tabular}

In addition to the keywords listed above, all keywords that apply to

Night Ventilation (SYSTEM-FANS command)

Add-On Evaporative Cooling (SYSTEM-EQUIPMENT command)

Add-On (Integrated) Desiccant Cooling (SYSTEM command)

Service Hot Water Heat Pump (SYSTEM and PLANT-ASSIGNMENT commands)

apply to this system.

$\bullet=$ Required keyword

$-69-$

- = Added/changed in 2.1E 


\begin{tabular}{|c|c|c|}
\hline \multicolumn{3}{|c|}{ SZCI-System Type: Ceiling Induction System } \\
\hline Command & Keyword & Default Value or Consequence \\
\hline $\begin{array}{l}\text { ZONE-level } \\
\text { commands }\end{array}$ & \multicolumn{2}{|l|}{ See pages 63,88} \\
\hline SYSTEM-CONTROL & $\begin{array}{l}\text { MAX-SUPPLY-T } \\
\text { MIN-SUPPLY-T } \\
\text { HEATING-SCHEDULE } \\
\text { COOLING-SCHEDUIE } \\
\text { HEAT-SET-T } \\
\text { COOL-CONTROL } \\
\text { COOL-SET-T } \\
\text { COOL-RESET-SCH } \\
\text { COOL-SET-SCH } \\
\text { PREHEAT-T } \\
\text { MAX-HUMIDITY } \\
\text { MIN-HUMIDITY } \\
\text { ECONO-LIMIT-T } \\
\text { ECONO-LOW-LIMIT } \\
\text { BASEBOARD-SCH }\end{array}$ & $\begin{array}{l}105^{\circ} \mathrm{F} \\
55^{\circ} \mathrm{F} \\
\text { Always available } \\
\text { Always available } \\
\text { From MAX-SUPPLY-T (for design only) } \\
\text { CONSTANT } \\
\text { MIN-SUPPLY-T } \\
\text { (only if COOL-CONTROL=RESET) } \\
\text { (only if COOL-CONTROL=SCHEDULED) } \\
45^{\circ} \mathrm{F} \\
\text { No dehumidification control } \\
\text { No humidification } \\
\text { Return air temperature } \text { changed in } 2.1 \mathrm{E}^{\text {No lower limit }} \\
\text { Always off }\end{array}$ \\
\hline SYSTEM-AIR & $\begin{array}{l}\text { SUPPLY-CFM } \\
\text { RETURN-CFM } \\
\text { MIN-OUTSIDE-AIR } \\
\text { MIN-AIR-SCH } \\
\text { OA-CONTROL } \\
\text { MAX-OA-FRACTION } \\
\text { RECOVERY-EFF } \\
\text { DUCT-AIR-LOSS } \\
\text { DUCT-DELTA-T }\end{array}$ & $\begin{array}{l}\text { From ZONE-AIR or load/1.08X } \triangle \mathrm{T} \\
\text { SUPPLY-CFM minus EXHAUST-CFM or } 0 \\
\text { From ZONE-AIR or none } \\
\text { No scheduling of outside air } \\
\text { TEMP } \\
1.0 \\
\text { No heat recovery simulated } \\
\text { None } \\
\text { None }\end{array}$ \\
\hline \multirow[t]{2}{*}{ SYSTEM-FANS } & $\begin{array}{l}\text { SUPPLY-STATIC } \\
\text { SUPPLY-EFF } \\
\text { SUPPLY-DELTA-T } \\
\text { SUPPLY-KW } \\
\text { FAN-SCHEDULE } \\
\text { FAN-CONTROL } \\
\text { SUPPLY-MECH-EFF } \\
\text { MOTOR-PLACEMENT } \\
\text { FAN-PLACEMENT } \\
\text { MAX-FAN-RATIO } \\
\text { MMN-FAN-RATIO } \\
\text { RETURN-STATIC } \\
\text { RETURN-EFF } \\
\text { RETURN-DELTA-T } \\
\text { RETURN-IKW } \\
\text { NIGHT-CYCLE-CTRL } \\
\text { FAN-EIR-FPLR }\end{array}$ & $\begin{array}{l}\text { From SUPPLY-DELTA-T \& SUPPLY-KW } \\
\text { From SUPPLY-DELTA-T \& SUPPLY-KW } \\
3.11^{\circ} \mathrm{F} \\
0.00101 \mathrm{~kW} / \mathrm{cfm} \\
\text { Always on } \\
\text { INLET } \\
\text { From SUPPLY-EFF } \\
\text { IN-AIRFLOW } \\
\text { DRAW-THROUGH } \\
1.1 \\
0.3 \\
\text { No return fan is simulated if neither pair } \\
\text { (RETURN-STATIC, RETURN-EFF) } \\
\text { or (RETURN-DELTA-T, RETURN-KW) } \\
\text { is specified. } \\
\text { STAY-OFF } \\
\text { (only if FAN-CONTROL=FAN-EIR-FPLR) }\end{array}$ \\
\hline & & Continued on next page. \\
\hline
\end{tabular}


SYSTEM TYPES

\begin{tabular}{|c|c|c|}
\hline \multicolumn{3}{|c|}{$\begin{array}{c}\text { Continuation of } \\
\text { SZCI-System Type: Ceiling Induction System }\end{array}$} \\
\hline Command & Keyword & Default Value or Consequence \\
\hline SYSTEM-TERMINAL & REHEAT-DELTA-T & No reheat simulated \\
\hline SYSTEM-EQUIPMENT & See page 114-115 & \\
\hline SYSTEM & $\begin{array}{l}\text { SYSTEM-TYPE=SZCI } \\
\text { ZONE-NAMES } \\
\text { SYSTEM-CONTROI } \\
\text { SYSTEM-AIR } \\
\text { SYSTEM-FANS } \\
\text { SYSTEM-TERMINAL } \\
\text { SYSTEM-EQUIPMENT } \\
\text { HEAT-SOURCE } \\
\text { ZONE-HEAT-SOURCE } \\
\text { PREHEAT-SOURCE } \\
\text { BASEBOARD-SOURCE } \\
\text { HUMIDIFIER-TYPE } \\
\text { SIZING-RATIO } \\
\text { SIZING-OPTION } \\
\text { RETURN-AIR-PATH } \\
\text { PLENUM-NAMES }\end{array}$ & $\begin{array}{l}\bullet \\
\vdots \\
\S \\
\S \\
\S \\
\S \\
\text { HOT-WATER } \\
\text { HOT-WATER } \\
\text { HOT-WATER } \\
\text { HOT-WATER } \\
\text { HOT-WATER } \\
\text { 1.0 } \\
\text { NON-COINCIDENT } \\
\text { DUCT } \\
\text { No return air plenum }\end{array}$ \\
\hline PLANT-ASSIGNMENT & See page 43 & \\
\hline
\end{tabular}

In addition to the keywords listed above, all keywords that apply to

Night Ventilation (SYSTEM-FANS command)

Add-On Evaporative Cooling (SYSTEM-EQUIPMENT command)

Add-On (Integrated) Desiccant Cooling (SYSTEM command)

Service Hot Water Heat Pump (SYSTEM and PLANT-ASSIGNMENT commands)

Electric and Fuel Meters (SYSTEM, ZONE, and PLANT-ASSIGNMENT commands)

Building Resources (PLANT-ASSIGNMENT commands)

apply to this system.

$\bullet=$ Required keyword $\quad-71-\quad \quad=$ Added/changed in 2.1E 


\begin{tabular}{|c|c|c|}
\hline \multicolumn{3}{|c|}{ UHT-System Type: Unit Heater } \\
\hline Command & Keyword & Default Value or Consequence \\
\hline $\begin{array}{l}\text { ZONE-level } \\
\text { commands }\end{array}$ & See pages 63,88 & \\
\hline SYSTEM-CONTROL & $\begin{array}{l}\text { MAX-SUPPLY-T } \\
\text { HEATING-SCHEDULE } \\
\text { BASEBOARD-SCH }\end{array}$ & $\begin{array}{l}105^{\circ} \mathrm{F} \\
\text { Always available } \\
\text { Always off } \\
\end{array}$ \\
\hline SYSTEM-FANS & $\begin{array}{l}\text { SUPPLY-STATIC } \\
\text { SUPPLY-EFF } \\
\text { SUPPLY-DELTA-T } \\
\text { SUPPLY-KW } \\
\text { FAN-SCHEDULE } \\
\text { NIGHT-CYOLE-GTRL }\end{array}$ & $\begin{array}{l}\text { From SUPPLY-DELTA-T \& SUPPLY-KW } \\
\text { From SUPPLY-DELTA-T \& SUPPLY-KW } \\
0.218^{\circ} \mathrm{F} \\
0.00007 \mathrm{~kW} / \mathrm{cm} \\
\text { Always on } \\
\text { STAY-OFF } \\
\end{array}$ \\
\hline SYSTEM-EQUIPMENT & $\begin{array}{l}\text { HEATING-CAPACITY } \\
\text { FURNACE-AUX } \\
\text { FURNACE-HIR } \\
\text { FURNACE-AUX-KW } \\
\text { FURNACE-HIR-FPLR } \\
\text { FURNACE-OFF-LOSS }\end{array}$ & $\begin{array}{l}\text { Dependent on peak loads } \\
800.0 \mathrm{Btu} / \mathrm{hr} \\
1.35 \mathrm{Btu} / \mathrm{Btu} \\
0.0 \mathrm{~kW} \\
\text { Standard curve SDI-C111 } \\
\text { No loss accounted for } \\
\end{array}$ \\
\hline SYSTEM & $\begin{array}{l}\text { SYSTEM-TYPE=UHT } \\
\text { ZONE-NAMES } \\
\text { SYSTEM-CONTROL } \\
\text { SYSTEM-FANS } \\
\text { SYSTEM-EQUIPMENT } \\
\text { HEAT-SOURCE } \\
\text { BASEBOARD-SOURCE } \\
\text { SIZING-RATIO } \\
\end{array}$ & $\begin{array}{l}: \\
\S \\
\S \\
\S \\
\text { HOT-WATER } \\
\text { HOT-WATER } \\
1.0 \\
\end{array}$ \\
\hline PLANT-ASSIGNMENT & See page 43 & \\
\hline
\end{tabular}

In addition to the keywords listed above, all keywords that apply to

Night Ventilation (SYSTEM-FANS command)

Add-On Evaporative Cooling (SYSTEM-EQUIPMENT command)

Add-On (Integrated) Desiccant Cooling (SYSTEM command)

Service Hot Water Heat Pump (SYSTEM and PLANT-ASSIGNMENT commands)

Electric and Fuel Meters (SYSTEM, ZONE, and PLANT-ASSIGNMENT commands)

Building Resources (PLANT-ASSIGNMENT commands)

apply to this system. 


\begin{tabular}{|c|c|c|}
\hline \multicolumn{3}{|c|}{ UVT-System Type: Unit Ventilator } \\
\hline Command & Keyword & Default Value or Consequence \\
\hline $\begin{array}{l}\text { ZONE-level } \\
\text { command }\end{array}$ & See pages 63,88 & $\cdot$ \\
\hline SYSTEM-CONTROL & $\begin{array}{l}\text { MAX-SUPPLY-T } \\
\text { HEATING-SCHEDULE } \\
\text { BASEBOARD-SCH } \\
\end{array}$ & $\begin{array}{l}105^{\circ} \mathrm{F} \\
\text { Always available } \\
\text { Always off } \\
\end{array}$ \\
\hline SYSTEM-AIR & $\begin{array}{l}\text { MIN-OUTSIDE-AIR } \\
\text { MIN-AIR-SCH } \\
\text { MAX-OA-FRACTION } \\
\end{array}$ & $\begin{array}{l}\text { From ZONE-AIR or none } \\
\text { No scheduling of outside air } \\
1.0\end{array}$ \\
\hline SYSTEM-FANS & $\begin{array}{l}\text { SUPPLY-STATIC } \\
\text { SUPPLY-EFF } \\
\text { SUPPLY-DELTA-T } \\
\text { SUPPLY-KW } \\
\text { FAN-SCHEDULE } \\
\text { NIGHT-CYCLE-CTRL }\end{array}$ & $\begin{array}{l}\text { From SUPPLY-DELTA-T \& SUPPLY-KW } \\
\text { From SUPPLY-DELTA-T \& SUPPLY-KW } \\
0.182^{\circ} \mathrm{F} \\
0.000059 \mathrm{~kW} / \mathrm{cfm} \\
\text { Always on } \\
\text { CYCLE-ON-ANY (no outside air) } \\
\end{array}$ \\
\hline SYSTEM-EQUIPMENT & $\begin{array}{l}\text { HEATING-CAPACITY } \\
\text { FURNACE-AUX } \\
\text { FURNACE-HIR } \\
\text { FURNACE-AUX-KW } \\
\text { FURNACE-HIR-FPLR } \\
\text { FURNACE-OFF-LOSS }\end{array}$ & $\begin{array}{l}\text { Dependent on peak loads } \\
800.0 \mathrm{Btu} / \mathrm{hr} \\
1.35 \mathrm{Btu} / \mathrm{Btu} \\
0.0 \mathrm{~kW} \\
\text { Standard curve SDL-Cill } \\
\text { No loss accounted for } \\
\end{array}$ \\
\hline SYSTEM & $\begin{array}{l}\text { SYSTEM-TYPE=UVT } \\
\text { ZONE-NAMES } \\
\text { SYSTEM-CONTROL } \\
\text { SYSTEM-AIR } \\
\text { SYSTEM-FANS } \\
\text { SYSTEM-EQUIPMENT } \\
\text { HEAT-SOURCE } \\
\text { BASEBOARD-SOURCE } \\
\text { SIZING-RATIO } \\
\end{array}$ & $\begin{array}{l}\bullet \\
\vdots \\
\S \\
\S \\
\S \\
\text { HOT-WATER } \\
\text { HOT-WATER } \\
1.0 \\
\end{array}$ \\
\hline PLANT-ASSIGNMENT & See page 43 & \\
\hline
\end{tabular}

In addition to the keywords listed above, all keywords that apply to

Night Ventilation (SYSTEM-FANS command)

Add-On Evaporative Cooling (SYSTEM-EQUIPMENT command)

Add-On (Integrated) Desiccant Cooling (SYSTEM command)

Service Hot Water Heat Pump (SYSTEM and PLANT-ASSIGNMENT commands)

Electric and Fuel Meters (SYSTEM, ZONE, and PLANT-ASSIGNMENT commands)

Building Resources (PLANT-ASSIGNMENT commands)

apply to this system.

- = Required keyword 


\begin{tabular}{|c|c|c|}
\hline \multicolumn{3}{|c|}{ FPH-System Type: Floor Panel Heating System } \\
\hline Command & Keyword & Default Value or Consequence \\
\hline ZONE-CONTROL & $\begin{array}{l}\text { DESIGN-HEAT-T } \\
\text { HEAT-TEMP-SCH } \\
\text { DESIGN-COOL-T } \\
\text { THERMOSTAT-TYPE } \\
\text { THROTTLING-RANGE }\end{array}$ & $\begin{array}{l}70^{\circ} \mathrm{F} \\
\text { No active heating control } \\
76^{\circ} \mathrm{F} \\
\text { PROPORTIONAL } \\
2^{\circ} \mathrm{F}\end{array}$ \\
\hline ZONE & $\begin{array}{l}\text { ZONE-CONTROL } \\
\text { ZONE-TYPE } \\
\text { MULTIPLIER } \\
\text { FLOOR-MULTIPLIER } \\
\text { MAX-HEAT-RATE } \\
\text { PANEL-LOSS-RATIO } \\
\text { SIZING-OPTION } \\
\text { TROM-VENT-SCH } \\
\end{array}$ & $\begin{array}{l}\S \\
\text { CONDITIONED } \\
\text { Taken from SPACE in LOADS } \\
\text { Taken from SPACE in LOADS } \\
\text { Peak load or } 1.08 \times \triangle \text { T } \times \text { CFM } \\
0.0 \\
\text { FROM-LOADS } \\
\text { (only if TROMBE-WALL-V specified) }\end{array}$ \\
\hline SYSTEM-CONTROL & HEATING-SCHEDULE & Always available \\
\hline SYSTEM & $\begin{array}{l}\text { SYSTEM-TYPE=FPH } \\
\text { ZONE-NAMES } \\
\text { SYSTEM-CONTROL } \\
\text { HEAT-SOURCE } \\
\text { SIZING-RATIO }\end{array}$ & $\begin{array}{l}\dot{\bullet} \\
\S \\
\text { HOT-WATER } \\
1.0\end{array}$ \\
\hline PLANT-ASSIGNMENT & See page 43 & \\
\hline
\end{tabular}

In addition to the keywords listed above, all keywords that apply to

Night Ventilation (SYSTEM-FANS command)

Add-On Evaporative Cooling (SYSTEM-EQUIPMENT command)

Add-On (Integrated) Desiccant Cooling (SYSTEM command)

Service Hot Water Heat Pump (SYSTEM and PLANT-ASSIGNMENT commands)

Electric and Fuel Meters (SYSTEM, ZONE, and PLANT-ASSIGNMENT commands)

Building Resources (PLANT-ASSIGNMENT commands)

apply to this system. 


\begin{tabular}{|c|c|c|}
\hline \multicolumn{3}{|c|}{ TPFC-System Type: Two Pipe Fan Coil System } \\
\hline Command & Keyword & Default Value or Consequence \\
\hline $\begin{array}{c}\text { ZONE-level } \\
\text { commands }\end{array}$ & \multicolumn{2}{|l|}{ See pages 63,88} \\
\hline SYSTEM-CONTROL & $\begin{array}{l}\text { MAX-SUPPLY-T } \\
\text { MIN-SUPPLY-T } \\
\text { HEATING-SCHEDULE } \\
\text { COOLING-SCHEDULE } \\
\text { MIN-HUMIDITY } \\
\text { BASEBOAFD-SCH }\end{array}$ & $\begin{array}{l}105^{\circ} \mathrm{F} \\
55^{\circ} \mathrm{F} \\
\text { Always available } \\
\text { Always available } \\
\text { No humidification } \\
\text { Always off }\end{array}$ \\
\hline SYSTEM-AIR & $\begin{array}{l}\text { MIN-OUTSIDE-AIR } \\
\text { MIN-AIR-SCH } \\
\text { DUCT-AIR-LOSS } \\
\text { DUCT-DELTA-T }\end{array}$ & $\begin{array}{l}\text { From ZONE-AIR or none } \\
\text { No scheduling of outside air } \\
\text { None } \\
\text { None }\end{array}$ \\
\hline SYSTEM-FANS & $\begin{array}{l}\text { SUPPLY-STATIC } \\
\text { SUPPLY-EFF } \\
\text { SUPPLY-DELTA-T } \\
\text { SUPPLY-IKW } \\
\text { FAN-SCHEDULE } \\
\text { NIGHT-CYCLE-CTRL }\end{array}$ & $\begin{array}{l}\text { From SUPPLY-DELTA-T \& SUPPLY-KW } \\
\text { From SUPPLY-DELTA-T \& SUPPLY-KW } \\
0.218^{\circ} \mathrm{F} \\
0.00007 \mathrm{~kW} / \mathrm{cm} \\
\text { Always on } \\
\text { STAY-OFF }\end{array}$ \\
\hline SYSTEM-EQUIPMENT & \multicolumn{2}{|l|}{ See page $114-115$} \\
\hline SYSTEM & $\begin{array}{l}\text { SYSTEM-TYPE=TPFC } \\
\text { ZONE-NAMES } \\
\text { SYSTEM-CONTROL } \\
\text { SYSTEM-AIR } \\
\text { SYSTEM-FANS } \\
\text { SYSTEM-EQUIPMENT } \\
\text { HEAT-SOURCE } \\
\text { BASEBOARD-SOURCE } \\
\text { SIZING-RATIO } \\
\end{array}$ & $\begin{array}{l}\bullet \\
\wp \\
\S \\
\S \\
\S \\
\text { HOT-WATER } \\
\text { HOT-WATER } \\
1.0 \\
\end{array}$ \\
\hline PLANT-ASSIGNMENT & See page 43 & - \\
\hline$\S$ Any keyword from this sub & and may be placed in the SYSTEN & mmand. \\
\hline
\end{tabular}

In addition to the keywords listed above, all keywords that apply to

Night Ventilation (SYSTEM-FANS command)

Add-On Evaporative Cooling (SYSTEM-EQUIPMENT command)

Add-On (Integrated) Desiccant Cooling (SYSTEM command)

Service Hot Water Heat Pump (SYSTEM and PLANT-ASSIGNMIENT commands)

Electric and Fuel Meters (SYSTEM, ZONE, and PLANT-ASSIGNMENT commands)

Building Resources (PLANT-ASSIGNMENT commands)

apply to this system. 


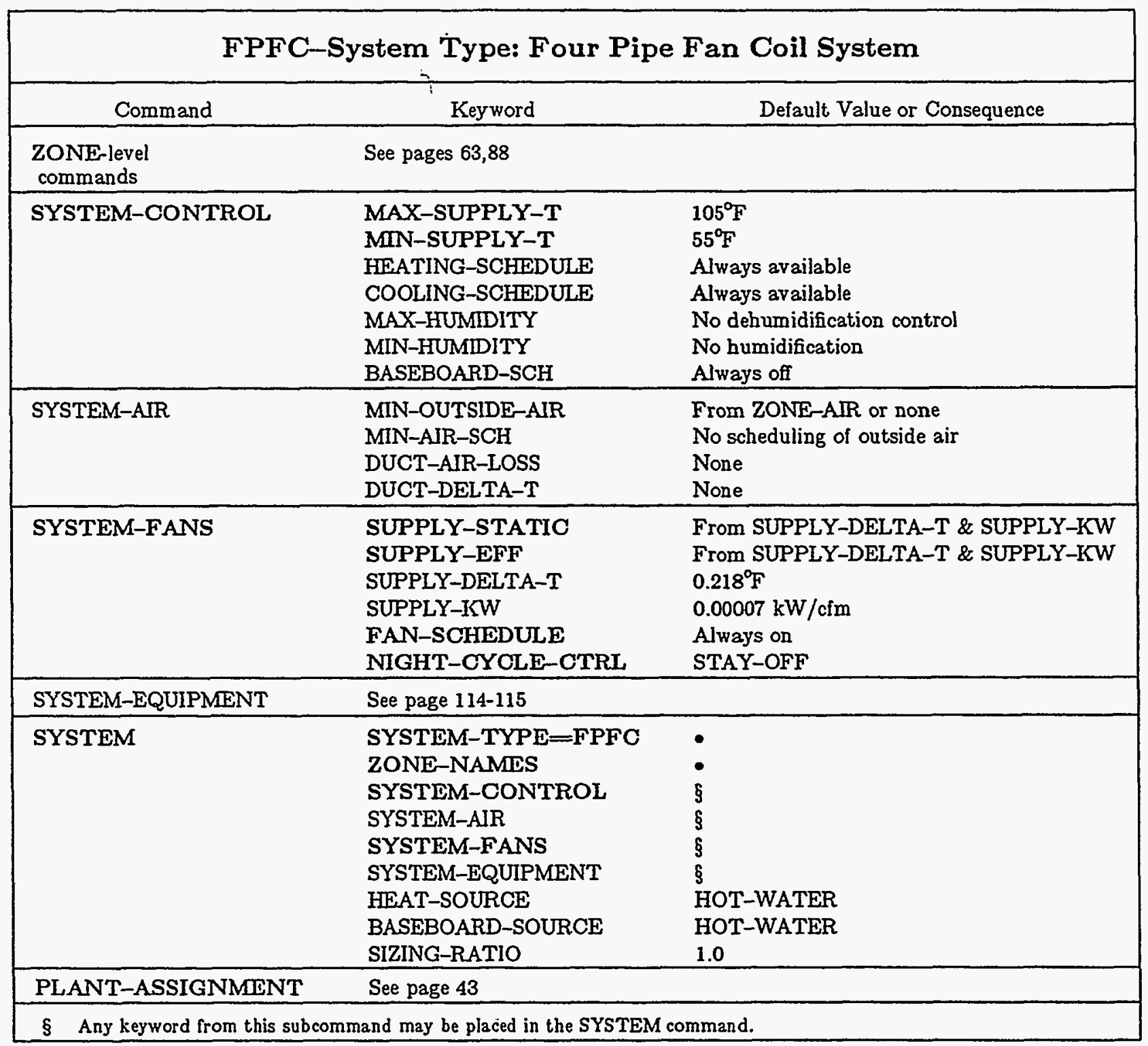




\begin{tabular}{|c|c|c|}
\hline \multicolumn{3}{|c|}{ TPIU-System Type: Two Pipe Induction Unit System } \\
\hline Command & Keyword & Default Value or Consequence \\
\hline $\begin{array}{l}\text { ZONE-level } \\
\text { commands }\end{array}$ & See pages 63,88 & \\
\hline SYSTEM-CONTROL & $\begin{array}{l}\text { MAX-SUPPLY-T } \\
\text { MIN-SUPPLY-T } \\
\text { HEATING-SCHEDULE } \\
\text { COOLING-SCHEDULE } \\
\text { COOL-CONTROL } \\
\text { COOL-SET-T } \\
\text { COOL-RESET-SCH } \\
\text { COOL-SET-SCH } \\
\text { HEAT-SET-T } \\
\text { PREHEAT-T } \\
\text { MAX-HUMIDITY } \\
\text { MIN-HUMIDITY } \\
\text { ECONO-LIMIT-T } \\
\text { ECONO-LOW-LIMIT } \\
\text { BASEBOARD-SCH } \\
\end{array}$ & $\begin{array}{l}105^{\circ} \mathrm{F} \\
55^{\circ} \mathrm{F} \\
\text { Always available } \\
\text { Always available } \\
\text { CONSTANT (RESET is NORMAL) } \\
\text { MIN-SUPPLY-T } \\
\text {-(only if COOL-CONTROL=RESET) } \\
\text {-(only if COOL-CONTROL=SCHEDULED) } \\
\text { From MIN-SUPPLY-T (SET=SUPPLY-HI) } \\
45^{\circ} \mathrm{F} \\
\text { No dehumidification control } \\
\text { No humidification } \\
\text { Return air temperature }- \text { changed in } 2.1 E \\
\text { No lower limit } \\
\text { Always of }\end{array}$ \\
\hline SYSTEM-AIR & $\begin{array}{l}\text { SUPPLY-CFM } \\
\text { RETURN-CFM } \\
\text { MIN-OUTSIDE-AIR } \\
\text { MIN-AIR-SCH } \\
\text { OA-CONTROL } \\
\text { MAX-OA-FRACTION } \\
\text { RECOVERY-EFF } \\
\text { DUCT-AIR-LOSS } \\
\text { DUCT-DELTA-T } \\
\end{array}$ & $\begin{array}{l}\text { From ZONE-AIR or load } / 1.08 \times \triangle T \\
\text { SUPPLY-CFM minus EXHAUST-CFM or } 0 \\
\text { From ZONE-AIR or none } \\
\text { No scheduling of outside air } \\
\text { TEMP } \\
1.0 \\
\text { No heat recovery simulated } \\
\text { None } \\
\text { None }\end{array}$ \\
\hline SYSTEM-FANS & $\begin{array}{l}\text { SUPPLY-STATIC } \\
\text { SUPPLY-EFF } \\
\text { SUPPLY-DELTA-T } \\
\text { SUPPLY-KW } \\
\text { FAN-SCHEDULE } \\
\text { SUPPLY-MECH-EFF } \\
\text { MOTOR-PLACEMENT } \\
\text { FAN-PLACEMENT } \\
\text { RETURN-STATIC } \\
\text { RETURN-EFF } \\
\text { RETURN-DELTA-T } \\
\text { RETURN-ISW } \\
\text { NIGHT-CYCLE-CTRL }\end{array}$ & $\begin{array}{l}\text { From SUPPLY-DELTA-T \& SUPPLY-KW } \\
\text { From SUPPLY-DELTA-T \& SUPPLY-KW } \\
4.467^{\circ} \mathrm{F} \\
0.001445 \mathrm{~kW} / \mathrm{cm} \\
\text { Always on } \\
\text { From SUPPLY-EFF } \\
\text { IN-AIRFLOW } \\
\text { DRAW-THROUGH } \\
\text { No return fan is simulated if neither pair } \\
\text { (RETURN-STATIC, RETURN-EFF) } \\
\text { or (RETURN-DELTA-T, RETURN-KW) } \\
\text { is specified. } \\
\text { STAY-OFF }\end{array}$ \\
\hline & & Continued on next page. \\
\hline
\end{tabular}




\begin{tabular}{|c|c|c|}
\hline \multicolumn{3}{|c|}{$\begin{array}{c}\text { Continuation of } \\
\text { TPIU-System Type: Two Pipe Induction Unit System }\end{array}$} \\
\hline Command & Keyword & Default Value or Consequence \\
\hline SYSTEM-TERMINAL & INDUCTION-RATIO & 3 \\
\hline SYSTEM-FLUID & INDUC-MODE-SCH & - \\
\hline SYSTEM-EQUIPMENT & See page 36 & \\
\hline SYSTEM & $\begin{array}{l}\text { SYSTEM-TYPE=TPIU } \\
\text { ZONE-NAMES } \\
\text { SYSTEM-CONTROL } \\
\text { SYSTEM-AIR } \\
\text { SYSTEM-FANS } \\
\text { SYSTEM-TERMINAL } \\
\text { SYSTEM-FLUID } \\
\text { SYSTEM-EQUIPMENT } \\
\text { HEAT-SOURCE } \\
\text { ZONE-HEAT-SOURCE } \\
\text { PREHEAT-SOURCE } \\
\text { BASEBOARD-SOURCE } \\
\text { HUMIDIFIER-TYPE } \\
\text { SIZING-RATIO } \\
\text { RETURN-AIR-PATH } \\
\text { PLENUM-NAMES } \\
\end{array}$ & $\begin{array}{l}\bullet \\
\S \\
\S \\
\S \\
\S \\
\S \\
\S \\
\text { HOT-WATER } \\
\text { HOT-WATER } \\
\text { HOT-WATER } \\
\text { HOT-WATER } \\
\text { HOT-WATER } \\
\text { 1.0 } \\
\text { DIRECT } \\
\text { No return air plenum }\end{array}$ \\
\hline PLANT-ASSIGNMENT & See page 43 & \\
\hline
\end{tabular}

In addition to the keywords listed above, all keywords that apply to

Night Ventilation (SYSTEM-FANS command)

Add-On Evaporative Cooling (SYSTEM-EQUIPMENT command)

Add-On (Integrated) Desiccant Cooling (SYSTEM command)

Service Hot Water Heat Pump (SYSTEM and PLANT-ASSIGNMENT commands)

Electric and Fuel Meters (SYSTEM, ZONE, and PLANT-ASSIGNMENT commands)

Building Resources (PLANT-ASSIGNMENT commands)

appiy to this system. 


\begin{tabular}{|c|c|c|}
\hline \multicolumn{3}{|c|}{ FPIU-System Type: Four Pipe Induction Unit System } \\
\hline Command & Keyword & Default Value or Consequence \\
\hline $\begin{array}{l}\text { ZONE-level } \\
\text { commands }\end{array}$ & See pages 63,88 & \\
\hline SYSTEM-CONTROL & $\begin{array}{l}\text { MAX-SUPPLY-T } \\
\text { MIN-SUPPLY-T } \\
\text { HEATING-SCHEDULE } \\
\text { COOLING-SCHEDULE } \\
\text { COOL-CONTROL } \\
\text { COOL-SET-T } \\
\text { COOL-RESET-SCH } \\
\text { COOL-SET-SCH } \\
\text { HEAT-SET-T } \\
\text { PREHEAT-T } \\
\text { MAX-HUMIITY } \\
\text { MIN-HUMIDITY } \\
\text { ECONO-LIMIT-T } \\
\text { ECONO-LOW-LIMIT } \\
\text { BASEBOARD-SCH } \\
\end{array}$ & $\begin{array}{l}105^{\circ} \mathrm{F} \\
50^{\circ} \mathrm{F} \\
\text { Always available } \\
\text { Always available } \\
\text { CONSTANT } \\
\text { MIN-SUPPLY-T } \\
\text { (only if COOL-CONTROL=RESET) } \\
\text { (only if COOL-CONTROL=SCHEDULED) } \\
\text { From MIN-SUPPLY-T } \\
45^{\circ} \mathrm{F} \\
\text { No dehumidification control } \\
\text { No humidification } \\
\text { Return air temperature }=\text { changed in } 2.1 \mathrm{E} \\
\text { No lower limit } \\
\text { Always off }\end{array}$ \\
\hline SYSTEM-AIR & $\begin{array}{l}\text { SUPPLY-CFM } \\
\text { RETURN-CFM } \\
\text { MIN-OUTSIDE-AIR } \\
\text { MIN-AIR-SCH } \\
\text { OA-CONTROL } \\
\text { MAX-OA-FRACTION } \\
\text { RECOVERY-EFF } \\
\text { DUCT-AIR-LOSS } \\
\text { DUCT-DELTA-T }\end{array}$ & $\begin{array}{l}\text { From ZONE-AIR or load/1.08 } \times \triangle T \\
\text { SUPPLY-CFM minus EXHAUST-CFM or } 0 \\
\text { From ZONE-AIR or none } \\
\text { No scheduling of outside air } \\
\text { TEMP } \\
1.0 \\
\text { No heat recovery simulated } \\
\text { None } \\
\text { None }\end{array}$ \\
\hline SYSTEM-FANS & $\begin{array}{l}\text { SUPPLY-STATIC } \\
\text { SUPPLY-EFF } \\
\text { SUPPLY-DELTA-T } \\
\text { SUPPLY-KW } \\
\text { FAN-SCHEDULE } \\
\text { SUPPLY-MECH-EFF } \\
\text { MOTOR-PLACEMENT } \\
\text { FAN-PLACEMENT } \\
\text { RETURN-STATIC } \\
\text { RETURN-EFF } \\
\text { RETURN-DELTA-T } \\
\text { RETURN-KW } \\
\text { NIGHT-CYCLE-CTRL }\end{array}$ & $\begin{array}{l}\text { From SUPPLY-DELTA-T \& SUPPLY-KW } \\
\text { From SUPPLY-DELTA-T \& SUPPLY-KW } \\
4.467^{\circ} \mathrm{F} \\
0.001445 \mathrm{~kW} / \mathrm{cfm} \\
\text { Always on } \\
\text { From SUPPLY-EFF } \\
\text { IN-AIRFLOW } \\
\text { DRAW-THROUGH } \\
\text { |No return fan is simulated if neither pair } \\
\text { (RETURN-STATIC, RETURN-EFF) } \\
\text { or (RETURN-DELTA-T, RETURN-KW) } \\
\text { is Specified. } \\
\text { STAY-OFF }\end{array}$ \\
\hline & & Continued on next page. \\
\hline
\end{tabular}


Continuation of

FPIU-System Type: Four Pipe Induction Unit System

\begin{tabular}{|c|c|c|}
\hline Command & Keyword & Default Value or Consequence \\
\hline SYSTEM-TERMINAL & INDUCTION-RATIO & 3 \\
\hline SYSTEM-EQUIPMENT & See page 36 & \\
\hline SYSTEM & $\begin{array}{l}\text { SYSTEM-TYPE=FPIU } \\
\text { ZONE-NAMES } \\
\text { SYSTEM-CONTROL } \\
\text { SYSTEM-AIR } \\
\text { SYSTEM-FANS } \\
\text { SYSTEM-TERMINAL } \\
\text { SYSTEM-EQUIPMENT } \\
\text { HEAT-SOURCE } \\
\text { ZONE-HEAT-SOURCE } \\
\text { PREHEAT-SOURCE } \\
\text { BASEBOARD-SOURCE } \\
\text { HUMIDIFIER-TYPE } \\
\text { SIZING-RATIO } \\
\text { RETURN-AIR-PATH } \\
\text { PLENUM-NAMES }\end{array}$ & $\begin{array}{l}\bullet \\
\wp \\
\S \\
\S \\
\S \\
\S \\
\S \\
\text { HOT-WATER } \\
\text { HOT-WATER } \\
\text { HOT-WATER } \\
\text { HOT-WATER } \\
\text { HOT-WATER } \\
\text { 1.0 } \\
\text { DIRECT } \\
\text { No Teturn air plenum }\end{array}$ \\
\hline PLANT-ASSIGNMENT & See page 43 & \\
\hline
\end{tabular}

In addition to the keywords listed above, all keywords that apply to

Night Ventilation (SYSTEM-FANS command)

Add-On Evaporative Cooling (SYSTEM-EQUIPMENT command)

Add-On (Integrated) Desiccant Cooling (SYSTEM command)

Service Hot Water Heat Pump (SYSTEM and PLANT-ASSIGNMENT commands)

Electric and Fuel Meters (SYSTEM, ZONE, and PLANT-ASSIGNMENT commands)

Building Resources (PLANT-ASSIGNMENT commands)

apply to this system. 


\begin{tabular}{|c|c|c|}
\hline \multicolumn{3}{|c|}{ VAVS-System Type: Variable Volume Fan System } \\
\hline Command & Keyword & Default Value or Consequence \\
\hline $\begin{array}{r}\text { ZONE-level } \\
\text { commands } \\
\end{array}$ & \multicolumn{2}{|l|}{ See pages 63,88} \\
\hline SYSTEM-CONTROL & $\begin{array}{l}\text { MAX-SUPPLY-T } \\
\text { MIN-SUPPLY-T } \\
\text { HEATING-SCHEDULE } \\
\text { COOLING-SCHEDULE } \\
\text { HEAT-SET-T } \\
\text { COOL-CONTROL } \\
\text { COOL-SET-T } \\
\text { COOL-RESET-SCH } \\
\text { COOL-SET-SCH } \\
\text { PREHEAT-T } \\
\text { MAX-HUMIDITY } \\
\text { MIN-HUMIDITY } \\
\text { ECONO-LIMIT-T } \\
\text { ECONO-LOW-LMIT } \\
\text { BASEBOARD-SCH } \\
\end{array}$ & $\begin{array}{l}\text { MIN-SUPPLY-T + REHEAT-DELTA-T } \\
55^{\circ} \mathrm{F} \\
\text { Always available } \\
\text { Always available } \\
\text { No capability to hold SAT reset or "warmest" } \\
\text { CONSTANT } \\
\text { MIN-SUPPL-T } \\
\text { (only if COOL-CONTROL=RESET) } \\
\text { (only if COOL-CONTROL=SCHEDULED) } \\
4^{\circ} \mathrm{F} \\
\text { No dehumidification control } \\
\text { No humidification } \\
\text { Return air temperature } \\
\text { No lower limit } \\
\text { Always off }\end{array}$ \\
\hline SYSTEM-AIR & $\begin{array}{l}\text { SUPPLY-CFM } \\
\text { RETURN-CFM } \\
\text { MIN-OUTSIDE-AIR } \\
\text { MIN-AIR-SCH } \\
\text { OA-CONTROL } \\
\text { MAX-OA-FRACTION } \\
\text { RECOVERY-EFF } \\
\text { DUCT-AIR-LOSS } \\
\text { DUCT-DELTA-T } \\
\end{array}$ & $\begin{array}{l}\text { From ZONE-AIR or load } / 1.08 \times \triangle T \\
\text { SUPPLY-CFM minus EXHAUST-CFM or } 0 \\
\text { From ZONE-AIR or none } \\
\text { No scheduling of outside air } \\
\text { TEMP } \\
1.0 \\
\text { No heat recovery simulated } \\
\text { None } \\
\text { None } \\
\end{array}$ \\
\hline \multirow[t]{2}{*}{ SYSTEM-FANS } & $\begin{array}{l}\text { SUPPLY-STATIC } \\
\text { SUPPLY-EFF } \\
\text { SUPPLY-DELTA-T } \\
\text { SUPPLY-KW } \\
\text { FAN-SCHEDULE } \\
\text { FAN-CONTROL } \\
\text { SUPPLY-MECH-EFF } \\
\text { MOTOR-PLACEMENT } \\
\text { FAN-PLACEMENT } \\
\text { MAX-FAN-RATIO } \\
\text { MIN-FAN-RATIO } \\
\text { RETURN-STATIC } \\
\text { RETURN-EFF } \\
\text { RETURN-DELTA-T } \\
\text { RETURN-IKW } \\
\text { NIGHT-CYCLE-CTRL } \\
\text { FAN-EIR-FPLR } \\
\end{array}$ & $\begin{array}{l}\text { From SUPPLY-DELTA-T \& SUPPLY-KW } \\
\text { From SUPPLY-DELTA-T \& SUPPLY-KW } \\
3.37^{\circ} \mathrm{F} \\
0.00109 \mathrm{~kW} / \mathrm{cfm} \\
\text { Always on } \\
\text { INLET } \\
\text { From SUPPLY-EFF } \\
\text { IN-AIRFLOW } \\
\text { DRAW-THROUGH } \\
1.1 \\
0.3 \\
\text { |No return fan is simulated if neither pair } \\
\text { (RETURN-STATIC, RETURN-EFF) } \\
\text { or (RETURN-DELTA-T, RETURN-KW) } \\
\text { is specified. } \\
\text { STAY-OFF } \\
\text { (only if FAN-CONTROL=FAN-EIR-FPLR) }\end{array}$ \\
\hline & \multicolumn{2}{|r|}{ Continued on next page. } \\
\hline$\$$ Any 1 & ind may be placed in the SY & ommand. \\
\hline
\end{tabular}

- = Required keyword 


\begin{tabular}{|c|c|c|}
\hline \multicolumn{3}{|c|}{$\begin{array}{l}\text { Continuation of } \\
\text { VAVS-System Type: Variable Volume Fan System }\end{array}$} \\
\hline Command & Keyword & Default Value or Consequence \\
\hline SYSTEM-TERMINAI & $\begin{array}{l}\text { REHEAT-DELTA-T } \\
\text { MIN-CFM-RATIO }\end{array}$ & $\begin{array}{l}\text { No reheat simulated } \\
\text { From outside air or heating load }\end{array}$ \\
\hline SYSTEM-EQUIPMENT & See page 36 & \\
\hline SYSTEM & $\begin{array}{l}\text { SYSTEM-TYPE=VAVS } \\
\text { ZONE-NAMES } \\
\text { SYSTEM-CONTROL } \\
\text { SYSTEM-AIR } \\
\text { SYSTEM-FANS } \\
\text { SYSTEM-TERMINAL } \\
\text { SYSTEM-EQUIPMENT } \\
\text { HEAT-SOURCE } \\
\text { ZONE-HEAT-SOURCE } \\
\text { PREHEAT-SOURCE } \\
\text { BASEBOARD-SOURCE } \\
\text { HUMIDIFIER-TYPE } \\
\text { SIZING-RATIO } \\
\text { SIZING-OPTION } \\
\text { RETURN-AIR-PATH } \\
\text { PLENUM-NAMES } \\
\end{array}$ & $\begin{array}{l}- \\
- \\
\$ \\
\$ \\
\$ \\
\$ \\
\$ \\
\text { HOT-WATER } \\
\text { HOT-WATER } \\
\text { HOT-WATER } \\
\text { HOT-WATER } \\
\text { HOT-WATER } \\
\text { 1.0 } \\
\text { NON-COINCIDENT } \\
\text { DUCT } \\
\text { No return air plenUm }\end{array}$ \\
\hline PLANT-ASSIGNMENT & See page 43 & \\
\hline
\end{tabular}

In addition to the keywords listed above, all keywords that apply to

Night Ventilation (SYSTEM-FANS command)

Add-On Evaporative Cooling (SYSTEM-EQUIPMENT command)

Add-On (Integrated) Desiccant Cooling (SYSTEM command)

Service Hot Water Heat Pump (SYSTEM and PLANT-ASSIGNMENT commands)

Electric and Fuel Meters (SYSTEM, ZONE, and PLANT-ASSIGNMENT commands)

Building Resources (PLANT-ASSIGNMENT commands)

apply to this system. 
PIU-System Type: Powered Induction Unit System

\begin{tabular}{|c|c|c|}
\hline Command & Keyword & Default Value or Consequence \\
\hline ZONE-CONTROL & $\begin{array}{l}\text { DESIGN-HEAT-T } \\
\text { HEAT-TEMP-SCH } \\
\text { DESIGN-COOL-T } \\
\text { COOL-TEMP-SCH } \\
\text { THERMOSTAT-TYPE } \\
\text { THROTTLING-RANGE } \\
\text { BASEBOARD-CTRL } \\
\end{array}$ & $\begin{array}{l}70^{\circ} \mathrm{F} \\
\text { No active heating control } \\
76^{\circ} \mathrm{F} \\
\text { No active cooling control } \\
\text { PROPORTIONAL } \\
2^{\circ} \mathrm{F} \\
\text { OUTDOOR-RESET } \\
\end{array}$ \\
\hline ZONE-AIR & $\begin{array}{l}\text { ASSIGNED-CFM } \\
\text { OFM/SQFT } \\
\text { AIR-CHANGES/HR } \\
\text { OUTSIDE-AIR-CFM } \\
\text { OA-CFM/PER } \\
\text { OA-CHANGES } \\
\text { EXHAUST-CFM } \\
\text { EXHAUST-EFF } \\
\text { EXHAUST-STATIC } \\
\text { EXHAUST-KW } \\
\end{array}$ & $\begin{array}{l}\text { Based on heating/cooling } \\
\text { loads,supply air, } \Delta \mathrm{T} \text {, and } \\
\text { sizing ratio } \\
\text { Based on MIN-OUTSIDE-AIR } \\
0.0 \\
0.75 \\
0.0 \\
\text { From EXHAUST-EFF and EXHAUST-STATIC }\end{array}$ \\
\hline ZONE-FANS & $\begin{array}{l}\text { ZONE-FAN-CFM } \\
\text { or } \\
\text { ZONE-FAN-RATIO } \\
\text { ZONE-FAN-KW } \\
\text { ZONE-FAN-T-SCH } \\
\end{array}$ & $\begin{array}{l}\text { PARALLEI-PIU, defaulting not allowed } \\
1.0 \text { for SERIES-PIU } \\
0.00033 \\
\text { ( (only for PARALLEL-PIU) }\end{array}$ \\
\hline ZONE & $\begin{array}{l}\text { ZONE-CONTROL } \\
\text { ZONE-AIR } \\
\text { ZONE-FANS } \\
\text { ZONE-TYPE } \\
\text { MULTIPLIER } \\
\text { FLOOR-MULTIPLIER } \\
\text { MAX-HEAT-RATE } \\
\text { MAX-COOL-RA_E } \\
\text { BASEBOARD-RATING } \\
\text { MIN-CFM-RATIO } \\
\text { MIN-CFM-SCH } \\
\text { SIZING-OPTION } \\
\text { TROM-VENT-SCH } \\
\text { TERMINAL-TYPE } \\
\text { INDUCED-AIR-ZONE } \\
\text { REHEAT-DILTA-T } \\
\end{array}$ & $\begin{array}{l}\S \\
\S \\
\S \\
\text { CONDITIONED } \\
\text { Taken from SPACE in LOADS } \\
\text { Taken from SPACE in LOADS } \\
\text { Peak load or } 1.08 \times \triangle \text { T } \times \text { CFM } \\
\text { Peak load or } 1.08 \times \triangle T \times C F M \\
\text { No baseboard heating } \\
\text { From SYSTEM-TERMINAL } \\
\text { MIN-CFM-RATIO } \\
\text { FROM-LOADS } \\
\text { (only if TROMBE-WALL-V specified) } \\
\text { SVAV } \dagger \\
\text { (only if TERMINAL-TYPE } \neq \text { SVAV) } \\
\text { No reheat to zone simulated }\end{array}$ \\
\hline SYSTEM-AIR & $\begin{array}{l}\text { SUPPLY-CFM } \\
\text { RETURN-CFM } \\
\text { MIN-OUTSIDE-AIR } \\
\text { MIN-AIR-SCH } \\
\text { OA-CONTROL } \\
\text { MAX-OA-FRACTION } \\
\text { RECOVERY-EFF } \\
\text { DUCT-AIR-LOSS } \\
\text { DUCT-DELTA-T } \\
\end{array}$ & $\begin{array}{l}\text { From ZONE-AIR or load/1.08X } \triangle T \\
\text { SUPPLY-CFM minus EXHAUST-CFM or } 0 \\
\text { From ZONE-AIR or none } \\
\text { No scheduling of outside air } \\
\text { TEMP } \\
1.0 \\
\text { No heat recovery simulated } \\
\text { None } \\
\text { None }\end{array}$ \\
\hline \multicolumn{3}{|c|}{$\begin{array}{l}\text { Because TERMINAL-TIPE defaults to SVAV, the zones with either Series-PIU or Parallel-PIU must be identified. } \\
\S \text { Any keyword from this subcommand may be placed in the SYSTEM command. }\end{array}$} \\
\hline & & Continued on next page. \\
\hline
\end{tabular}


SYSTEM TYPES

\begin{tabular}{|c|c|c|}
\hline \multicolumn{3}{|c|}{$\begin{array}{c}\text { Continuation of } \\
\text { PIU-System Type: Powered Induction Unit System }\end{array}$} \\
\hline Command & Keyword & Default Value or Consequence \\
\hline SYSTEM-CONTROL & $\begin{array}{l}\text { MAX-SUPPLY-T } \\
\text { MIN-SUPPLY-T } \\
\text { HEATING-SCHEDULE } \\
\text { COOLING-SCHEDULE } \\
\text { HEAT-SET-T } \\
\text { COOL-CONTROL } \\
\text { COOL-SET-T } \\
\text { COOL-RESET-SCH } \\
\text { COOL-SET-SCH } \\
\text { PREHEAT-T } \\
\text { MAX-HUMIDITY } \\
\text { MIN-HUMIDITY } \\
\text { ECONO-LIMIT-T } \\
\text { ECONO-LOW-LIMIT } \\
\text { BASEBOARD-SCH } \\
\end{array}$ & $\begin{array}{l}\text { MIN-SUPPLY-T + REHEAT-DELTA-T } \\
55^{\circ} \mathrm{F} \\
\text { Always available } \\
\text { Always available } \\
\text { No main heating coil capacity } \\
\text { CONSTANT } \\
\text { MIN-SUPPLY-T } \\
\text {-(only if COOL-CONTROL=RESET) } \\
\text {-(only if COOL-CONTROL=SCHEDULED) } \\
45^{\circ} \mathrm{F} \\
\text { No dehumidification control } \\
\text { No humidification } \\
\text { Return air temperature changed in } 2.1 \mathrm{C} \\
\text { No lower limit } \\
\text { Always of }\end{array}$ \\
\hline SYSTEM-FANS & $\begin{array}{l}\text { SUPPLY-STATIC } \\
\text { SUPPLY-EFF } \\
\text { SUPPLY-DELTA-T } \\
\text { SUPPLY-KW } \\
\text { FAN-SCHEDULE } \\
\text { FAN-CONTROL } \\
\text { SUPPLY-MECH-EFF } \\
\text { MOTOR-PLACEMENT } \\
\text { FAN-PLACEMENT } \\
\text { MAX-FAN-RATIO } \\
\text { MIN-FAN-RATIO } \\
\text { RETURN-STATIC } \\
\text { RETURN-EFF } \\
\text { RETURN-DELTA-T } \\
\text { RETURN-KW } \\
\text { NIGHT-CYCLE-CTRL } \\
\text { FAN-EIR-FPLR } \\
\end{array}$ & $\begin{array}{l}\text { From SUPPLY-DELTA-T \& SUPPLY-KW } \\
\text { From SUPPLY-DELTA-T \& SUPPLY-KW } \\
3.37^{\circ} \mathrm{F} \\
0.00109 \mathrm{~kW} / \mathrm{cfm} \\
\text { Always on } \\
\text { INLET } \\
\text { From SUPPLY-EFF } \\
\text { IN-AIRFLOW } \\
\text { DRAW-THROUGH } \\
1.1 \\
0.3 \\
\text { No return fan is simulated if neither pair } \\
\text { (RETURN-STATIC, RETURN-EFF) } \\
\text { or (RETURN-DELTA-T, RETURN-KW) } \\
\text { is Specified. } \\
\text { STAY-OFF } \\
\text { (only if FAN-CONTROL=FAN-EIR-FPLR) }\end{array}$ \\
\hline \multicolumn{3}{|c|}{8 Any keyword from this subcommand may be placed in the SYSTEM command. } \\
\hline & & Continued on next page. \\
\hline
\end{tabular}


Continuation of

PIU-System Type: Powered Induction Unit System

\begin{tabular}{|c|c|c|}
\hline Command & Keyword & Default Value or Consequence \\
\hline SYSTEM-TERMINAL & $\begin{array}{l}\text { REHEAT-DELTA-T } \\
\text { MIN-CFM-RATIO }\end{array}$ & $\begin{array}{l}\text { No reheat simulated } \\
\text { From outside air or heating load }\end{array}$ \\
\hline SYSTEM-EQUIPMENT & See page 36 & \\
\hline SYSTEM & $\begin{array}{l}\text { SYSTEM-TYPE=PIU } \\
\text { ZONE-NAMES } \\
\text { SYSTEM-CONTROL } \\
\text { SYSTEM-AIR } \\
\text { SYSTEM-FANS } \\
\text { SYSTEM-TERMINAL } \\
\text { SYSTEM-EQUIPMENT } \\
\text { HEAT-SOURCE } \\
\text { ZONE-HEAT-SOURCE } \\
\text { PREHEAT-SOURCE } \\
\text { BASEBOARD-SOURCE } \\
\text { HUMIDIFIER-TYPE } \\
\text { SIZING-RATIO } \\
\text { SIZING-OPTION } \\
\text { RETURN-AIR-PATH } \\
\text { PLENUM-NAMES }\end{array}$ & $\begin{array}{l}\bullet \\
\vdots \\
\$ \\
\S \\
\S \\
\xi \\
\text { HOT-WATER } \\
\text { HOT-WATER } \\
\text { HOT-WATER } \\
\text { HOT-WATER } \\
\text { HOT-WATER } \\
\text { 1.0 } \\
\text { NON-COINCIDENT } \\
\text { DUCT } \\
\text { No Ieturn air Plenum }\end{array}$ \\
\hline PLANT-ASSIGNMENT & See page 43 & \\
\hline
\end{tabular}

In addition to the keywords listed above, all keywords that apply to

Night Ventilation (SYSTEM-FANS command)

Add-On Evaporative Cooling (SYSTEM-EQUIPMENT command)

Add-On (Integrated) Desiccant Cooling (SYSTEM command)

Service Hot Water Heat Pump (SYSTEM and PLANT-ASSIGNMENT commands)

Electric and Fuel Meters (SYSTEM, ZONE, and PLANT-ASSIGNMENT commands)

Building Resources (PLANT-ASSIGNMENT commands)

apply to this system.

$\bullet=$ Required keyword 


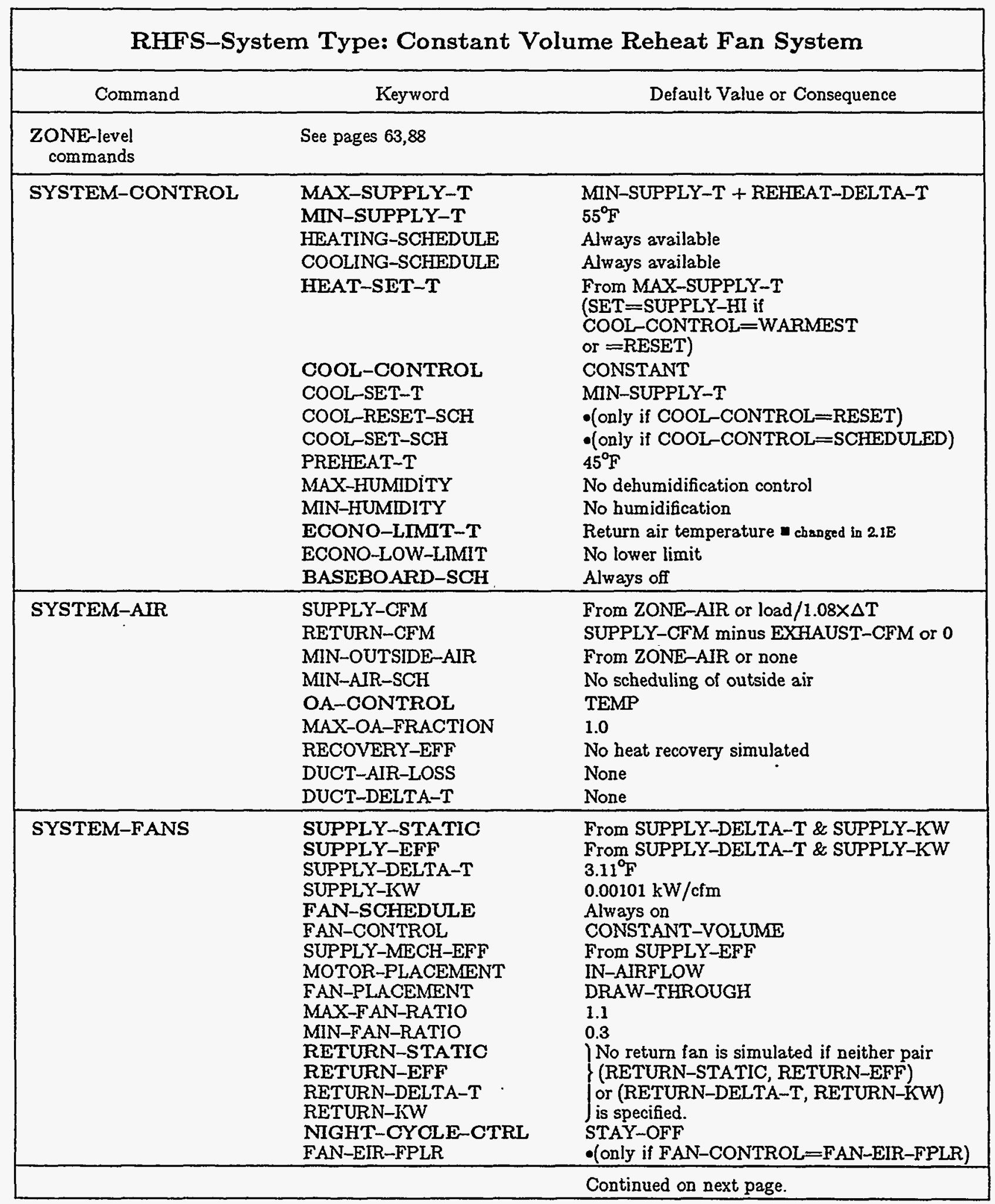


Continuation of

RHFS-System Type: Constant Volume Reheat Fan System

\begin{tabular}{|lll|}
\hline \multicolumn{1}{|c|}{ Command } & \multicolumn{1}{c|}{ Keyword } & Default Value or Consequence \\
\hline SYSTEM-TERMINAL & REHEAT-DELTA-T & $50^{\circ} \mathrm{F}$ \\
\hline SYSTEM-EQUIPMENT & See page 36 & \\
\hline SYSTEM & SYSTEM-TYPE=RHFS & $\bullet$ \\
& ZONE-NAMES & $\bullet$ \\
& SYSTEM-CONTROL & $\S$ \\
& SYSTEM-AIR & $\S$ \\
& SYSTEM-FANS & $\S$ \\
& SYSTEM-TERMINAL & $\S$ \\
& SYSTEM-EQUIPMENT & $\S$ \\
& HEAT-SOURCE & HOT-WATER \\
& ZONE-HEAT-SOURCE & HOT-WATER \\
& PREHEAT-SOURCE & HOT-WATER \\
& BASEBOARD-SOURCE & HOT-WATER \\
& HUMIDIFIER-TYPE & HOT-WATER \\
& SIZING-RATIO & 1.0 \\
& SIZING-OPTION & NON-COINCIDENT \\
& RETURN-AIR-PATH & DUCT \\
& PLENUM-NAMES & No return air plenum \\
& See Page 43 & \\
\hline PLANT-ASSIGNMENT & & \\
\hline \$ Any keyword from this subcommand & may be placed in the SYSTEM command. \\
\hline
\end{tabular}

In addition to the keywords listed above, all keywords that apply to

Night Ventilation (SYSTEM-FANS command)

Add-On Evaporative Cooling (SYSTEM-EQUIPMENT command)

Add-On (Integrated) Desiccant Cooling (SYSTEM command)

Service Hot Water Heat Pump (SYSTEM and PLANT-ASSIGNMENT commands)

Electric and Fuel Meters (SYSTEM, ZONE, and PLANT-ASSIGNMENT commands)

Building Resources (PLANT-ASSIGNMENT commands)

apply to this system. 
ZONE-level Commands and Keywords

\begin{tabular}{|c|c|c|}
\hline \multicolumn{3}{|c|}{ HP-System Type: Water Loop Heat Pump System } \\
\hline Command & Keyword & Default Value or Consequence \\
\hline $\begin{array}{l}\text { ZONE-level } \\
\text { commands }\end{array}$ & See pages 63,88 & \\
\hline SYSTEM-CONTROL & $\begin{array}{l}\text { MAX-SUPPLY-T } \\
\text { MIN-SUPPLY-T } \\
\text { HEATING-SCHEDULE } \\
\text { COOLING-SCHEDULE } \\
\text { BASEBOARD-SCH } \\
\text { ECONO-LIMIT-T } \\
\text { DRYBULB-LIMIT } \\
\text { ENTHALPY-LIMT } \\
\text { ECONO-LOW-LIMIT }\end{array}$ & $\begin{array}{l}105.0 \\
55.0 \\
\text { Always available } \\
\text { Always available } \\
\text { Always of } \\
\text { - Return air temperature } \\
\text { Return air temperature } \\
\text { Rone } \\
\text { - None }\end{array}$ \\
\hline SYSTEM-AIR & $\begin{array}{l}\text { MIN-OUTSIDE-AIR } \\
\text { MIN-AIR-SCH } \\
\text { RATED-CFM } \\
\text { VENT-TEMP-SCH } \\
\text { OA-CONTROL } \\
\text { RECOVERY-EFF } \\
\text { MAX-OA-FRACTION }\end{array}$ & $\begin{array}{l}\text { From ZONE-AIR or none } \\
\text { No scheduling of outside air } \\
\text { No performance adjustment } \\
\text { HEAT-TEMP-SCH + } \\
.5 * \text { THROTTLING-RANGE } \\
\text { Fixed } \\
0.0 \text { no recovery } \\
01.0 \\
\end{array}$ \\
\hline SYSTEM-FANS & $\begin{array}{l}\text { SUPPLY-STATIC } \\
\text { SUPPLY-EFF } \\
\text { SUPPLY-DELTA-T } \\
\text { SUPPLY-KW } \\
\text { FAN-SCHEDULE } \\
\text { FAN-CONTROL } \\
\text { NIGHT-CYCLE-CTRL } \\
\text { NIGHT-VENT-CTRL } \\
\text { NIGHT-VENT-SCH } \\
\\
\text { NIGHT-VENT-DT } \\
\text { NIGHT-VENT-RATIOS } \\
\end{array}$ & $\begin{array}{l}\text { From SUPPLY-DELTA-T \& SUPPLY-KW } \\
\text { From SUPPLY-DELTA-T \& SUPPLY-KW } \\
0.218^{\circ} \mathrm{F} \\
0.00007 \mathrm{~kW} / \mathrm{cm} \\
\text { Always on } \\
\text { CYCLING if OA-CONTROL=FLXED, } \\
\text { else CONSTANT-VOLUME } \\
\text { STAY-OFF } \\
\text { NOT-AVAILABLE } \\
\text { Required keyword } \\
\text { (only if N-V-C=WHEN-SCHEDULED } \\
\text { or SCHEDULED+DEMAND; } \\
\text { otherwise, unused) } \\
5.0^{\circ} \mathrm{F} \\
\text { - (only if N-V-C } \neq \text { NOT-AVAILABLE) } \\
\end{array}$ \\
\hline SYSTEM-FLUID & $\begin{array}{l}\text { MIN-FLUID-T } \\
\text { MAX-FLUID-T } \\
\text { FLUID-VOLUME } \\
\text { COND-FLOW-TYPE } \\
\text { COND-WTR-FLOW } \\
\end{array}$ & $\begin{array}{l}\text { default to PLANT-ASSIGNMENT values } \\
\text { default to PLANT-ASSIGNMENT values } \\
\text { default to PLANT-ASSIGNMENT values } \\
\text { FLXED-FLOW } \\
\text { a } 3.0 \mathrm{gpm} \\
\end{array}$ \\
\hline & & Continued on next page. \\
\hline
\end{tabular}




\begin{tabular}{|c|c|c|}
\hline \multicolumn{3}{|c|}{$\begin{array}{l}\text { Continuation of } \\
\text { HP-System Type: Water Loop Heat Pump System }\end{array}$} \\
\hline Command & Keyword & Default Value or Consequence \\
\hline SYSTEM-EQUIPMENT & $\begin{array}{l}\text { COOLING-CAPACITY } \\
\text { COOI-CAP-FT } \\
\text { COOLING-EIR } \\
\text { COOL-EIR-FT } \\
\text { COOL-EIR-FPLR } \\
\text { COOL_SH-CAP } \\
\text { COOL_SH-FT } \\
\text { COIL-BF } \\
\text { COIL_BF-FCFM } \\
\text { COIL-BF-FT } \\
\text { RATED-CCAP-FCFM } \\
\text { RATED-CEIR-FCFM } \\
\text { RATED-SH-FCFM } \\
\text { RATED-HCAP-FCFM } \\
\text { RATED-HEIR-FCFM } \\
\text { HEATING-CAPACITY } \\
\text { HEAT-CAP-FT } \\
\text { HEATING-EIR } \\
\text { HEAT-EIR-FT } \\
\text { HEAT-EIR-FPLR }\end{array}$ & $\begin{array}{l}\text { Dependent on peak loads } \\
\text { Standard curve SDL-C5 } \\
0.382 \text { Btu/Btu } \\
\text { Standard curve SDI-C15 } \\
\text { Standard curve SDI-C20 } \\
\text { From loads } \\
\text { Standard curve SDL-C25 } \\
0.241 \\
\text { Standard curve SDI-C35 } \\
\text { Standard curve SDI-C45 } \\
\text { Standard curve SDI-C79 } \\
\text { Standard curve SDI-C94 } \\
\text { Standard curve SDI-C86 } \\
\text { Standard curve SDL-C101 } \\
\text { Standard curve SDL-C109 } \\
\text { Dependent on peak loads } \\
\text { Standard curve SDI-C55 } \\
\text { 0.357 Btu/Btu } \\
\text { Standard curve SDI-C60 } \\
\text { Standard curve SDI-C65 }\end{array}$ \\
\hline SYSTEM & $\begin{array}{l}\text { SYSTEM-TYPE=HP } \\
\text { ZONE-NAMES } \\
\text { SYSTEM-CONTROL } \\
\text { SYSTEM-AIR } \\
\text { SYSTEM-FANS } \\
\text { SYSTEM-FLUID } \\
\text { SYSTEM-EQUTMENT } \\
\text { BASEBOARD-SOURCE } \\
\text { SIZING-RATIO } \\
\end{array}$ & $\begin{array}{l}: \\
\S \\
\S \\
\S \\
\S \\
\S \\
\text { HOT-WATER } \\
1.0 \\
\end{array}$ \\
\hline PLANT-ASSIGNMENT & See page 43 & \\
\hline
\end{tabular}

In addition to the keywords listed above, all keywords that apply to

Night Ventilation (SYSTEM-FANS command)

Add-On Evaporative Cooling (SYSTEM-EQUIPMENT command)

Add-On (Integrated) Desiccant Cooling (SYSTEM command)

Service Hot Water Heat Pump (SYSTEM and PLANT-ASSIGNMENT commands)

Electric and Fuel Meters (SYSTEM, ZONE, and PLANT-ASSIGNMENT commands)

Building Resources (PLANT-ASSIGNMENT commands)

apply to this system.

$\bullet \doteq$ Required keyword $\quad-89-\quad \square=$ Added/changed in $2.1 \mathrm{E}$ 
SYSTEM TYPES

\begin{tabular}{|c|c|c|}
\hline \multicolumn{3}{|c|}{ HVSYS-System Type: Heating and Ventilating System } \\
\hline Command & Keyword & Default Value or Consequence \\
\hline $\begin{array}{l}\text { ZONE-level } \\
\text { commands }\end{array}$ & See pages 63,88 & \\
\hline \multirow[t]{7}{*}{ SYSTEM-CONTROL } & $\begin{array}{l}\text { MAX-SUPPLY-T } \\
\text { HEATING-SCHEDULE } \\
\text { HEAT-CONTROL }\end{array}$ & $\begin{array}{l}105^{\circ} \mathrm{F} \\
\text { Always available } \\
\text { CONSTANT (RESET is LIKELY OPTION) }\end{array}$ \\
\hline & HEAT-SET-T & $\begin{array}{l}\text { From MAX-SUPPLY-T, or if } \\
\text { HEAT-CONTROL=CONSTANT, then } \\
\text { weighted average DESIGN-HEAT-T }\end{array}$ \\
\hline & HEAT-RESET-SCH & -(only if HEAT-CONTROL=RESET) \\
\hline & & \\
\hline & ECONO-LIMIT-T & Return air temperature $\square$ \\
\hline & ECONO-LOW-LIMIT & No lower limit \\
\hline & BASEBOARD-SCH & Always off \\
\hline \multirow[t]{3}{*}{ SYSTEM-AIR } & $\begin{array}{l}\text { SUPPLY-CFM } \\
\text { RETURN-CFM } \\
\text { MIN-OUTSIDE-AIR } \\
\text { MIN-AIR-SCH }\end{array}$ & $\begin{array}{l}\text { From ZONE-AIR or load } / 1.08 \times \Delta T \\
\text { SUPPLY-CFM minus EXHAUST-CFM or } 0 \\
\text { From ZONE-AIR or none } \\
\text { No scheduling of outside air }\end{array}$ \\
\hline & OA-CONTROL & TEMP \\
\hline & $\begin{array}{l}\text { MAX-OA-FRACTION } \\
\text { RECOVERY-EFF } \\
\text { DUCT-AIR-LOSS } \\
\text { DUCT-DELTA-T } \\
\end{array}$ & $\begin{array}{l}1.0 \\
\text { No heat recovery simulated } \\
\text { None } \\
\text { None }\end{array}$ \\
\hline \multirow[t]{6}{*}{ SYSTEM-FANS } & $\begin{array}{l}\text { SUPPLY-STATIC } \\
\text { SUPPLY-EFF }\end{array}$ & $\begin{array}{l}\text { From SUPPLY-DELTA-T \& SUPPLY-KW } \\
\text { From SUPPLY-DELTA-T \& SUPPLY-KW }\end{array}$ \\
\hline & $\begin{array}{l}\text { SUPPLY-DELTA-T } \\
\text { SUPPLY-KW } \\
\text { FAN-SCHEDULE } \\
\text { MOTOR-PLACEMENT }\end{array}$ & $\begin{array}{l}2.42^{\circ} \mathrm{F} \\
0.000783 \mathrm{~kW} / \mathrm{cim} \\
\text { Always on } \\
\text { IN-AIRFLOW }\end{array}$ \\
\hline & $\begin{array}{l}\text { RETURN-STATIC } \\
\text { RETURN-EFF } \\
\text { RETURN-DELTA-T } \\
\text { RETURN-KW }\end{array}$ & $\begin{array}{l}\text { No return fan is simulated if neither pair } \\
\text { (RETURN-STATIC, RETURN-EFF) } \\
\text { or (RETURN-DELTA-T, RETURN-KW) } \\
\text { is specified. }\end{array}$ \\
\hline & NIGHT-CYCLE-CTRL & STAY-OFF \\
\hline & $\begin{array}{l}\text { NGGHT-VENT-CTRL } \\
\text { NGHT-VENT-SCH }\end{array}$ & $\begin{array}{l}\text { NOT-AVAILABLE } \\
\text { (only if } N-V-C=\text { WHEN-SCHEDURED or }\end{array}$ \\
\hline & $\begin{array}{l}\text { NIGHT-VENT-DT } \\
\text { NIGHT-VENT-RATIOS }\end{array}$ & $\begin{array}{l}5.0^{\circ} \mathrm{F} \\
-(\text { only if } \mathrm{N}-\mathrm{V}-\mathrm{C} \neq \mathrm{NOT}-\mathrm{AVAILABLE})\end{array}$ \\
\hline SYSTEM-TERMINAL & REHEAT-DELTA-T & No reheat simulated \\
\hline \multirow[t]{5}{*}{ SYSTEM-EQUIPMENT } & HEATING-CAPACITY & Dependent on peak loads \\
\hline & FURNACE-AUX & $800.0 \mathrm{Btu} / \mathrm{hr}$ \\
\hline & $\begin{array}{l}\text { FURNACE-AUX-KW } \\
\text { FURNACE-HIR }\end{array}$ & $1.35 \mathrm{Btu} / \mathrm{Btu}$ \\
\hline & $\begin{array}{l}\text { FURNACE-HIR-FPLR } \\
\text { FURNACE-OFF-LOSS }\end{array}$ & $\begin{array}{l}\text { Standard curve SDL-C111 } \\
\text { No loss accounted for }\end{array}$ \\
\hline & & Continued on next page. \\
\hline
\end{tabular}

- = Required keyword

$-90-$

$\omega=$ Added/changed in $2.1 \mathrm{E}$ 
Continuation of

HVSYS-System Type: Heating and Ventilating System

\begin{tabular}{|c|c|c|}
\hline Command & Keyword & Default Value or Consequence \\
\hline SYSTEM & $\begin{array}{l}\text { SYSTEM-TYPE=HVSYS } \\
\text { ZONE-NAMES } \\
\text { SYSTEM-CONTROL } \\
\text { SYSTEM-AIR } \\
\text { SYSTEM-FANS } \\
\text { SYSTEM-TERMINAL } \\
\text { SYSTEM-EQUIPMENT } \\
\text { HEAT-SOURE } \\
\text { ZONE-HEAT-SOURCE } \\
\text { BASEBOARD-SOURCE } \\
\text { HUMIDIFIER-TYPE } \\
\text { SIZING-RATIO } \\
\text { RETURN-AIR-PATH } \\
\text { PLENUM-NAMES } \\
\end{array}$ & $\begin{array}{l}: \\
\dot{5} \\
\S \\
\$ \\
\$ \\
\S \\
\text { HOT-WATER } \\
\text { HOT-WATER } \\
\text { HOT-WATER } \\
\text { HOT-WATER } \\
1.0 \\
\text { DIRECT } \\
\text { No return air plenum } \\
\end{array}$ \\
\hline PLANT-ASSIGNMENT & See page 43 & \\
\hline
\end{tabular}

In addition to the keywords listed above, all keywords that apply to

Night Ventilation (SYSTEM-FANS command)

Add-On Evaporative Cooling (SYSTEM-EQUIPMENT command)

Add-On (Integrated) Desiccant Cooling (SYSTEM command)

Service Hot Water Heat Pump (SYSTEM and PLANT-ASSIGNMENT commands)

Electric and Fuel Meters (SYSTEM, ZONE, and PLANT-ASSIGNMENT commands)

Building Resources (PLANT-ASSIGNMENT commands)

apply to this system. 


\begin{tabular}{|c|c|c|}
\hline \multicolumn{3}{|c|}{ CBVAV-System Type: Ceiling Bypass System } \\
\hline Command & Keyword & Default Value or Consequence \\
\hline $\begin{array}{l}\text { ZONE-level } \\
\text { commands }\end{array}$ & \multicolumn{2}{|l|}{ See pages 63,88} \\
\hline \multirow[t]{7}{*}{ SYSTEM-CONTROL } & $\begin{array}{l}\text { MAX-SUPPLY-T } \\
\text { MIN-SUPPLY-T }\end{array}$ & $\begin{array}{l}\text { MIN-SUPPLY-T+REHEAT-DELTA-T } \\
55^{\circ} \mathrm{F}\end{array}$ \\
\hline & $\begin{array}{l}\text { HEATING-SCHEDULE } \\
\text { COOLING-SCHEDULE } \\
\text { HEAT-SET-T }\end{array}$ & $\begin{array}{l}\text { Always available } \\
\text { Always available } \\
\text { No main heating coil capacity }\end{array}$ \\
\hline & COOL-CONTROL & CONSTANT \\
\hline & $\begin{array}{l}\text { COOL_SET-T } \\
\text { COOL-RESET-SCH } \\
\text { COOL-SET-SCH } \\
\text { PREHEAT-T } \\
\text { MAX-HUMIDITY } \\
\text { MIN-HUMIDITY }\end{array}$ & $\begin{array}{l}\text { MIN-SUPPLY-T } \\
\text { (only if COOL-CONTROL=RESET) } \\
\text { (Only if COOL-CONTROL=SCHEDULED) } \\
45^{\circ} \mathrm{F} \\
\text { No dehumidification control } \\
\text { No humidification }\end{array}$ \\
\hline & ECONO-LIMIT-T . & a Return air temperature \\
\hline & ECONO-LOW-LIMIT & No lower limit \\
\hline & BASEBOARD-SCH & Always off \\
\hline \multirow[t]{6}{*}{ SYSTEM-AIR } & SUPPLY-CFM & From ZONE-AIR or load/1.08 $\times \Delta \mathrm{T}$ \\
\hline & $\begin{array}{l}\text { RETURN-CFM } \\
\text { MIN-OUTSIDE-AIR } \\
\text { MIN-AIR-SCH }\end{array}$ & $\begin{array}{l}\text { SUPPLY-CFM minus EXHAUST-CFM or } 0 \\
\text { From ZONE-AIR or none } \\
\text { No scheduling of outside air }\end{array}$ \\
\hline & OA-CONTROL & TEMP \\
\hline & $\begin{array}{l}\text { MAX-OA-FRACTION } \\
\text {-RECOVERY-EFF }\end{array}$ & $\begin{array}{l}1.0 \\
\text { No heat recovery simulated }\end{array}$ \\
\hline & $\begin{array}{l}\text { DUCT-AIR-LOSS } \\
\text { DUCT-DELTA-T }\end{array}$ & $\begin{array}{l}\text { None } \\
\text { None }\end{array}$ \\
\hline & & Continued on next page. \\
\hline
\end{tabular}


Continuation of

\section{CBVAV-System Type: Ceiling Bypass System}

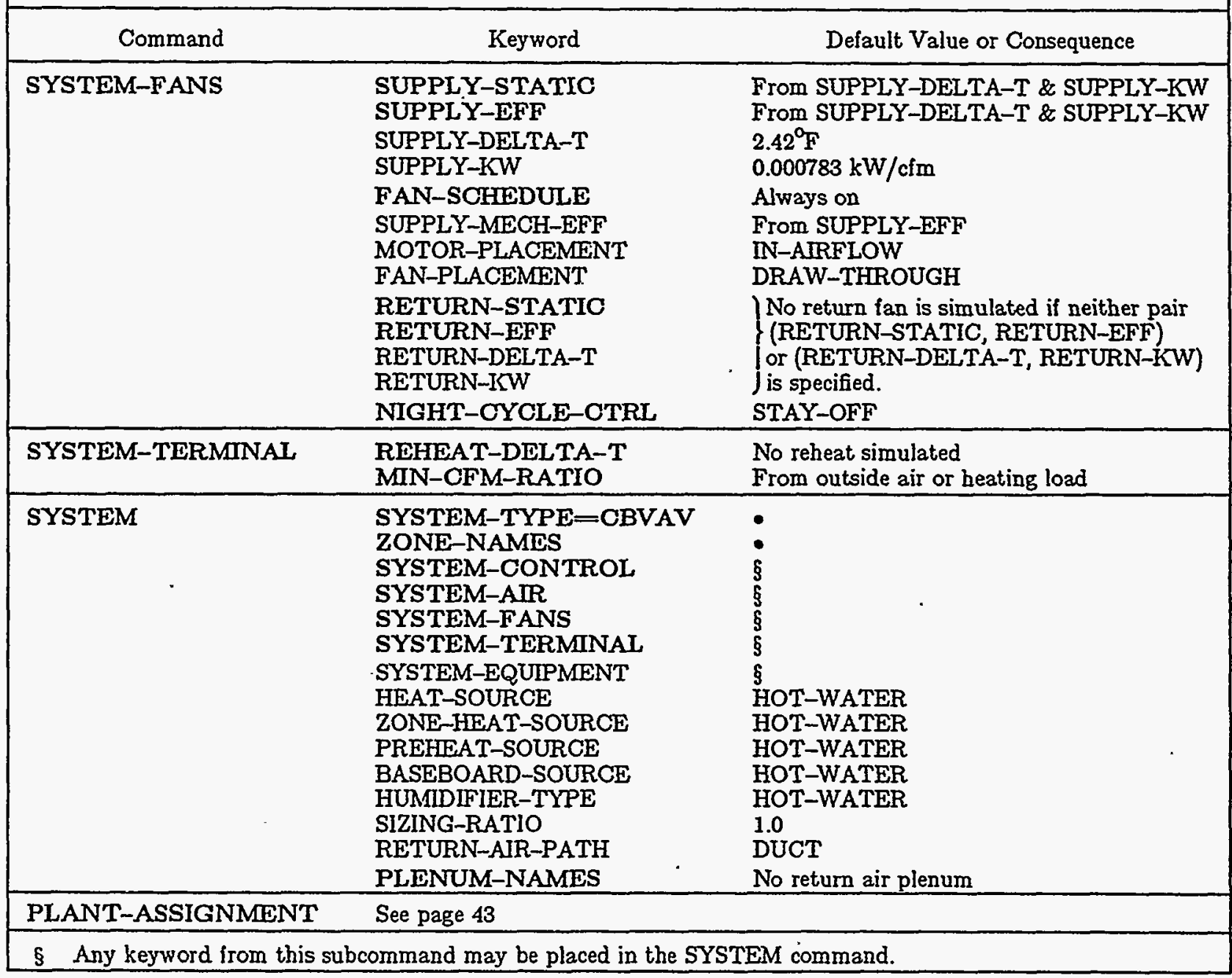

In addition to the keywords listed above, all keywords that apply to

Night Ventilation (SYSTEM-FANS command)

Add-On Evaporative Cooling (SYSTEM-EQUIPMENT command)

Add-On (Integrated) Desiccant Cooling (SYSTEM command)

Service Hot Water Heat Pump (SYSTEM and PLANT-ASSIGNMENT commands)

Electric and Fuel Meters (SYSTEM, ZONE, and PLANT-ASSIGNMENT commands)

Building Resources (PLANT-ASSIGNMENT commands)

apply to this system.

- = Required keyword 


\begin{tabular}{|c|c|c|}
\hline \multicolumn{3}{|c|}{ RESYS-System Type: Residential System } \\
\hline Command & Keyword & Default Value or Consequence \\
\hline ZONE-CONTROL & $\begin{array}{l}\text { DESIGN-HEAT-T } \\
\text { HEAT-TEMP-SCH } \\
\text { DESIGN-COOL-T } \\
\text { COOL-TEMP-SCH } \\
\text { THERMOSTAT-TYPE } \\
\text { THROTTLING-RANGE } \\
\text { BASEBOARD-CTRL }\end{array}$ & $\begin{array}{l}\text { - but not used } \\
\text { - but not used } \\
\text { PROPORTIONAL } \\
2 \text { F } \\
\text { OUTDOOR-RESET }\end{array}$ \\
\hline ZONE-AIR & $\begin{array}{l}\text { ASSIGNED-CFM } \\
\text { CFM/SQFT } \\
\text { AIR-CHANGES/HR } \\
\text { SS-VENT-SCH } \\
\text { SS-VENT-T-SCH } \\
\text { SS-VENT-CST } \\
\text { SS-VENT-WND } \\
\text { SS-VENT-TEMP } \\
\text { SS-VENT-LIMIT-T } \\
\text { SS-VENT-IWW } \\
\text { SS-FLOW-SCH } \\
\end{array}$ & $\begin{array}{l}\text { Based on heating/cooling } \\
\text { loads, supply air, } \Delta \mathrm{T} \text {,and } \\
\text { sizing ratio } \\
\text { No venting of sunspace } \\
\text { No variation in venting } \\
5.0 \text { ach } \\
0.01 / \mathrm{knot} \\
0.01 / \mathrm{O}^{\circ} \mathrm{F} \\
120.0^{\circ} \mathrm{F} \\
0.0 \\
\text { No multiplied air flow effect }\end{array}$ \\
\hline ZONE & $\begin{array}{l}\text { ZONE-CONTROL } \\
\text { ZONE-AIR } \\
\text { ZONE-TYPE } \\
\text { BASEBOARD-RATING } \\
\text { SIZING-OPTION } \\
\text { TROM-VENT-SCH } \\
\end{array}$ & $\begin{array}{l}\S \\
\S \\
\text { CONDITIONED } \\
\text { No baseboard heating } \\
\text { FROM-LOADS } \\
\text { - (only if TROMBE-WALL-V specified) }\end{array}$ \\
\hline SYSTEM-CONTROL & $\begin{array}{l}\text { MAX-SUPPLY-T } \\
\text { MIN-SUPPLY-T } \\
\text { HEATING-SCHEDULE } \\
\text { COOLING-SCHEDULE } \\
\text { BASEBOARD-SCH } \\
\end{array}$ & $\begin{array}{l}105^{\circ} \mathrm{F} \\
55^{\circ} \mathrm{F} \\
\text { Always available } \\
\text { Always available } \\
\text { Always off } \\
\end{array}$ \\
\hline SYSTEM-AIR & $\begin{array}{l}\text { SUPPLY-CFM } \\
\text { DUCT-AIR-LOSS } \\
\text { DUCT-DELTA-T } \\
\text { VENT-METHOD } \\
\text { MAX-VENT-RATE } \\
\text { HOR-VENT-FRAC } \\
\text { FRAC-FRAC-AREA } \\
\text { OPER-FRAC-SCH } \\
\text { NATURAL-VENT-AC } \\
\text { NATURAL-VENT-SCH } \\
\text { VENT-TEMP-SCH } \\
\end{array}$ & $\begin{array}{l}\text { From loads or capacities } \\
\text { None } \\
\text { None } \\
\text { AIR-CHANGE } \\
20 \\
\text { None } \\
0.5 \\
\text { u-name } \\
\text { No natural ventilation } \\
\text { No natural ventilation } \\
\text { HEAT-TEMP-SCH } \\
\end{array}$ \\
\hline \multirow[t]{2}{*}{ SYSTEM } & $\begin{array}{l}\text { SYSTEM-TYPE==RESYS } \\
\text { ZONE-NAMES } \\
\text { SYSTEM-CONTROL } \\
\text { SYSTEM-AIR } \\
\text { SYSTEM-FANS } \\
\text { SYSTEM-EQUIPMENT } \\
\text { HEAT-SOURCE } \\
\text { BASEBOARD-SOURCE } \\
\text { SIZING-RATIO } \\
\text { EVAP-PCC-EFF } \\
\text { EVAP-PCC-SCH }\end{array}$ & $\begin{array}{l}\text { - (First listed must be control zone) } \\
\S \\
\S \\
\S \\
\S \\
\text { GAS-FURNACE (HEAT-PUMP is OPTION) } \\
\text { ELECTRIC } \\
1.0 \\
8 \\
\text { (see u-name) } \\
\end{array}$ \\
\hline & & Continued next page \\
\hline$\S$ Any keyword from $t$ & ommand may be placed in the & NE command. \\
\hline
\end{tabular}


Continuation of

RESYS-System Type: Residential System

\begin{tabular}{|c|c|c|}
\hline Command & Keyword & Default Value or Consequence \\
\hline SYSTEM-EQUIPMENT & 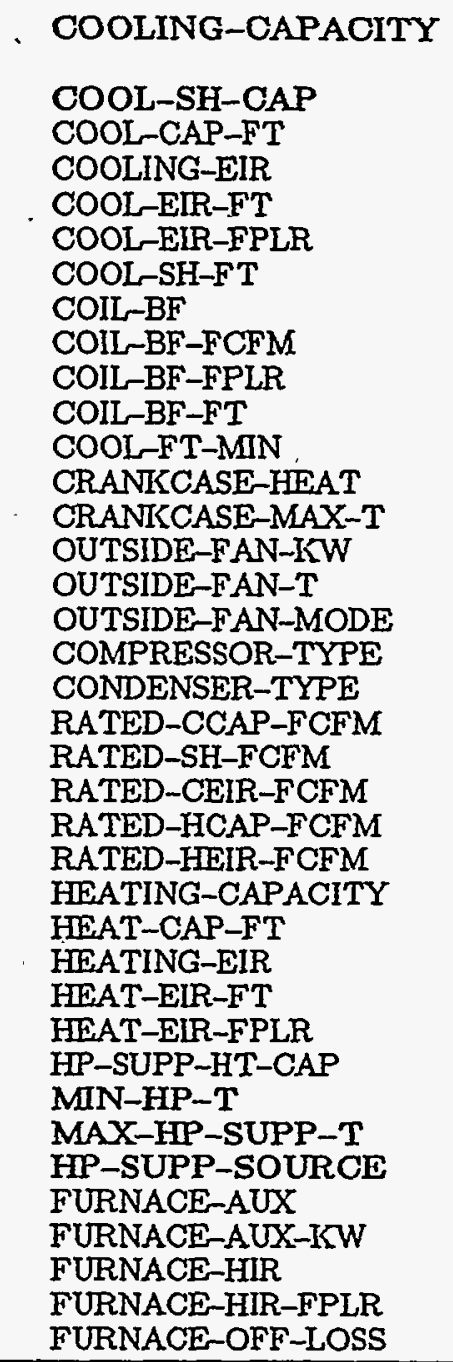 & 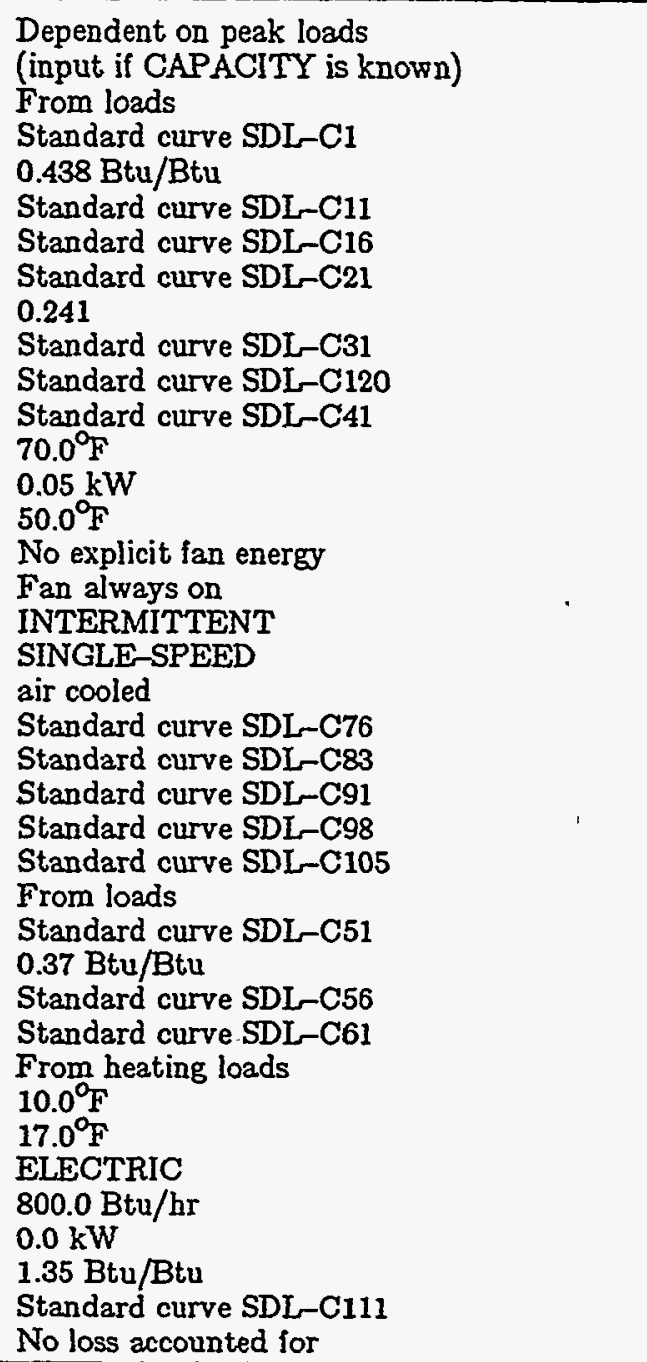 \\
\hline SYSTEM-FANS & $\begin{array}{l}\text { SUPPLY-STATIC } \\
\text { SUPPLY-EFF } \\
\text { SUPPLY-DELTA-T } \\
\text { SUPPLY-IKW } \\
\text { FAN-SCHEDULE } \\
\text { LOW-SPEED-RATIOS }\end{array}$ & $\begin{array}{l}\text { From SUPPLY-DELTA-T \& SUPPLY-KW } \\
\text { From SUPPLY-DELTA-T \& SUPPLY-KW } \\
0.396^{\circ} \mathrm{F} \\
0.000128 \mathrm{~kW} / \mathrm{cm} \text {. } \\
\text { Always on } \\
\text { - if COMPRESSOR-TYPE=DUAL-SPEED }\end{array}$ \\
\hline PLANT-ASSIGNMENT & See page 43 & \\
\hline
\end{tabular}

In addition to the above, all keywords that apply to the following, also apply to RESYS.

Night Ventilation (SYSTEM-FANS command)

Add-On (Integrated) Desiccant Cooling (SYSTEM command)

Service Hot Water Heat Pump (SYSTEM and PLANT-ASSIGNMENT commands)

Electric and Fuel Meters (SYSTEM, ZONE, and PLANT-ASSIGNMENT commands)

Building Resources (PLANT-ASSIGNMENT commands) 


\begin{tabular}{|c|c|c|}
\hline \multicolumn{3}{|c|}{ PSZ-System Type: Packaged Single Zone System } \\
\hline Command & Keyword & Default Value or Consequence \\
\hline ZONE-CONTROL & $\begin{array}{l}\text { DESIGN-HEAT-T } \\
\text { HEAT-TEMP-SCH } \\
\text { DESIGN-COOL-T } \\
\text { COOL-TEMP-SCH } \\
\text { THERMOSTAT-TYPE } \\
\text { THROTTLING-RANGE } \\
\text { BASEBOARD-CTRL } \\
\end{array}$ & $\begin{array}{l}\text { No active heating control } \\
\text { No active cooling control } \\
\text { PROPORTIONAL } \\
2^{\circ} \mathrm{F} \\
\text { OUTDOOR-RESET }\end{array}$ \\
\hline ZONE-AIR & $\begin{array}{l}\text { ASSIGNED-CFM } \\
\text { CFM/SQFT } \\
\text { AIR-CHANGES/HR } \\
\text { OUTSIDE-AIR-CFM } \\
\text { OA-CFM/PER } \\
\text { OA-CHANGES } \\
\text { EXHAUST-CFM } \\
\text { EXHAUST-EFF } \\
\text { EXHAUST-STATIC } \\
\text { EXHAUST-KW } \\
\end{array}$ & $\begin{array}{l}\text { Based on heating/cooling } \\
\text { loads, supply air, } \Delta \mathrm{T}, \\
\text { and sizing ratio } \\
\text { Based on MIN-OUTSDE-AIR } \\
0.0 \\
0.75 \\
0.0 \\
\text { From EXIHAUST-EFF and EXIHAUST-STATIC }\end{array}$ \\
\hline ZONE & $\begin{array}{l}\text { ZONE-CONTROL } \\
\text { ZONE-AIR } \\
\text { ZONE-TYPE } \\
\text { MULTIPLIER } \\
\text { FLOOR-MULTIPLIER } \\
\text { MAX-HEAT-RATE } \\
\text { MAX-COOL-RATE } \\
\text { BASEBOARD-RATING } \\
\text { HEATING-CAPACITY } \\
\text { COOLING-CAPACITY } \\
\text { COOL-SH-CAP } \\
\text { MIN-CFM-RATIO } \\
\text { MIN-CFM-SCH } \\
\text { SIZING-OPTION } \\
\text { TROM-VENT-SCH } \\
\end{array}$ & $\begin{array}{l}\S \\
\S \\
\text { CONDITIONED } \\
\text { Taken from SPACE in LOADS } \\
\text { Taken from SPACE in LOADS } \\
\text { Peak load or } 1.08 \times \triangle \text { TXCFM } \\
\text { Peak load or } 1.08 \times \triangle \text { TXCFM } \\
\text { No baseboard heating } \\
\text { From SYSTEM-EQUIPMENT } \\
\text { From SYSTEM-TERMINAL } \\
\text { MIN-CFM-RATIO } \\
\text { FROM-LOADS } \\
\text { (only if TROMBE-WALL-V specified) }\end{array}$ \\
\hline SYSTEM-CONTROL & $\begin{array}{l}\text { MAX-SUPPLY-T } \\
\text { MIN-SUPPLY-T } \\
\text { HEATING-SCHEDULE } \\
\text { COOLING-SCHEDULE } \\
\text { MAX-HUMIDITY } \\
\text { MIN-HUMIDITY } \\
\text { ECONO-LIMIT-T } \\
\text { ECONO-LOCIIOUT } \\
\text { ECONO-LOW-LIMIT } \\
\text { WS-ECONO } \\
\text { WS-ECONO-MIN-DT } \\
\text { BASEBOARD-SCH } \\
\end{array}$ & $\begin{array}{l}\text { Always available } \\
\text { Always available } \\
\text { No dehumidification control } \\
\text { No humidification } \\
\text { Return air temperature } \\
\text { YES - Compressor off w/OA dampers open } \\
\text { No lower limit } \\
\text { NO } \\
5^{\circ} \mathrm{F} \\
\text { Always off }\end{array}$ \\
\hline SYSTEM-AIR & $\begin{array}{l}\text { SUPPLY-CFM } \\
\text { RETURN-CFM } \\
\text { MIN-OUTSIDE-AIR } \\
\text { MIN-AIR-SCH } \\
\text { OA-CONTROL } \\
\text { MAX-OA-FRACTION } \\
\text { RECOVERY-EFF } \\
\text { DUCT-AIR-LOSS } \\
\text { DUCT-DELTA-T }\end{array}$ & $\begin{array}{l}\text { From ZONE-AIR or load/1.08 } \times \triangle T \\
\text { SUPPLY-CFM minus EXHAUST-CFM or } 0 \\
\text { From ZONE-AIR or none } \\
\text { No scheduling of outside air } \\
\text { TEMP } \\
1.0 \\
\text { No heat recovery simulated } \\
\text { None } \\
\text { None }\end{array}$ \\
\hline
\end{tabular}


Continuation of

PSZ-System Type: Packaged Single Zone System

\begin{tabular}{|c|c|c|}
\hline Command & Keyword & Default Value or Consequence \\
\hline SYSTEM-FANS & $\begin{array}{l}\text { SUPPLY-STATIC } \\
\text { SUPPLY-EFF } \\
\text { SUPPLY-DELTA-T } \\
\text { SUPPLY-KW } \\
\text { FAN-SCHEDULE } \\
\text { FAN-CONTROL } \\
\text { SUPPLY-MECH-EFF } \\
\text { MOTOR-PLACEMENT } \\
\text { FAN-PLACEMENT } \\
\text { MAX-FAN-RATIO } \\
\text { MIN-FAN-RATIO } \\
\text { RETURN-STATIC } \\
\text { RETURN-EFF } \\
\text { RETURN-DELTA-T } \\
\text { RETURN-KW } \\
\text { NIGHT-CYCLE-CTRL } \\
\text { FAN-EIR-FPLR } \\
\text { INDOOR-FAN-MODE }\end{array}$ & $\begin{array}{l}\text { From SUPPLY-DELTA-T \& SUPPLY-KW } \\
\text { From SUPPLY-DELTA-T \& SUPPLY-KW } \\
1.815^{\circ} \mathrm{F} \\
0.000587 \mathrm{~kW} / \mathrm{cfm} \\
\text { Always on } \\
\text { CONSTANT-VOLUME } \\
\text { From SUPPLY-EFF } \\
\text { IN-AIRFLOW } \\
\text { DRAW-THROUGH } \\
\text { 1.1 } \\
\text { 0.3 } \\
\text { No return fan is simulated if neither pair } \\
\text { (RETURN-STATIC, RETURN-EFF) } \\
\text { or (RETURN-DELTA-T, RETURN-KW) } \\
\text { ) is specified. } \\
\text { STAY-OFF } \\
\text { (only if FAN-CONTROL=FAN-EIR-FPLR) } \\
\text { Continuous }\end{array}$ \\
\hline SYSTEM-TERMINAL & $\begin{array}{l}\text { REHEAT-DELTA-T } \\
\text { MIN-CFM-RATIO }\end{array}$ & $\begin{array}{l}\text { No reheat simulated } \\
\text { Constant volume system }\end{array}$ \\
\hline SYSTEM & $\begin{array}{l}\text { SYSTEM-TYPE=PSZ } \\
\text { ZONE-NAMES } \\
\text { SYSTEM-CONTROL } \\
\text { SYSTEM-AIR } \\
\text { SYSTEM-FANS } \\
\text { SYSTEM-TERMMNAL } \\
\text { SYSTEM-EQUIPMENT } \\
\text { HEAT-SOURCE } \\
\\
\text { ZONE-HEAT-SOURCE } \\
\text { BASEBOARD-SOURCE } \\
\text { HUMIDIFIER-TYPE } \\
\text { SIZING-RATIO } \\
\text { SIZING-OPTION } \\
\text { RETURN-AIR-PATH } \\
\text { PLENUM-NAMES }\end{array}$ & $\begin{array}{l}\bullet \text { (First listed must be control zone) } \\
\S \\
\S \\
\S \\
\S \\
\S \\
\text { GAS-FURNACE } \\
\text { (HEAT-PUMP, ELECTRIC, and } \\
\text { GAS-HEAT-PUMP are OPTIONs) } \\
\text { ELECTRIC } \\
\text { ELECTRIC } \\
\text { ELECTRIC } \\
1.0 \\
\text { NON-COINCIDENT } \\
\text { DIRECT } \\
\text { No return air plenum }\end{array}$ \\
\hline SYSTEM-EQUIPMENT & $\begin{array}{l}\text { MIN-HP-T } \\
\text { MAX-HP-SUPP-T } \\
\text { HP-SUPP-SOURCE } \\
\text { FURNACE-AUX } \\
\text { FURNACE-AUX-IW } \\
\text { FURNACE-HIR } \\
\text { FURNACE-HIR-FPLR } \\
\text { FURNACE-OFF-LOSS } \\
\text { REFG-IW-FTCOND } \\
\text { REFG-IWW-FPLR } \\
\text { TWR-RFACT-FRT } \\
\text { TWR-APP-FRFACT }\end{array}$ & $\begin{array}{l}15.0^{\circ} \mathrm{F} \\
40.0^{\circ} \mathrm{F} \\
\text { ELECTRIC } \\
800.0 \mathrm{Btu} / \mathrm{hr} \\
0.0 \mathrm{~kW} \\
1.35 \mathrm{Btu} / \mathrm{Btu} \\
\text { Standard curve SDL-C111 } \\
\text { No loss accounted for } \\
\text { Standard curve SDL-C112 } \\
\text { Standard curve SDL-C113 } \\
\text { Standard curve SDL-C114 } \\
\text { Standard curve SDL-C115 }\end{array}$ \\
\hline & & Continued on next page. \\
\hline
\end{tabular}




\begin{tabular}{|c|c|c|}
\hline \multicolumn{3}{|c|}{ PSZ-System Type: Packaged Single Zone System } \\
\hline Command & Keyword & Default Value or Consequence \\
\hline SYSTEM-EQUIPMENT & $\begin{array}{l}\text { COOLING-CAPACITY } \\
\text { COOL-SH-CAP } \\
\text { COOL-CAP-FT } \\
\text { COOLING-EIR } \\
\text { COOL-EIR-FT } \\
\text { COOL-EIR-FPLR } \\
\text { COOL-SH-FT } \\
\text { COII-BF } \\
\text { COIL-BF-FCFM } \\
\text { COIL-BF-FT } \\
\text { COII-BF-FPLR } \\
\text { COOL-FT-MIN } \\
\text { MIN-SUPPLY-SCH } \\
\text { MIN-UNLOAD-RATIO } \\
\text { MIN-HGB-RATIO } \\
\text { MAX-COND-RCVRY } \\
\text { CONDENSER-TYPE } \\
\text { WS-ECONO-XEFF } \\
\text { CRANIKCASE-HEAT } \\
\text { CRANIKCASE-MAX-T } \\
\text { OUTSIDE-FAN-KW } \\
\text { OUTSIDE-FAN-T } \\
\text { OUTSIDE-FAN-MODE } \\
\text { RATED-CCAP-FCFM } \\
\text { RATED-SH-FCFM } \\
\text { RATED-CEIR-FCFM } \\
\text { RATED-HCAP-FCFM } \\
\text { HEATING-CAPACITY } \\
\text { HEAT-CAP-FT } \\
\text { HEATING-EIR } \\
\text { HEAT-EIR-FT } \\
\text { HEAT-EIR-FPLR } \\
\text { HP-SUPP-HT-CAP }\end{array}$ & 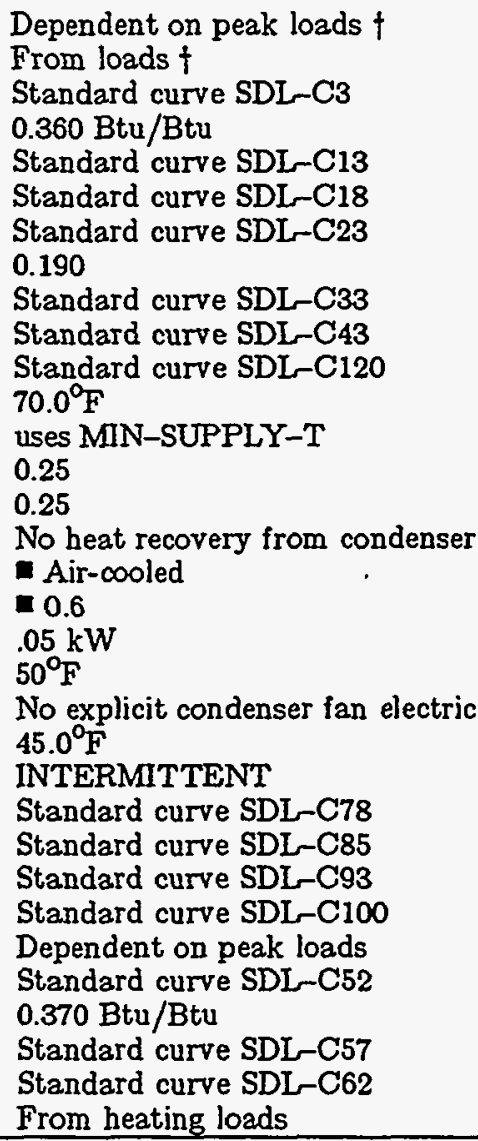 \\
\hline PLANT-ASSIGNMENT & See page 43 & \\
\hline $\begin{array}{ll}\dagger & \text { Input if CAPACITY is } \\
\& & \text { Any keyword from this }\end{array}$ & & \\
\hline
\end{tabular}

In addition to the keywords above, all keywords that apply to the following, also apply to this system. For watercooled condensers that apply to PSZ systems, see the PLANT-ASSIGNMENT keywords that control the size of both tower and circulating pumps; see SYSTEM-FLUID for condenser flow variables.

Refrigerated Casework

Defrost Controls

Air and Water Side Economizers

Air and Water Cooled Condensers

Night Ventilation (SYSTEM-FANS command)

Add-On Evaporative Cooling (SYSTEM-EQUIPMENT command)

Add-On (Integrated) Desiccant Cooling (SYSTEM command)

Service Hot Water Heat Pump (SYSTEM and PLANT-ASSIGNMENT commands)

Electric and Fuel Meters (SYSTEM, ZONE, and PLANT-ASSIGNMENT commands)

Building Resources (PLANT-ASSIGNMENT commands) 
SYSTEM TYPES

\begin{tabular}{|c|c|c|}
\hline \multicolumn{3}{|c|}{ PMZS-System Type: Packaged Multi-Zone System } \\
\hline Command & ,Keyword & Default Value or Consequence \\
\hline $\begin{array}{l}\text { ZONE-level } \\
\text { commands }\end{array}$ & See pages 63,88 & $\begin{array}{l}\text { (Input HEATING and COOLING } \\
\text { capacity when known) }\end{array}$ \\
\hline SYSTEM-CONTROL & $\begin{array}{l}\text { MAX-SUPPLY-T } \\
\text { MIN-SUPPLY-T } \\
\text { HEATING-SCHEDULE } \\
\text { COOLING-SCHEDULE } \\
\text { HEAT-CONTROL } \\
\text { HEAT-SET-T } \\
\text { HEAT-RESET-SCH } \\
\text { HEAT-SET-SCH } \\
\text { COOL-CONTROL } \\
\text { COOL-SET-T } \\
\text { COOL-RESET-SCH } \\
\text { COOL-SET-SCH } \\
\text { MAX-HUMIDITY } \\
\text { MIN-HUMIDITY } \\
\text { ECONO-LIMIT-T } \\
\text { ECONO-LOCKOUT } \\
\text { ECONO-LOW-LIMIT } \\
\text { BASEBOARD-SCH }\end{array}$ & $\begin{array}{l}\text { - } \\
\text { Always available } \\
\text { Always available } \\
\text { CONSTANT } \\
\text { From MAX-SUPPLY-T } \\
\text { (only if HEAT-CONTROL=RESET) } \\
\text { (only if HEAT-CONTROL=SCHEDULED) } \\
\text { CONSTANT } \\
\text { MIN-SUPPLY-T } \\
\text { (only if COOL-CONTROL=RESET) } \\
\text { (only if COOL-CONTROL=SCHEDULED) } \\
\text { No dehumidification control } \\
\text { No humidification } \\
\text { Return air temperature }= \\
\text { NO - Compressor runs w/OA dampers open } \\
\text { No lower limit } \\
\text { Always off }\end{array}$ \\
\hline SYSTEM-AIR & $\begin{array}{l}\text { SUPPLY-CFM } \\
\text { RETURN-CFM } \\
\text { MIN-OUTSIDE-AIR } \\
\text { MIN-AIR-SCH } \\
\text { OA-CONTROL } \\
\text { MAX-OA-FRACTION } \\
\text { RECOVERY-EFF } \\
\text { DUCT-AIR-LOSS } \\
\text { DUCT-DELTA-T } \\
\end{array}$ & $\begin{array}{l}\text { From ZONE-AIR or load } / 1.08 \times \Delta T \\
\text { SUPPLY-CFM minus EXHAUST-CFM or } 0 \\
\text { From ZONE-AIR or none } \\
\text { No scheduling of outside air } \\
\text { TEMP } \\
1.0 \\
\text { No heat recovery simulated } \\
\text { None } \\
\text { None }\end{array}$ \\
\hline SYSTEM-FANS & $\begin{array}{l}\text { SUPPLY-STATIC } \\
\text { SUPPLY-EFF } \\
\text { SUPPLY-DELTA-T } \\
\text { SUPPLY-KW } \\
\text { FAN-SCHEDULE } \\
\text { FAN-CONTROL } \\
\text { SUPPLY-MECH-EFF } \\
\text { MOTOR-PLACEMENT } \\
\text { MAX-FAN-RATIO } \\
\text { MIN-FAN-RATIO } \\
\text { RETURN-STATIC } \\
\text { RETURN-EFF } \\
\text { RETURN-DELTA-T } \\
\text { RETURN-KW } \\
\text { NIGHT-CYCLE-CTRL } \\
\text { FAN-EIR-FPLR }\end{array}$ & $\begin{array}{l}\text { From SUPPLY-DELTA-T \& SUPPLY-KW } \\
\text { From SUPPLY-DELTA-T \& SUPPLY-KW } \\
2.117^{\circ} \mathrm{F} \\
0.000685 \mathrm{~kW} / \mathrm{cfm} \\
\text { Always on } \\
\text { CONSTANT-VOLUME } \\
\text { From SUPPLY-EFF } \\
\text { IN-AIRFLOW } \\
1.1 \\
0.3 \\
\text { No return fan is simulated if neither pair } \\
\text { (RETURN-STATIC, RETURN-EFF) } \\
\text { or (RETURN-DELTA-T, RETURN-KW) } \\
\text { is Specified. } \\
\text { STAY-OFF } \\
\text { (only if FAN-CONTROL=FAN-EIR-FPLR) }\end{array}$ \\
\hline SYSTEM-TERMINAL & MIN-CFM-RATIO & Constant volume system \\
\hline & & Continued on next page. \\
\hline
\end{tabular}

$\bullet=$ Required keyword

- 99 -

- = Added/changed in 2.1E 
Continuation of

PMZS-System Type: Packaged Multi-Zone System

\begin{tabular}{|c|c|c|}
\hline Command & Keyword & Default Value or Consequence \\
\hline SYSTEM-EQUIPMENT & $\begin{array}{l}\text { See page } 36 \\
\text { CONDENSER-TYPE }\end{array}$ & - Air-cooled \\
\hline SYSTEM & $\begin{array}{l}\text { SYSTEM-TYPE=PMZS } \\
\text { ZONE-NAMES } \\
\text { SYSTEM-CONTROL } \\
\text { SYSTEM-AIR } \\
\text { SYSTEM-FANS } \\
\text { SYSTEM-TERMINAL } \\
\text { SYSTEM-EQUIPMENT } \\
\text { HEAT-SOURCE } \\
\text { BASEBOARD-SOURCE } \\
\text { HUMIDIFIER-TYPE } \\
\text { SIZING-RATIO } \\
\text { SIZING-OPTION } \\
\text { RETURN-AIR-PATH } \\
\text { EVAP-PCC-EFF } \\
\text { EVAP-PCC-SCH } \\
\text { PLENUM-NAMES }\end{array}$ & $\begin{array}{l}\bullet \\
\S \\
\S \\
\S \\
\S \\
\S \\
\text { GAS-FURNACE } \\
\text { ELECTRIC } \\
\text { ELECTRIC } \\
1.0 \\
\text { NON-COINCIDENT } \\
\text { DUCT } \\
8 \\
\text { (see u-name) } \\
\text { No return air plenum }\end{array}$ \\
\hline PLANT-ASSIGNMENT & See page 43 & \\
\hline$\S$ Any keyword from this sub & be placed in the SYSTEM cor & \\
\hline
\end{tabular}

In addition to the keywords listed above, all keywords that apply to

Night Ventilation (SYSTEM-FANS command)

Add-On Evaporative Cooling (SYSTEM-EQUIPMENT command)

Add-On (Integrated) Desiccant Cooling (SYSTEM command)

Service Hot Water Heat Pump (SYSTEM and PLANT-ASSIGNMENT commands)

Electric and Fuel Meters (SYSTEM, ZONE, and PLANT-ASSIGNMENT commands)

Building Resources (PLANT-ASSIGNMENT commands)

apply to this system. 


\begin{tabular}{|c|c|c|}
\hline \multicolumn{3}{|c|}{ PVAVS-System Type: Packaged Variable Air Volume System } \\
\hline Command & Keyword & Default Value or Consequence \\
\hline $\begin{array}{l}\text { ZONE-level } \\
\text { commands }\end{array}$ & See pages 63,88 & \\
\hline SYSTEM-CONTROL & $\begin{array}{l}\text { MAX-SUPPLY-T } \\
\text { MIN-SUPPLY-T } \\
\text { HEATING-SCHEDULE } \\
\text { COOLING-SCHEDULE } \\
\text { HEAT-SET-T } \\
\text { COOL-CONTROL } \\
\text { COOL-SET-T } \\
\text { COOL-RESET-SCH } \\
\text { COOL-SET-SCH } \\
\text { MAX-HUMIDITY } \\
\text { MIN-HUMIDITY } \\
\text { ECONO-LIMIT-T } \\
\text { ECONO-LOCKOUT } \\
\text { ECONO-LOW-LIMIT } \\
\text { WS-ECONO } \\
\text { WS-ECONO-MIN-DT } \\
\text { BASEBOARD-SCH } \\
\end{array}$ & $\begin{array}{l}\text { MIN-SUPPLY-T + REHEAT-DELTA-T } \\
\text { Always available } \\
\text { Always available } \\
\text { No main heating coil capacity } \\
\text { CONSTANT } \\
\text { MIN-SUPPLY-T } \\
\text { (only if COOL-CONTROL=RESET) } \\
\text { (only if COOL-CONTROL=SCHEDULED) } \\
\text { No dehumidification control } \\
\text { No humidification } \\
\text { Return air temperature } \\
\text { NO - Compressor runs w/OA dampers open } \\
\text { No lower limit } \\
\text { NO } \\
5.0^{\circ} \mathrm{F} \\
\text { Always off }\end{array}$ \\
\hline SYSTEM-AIR & $\begin{array}{l}\text { SUPPLY-CFM } \\
\text { RETURN-CFM } \\
\text { MIN-OUTSIDE-AIR } \\
\text { MIN-AIR-SCH } \\
\text { OA-CONTROL } \\
\text { MAX-OA-FRACTION } \\
\text { RECOVERY-EFF } \\
\text { DUCT-AIR-LOSS } \\
\text { DUCT-DELTA-T } \\
\end{array}$ & $\begin{array}{l}\text { From ZONE-AIR or load } / 1.08 \times \Delta T \\
\text { SUPPLY-CFM minus EXHAUST-CFM or } 0 \\
\text { From ZONE-AIR or none } \\
\text { No scheduling of outside air } \\
\text { TEMP } \\
1.0 \\
\text { No heat recovery simulated } \\
\text { None } \\
\text { None }\end{array}$ \\
\hline \multirow[t]{4}{*}{ SYSTEM-FANS } & $\begin{array}{l}\text { SUPPLY-STATIC } \\
\text { SUPPLY-EFF } \\
\text { SUPPLY-DELTA-T } \\
\text { SUPPLY-IKW }\end{array}$ & $\begin{array}{l}\text { From SUPPLY-DELTA-T \& SUPPLY-KW } \\
\text { From SUPPLY-DELTA-T \& SUPPLY-KW } \\
2.117^{\circ} \mathrm{F} \\
0.000685 \mathrm{~kW} / \mathrm{cm}\end{array}$ \\
\hline & $\begin{array}{l}\text { FAN-SCHEDULE } \\
\text { FAN-CONTROL } \\
\text { SUPPLY-MECH-EFF } \\
\text { MOTOR-PLACEMENT } \\
\text { FAN-PLACEMENT } \\
\text { MAX-FAN-RATIO } \\
\text { MIN-FAN-RATIO }\end{array}$ & $\begin{array}{l}\text { Always on } \\
\text { INLET } \\
\text { From SUPPLY-EFF } \\
\text { IN-AIRFLOW } \\
\text { DRAW-THROUGH } \\
1.1 \\
0.3\end{array}$ \\
\hline & $\begin{array}{l}\text { RETURN-STATIC } \\
\text { RETURN-EFF } \\
\text { RETURN-DELTA-T } \\
\text { RETURN-KW }\end{array}$ & $\begin{array}{l}\text { No return fan is simulated if neither pair } \\
\text { (RETURN-STATIC, RETURN-EFF) } \\
\text { or (RETURN-DELTA-T, RETURN-KW) } \\
\text { is specified. }\end{array}$ \\
\hline & $\begin{array}{l}\text { NIGHT-CYCLE-CTRL } \\
\text { FAN-EIR-FPLR } \\
\text { INDOOR-FAN-MODE }\end{array}$ & $\begin{array}{l}\text { STAY-OFF } \\
\text { (only if FAN-CONTROL=FAN-EIR-FPLR) } \\
\text { Continuous }\end{array}$ \\
\hline SYSTEM-TERMINAL & $\begin{array}{l}\text { REHEAT-DELTA-T } \\
\text { MIN-CFM-RATIO }\end{array}$ & $\begin{array}{l}\text { No reheat simulated } \\
\text { From outside air or heating load }\end{array}$ \\
\hline \multirow[t]{2}{*}{ SYSTEM-EQUIPMENT } & $\begin{array}{l}\text { CONDENSER-TYPE } \\
\text { WS-ECONO-XEFF }\end{array}$ & $\begin{array}{l}\text { Air-cooled } \\
0.6\end{array}$ \\
\hline & & Continued on next page. \\
\hline
\end{tabular}




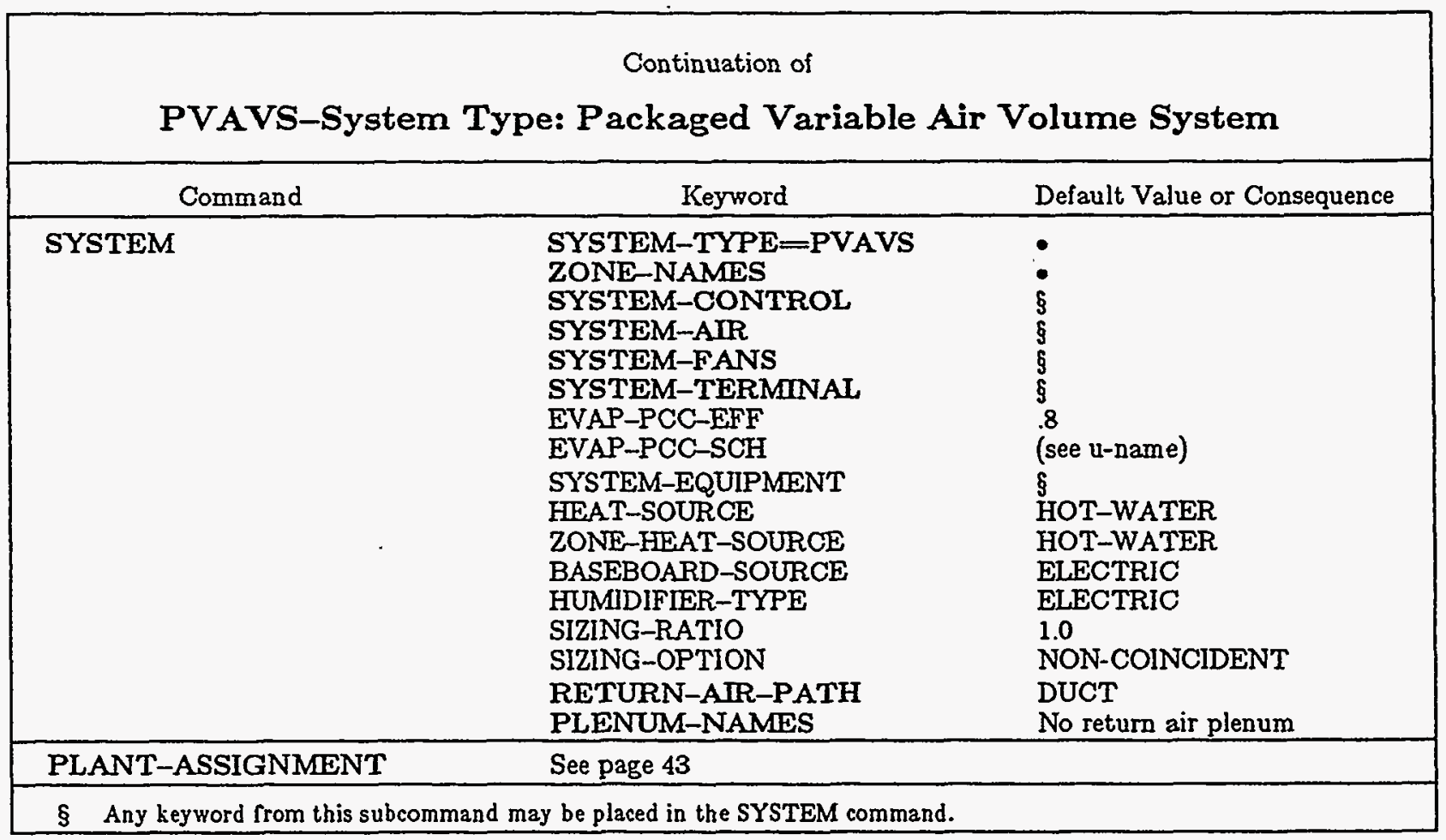

In addition to the keywords listed above, all keywords that apply to

Gas Heat Pump

Night Ventilation (SYSTEM-FANS command)

Add-On Evaporative Cooling (SYSTEM-EQUIPMENT command)

Add-On (Integrated) Desiccant Cooling (SYSTEM command)

Service Hot Water Heat Pump (SYSTEM and PLANT-ASSIGNMENT commands)

Electric and Fuel Meters (SYSTEM, ZONE, and PLANT-ASSIGNMENT commands)

Building Resources (PLANT-ASSIGNMENT commands)

apply to this system.

For water cooled condensers that apply to PVAVS, see the PLANT-ASSIGNMENT keywords that control the size of both tower and circulating pumps; see SYSTEM-FLUID for condenser flow variables. 


\begin{tabular}{|c|c|c|}
\hline \multicolumn{3}{|c|}{ PTAC-System Type: Packaged Terminal Air Conditioner System } \\
\hline Command & Keyword & Default Value or Consequence \\
\hline $\begin{array}{l}\text { ZONE-level } \\
\text { commands }\end{array}$ & See pages 63,88 & $\begin{array}{l}\text { (Input HEATING and COOLING } \\
\text { capacity when known) }\end{array}$ \\
\hline SYSTEM-CONTROL & $\begin{array}{l}\text { MAX-SUPPLY-T } \\
\text { MIN-SUPPLY-T } \\
\text { HEATING-SCHEDULE } \\
\text { COOLING-SCHEDULE } \\
\text { BASEBOARD-SCH }\end{array}$ & $\begin{array}{l}105^{\circ} \mathrm{F} \\
55^{\circ} \mathrm{F} \\
\text { Always available } \\
\text { Always available } \\
\text { Always off }\end{array}$ \\
\hline SYSTEM-AIR & $\begin{array}{l}\text { SUPPLY-CFM } \\
\text { MIN-OUTSIDE-AIR } \\
\text { MIN-AIR-SCH }\end{array}$ & $\begin{array}{l}\text { From loads or capacities } \\
\text { From ZONE-AIR or none } \\
\text { No scheduling of outside air }\end{array}$ \\
\hline SYSTEM-FANS & $\begin{array}{l}\text { SUPPLY-STATIC } \\
\text { SUPPLY-EFF } \\
\text { SUPPLY-DELTA-T } \\
\text { SUPPLY-KW } \\
\text { FAN-SCHEDULE } \\
\text { FAN-CONTROL } \\
\text { NIGHT-CYCLE-CTRL } \\
\text { LOW-SPEED-RATIOS } \\
\end{array}$ & $\begin{array}{l}\text { From SUPPLY-DELTA-T \& SUPPLY-KW } \\
\text { From SUPPLY-DELTA-T \& SUPPLY-KW } \\
0.218^{\circ} \mathrm{F} \\
0.00007 \mathrm{~kW} / \mathrm{cm} \\
\text { Always on } \\
\text { TWO-SPEED } \\
\text { STAY-OFF } \\
(1.0,1.0,1.0,1.0)\end{array}$ \\
\hline SYSTEM-EQUIPMENT & $\begin{array}{l}\text { COOLING-CAPACITY } \\
\text { COOL-CAP-FT } \\
\text { COOLING-EIR } \\
\text { COOL-EIR-FT } \\
\text { COOI-EIR-FPLR } \\
\text { COOL-SH-CAP } \\
\text { COOL-SH-FT } \\
\text { COIL-BF } \\
\text { COIL-BF-FCFM } \\
\text { COIL-BF-FT } \\
\text { COIL-BF-FPLR } \\
\text { MIN-SUPPLY-SCH } \\
\text { CONDENSER-TYPE } \\
\text { COOL-FT-MIN } \\
\text { RATED-CCAP-FCFM } \\
\text { RATED-SH-FCFM } \\
\text { RATED-CEIR-FCFM } \\
\text { RATED-HCAP-FCFM } \\
\text { RATED-HEIR-FCFM } \\
\text { HEATING-CAPACITY } \\
\text { HEAT-CAP-FT } \\
\text { HEATING-EIR } \\
\text { HEAT-EIR-FT } \\
\text { HEAT-EIR-FPLR } \\
\text { HP-SUPP-HT-CAP } \\
\text { CRANKCASE-HEAT } \\
\text { CRANIKCASE-MAX-T } \\
\text { MIN-HP-T } \\
\text { MAX-HP-SUPP-T } \\
\text { HP-SUPP-SOURCE }\end{array}$ & $\begin{array}{l}\text { Dependent on peak loads } \\
\text { Standard curve SDL-C2 } \\
0.438 \text { Btu/Btu } \\
\text { Standard curve SDL-C12 } \\
\text { Standard curve SDL-C17 } \\
\text { From loads } \\
\text { Standard curve SDL-C22 } \\
0.241 \\
\text { Standard curve SDL-C32 } \\
\text { Standard curve SDL-C42 } \\
\text { Standard curve SDL-C120 } \\
\text { uses MIN-SUPPLY-T } \\
\text { E Air-cooled } \\
70.0^{\circ} \text { F } \\
\text { Standard curve SDL-C77 } \\
\text { Standard curve SDL-C84 } \\
\text { Standard curve SDL-C92 } \\
\text { Standard curve SDL-C99 } \\
\text { Standard curve SDL-C106 } \\
\text { Dependent on peak loads } \\
\text { Standard curve SDL-C52 } \\
0.370 \text { Btu/Btu } \\
\text { Standard curve SDL-C57 } \\
\text { Standard curve SDL-C62 } \\
\text { From heating loads } \\
.025 \text { kW } \\
50^{\circ} \text { F } \\
40^{\circ} \text { F } \\
40.0^{\circ} \text { F } \\
\text { ELECTRIC }\end{array}$ \\
\hline & & Continued on next page. \\
\hline
\end{tabular}


Continuation of

PTAC-System Type: Packaged Terminal Air Conditioner System

\begin{tabular}{|c|c|c|}
\hline Command & Keyword & Default Value or Consequence \\
\hline SYSTEM-EQUIPMENT & $\begin{array}{l}\text { FURNACE-AUX } \\
\text { FURNACE-AUX-KW } \\
\text { FURNACE-HIR } \\
\text { FURNACE-HIR-FPLR } \\
\text { FURNACE-OFF-LOSS } \\
\text { EVAP-CL-TYPE } \\
\text { EVAP-CL-KW } \\
\text { EVAP-CL+REC-RA } \\
\text { DIRECT-EFF } \\
\text { INDIR-EFF }\end{array}$ & $\begin{array}{l}800.0 \mathrm{Btu} / \mathrm{hr} \\
0.0 \mathrm{~kW} \\
1.35 \mathrm{Btu} / \mathrm{Btu} \\
\text { Standard curve SDL-C111 } \\
\text { No loss accounted for } \\
\text { INDIRECT-DIRECT } \\
.0005 \mathrm{~kW} / \mathrm{cfm} \\
\text { NO (recirculation) } \\
.85 \\
.80\end{array}$ \\
\hline SYSTEM & $\begin{array}{l}\text { SYSTEM-TYPE=PTAC } \\
\text { ZONE-NAMES } \\
\text { SYSTEM-CONTROL } \\
\text { SYSTEM-AIR } \\
\text { SYSTEM-FANS } \\
\text { SYSTEM-EQUIPMENT } \\
\text { HEAT-SOURCE } \\
\text { EVAP-PCC-EFF } \\
\text { EVAP-PCC-SCH } \\
\text { BASEBOARD-SOURCE } \\
\text { SIZING-RATIO }\end{array}$ & $\begin{array}{l}\bullet \\
\S \\
\S \\
\S \\
\S \\
\text { ELECTRIC } \\
\text { (HEAT-PUMP is OPTION) } \\
.8 \\
\text { (see U-name) } \\
\text { ELECTRIC } \\
1.0\end{array}$ \\
\hline PLANT-ASSIGNMENT & See page 43 & \\
\hline
\end{tabular}

In addition to the keywords listed above, all keywords that apply to

Gas Heat Pump

Night Ventilation (SYSTEM-FANS command)

Add-On Evaporative Cooling (SYSTEM-EQUIPMENT command)

Add-On (Integrated) Desiccant Cooling (SYSTEM command)

Service Hot Water Heat Pump (SYSTEM and PLANT-ASSIGNMENT commands)

Electric and Fuel Meters (SYSTEM, ZONE, and PLANT-ASSIGNMENT commands)

Building Resources (PLANT-ASSIGNMENT commands)

apply to this system. 


\begin{tabular}{|c|c|c|}
\hline \multicolumn{3}{|c|}{ PTGSD-System Type: Packaged Total Gas Solid Desiccant } \\
\hline Command & Keyword & Derault Value or Consequence \\
\hline ZONE-CONTROL & $\begin{array}{l}\text { HEAT-TEMP-SCH } \\
\text { COOL-TEMP-SCH } \\
\text { THROTTLING-RANGE } \\
\text { BASEBOARD-CTRL } \\
\end{array}$ & $\begin{array}{l}\text { No active heating } \\
\text { No active heating } \\
2^{\circ} \mathrm{F} \\
\text { Outdoor-reset }\end{array}$ \\
\hline ZONE-AIR & $\begin{array}{l}\text { ASSIGNED-CFM } \\
\text { CFM-SQFT } \\
\text { AIR-CHANGES/HR } \\
\text { OUTSDE-AIR-CFM } \\
\text { OA-CFM/PER } \\
\text { OA-CHANGES } \\
\text { EXHAUST-CFM } \\
\text { EXHAUST-EFF } \\
\text { EXHAUST-STATIC } \\
\text { EXHAUST-KW } \\
\text { SS-VENT-SCH } \\
\text { SS-VENT-T-SCH } \\
\text { SS-VENT-CST } \\
\text { SS-VENT-WND } \\
\text { SS-VENT-TEMP } \\
\text { SS-VENT-LIMIT-T } \\
\text { SS-VENT-ISW } \\
\text { SS-FLOW-SCH }\end{array}$ & 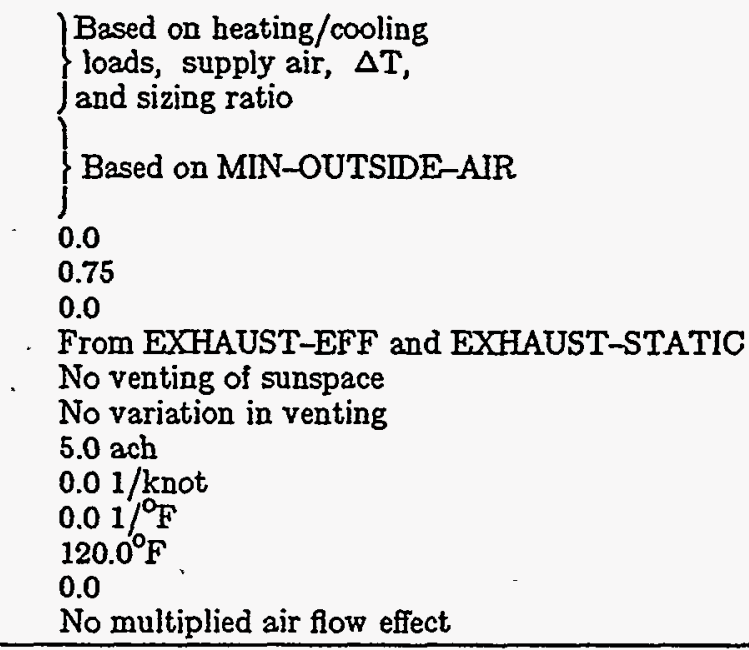 \\
\hline ZONE & $\begin{array}{l}\text { ZONE-CONTROL } \\
\text { ZONE-AIR } \\
\text { ZONE-TYPE } \\
\text { MULTIPLIER } \\
\text { FLOOR-MULTIPLIER } \\
\text { BASEBOARD-RATING } \\
\text { TROM-VENT-SCH }\end{array}$ & $\begin{array}{l}\S \\
\S \\
\text { CONDITIONED } \\
\text { Taken from SPACE in LOADS } \\
\text { Taken from SPACE in LOADS } \\
\text { No baseboard heating } \\
\text { - (only if TROMBE-WALL-V specified) }\end{array}$ \\
\hline SYSTEM-CONTROL & $\begin{array}{l}\text { HEATING-SCHEDULE } \\
\text { COOLING-SCHEDULE } \\
\text { MAX-HUMIDITY } \\
\text { BASEBOARD-SCH } \\
\end{array}$ & $\begin{array}{l}\text { Always available } \\
\text { Always available } \\
\text { No dehumidification control } \\
\text { Always of }\end{array}$ \\
\hline SYSTEM-AIR & $\begin{array}{l}\text { SUPPLY-CFM } \\
\text { MIN-OUTSIDE-AIR } \\
\text { DUCT-AIR-LOSS } \\
\text { DUCT-DELTA-T }\end{array}$ & $\begin{array}{l}\text { REQUIRED } \\
\text { From ZONE-AIR or none } \\
\text { None } \\
\text { None }\end{array}$ \\
\hline SYSTEM-FANS & $\begin{array}{l}\text { SUPPLY-STATIC } \\
\text { SUPPLY-EFF } \\
\text { SUPPLY-DELTA-T } \\
\text { SUPPLY-KW } \\
\text { FAN-SCHEDULE } \\
\text { FAN-CONTROL } \\
\text { SUPPLY-MECH-EFF } \\
\text { MOTOR-PLACEMENT } \\
\text { MIN-FAN-RATIO } \\
\text { MAX-FAN-RATIO } \\
\text { NIGHT-CYCLE-CTRL } \\
\text { FAN-EIR-FPIR } \\
\text { SYSTEM-TERMINAL } \\
\end{array}$ & $\begin{array}{l}\text { From SUPPLY-DELTA-T \& SUPPLY-KW } \\
\text { From SUPPLY-DELTA-T \& SUPPLY-KW } \\
1.2 \\
.0004 \\
\text { Always on } \\
\text { SPEED } \\
\text { From SUPPLY-EFF } \\
\text { IN-AIRFLOW } \\
.3 \\
1.1 \\
\text { STAY-OFF } \\
\text { - (only if FAN-CONTROL=FAN-EIR-FPLR) } \\
\text { MIN-CFM-RATIO .3 }\end{array}$ \\
\hline \multicolumn{3}{|c|}{$\S$ Any keyword from this subcommand may be placed in the zONE command. } \\
\hline & & Continued on next page. \\
\hline
\end{tabular}


Continuation of

PTGSD-System Type: Packaged Total Gas Solid Desiccant

\begin{tabular}{|c|c|c|}
\hline Command & Keyword & Default Value or Consequence \\
\hline SYSTEM-EQUIPMENT & HEATING-CAPACITY & Required \\
\hline SYSTEM-TERMINAL & MIN-CFM-RATIO & a.3 \\
\hline SYSTEM & $\begin{array}{l}\text { SYSTEM-TYPE=PTGSD } \\
\text { ZONE-NAMES } \\
\text { SYSTEM-CONTROL } \\
\text { SYSTEM-AIR } \\
\text { SYSTEM-FANS } \\
\text { SYSTEM-TERMINAL } \\
\text { SYSTEM-EQUIPMENT } \\
\text { HEAT-SOURCE } \\
\text { BASEBOARD-SOURCE } \\
\text { ZONE-HEAT-SOURCE } \\
\text { RETURN-AIR-PATH } \\
\text { PLENUM-NAMES } \\
\end{array}$ & $\begin{array}{l}\text { - (first listed must be control zone) } \\
\S \\
\S \\
\S \\
\S \\
\S \\
\text { GAS-HYDRONIC } \\
\text { GAS-HYDRONIC } \\
\text { GAS-HYDRONIC } \\
\text { DIRECT } \\
\text { No return air plenum } \\
\end{array}$ \\
\hline PLANT-ASSIGNMENT & See page 43 & \\
\hline
\end{tabular}

In addition to the keywords listed above, all keywords that apply to

Night Ventilation (SYSTEM-FANS command)

Add-On Evaporative Cooling (SYSTEM-EQUIPMENT command)

Add-On (Integrated) Desiccant Cooling (SYSTEM command)

Service Hot Water Heat Pump (SYSTEM and PLANT-ASSIGNMENT commands)

Electric and Fuel Meters (SYSTEM, ZONE, and PLANT-ASSIGNMENT commands)

Building Resources (PLANT-ASSIGNMENT commands)

apply to this system. 


\begin{tabular}{|c|c|c|}
\hline \multicolumn{3}{|c|}{$\begin{array}{c}\text { EVAP-COOL System Type: } \\
\text { Stand Alone Evaporative Cooling Unit }\end{array}$} \\
\hline Command & Keyword & Default Value or Consequence \\
\hline $\begin{array}{l}\text { ZONE-level } \\
\text { commands }\end{array}$ & \multicolumn{2}{|l|}{ See pages 63,88} \\
\hline SYSTEM-CONTROL & \multicolumn{2}{|c|}{$\begin{array}{ll}\text { MAX-SUPPLY-T } & \\
\text { MIN-SUPPLY-T } & \\
\text { HEATING-SCHEDULE } & \text { Always available } \\
\text { COOLING-SCHEDULE } & \text { Always available } \\
\text { ECONO-LIMTT-T } & 100^{\circ} \mathrm{F} \text { 口 } \\
\text { BASEBOARD-SCH } & \text { Always off } \\
\end{array}$} \\
\hline SYSTEM-AIR & $\begin{array}{l}\text { SUPPLY-CFM } \\
\text { MIN-OUTSIDE-AIR } \\
\text { DUCT-AIR-LOSS } \\
\text { DUCT-DELTA-T }\end{array}$ & $\begin{array}{l}\text { Must be precalculated by user } \\
\text { From ZONE-AIR or none during heating } \\
\text { None } \\
\text { None }\end{array}$ \\
\hline SYSTEM-FANS & $\begin{array}{l}\text { SUPPLY-STATIO } \\
\text { SUPPLY-EFF } \\
\text { SUPPLY-DELTA-T } \\
\text { SUPPLY-IWW } \\
\text { FAN-SCHEDULE } \\
\text { FAN-CONTROL } \\
\text { SUPPLY-MECH-EFF } \\
\text { MOTOR-PLACEMENT } \\
\text { FAN-PLACEMENT } \\
\text { MAX-FAN-RATIO } \\
\text { NIGHT-CYCLE-CTRL } \\
\text { FAN-EIR-FPLR } \\
\end{array}$ & $\begin{array}{l}\text { From SUPPLY-DELTA-T \& SUPPLY-KW } \\
\text { From SUPPLY-DELTA-T \& SUPPLY-KW } \\
2.42^{\circ} \mathrm{F} \\
0.000783 \mathrm{~kW} / \mathrm{cfm} \\
\text { Always On } \\
\text { CONSTANT-VOLUME } \\
\text { From SUPPLY-EFF } \\
\text { IN-AIRFLOW } \\
\text { DRAW-THROUGH } \\
\text { 1.1 } \\
\text { STAY-OFF } \\
\text { (only if FAN-CONTROL=FAN-EIR-FPLR) }\end{array}$ \\
\hline SYSTEM-EQUIPMENT & $\begin{array}{l}\text { EVAP-CL-TYPE } \\
\text { EVAP-CL-KW } \\
\text { EVAP-CL+REC-RA } \\
\text { DIRECT-EFF } \\
\text { INDIR-EFF }\end{array}$ & $\begin{array}{l}\text { INDIRECT-DIRECT } \\
.0005 \mathrm{~kW} / \mathrm{cfm} \\
\mathrm{NO} \text { (recirculation) } \\
.85 \\
.80\end{array}$ \\
\hline SYSTEM & $\begin{array}{l}\text { SYSTEM-TYPE=EVAF } \\
\text { ZONE-NAMES } \\
\text { SYSTEM-CONTROL } \\
\text { SYSTEM-AIR } \\
\text { SYSTEM-FANS } \\
\text { SYSTEM-EQUIPMENT } \\
\text { HEAT-SOURCE } \\
\text { ZONE-HEAT-SOURCE } \\
\text { BASEBOARD-SOURCE } \\
\text { SIZING-RATIO } \\
\text { SIZING-OPTION } \\
\text { RETURN-AIR-PATH } \\
\text { PLENUM-NAMES } \\
\end{array}$ & $\begin{array}{l}\bullet \text { (First listed must be control zone) } \\
\S \\
\S \\
\S \\
\S \\
\text { HOT-WATER } \\
\text { HOT-WATER } \\
\text { HOT-WATER } \\
1.0 \\
\text { NON-COINCIDENT } \\
\text { DIRECT } \\
\text { NO return air plenum } \\
\end{array}$ \\
\hline PLANT-ASSIGNMENT & \multicolumn{2}{|l|}{ See page 43} \\
\hline
\end{tabular}

In addition to the keywords listed above, all keywords that apply to the following also apply to this system.

Night Ventilation (SYSTEM-FANS command)

Service Hot Water Heat Pump (SYSTEM and PLANT-ASSIGNMENT commands)

Electric and Fuel Meters (SYSTEM, ZONE, and PLANT-ASSIGNMENT commands)

Building Resources (PLANT-ASSIGNMENT commands) 


\section{PVVT-System Type:}

Packaged Single Zone Fan System - Variable Volume - Variable Temperature

\begin{tabular}{|c|c|c|}
\hline Command & Keyword & Default Value or Consequence \\
\hline ZONE-level & See pages 63,88 & \\
\hline SYSTEM-CONTROL & $\begin{array}{l}\text { MAX-SUPPLY-T } \\
\text { MIN-SUPPLY-T } \\
\text { HEATING-SCHEDULE } \\
\text { COOLING-SCHEDULE } \\
\text { MAXIMUM-HUMIDITY } \\
\text { MINIMUM-HUMDITY } \\
\text { DRYBULB-LIMIT } \\
\text { BASEBOARD-SCH }\end{array}$ & $\begin{array}{l}105^{\circ} \mathrm{F} \\
55^{\circ} \mathrm{F} \\
\text { Always available } \\
\text { Always available } \\
\text { No dehumidification control } \\
\text { No humidification } \\
\text { Return air temperature } \\
\text { Always off }\end{array}$ \\
\hline SYSTEM-AIR & $\begin{array}{l}\text { SUPPLY-CFM } \\
\text { RETURN-AIR } \\
\text { MN-OUTSIDE-AIR } \\
\text { MIN-AIR-SCH } \\
\text { OA-CONTROL } \\
\text { MAX-OA-FRACTION } \\
\text { DUCT-AIR-LOSS } \\
\text { DUCT-DELTA-T } \\
\text { VENT-TEMP-SCH }\end{array}$ & $\begin{array}{l}\text { From ZONE-AIR or load/1.08*DT } \\
\text { SUPPLY-CFM minus EXHAUST-CFM or } 0.0 \\
\text { From ZONE-AIR or none } \\
\text { No scheduling of outside air } \\
\text { TEMP } \\
1.0 \\
\text { None } \\
\text { None } \\
\text { HEAT-TEMP-SCH + } \\
.5 * \text { THROTTLING-RANGE } \\
\end{array}$ \\
\hline SYSTEM-FANS & $\begin{array}{l}\text { SUPPLY-STATIC } \\
\text { SUPPLY-EFF } \\
\text { SUPPLY-DELTA-T } \\
\text { SUPPLY-KW } \\
\text { FAN-SCHEDULE } \\
\text { SUPPLY-MECH-EFF } \\
\text { MOTOR-PLACEMENT } \\
\text { FAN-PLACEMENT } \\
\text { MAX-FAN-RATIO } \\
\text { MIN-FAN-RATIO } \\
\text { INDOOR-FAN-MODE } \\
\text { NGHT-CYCLE-CTRL }\end{array}$ & $\begin{array}{l}\text { None } \\
\text { None } \\
2.117 \\
.0007 \\
\text { Always on } \\
\text { From SUPPLY-STATIC } \\
\text { IN-AIRFLOW } \\
\text { DRAW-THROUGH } \\
1.0 \\
0.3 \\
\text { Continuous } \\
\text { STAY-OFF } \\
\end{array}$ \\
\hline SYSTEM-EQUIPMENT & $\begin{array}{l}\text { COMPRESSOR-TYPE } \\
\text { CONDENSER-TYPE } \\
\text { HP-SUPP-SOURCE } \\
\text { DEFROST-TYPE } \\
\text { DEFROST-CTRL }\end{array}$ & $\begin{array}{l}\text { VARLABLE-SPEED } \\
\text { AIR-COOLED } \\
\text { ELECTRIC } \\
\text { RESISTIVE } \\
\text { TIMED } \\
\end{array}$ \\
\hline word & nd may be placed in the $Z$ & nand. \\
\hline
\end{tabular}




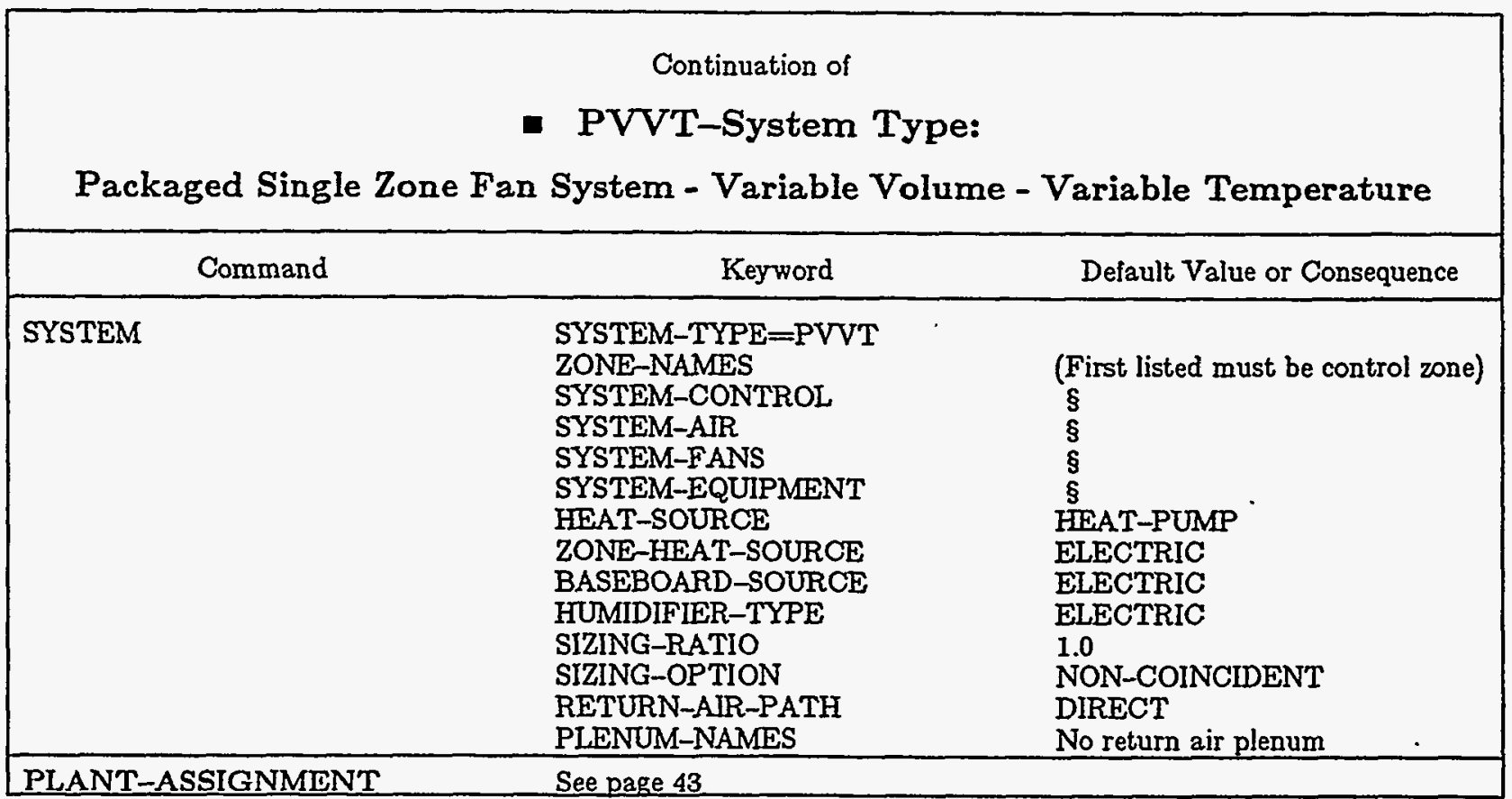

In addition to the keywords listed above, all keywords that apply to

Night Ventilation (SYSTEM-FANS command)

Add-On Evaporative Cooling (SYSTEM-EQUIPMENT command)

Add-On (Integrated) Desiccant Cooling (SYSTEM command)

Service Hot Water Heat Pump (SYSTEM and PLANT-ASSIGNMENT commands)

Electric and Fuel Meters (SYSTEM, ZONE, and PLANT-ASSIGNMENT commands)

Building Resources (PLANT-ASSIGNMENT commands)

Gas Heat Pumps

apply to this system. 


\begin{tabular}{|c|c|c|}
\hline \multicolumn{3}{|c|}{ Single Zone Fan System - Variable Volume - Variable Temperature } \\
\hline Command & Keyword & Default Value or Consequence \\
\hline ZONE-level & See pages 63,88 & \\
\hline SYSTEM-CONTROL & $\begin{array}{l}\text { MAX-SUPPLY-T } \\
\text { MIN-SUPPLY-T } \\
\text { HEATING-SCHEDULE } \\
\text { COOLING-SCHEDULE } \\
\text { MAXIMUM-HUMIDITY } \\
\text { MINIMUM-HUMIDITY } \\
\text { BASEBOARD-SCH } \\
\end{array}$ & $\begin{array}{l}105^{\circ} \mathrm{F} \\
55^{\circ} \mathrm{F} \\
\text { Always available } \\
\text { Always available } \\
\text { No dehumidification control } \\
\text { No humidification } \\
\text { Always off } \\
\end{array}$ \\
\hline SYSTEM-AIR & $\begin{array}{l}\text { SUPPLY-CFM } \\
\text { DUCT-AIR-LOSS } \\
\text { DUCT-DELTA-T }\end{array}$ & $\begin{array}{l}\text { From ZONE-AIR or load } / 1.08 * \mathrm{DT} \\
\text { None } \\
\text { None }\end{array}$ \\
\hline SYSTEM-FANS & $\begin{array}{l}\text { SUPPLY-STATIC } \\
\text { SUPPLY-EFF } \\
\text { SUPPLY-DELTA-T } \\
\text { SUPPLY-IWW } \\
\text { FAN-SCHEDULE } \\
\text { FAN-CONTROL } \\
\text { SUPPLY-MECH-EFF } \\
\text { MOTOR-PLACEMENT } \\
\text { FAN-PLACEMENT } \\
\text { MAX-FAN-RATIO } \\
\text { MIN-FAN-RATIO } \\
\end{array}$ & $\begin{array}{l}\text { None } \\
\text { None } \\
0.4 \\
.00016 \\
\text { Always on } \\
\text { Speed } \\
\text { From SUPPLY-STATIC } \\
\text { IN-AIRFLOW } \\
\text { DRAW-THROUGH } \\
1.0 \\
0.3 \\
\end{array}$ \\
\hline SYSTEM & $\begin{array}{l}\text { SYSTEM-TYPE=RESVVT } \\
\text { ZONE-NAMES } \\
\text { SYSTEM-CONTROL } \\
\text { SYSTEM-AIR } \\
\text { SYSTEM-FANS } \\
\text { SYSTEM-EQUIPMENT } \\
\text { HEAT-SOURCE } \\
\text { ZONE-HEAT-SOURCE } \\
\text { BASEBOARD-SOURCE } \\
\text { HUMIDIFIER-TYPE } \\
\text { SIZING-RATIO } \\
\text { SIZING-OPTION }\end{array}$ & $\begin{array}{l}\S \\
\S \\
\S \\
\S \\
\text { HEAT-PUMP } \\
\text { ELECTRIC } \\
\text { ELECTRIC } \\
\text { ELECTRIC } \\
1.0 \\
\text { NON-COINCIDENT }\end{array}$ \\
\hline & & Continued on next page. \\
\hline
\end{tabular}


Continuation of

- RESVVT-System Type:

Single Zone Fan System - Variable Volume - Variable Temperature

\begin{tabular}{|c|c|c|}
\hline Command & Keyword & Default Value or Consequence \\
\hline \multirow[t]{39}{*}{ SYSTEM-EQUIPMENT } & MIN-HP-T & $10^{\circ} \mathrm{F}$ \\
\hline & MAX-HP-SUPP-T & $40^{\circ} \mathrm{F}$ \\
\hline & HP-SUPP-SOURCE & Electric \\
\hline & COOLING-CAPACITY & $\begin{array}{l}\text { from peak loads } \\
\text { (user should enter a value) }\end{array}$ \\
\hline & COOL-SH-CAP & $\begin{array}{l}\text { from peak loads } \\
\text { (user should enter a value) }\end{array}$ \\
\hline & COOLING-EIR & .343 \\
\hline & COOL_CAP-FT & Standard curve SDL-C4 \\
\hline & COOL-SH-FT & Standard curve SDL-C24 \\
\hline & COOL-CAP-FRPM & Standard curve SDL-C151 \\
\hline & COOL-EIR-FT & Standard curve SDL-C82 \\
\hline & $\begin{array}{l}\text { COOL-EIR-LS-FT } \\
\text { COOL-RPM-LIMITS }\end{array}$ & $\begin{array}{l}\text { Standard curve SDL-C132 } \\
3500,1000 \mathrm{rpm}\end{array}$ \\
\hline & COIL-BF & .14 \\
\hline & COIL-BF-FCFM & Standard curve SDL-C34 \\
\hline & COIL-BF-FT & Standard curve SDL-C44 \\
\hline & COIL-BF-FPLR & Standard curve SDL-C131 \\
\hline & COOL-FT-MIN & $70^{\circ} \mathrm{F}$ \\
\hline & COOL-CTRL-RANGE & $4^{\circ} \mathrm{F}$ \\
\hline & COOL-CLOSS-FPLR & Standard curve SDL-C147 \\
\hline & COOL-CLOSS-MIN & 0.8 \\
\hline & HEATING-CAPACITY & from peak loads \\
\hline & HEATING-EIR & .306 \\
\hline & HEAT-CAP-FT & Standard curve SDL-C95 \\
\hline & HEAT-CAP-FRPM & Standard curve SDL-C152 \\
\hline & HEAT-EIR-FT & Standard curve SDL-C104 \\
\hline & HEAT-EIR-LS-FT & Standard curve SDL-C133 \\
\hline & HEAT-RPM-LIMITS & $3500,1000 \mathrm{rpm}$ \\
\hline & HEAT-GLOSS-FPLR & Standard curve SDL-C146 \\
\hline & HEAT-CLOSS-MIN & 0.8 \\
\hline & HP-SUPP-HT-CAP & from peak loads \\
\hline & FURNACE-AUX & $800 \mathrm{btu} / \mathrm{hr}$ \\
\hline & FURNACE-HIR & 1.35 \\
\hline & FURNACE-HIR-FPLR & Standard curve SDL-C111 \\
\hline & FURNACE-OFF-LOSS & 0. \\
\hline & FURNACE-AUX-KW & 0. \\
\hline & CRANKCASE-HEAT & $.05 \mathrm{~kW}$ \\
\hline & CRANIKCASE-MAX-T & $50^{\circ} \mathrm{F}$ \\
\hline & COMPRESSION-TYPE & variable-speed \\
\hline & OUTSIDE-FAN-ELEC & no explicit elec \\
\hline & OUTSIDE-FAN-T & user must enter value \\
\hline & & Continued on next page. \\
\hline
\end{tabular}

- = Required keyword 
Continuation of

\section{- RESVVT-System Type:}

Single Zone Fan System - Variable Volume - Variable Temperature

\begin{tabular}{|c|c|c|}
\hline Command & Keyword & Default Value or Consequence \\
\hline \multirow[t]{23}{*}{ SYSTEM-EQUIPMENT } & OUTSIDE-FAN-MODE & intermittent \\
\hline & OUTSIDE-FAN-CFLT & Standard curve SDL-C139 \\
\hline & OUTSIDE-FAN-HFLT & Standard curve SDL-C145 \\
\hline & DEFROST-TYPE & reverse cycle \\
\hline & DEFROST-CTRL & on-demand \\
\hline & DEFROST-FRAC-FT & Standard curve SDL-C188 \\
\hline & DEFROST-T & $40^{\circ} \mathrm{F}$ \\
\hline & COOL-WASTE-HEAT & 0.23 \\
\hline & HEAT-WASTE-HEAT & 0.25 \\
\hline & WASTE-HEAT-USE & space-heat \\
\hline & COOL-WH-FT & Standard curve SDL-C136 \\
\hline & COOL-WH-FRPM & Standard curve SDL-C137 \\
\hline & HEAT-WH-FT & Standard curve SDL-C142 \\
\hline & HEAT-WH-FRPM & Standard curve SDL-C143 \\
\hline & CONDENSER-TYPE & air-cooled \\
\hline & EVAP-PCC-ELEC & .0017 watts $/$ btu \\
\hline & EVAP-PCC-EFF & 0.8 \\
\hline & EVAP-PCC-SCH & see Supplement (2.1E) \\
\hline & RATED-CCAP-FCFM & Standard curve SDL C78 \\
\hline & RATED-SH-FCFM & Standard curve SDL-C85 \\
\hline & RATED-CEIR-FCFM & Standard curve SDL-C93 \\
\hline & RATED-HCAP-FCFM & Standard curve SDL C100 \\
\hline & RATED-HEIR-FCFM & Standard curve SDL-C105 \\
\hline PLANT-ASSIGNMENT & See page 43 & \\
\hline
\end{tabular}

In addition to the keywords listed above, all keywords that apply to the following also apply to this system.

Night Ventilation (SYSTEM-FANS)

Add-On Evaporative Cooling (SYSTEM-EQUIPMENT)

Add-On (Integrated) Desiccant Cooling (SYSTEM)

Service Hot Water Heat Pump (SYSTEM and PLANT-ASSIGNMENT)

Electric and Fuel Meters (SYSTEM, ZONE, and PLANT-ASSIGNMENT)

and Building Resources (PLANT-ASSIGNMENT) 


\begin{tabular}{|c|c|c|}
\hline \multicolumn{3}{|c|}{ SUM-System Type } \\
\hline Command & Keyword & Default Value or Consequence \\
\hline ZONE-CONTROL & $\begin{array}{l}\text { DESIGN-HEAT-T } \\
\text { HEAT-TEMP-SCH } \\
\text { DESIGN-COOL-T } \\
\text { COOL-TEMP-SCH } \\
\text { THERMOSTAT-TYPE } \\
\text { THROTTLING-RANGE }\end{array}$ & $\begin{array}{l}70^{\circ} \mathrm{F} \\
76^{\circ} \mathrm{F} \\
\bullet \\
\text { PROPORTIONAL } \\
2{ }^{\circ} \mathrm{F}\end{array}$ \\
\hline ZONE & $\begin{array}{l}\text { ZONE-CONTROL } \\
\text { ZONE-TYPE } \\
\text { MULTIPLIER } \\
\text { FLOOR-MULTIPLIER } \\
\text { MAX-HEAT-RATE } \\
\text { MAX-COOL-RATE } \\
\text { SIZING-OPTION }\end{array}$ & $\begin{array}{l}\$ \\
\text { CONDITIONED } \\
\text { Taken from SPACE in LOADS } \\
\text { Taken from SPACE in LOADS } \\
\text { Peak load } \\
\text { Peak load } \\
\text { FROM-LOADS }\end{array}$ \\
\hline SYSTEM-CONTROL & $\begin{array}{l}\text { HEATING-SCHEDULE } \\
\text { COOLING-SCHEDULE }\end{array}$ & $\begin{array}{l}\text { Always available } \\
\text { Always available }\end{array}$ \\
\hline SYSTEM-FANS & $\begin{array}{l}\text { FAN-SCHEDULE } \\
\text { NIGHT-CYCLE-CTRL }\end{array}$ & $\begin{array}{l}\text { Always on } \\
\text { STAY-OFF }\end{array}$ \\
\hline SYSTEM & $\begin{array}{l}\text { SYSTEM-TYPE=SUM } \\
\text { ZONE-NAMES } \\
\text { SYSTEM-CONTROL } \\
\text { SYSTEM-FANS } \\
\text { SIZING-RATIO }\end{array}$ & $\begin{array}{l}\bullet \\
\vdots \\
\S \\
1.0\end{array}$ \\
\hline PLANT-ASSIGNMENT & See page 43 & \\
\hline word from thi & may be placed in & \\
\hline
\end{tabular}

\section{FNSYS1-System Type}

FNSYS1 is for use with SYSTEMS Functions. It is identical to the system type SUM, except that it has all of the SYSTEM keywords enabled. By using the FNSYS1-1, FNSYS1-2Z, FNSYS1-3Z, FNSYS1-4Z, FNSYS1-5 keywords of the SUBR-FUNCTIONS command (p. 29) you can change the computation algorithm of the basic FNSYS1 system and thereby build a custom system type. 
SYSTEM TYPES

\begin{tabular}{|c|c|c|}
\hline \multicolumn{3}{|c|}{$\begin{array}{l}\text { SYSTEM-EQUTPMENT keywords } \\
\text { For Central Systems } \\
\text { H, MZS, DDS, SZC, TPIU, FPIU, VAVS, PIU, RHFS, and CBVAV }\end{array}$} \\
\hline Command & Keyword & Default Value or Consequence \\
\hline SYSTEM-EQUIPMENT & $\begin{array}{l}\text { COOLING-CAPACITY } \\
\text { COOL-CAP-FT } \\
\text { COOL-SH-CAP } \\
\text { COOL-SH-FT } \\
\text { COIL-BF } \\
\text { COIL-BF-FCFM } \\
\text { COIL-BF-FT } \\
\text { COIL-BF-FPLR } \\
\text { MIN-SUPPLY-SCH } \\
\text { COOI-CTRL-RANGE } \\
\text { COOL-FT-MIN } \\
\text { HEATING-CAPACITY } \\
\text { HCOIL-WIPE-FCFM } \\
\text { FURNACE-AUX } \\
\text { FURNACE-AUX-KW } \\
\text { FURNACE-HIR } \\
\text { FURNACE-HIR-FPLR } \\
\text { FURNACE-OFF-LOSS }\end{array}$ & $\begin{array}{l}\text { Dependent on peak loads } \\
\text { Standard curve SDI-C7 } \\
\text { From loads } \\
\text { Standard curve SDL-C27 } \\
\text { 0.037 (0.078 for MZS) } \\
\text { Standard curve SDI-C38 } \\
\text { Standard curve SDL-C48 } \\
\text { Standard curve SDL-C161 } \\
\text { uses MIN-SUPPLY-T } \\
4.0^{\circ} \mathrm{F} \\
70.0^{\circ} \mathrm{F} \\
\text { Dependent on peak loads } \\
\text { No effect (Used only for MZS and DDS) } \\
800.0 \mathrm{Btu} / \mathrm{hr} \\
0.0 \mathrm{~kW} \\
1.35 \text { Btu/Btu } \\
\text { Standard curve SDL-C111 } \\
\text { No loss accounted for }\end{array}$ \\
\hline
\end{tabular}

\begin{tabular}{|c|c|c|}
\hline \multicolumn{3}{|c|}{$\begin{array}{c}\text { SYSTEM-EQUIPMENT keywords } \\
\text { For Zonal Systems } \\
\text { System Types TPFC and FPFC }\end{array}$} \\
\hline Command & Keyword & Default Value or Consequence \\
\hline SYSTEM-EQUIPMENT & $\begin{array}{l}\text { COOLING-CAPACITY } \\
\text { COOL-CAP-FT } \\
\text { COOL-SH-CAP } \\
\text { COOL-SH-FT } \\
\text { COIL-BF } \\
\text { COIL-BF-FCFM } \\
\text { COIL-BF-FT } \\
\text { COIL-BF-FPLR } \\
\text { MIN-SUPPLY-SCH } \\
\text { COOL-FT-MIN } \\
\text { HEATING-CAPACITY } \\
\text { FURNACE-AUX } \\
\text { FURNACE-AUX-IKW } \\
\text { FURNACE-HIR } \\
\text { FURNACE-HIR-FPLR } \\
\text { FURNACE-OFF-LOSS }\end{array}$ & $\begin{array}{l}\text { Dependent on peak loads } \\
\text { Standard curve SDL-C10 } \\
\text { From loads } \\
\text { Standard curve SDL-C30 } \\
0.14 \\
\text { Standard curve SDL-C40 } \\
\text { Standard curve SDL-C50 } \\
\text { Standard curve SDL-C161 } \\
\text { uses MIN-SUPPLY-T } \\
70.0^{\circ} \mathrm{F} \\
\text { Dependent on peak loads } \\
800.0 \mathrm{Btu} / \mathrm{hr} \\
0.0 \mathrm{~kW} \\
1.35 \mathrm{Btu} / \text { Btu } \\
\text { Standard curve SDL-C111 } \\
\text { No loss accounted for }\end{array}$ \\
\hline
\end{tabular}


SYSTEM-EQUIPMENT keywords

For Packaged Systems

System Types PMZS and PVAVS

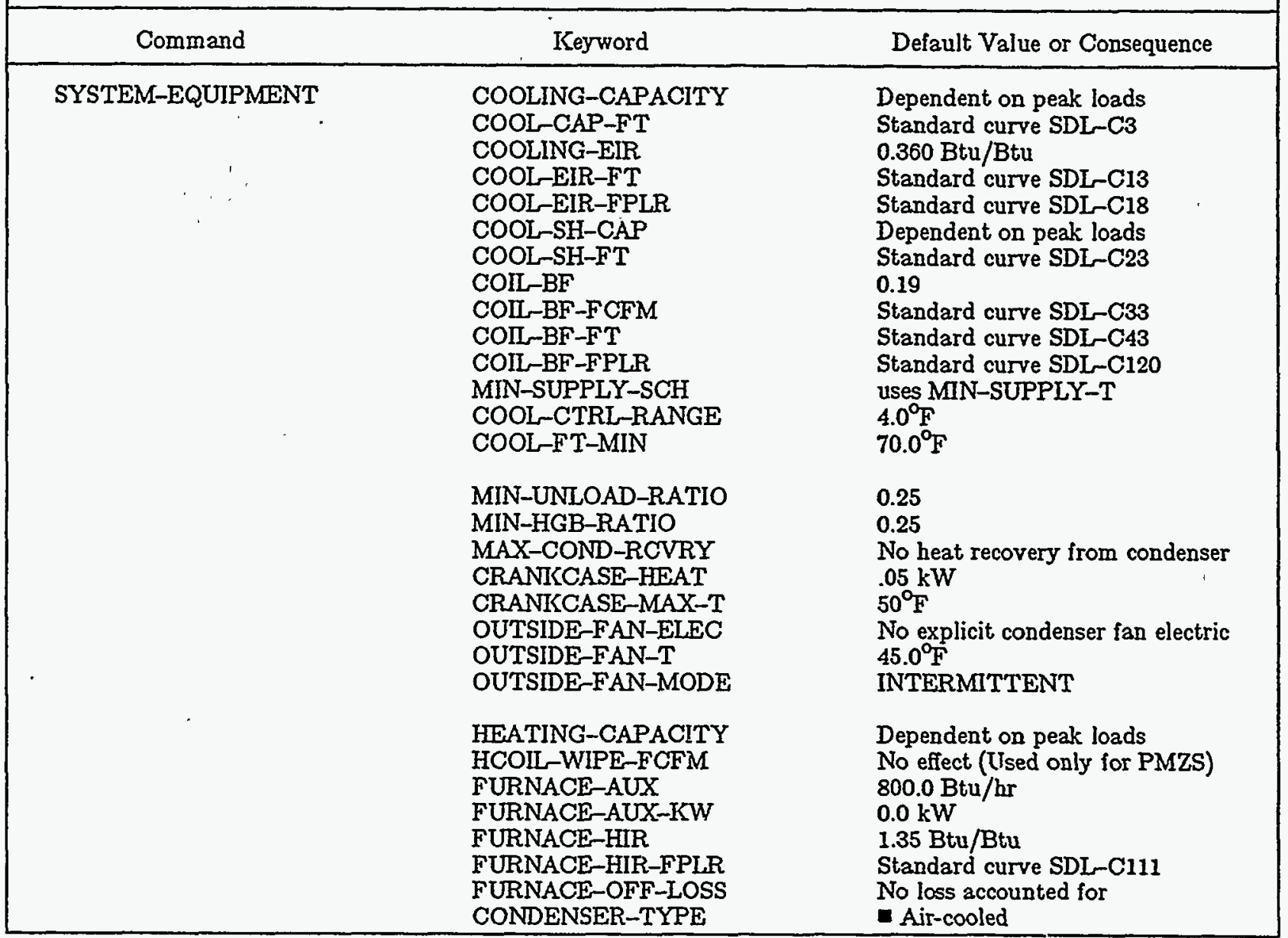




\begin{tabular}{|c|c|c|}
\hline \multicolumn{3}{|c|}{$\begin{array}{c}\text { SYSTEM-EQUIPMENT keywords } \\
\text { For Packaged Systems } \\
\text { System Type PVVT }\end{array}$} \\
\hline Command & Keyword & Default Value or Consequence \\
\hline SYSTEM-EQUIPMENT & $\begin{array}{l}\text { COII-BF } \\
\text { COI-BF-FFLOW } \\
\text { COI-BF-FPLR } \\
\text { COI-BF-FT } \\
\text { COMPRESSOR-TYPE } \\
\text { CONDENSER-TYPE } \\
\text { COOL-CAP-FT } \\
\text { COOL-CTRI-RANGE } \\
\text { COOL-EIR-FPLR } \\
\text { COOL-EIR-FT } \\
\text { COOL-FT-MIN } \\
\text { COOL-SH-FT } \\
\text { COOLING-EIR } \\
\text { CRANKCASE-HEAT } \\
\text { CRANKCASE-MAX-T } \\
\text { DEFROST-CTRL } \\
\text { DEFROST-T } \\
\text { DEFROST-TYPE } \\
\text { DIRECT-EFF } \\
\text { DIRECT-EFF-FFLOW } \\
\text { EVAP-CL+M-SUP } \\
\text { EVAP-CL+REC-RA } \\
\text { EVAP-CL-AIR } \\
\text { EVAP-CL-KW/FLOW } \\
\text { EVAP-CL-LIMIT-T } \\
\text { EVAP-CL-TYPE } \\
\text { EVAP-PCC-EFF } \\
\text { EVAP-PCC-ELEC } \\
\text { EVAP-PCC-SCH } \\
\text { FURNACE-AUX } \\
\text { FURNACE-HIR } \\
\text { FURNACE-HIR-FPLR } \\
\text { HEAT-CAP-FT } \\
\text { HEAT-EIR-FPLR } \\
\text { HEAT-EIR-FT } \\
\text { HEATING-EIR } \\
\text { HP-SUPP-HT-CAP } \\
\text { HP-SUPP-SOURCE } \\
\text { INDIR-EFF } \\
\text { INDIR-EFF-FFLOW } \\
\text { MAX-HP-SUPP-T } \\
\text { MIN-HGB-RATIO } \\
\text { MIN-HP-T } \\
\text { MIN-SUPPLY-SCH } \\
\text { MIN-UNLOAD-RATIO } \\
\text { OUTSIDE-FAN-CFLT } \\
\text { OUTSIDE-FAN-ELEC } \\
\text { OUTSIDE-FAN-MODE } \\
\text { OUTSIDE-FAN-T } \\
\text { RESIST-CAP-RATIO } \\
\text { WS-ECONO-XEFF } \\
\end{array}$ & 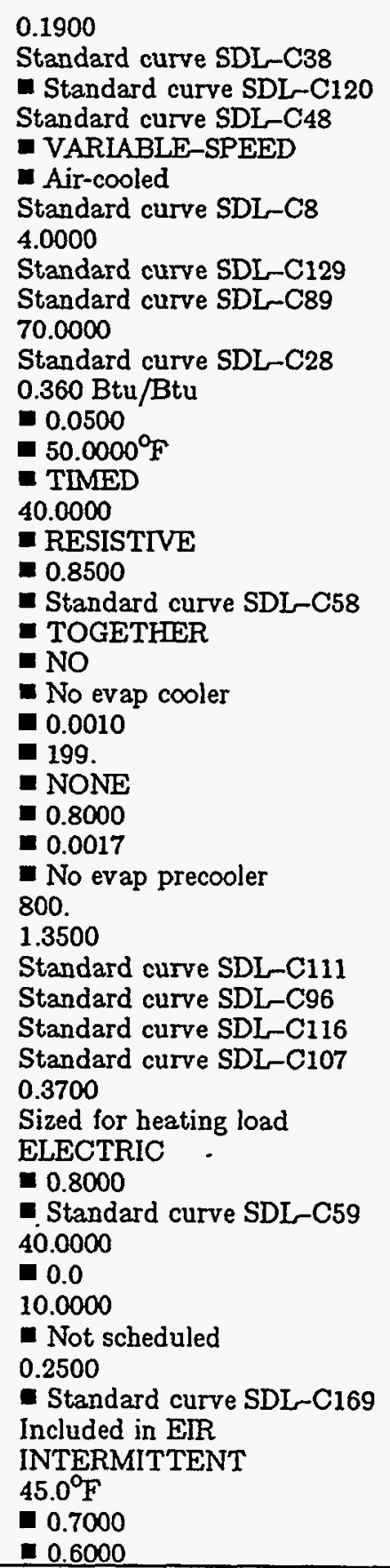 \\
\hline
\end{tabular}




\section{VERIFICATION AND SUMMARY REPORTS}

LOADS Verification Reports

Code-word
LV-A
LV-B
LV-C
LV-D
LV-E
LV-F
LV-G
LV-H
LV-I
LV-J
LV-K
LV-L
LV-M
ALL-VERIFICATION

Title/description

GENERAL PROJECT AND BUILDING INPUT

SUMMARY OF SPACES OCCURRING IN THE PROJECT

DETAILS OF SPACE

DETAILS OF EXTERIOR SURFACES IN THE PROJECT

DETAILS OF UNDERGROUND SURFACES IN THE PROJECT

DETAILS OF INTERIOR SURFACES IN THE PROJECT

DETAILS OF SCHEDULES OCCURRING IN THE PROJECT

DETAILS OF WINDOWS OCCURRING IN THE PROJECT

DETAILS OF CONSTRUCTIONS OCCURRING IN THE PROJECT

DETAILS OF BUILDING SHADES IN THE PROJECT

WEIGHTING FACTOR SUMMARY

DAYLIGHT FACTOR SUMMARY

DOE-2 UNITS TABLE (English/Metric Conversion Table)

LOADS Summary Reports

LS-A

LS-B

LS-C

LS-D

LS-E

LS-F

LS-G

LS-H

LS-I

LS-J

LS-K

LS-L

ALI-SUMMARY
SPACE PEAIK LOADS SUMMARY

SPACE PEAI LOAD COMPONENTS

BUILDING PEAK LOAD COMPONENTS

BUILDING MONTHLY LOADS SUMMARY

SPACE MONTHLY LOAD COMPONENTS IN MBtu

BUILDING MONTHLY LOAD COMPONENTS IN MBtu

SPACE DAYLIGHTING SUMMARY

PERCENT LIGHTING ENERGY REDUCTION BY DAYLIGHT, <space>

PERCENT LIGHTING ENERGY REDUCTION BY DAYLIGHT, BUILDING

DAYLIGHT ILLUMINANCE FREQUENCY OF OCCURRENCE

SPACE INPUT FUELS SUMMARY

MANAGEMENT AND SOLAR SUMMARY FOR SPACE

All summary reports

SYSTEMS Verification Reports

SV-A

SYSTEM DESIGN PARAMETERS

SV-A

SYSTEM DESIGN PARAMETERS (Refrigerated Equipment in <space>)

SV-B

REPORT-ONLY

ZONE FAN DATA for <system>

Requested report printed; no simulation of SYSTEMS or PLANT performed.

SYSTEMS Summary Reports

SS-A

SS-B

SYSTEM MONTHLY LOADS SUMMARY

SYSTEM MONTHUY LOADS SUMMARY

SYSTEM MONTHLY LOAD HOURS

PLANT MONTHLY LOADS SUMMARY

PLANT MONTHLY LOAD HOURS

ZONE DEMAND SUMMARY

ZONE LOADS SUMMARY

SYSTEM MONTHLY LOADS SUMMARY

SYSTEM MONTHLY SENSIBLE-LATENT SUMMARY

SYSTEM PEAIK HEATING AND COOLING DAYS

SPACE TEMPERATURE SUMMARY

FAN ELECTRIC ENERGY FOR < system>

FAN ELECTRIC ENERGY FOR PLANT

RELATIVE HUMIDITY SCATTER PLOT

TEMPERATURE SCATTER PLOT

- = Required keyword 


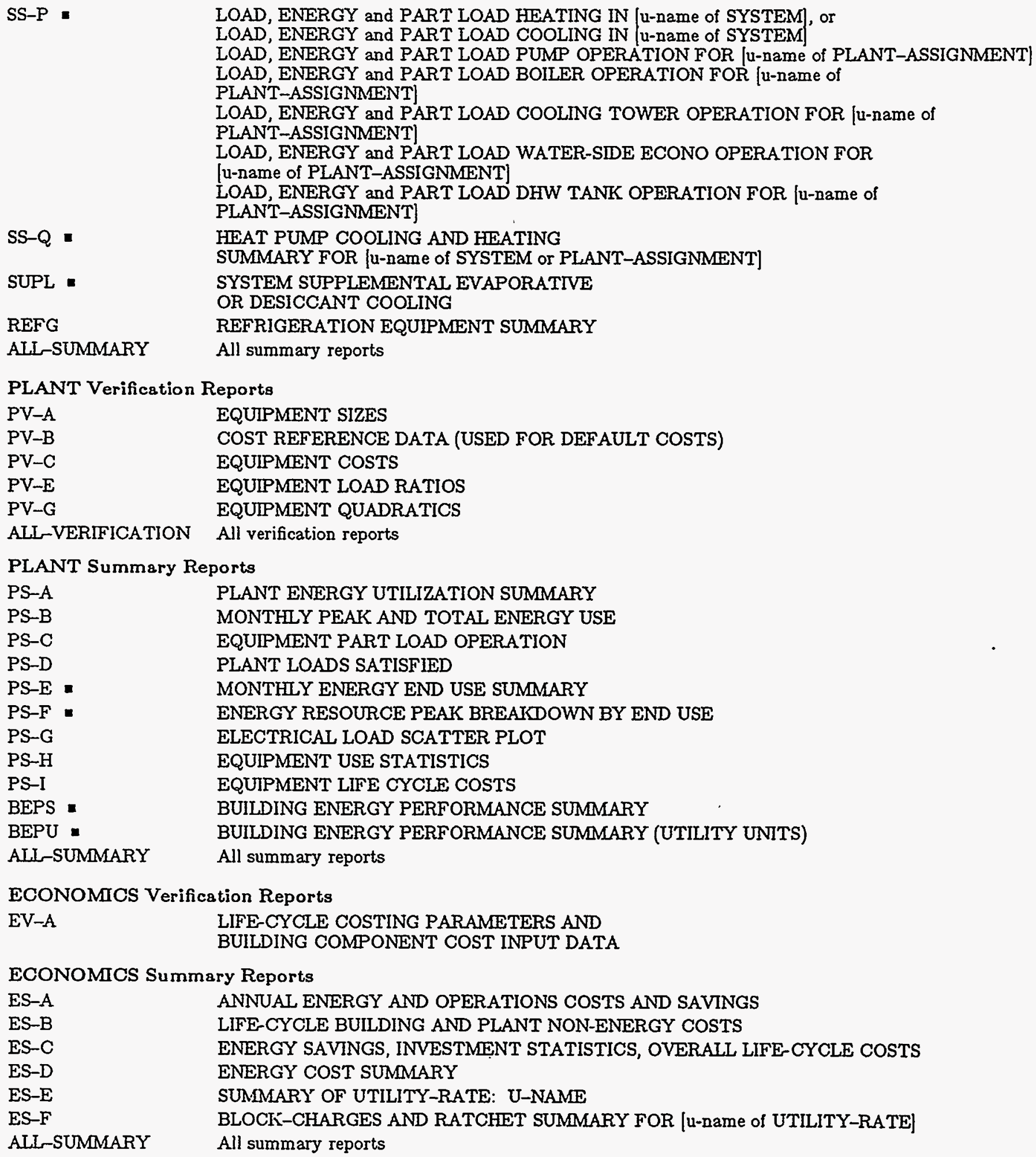

ES-A

ES-B

ES-C

ES-D

ES-E

ES-F

ALI-SUMMARY

ANNUAL ENERGY AND OPERATIONS COSTS AND SAVINGS

LIFE-CYCLE BUILDING AND PLANT NON-ENERGY COSTS

ENERGY SAVINGS, INVESTMENT STATISTICS, OVERALL LIFE-CYCLE COSTS ENERGY COST SUMMARY SUMMARY OF UTILITY-RATE: U-NAME

BLOCK-CHARGES AND RATCHET SUMMARY FOR [U-name of UTILITY-RATE] All summary reports 


\section{MATERIALS LIBRARY}

\section{Thermal Properties of Building Materials}

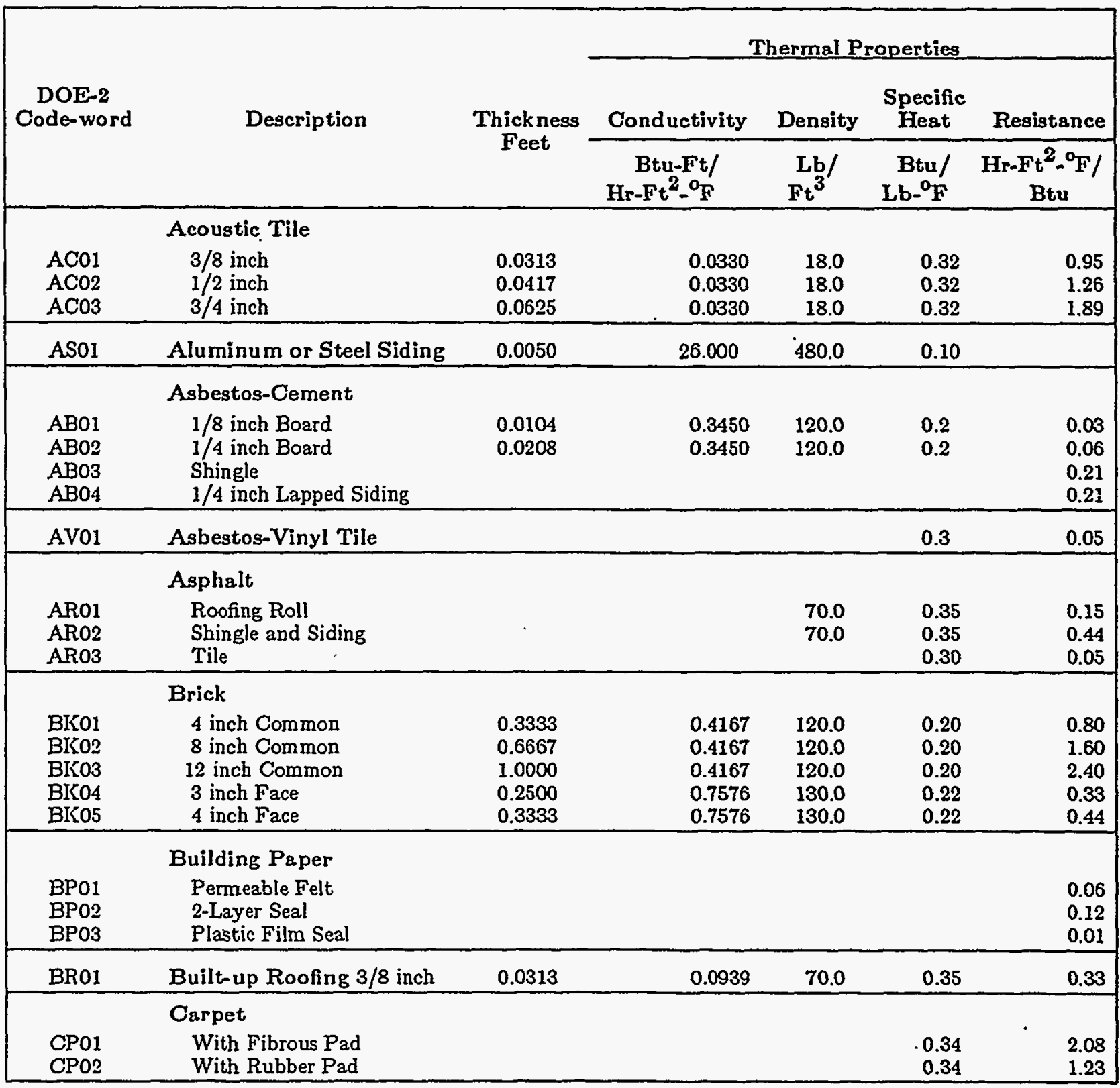




\section{Thermal Properties of Building Materials -- Continued}

\begin{tabular}{|c|c|c|c|c|c|c|}
\hline \multirow{3}{*}{$\begin{array}{c}\text { DOE-2 } \\
\text { Code-word }\end{array}$} & \multirow{3}{*}{ Description } & \multirow{3}{*}{$\begin{array}{c}\text { Thickness } \\
\text { Feet }\end{array}$} & \multicolumn{4}{|c|}{ Thermal Properties } \\
\hline & & & Conductivity & Density & $\begin{array}{l}\text { Specific } \\
\text { Heat }\end{array}$ & Resistance \\
\hline & & & $\begin{array}{r}\text { Btu-Ft/ } \\
\mathrm{Hr}-\mathrm{Ft}^{2}-{ }^{0} \mathrm{~F} \\
\end{array}$ & $\begin{array}{l}\mathrm{Lb} / \\
\mathrm{Ft}^{3} \\
\end{array}$ & $\begin{array}{r}\text { Btu/ } \\
\text { Lb- }{ }^{\circ} \mathbf{F} \\
\end{array}$ & $\begin{array}{c}\mathrm{Hr}-\mathrm{Ft}^{2}-\mathrm{O}^{\mathrm{F}} / \\
\mathrm{Btu} \\
\end{array}$ \\
\hline \multicolumn{7}{|c|}{ Cement } \\
\hline $\begin{array}{l}\text { CMO1 } \\
\text { CMO2 } \\
\text { CMO3 }\end{array}$ & $\begin{array}{l}1 \text { inch Mortar } \\
1.75 \text { inch Mortar } \\
1 \text { inch Plaster with } \\
\text { Sand Aggregate }\end{array}$ & $\begin{array}{l}0.0833 \\
0.1458 \\
0.0833\end{array}$ & $\begin{array}{l}0.4167 \\
0.4167 \\
0.4167\end{array}$ & $\begin{array}{l}116.0 \\
116.0 \\
116.0\end{array}$ & $\begin{array}{l}0.2 \\
0.2 \\
0.2\end{array}$ & $\begin{array}{l}0.20 \\
0.35 \\
0.20\end{array}$ \\
\hline \multicolumn{7}{|c|}{ Clay Tile, Hollow } \\
\hline $\begin{array}{l}\text { CT01 } \\
\text { CT02 } \\
\text { CT03 } \\
\text { CT04 } \\
\text { CT05 } \\
\text { CT06 } \\
\end{array}$ & $\begin{array}{l}3 \text { inch } 1 \text { Cell } \\
4 \text { inch } 1 \text { Cell } \\
6 \text { inch } 2 \text { Cells } \\
8 \text { inch } 2 \text { Cells } \\
10 \text { inch } 2 \text { Cells } \\
12 \text { inch } 3 \text { Cells }\end{array}$ & $\begin{array}{l}0.2500 \\
0.3333 \\
0.5000 \\
0.6667 \\
0.8333 \\
1.0000 \\
\end{array}$ & $\begin{array}{l}0.3125 \\
0.2999 \\
0.3300 \\
0.3600 \\
0.3749 \\
0.4000 \\
\end{array}$ & $\begin{array}{l}70.0 \\
70.0 \\
70.0 \\
70.0 \\
70.0 \\
70.0 \\
\end{array}$ & $\begin{array}{l}0.2 \\
0.2 \\
0.2 \\
0.2 \\
0.2 \\
0.2 \\
\end{array}$ & $\begin{array}{l}0.80 \\
1.11 \\
1.52 \\
1.85 \\
2.22 \\
2.50 \\
\end{array}$ \\
\hline \multirow[t]{2}{*}{ CT11 } & $\begin{array}{l}\text { Clay Tile, Paver } \\
3 / 8 \text { inch }\end{array}$ & 0.0313 & 1.0416 & 120.0 & 0.2 & 0.03 \\
\hline & \multicolumn{6}{|c|}{$\begin{array}{l}\text { Concrete, Heavy Weight } \\
\text { Dried Aggregate, } 140 \text { lbs. }\end{array}$} \\
\hline $\begin{array}{l}\mathrm{CCO} 1 \\
\mathrm{CCO} 2 \\
\mathrm{CCO} 3 \\
\mathrm{CCO} 4 \\
\mathrm{CCO} 5 \\
\mathrm{CCO6} \\
\mathrm{CCO} 7 \\
\end{array}$ & $\begin{array}{l}1.25 \text { inch } \\
2 \text { inch } \\
4 \text { inch } \\
6 \text { inch } \\
8 \text { inch } \\
10 \text { inch } \\
12 \text { inch } \\
\end{array}$ & $\begin{array}{l}0.1042 \\
0.1667 \\
0.3333 \\
0.5000 \\
0.6667 \\
0.8333 \\
1.0000 \\
\end{array}$ & $\begin{array}{l}0.7576 \\
0.7576 \\
0.7576 \\
0.7576 \\
0.7576 \\
0.7576 \\
0.7576 \\
\end{array}$ & $\begin{array}{l}140.0 \\
140.0 \\
140.0 \\
140.0 \\
140.0 \\
140.0 \\
140.0 \\
\end{array}$ & $\begin{array}{l}0.2 \\
0.2 \\
0.2 \\
0.2 \\
0.2 \\
0.2 \\
0.2 \\
\end{array}$ & $\begin{array}{l}0.14 \\
0.22 \\
0.44 \\
0.66 \\
0.88 \\
1.10 \\
1.32\end{array}$ \\
\hline \multicolumn{7}{|c|}{$\begin{array}{l}\text { Concrete, Heavy Weight } \\
\text { Undried Aggregate, } 140 \mathrm{lbs} .\end{array}$} \\
\hline $\begin{array}{l}\mathrm{CC} 11 \\
\mathrm{CC} 12 \\
\mathrm{CC} 13 \\
\mathrm{CC} 14 \\
\mathrm{CC} 15 \\
\mathrm{CC} 16 \\
\end{array}$ & $\begin{array}{l}3 / 4 \text { inch } \\
13 / 8 \text { inch } \\
31 / 4 \text { inch } \\
4 \text { inch } \\
6 \text { inch } \\
8 \text { inch }\end{array}$ & $\begin{array}{l}0.0625 \\
0.1146 \\
0.2708 \\
0.3333 \\
0.5000 \\
0.6667 \\
\end{array}$ & $\begin{array}{l}1.0417 \\
1.0417 \\
1.0417 \\
1.0417 \\
1.0417 \\
1.0417 \\
\end{array}$ & $\begin{array}{l}140.0 \\
140.0 \\
140.0 \\
140.0 \\
140.0 \\
140.0 \\
\end{array}$ & $\begin{array}{l}0.2 \\
0.2 \\
0.2 \\
0.2 \\
0.2 \\
0.2 \\
\end{array}$ & $\begin{array}{l}0.06 \\
0.11 \\
0.26 \\
0.32 \\
0.48 \\
0.64 \\
\end{array}$ \\
\hline \multicolumn{7}{|c|}{ Concrete, Light Weight, $80 \mathrm{lb}$. } \\
\hline $\begin{array}{l}\mathrm{CC} 21 \\
\mathrm{CC} 22 \\
\mathrm{CC} 23 \\
\mathrm{CC} 24 \\
\mathrm{CC} 25 \\
\mathrm{CC} 26 \\
\end{array}$ & $\begin{array}{l}3 / 4 \text { inch } \\
1.25 \text { inch } \\
2 \text { inch } \\
4 \text { inch } \\
6 \text { inch } \\
8 \text { inch }\end{array}$ & $\begin{array}{l}0.0625 \\
0.1042 \\
0.1667 \\
0.3333 \\
0.5000 \\
0.6667\end{array}$ & $\begin{array}{l}0.2083 \\
0.2083 \\
0.2083 \\
0.2083 \\
0.2083 \\
0.2083\end{array}$ & $\begin{array}{l}80.0 \\
80.0 \\
80.0 \\
80.0 \\
80.0 \\
80.0\end{array}$ & $\begin{array}{l}0.2 \\
0.2 \\
0.2 \\
0.2 \\
0.2 \\
0.2\end{array}$ & $\begin{array}{l}0.30 \\
0.50 \\
0.80 \\
1.60 \\
2.40 \\
3.20\end{array}$ \\
\hline
\end{tabular}




\section{Thermal Properties of Building Materials -- Continued}

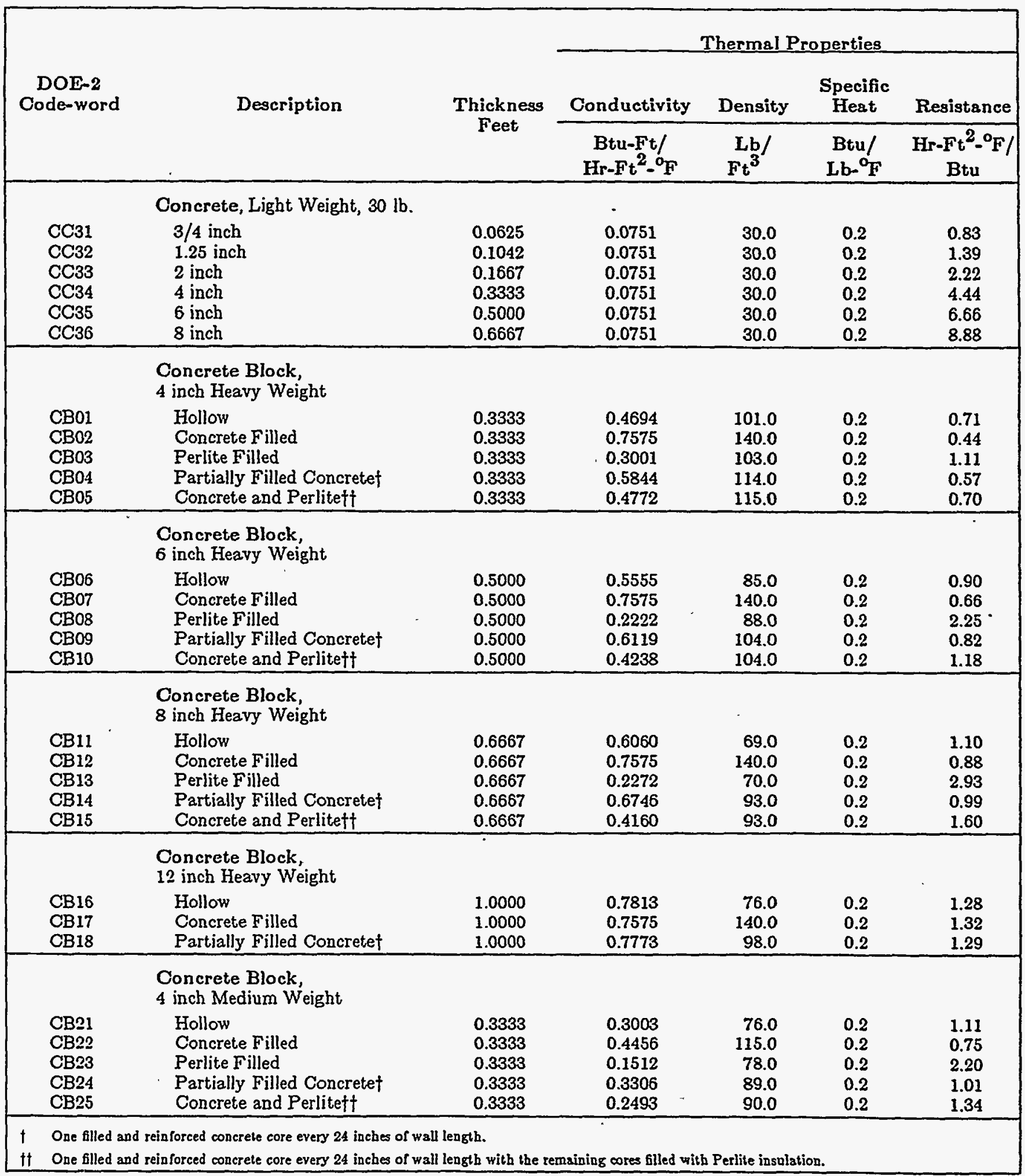




\section{Thermal Properties of Building Materials - Continued}

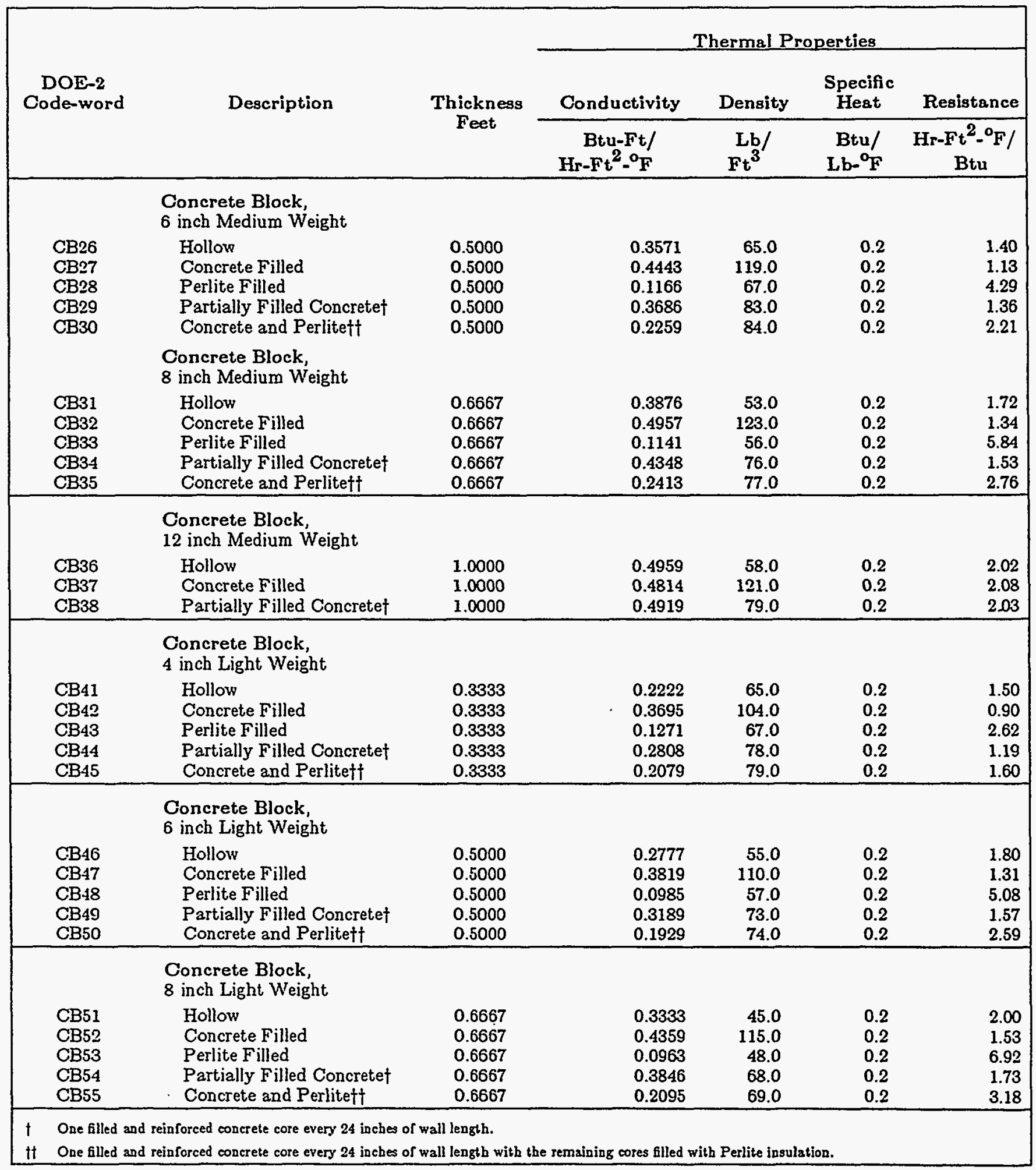




\section{Thermal Properties of Building Materials -- Continued}

\begin{tabular}{|c|c|c|c|c|c|c|}
\hline \multirow{3}{*}{$\begin{array}{c}\text { DOE-2 } \\
\text { Code-word }\end{array}$} & \multirow{3}{*}{ Description } & \multirow{3}{*}{$\begin{array}{c}\text { Thickness } \\
\text { Feet }\end{array}$} & \multicolumn{4}{|c|}{ Thermal Properties } \\
\hline & & & Conductivity & Density & $\begin{array}{c}\text { Specific } \\
\text { Hest }\end{array}$ & Resistance \\
\hline & & & $\begin{array}{r}\text { Btu-Ft/ } \\
\text { Hr-Ft }{ }^{2}-{ }^{\circ} \mathrm{F}\end{array}$ & $\begin{array}{r}\mathbf{L b} / \\
\mathrm{Ft}^{3} \\
\end{array}$ & $\begin{array}{r}\text { Btu/ } \\
\mathbf{L b}-{ }^{0} \mathbf{F} \\
\end{array}$ & $\begin{array}{c}\mathrm{Hr}-\mathrm{Ft} \mathrm{t}^{2}-{ }^{0} \mathrm{~F} / \\
\mathrm{Btu}\end{array}$ \\
\hline \multirow[b]{2}{*}{$\begin{array}{l}\text { CB56 } \\
\text { CB57 } \\
\text { CB58 } \\
\end{array}$} & $\begin{array}{l}\text { Concrete Block, } \\
12 \text { inch Light Weight }\end{array}$ & & & & & \\
\hline & $\begin{array}{l}\text { Hollow } \\
\text { Concrete Filled } \\
\text { Partially Filled Concreteł }\end{array}$ & $\begin{array}{l}1.0000 \\
1.0000 \\
1.0000\end{array}$ & $\begin{array}{l}0.4405 \\
0.4194 \\
0.4274\end{array}$ & $\begin{array}{r}49.0 \\
113.0 \\
70.0\end{array}$ & $\begin{array}{l}0.2 \\
0.2 \\
0.2\end{array}$ & $\begin{array}{l}2.27 \\
2.38 \\
2.34\end{array}$ \\
\hline \multirow[b]{2}{*}{$\begin{array}{l}\text { GP01 } \\
\text { GP02 } \\
\text { GP03 } \\
\end{array}$} & Gypsum or Plaster Board & & & & & \\
\hline & $\begin{array}{l}1 / 2 \text { inch } \\
5 / 8 \text { inch } \\
3 / 4 \text { inch }\end{array}$ & $\begin{array}{l}0.0417 \\
0.0521 \\
0.0625 \\
\end{array}$ & $\begin{array}{l}0.0926 \\
0.0926 \\
0.0926 \\
\end{array}$ & $\begin{array}{l}50.0 \\
50.0 \\
50.0\end{array}$ & $\begin{array}{l}0.2 \\
0.2 \\
0.2 \\
\end{array}$ & $\begin{array}{l}0.45 \\
0.56 \\
0.67 \\
\end{array}$ \\
\hline \multirow[b]{2}{*}{$\begin{array}{l}\text { GP04 } \\
\text { GP05 } \\
\text { GP06 } \\
\text { GP07 }\end{array}$} & Gypsum Plaster & & & & & \\
\hline & $\begin{array}{l}3 / 4 \text { inch Light Weight Aggregate } \\
1 \text { inch Light Weight Aggregate } \\
3 / 4 \text { inch Sand Aggregate } \\
1 \text { inch Sand Aggregate }\end{array}$ & $\begin{array}{l}0.0625 \\
0.0833 \\
0.0625 \\
0.0833\end{array}$ & $\begin{array}{l}0.1330 \\
0.1330 \\
0.4736 \\
0.4736 \\
\end{array}$ & $\begin{array}{r}45.0 \\
45.0 \\
105.0 \\
105.0 \\
\end{array}$ & $\begin{array}{l}0.2 \\
0.2 \\
0.2 \\
0.2 \\
\end{array}$ & $\begin{array}{l}0.47 \\
0.63 \\
0.13 \\
0.18 \\
\end{array}$ \\
\hline & Hard Board, $3 / 4$ inch & & & & & \\
\hline $\begin{array}{l}\text { HB01 } \\
\text { HB02 } \\
\text { HB03 } \\
\text { HB04 }\end{array}$ & $\begin{array}{l}\text { Medium Density Siding } \\
\text { Medium Density Others } \\
\text { High Density Standard Tempered } \\
\text { High Density Service Tempered }\end{array}$ & $\begin{array}{l}0.0625 \\
0.0625 \\
0.0625 \\
0.0625 \\
\end{array}$ & $\begin{array}{l}0.0544 \\
0.0608 \\
0.0683 \\
0.0833 \\
\end{array}$ & $\begin{array}{l}40.0 \\
50.0 \\
55.0 \\
63.0\end{array}$ & $\begin{array}{l}0.28 \\
0.31 \\
0.33 \\
0.33 \\
\end{array}$ & $\begin{array}{l}1.15 \\
1.03 \\
0.92 \\
0.75 \\
\end{array}$ \\
\hline \multirow[t]{2}{*}{ LT01 } & Linoleum Tile & & & & 0.30 & 0.05 \\
\hline & Particle Board & & & & & \\
\hline $\begin{array}{l}\text { PB01 } \\
\text { PB02 } \\
\text { PB03 } \\
\text { PB04 }\end{array}$ & $\begin{array}{l}\text { Low Density } 3 / 4 \text { inch } \\
\text { Medium Density } 3 / 4 \text { inch } \\
\text { High Density } 3 / 4 \text { inch } \\
\text { Underlayment } 5 / 8 \text { inch }\end{array}$ & $\begin{array}{l}0.0625 \\
0.0625 \\
0.0625 \\
0.0521\end{array}$ & $\begin{array}{l}0.0450 \\
0.7833 \\
0.9833 \\
0.1796\end{array}$ & $\begin{array}{l}75.0 \\
75.0 \\
75.0 \\
75.0\end{array}$ & $\begin{array}{l}0.31 \\
0.31 \\
0.31 \\
0.29\end{array}$ & $\begin{array}{l}1.39 \\
0.08 \\
0.06 \\
0.29\end{array}$ \\
\hline
\end{tabular}


1. Thermal Properties of Building Materials -- Continued

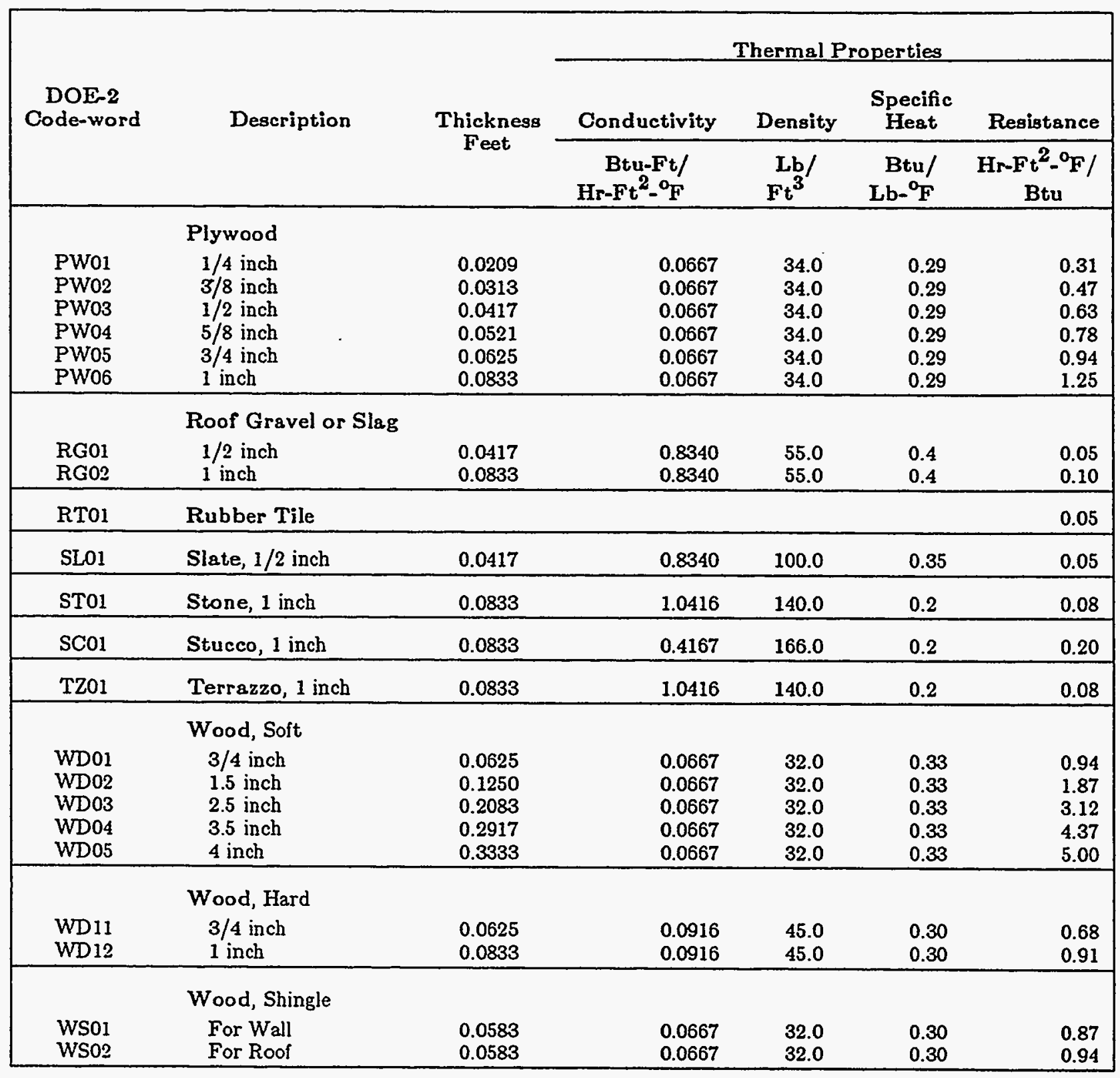




\section{Thermal Properties of Insulating Materials}

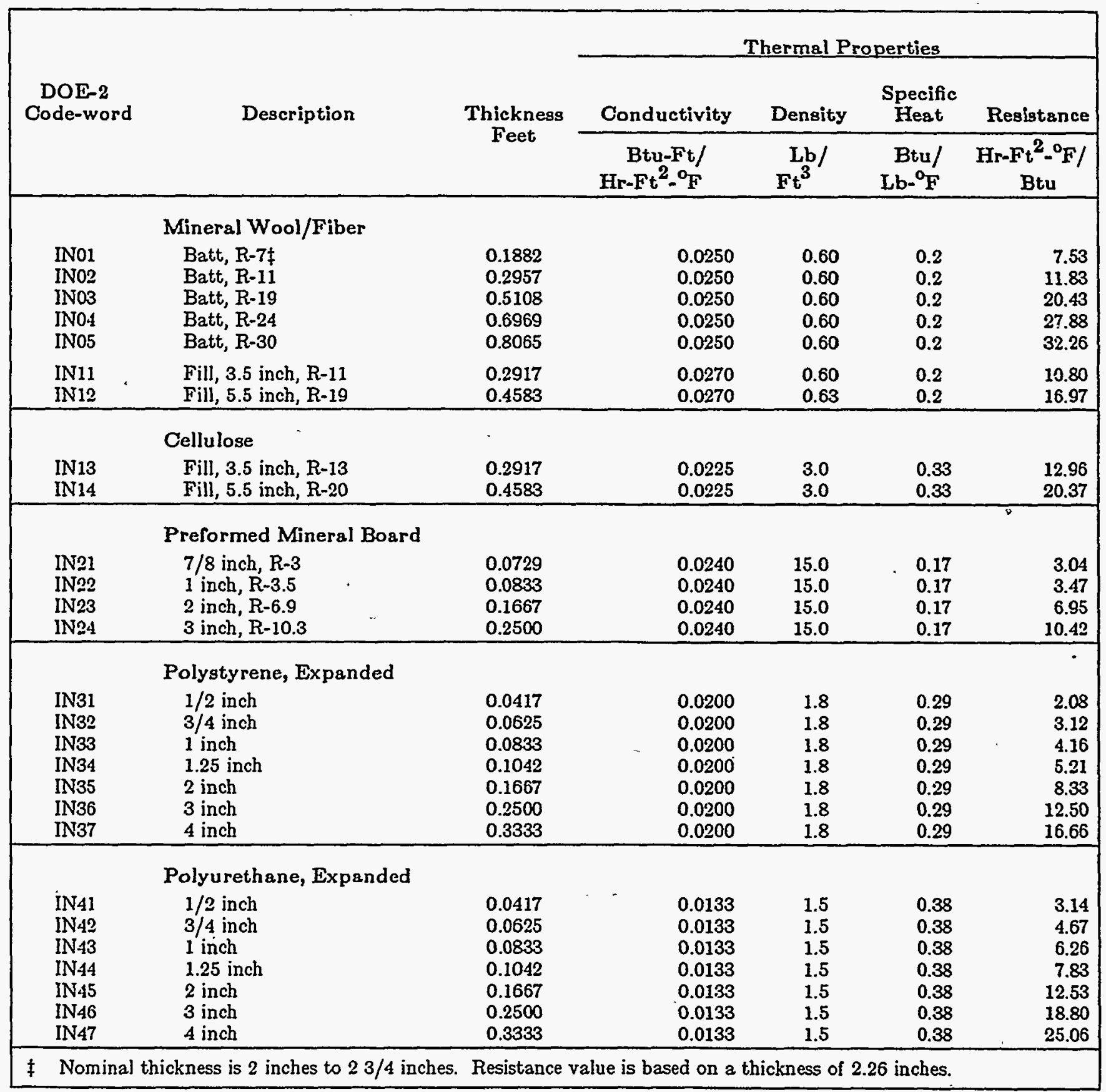




\section{Thermal Properties of Insulating Materials - continued}

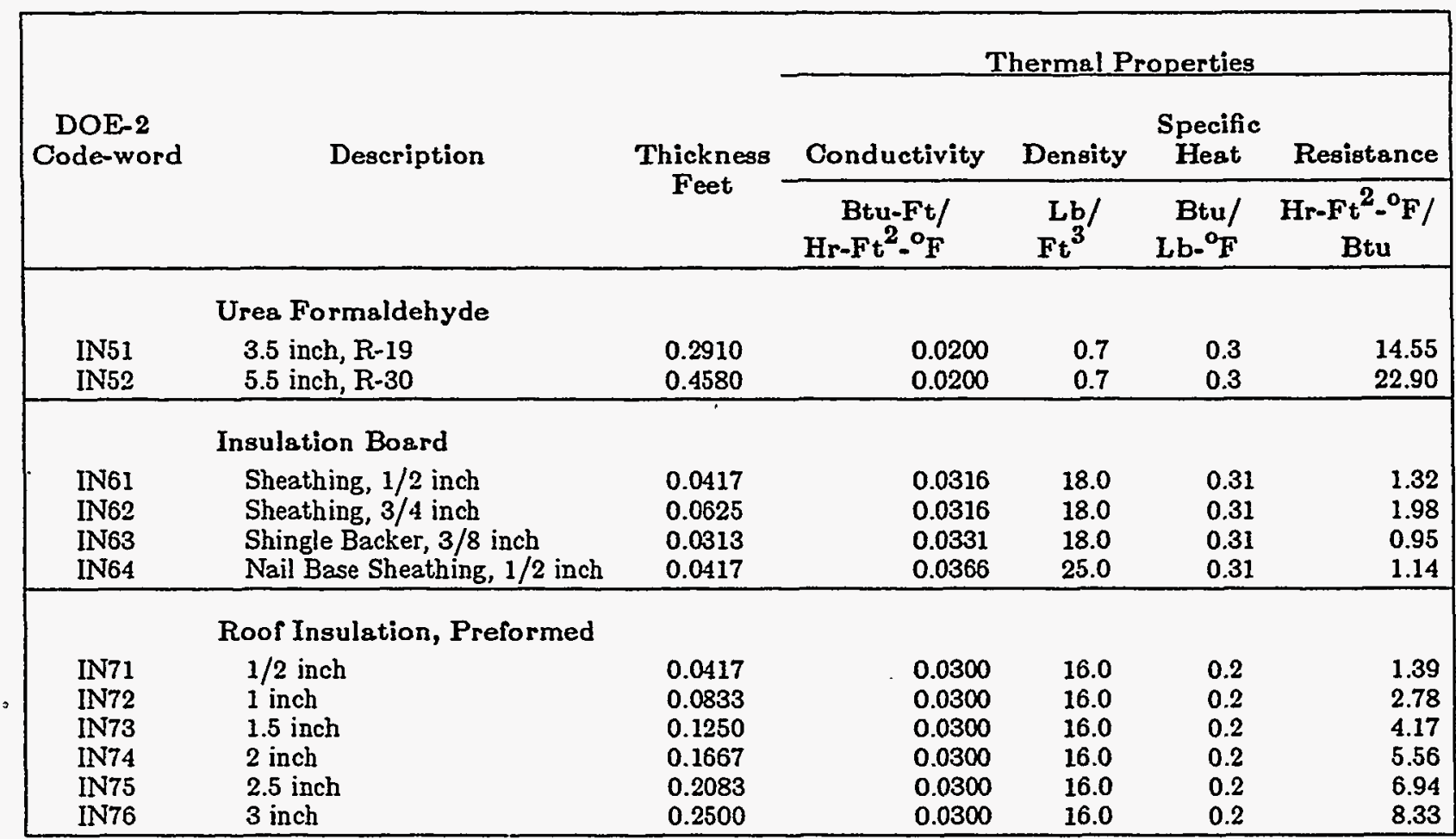

\section{Thermal Properties of Air Spaces}

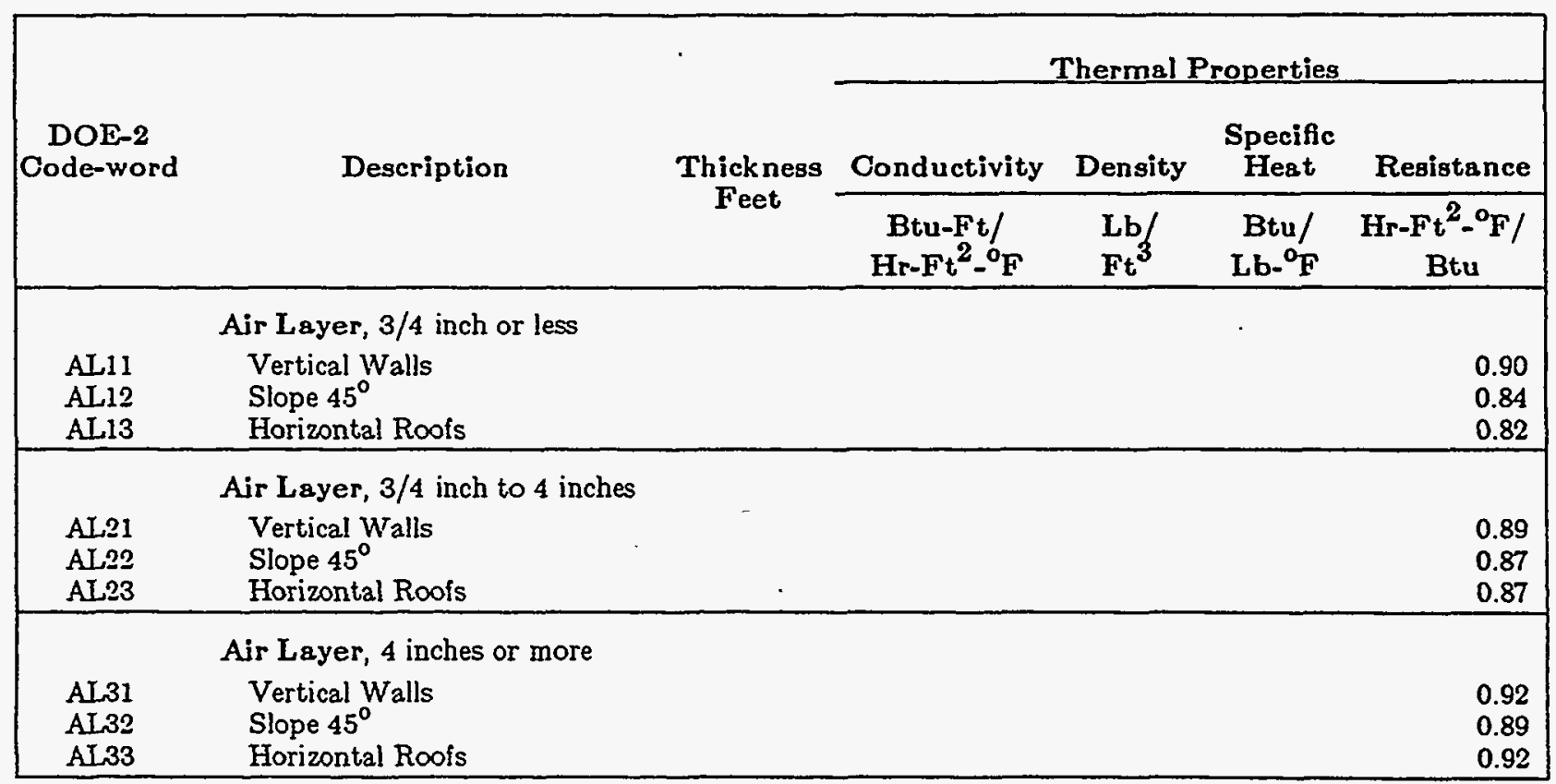

Note: A more extensive list of data can be found in the 1989 ASHRAE Handbook of Fundamentals, Chap. 22, Table 2. 
Index to the Window Library

\begin{tabular}{llllllllllll} 
G-T-C & WINDOW & U-SI & U-IP & SC & SHGC & Tsol & Risol & Tris & Rfvis & ID & WID \\
\hline SINGLE CLEAR & & & & & & & & & & \\
1000 & CLEAR & 6.31 & 1.11 & 1.00 & .86 & .84 & .08 & .90 & .08 & 2 & 3.0 \\
1001 & CLEAR & 6.17 & 1.09 & .95 & .81 & .77 & .07 & .88 & .08 & 3 & 6.0 \\
1002 & LOW IRON & 6.31 & 1.11 & 1.05 & .90 & .90 & .08 & .91 & .08 & 14 & 3.0 \\
1003 & LOW IRON & 6.22 & 1.10 & 1.04 & .90 & .89 & .08 & .91 & .08 & 16 & 5.0
\end{tabular}

SINGLE TINT

$\begin{array}{llllllllllll}1200 & \text { BRONZE } & 6.31 & 1.11 & .84 & .73 & .64 & .06 & .69 & .06 & 5 & 3.0 \\ 1201 & \text { BRONZE } & 6.17 & 1.09 & .71 & .61 & .48 & .05 & .53 & .06 & 6 & 6.0 \\ 1202 & \text { GREEN } & 6.31 & 1.11 & .83 & .72 & .63 & .06 & .82 & .08 & 11 & 3.0 \\ 1203 & \text { GREEN } & 6.17 & 1.09 & .71 & .61 & .49 & .06 & .75 & .07 & 12 & 6.0 \\ 1204 & \text { GREY } & 6.31 & 1.11 & .83 & .71 & .63 & .06 & .61 & .06 & 8 & 3.0 \\ 1205 & \text { GREY } & 6.17 & 1.09 & .69 & .59 & .46 & .05 & .43 & .05 & 9 & 6.0 \\ 1206 & \text { BLUE } & 6.17 & 1.09 & .71 & .61 & .48 & .05 & .57 & .06 & 17 & 6.0\end{array}$

SINGLE REF A

$\begin{array}{llllllllllll}1400 & \text { CLEAR-L } & 4.90 & .86 & .23 & .19 & .07 & .34 & .08 & .41 & 200 & 6.0 \\ 1401 & \text { CLEAR-M } & 5.11 & .90 & .29 & .25 & .11 & .27 & .14 & .31 & 201 & 6.0 \\ 1402 & \text { CLEAR-H } & 5.41 & .95 & .36 & .31 & .16 & .22 & .20 & .25 & 202 & 6.0 \\ 1403 & \text { TINT-L } & 4.93 & .87 & .26 & .22 & .04 & .15 & .05 & .17 & 210 & 6.0 \\ 1404 & \text { TINT-M } & 5.11 & .90 & .29 & .25 & .06 & .13 & .09 & .14 & 211 & 6.0 \\ 1405 & \text { TINT-H } & 5.29 & .93 & .34 & .29 & .10 & .11 & .10 & .11 & 212 & 6.0\end{array}$

SINGLE REF B

$\begin{array}{llllllllllll}1406 & \text { CLEAR-L } & 5.44 & .96 & .35 & .31 & .15 & .22 & .20 & .23 & 220 & 6.0 \\ 1407 & \text { CLEAR-H } & 5.50 & .97 & .45 & .39 & .24 & .16 & .30 & .16 & 221 & 6.0 \\ 1408 & \text { TINT-L } & 4.93 & .87 & .26 & .23 & .04 & .13 & .05 & .09 & 230 & 6.0 \\ 1409 & \text { TINT-M } & 5.05 & .89 & .33 & .28 & .10 & .11 & .13 & .10 & 231 & 6.0 \\ 1410 & \text { TINT-H } & 5.50 & .97 & .40 & .34 & .15 & .09 & .18 & .08 & 232 & 6.0\end{array}$

SINGLE REF $C$

$\begin{array}{llllllllllll}1411 & \text { CLEAR-L } & 4.99 & .88 & .29 & .25 & .11 & .25 & .13 & .28 & 240 & 6.0 \\ 1412 & \text { CLEAR-M } & 5.23 & .92 & .37 & .32 & .17 & .20 & .19 & .21 & 241 & 6.0 \\ 1413 & \text { CLEAR-H } & 5.35 & .94 & .41 & .35 & .20 & .16 & .22 & .17 & 242 & 6.0 \\ 1414 & \text { TINT-L } & 4.99 & .88 & .29 & .25 & .07 & .13 & .08 & .13 & 250 & 6.0 \\ 1415 & \text { TINT-M } & 5.23 & .92 & .34 & .29 & .10 & .10 & .11 & .10 & 251 & 6.0 \\ 1416 & \text { TINT-H } & 5.35 & .94 & .37 & .31 & .12 & .09 & .13 & .09 & 252 & 6.0\end{array}$

SINGLE REF D

$\begin{array}{llllllllllll}1417 & \text { CLEAR } & 6.12 & 1.08 & .58 & .50 & .43 & .31 & .33 & .45 & 260 & 6.0 \\ 1418 & \text { TINT } & 6.12 & 1.08 & .53 & .46 & .30 & .14 & .25 & .18 & 270 & 6.0\end{array}$

SINGLE LOW-E CLEAR

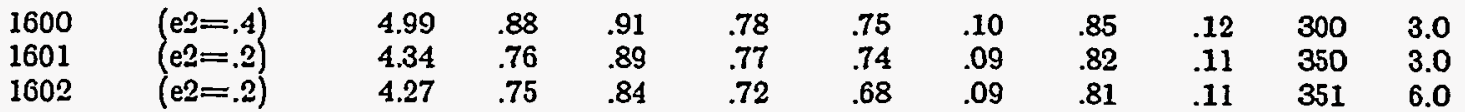

SINGLE ELECTROCHROMIC ABSORBING BLEACHED/COLORED

$\begin{array}{lllllllllll}1800 & 6.17 & 1.09 & .98 & .84 & .81 & .09 & .85 & .10 & 700 & 6.0 \\ 1801 & 6.17 & 1.09 & .36 & .31 & .11 & .18 & .13 & .08 & 701 & 6.0\end{array}$

SINGLE ELECTROCHROMIC REFLECTING BLEACHED/COLORED

$\begin{array}{lllllllllll}1802 & 6.17 & 1.09 & .85 & .73 & .69 & .17 & .82 & .11 & 702 & 6.0 \\ 1803 & 6.17 & 1.09 & .34 & .29 & .10 & .22 & .16 & .07 & 703 & 6.0\end{array}$


Index to the Window Library (continued)

\begin{tabular}{lcccccccccccccc} 
& & & & & & & & \multicolumn{1}{c}{ LAY1 } & \multicolumn{1}{c}{ GAP1 } & \multicolumn{2}{c}{ LAY2 } \\
G-T-C & U-SI & U-IP & SC & SHGC & Tsol & Risol & Tvis & Rfvis & D & WID & GAS & WID & ID & WID \\
\hline DOUBLE CLEAR IG & & & & & & & & & & & & & \\
2000 & 3.23 & .57 & .88 & .76 & .70 & .13 & .81 & .15 & 2 & 3.0 & Air & 6.3 & 2 & 3.0 \\
2001 & 2.79 & .49 & .89 & .76 & .70 & .13 & .81 & .15 & 2 & 3.0 & Air & 12.7 & 2 & 3.0 \\
2002 & 2.61 & .46 & .89 & .76 & .70 & .13 & .81 & .15 & 2 & 3.0 & Arg & 12.7 & 2 & 3.0 \\
2003 & 3.16 & .56 & .81 & .69 & .60 & .11 & .78 & .14 & 3 & 6.0 & Air & 6.3 & 3 & 6.0 \\
2004 & 2.74 & .48 & .81 & .70 & .60 & .11 & .78 & .14 & 3 & 6.0 & Air & 12.7 & 3 & 6.0 \\
2005 & 2.56 & .45 & .81 & .70 & .60 & .11 & .78 & .14 & 3 & 6.0 & Arg & 12.7 & 3 & 6.0 \\
DOUBLE LOW IRON IG & & & & & & & & & & & \\
2006 & 3.23 & .57 & .96 & .83 & .81 & .14 & .84 & .15 & 14 & 3.0 & Air & 6.3 & 14 & 3.0 \\
2007 & 2.79 & .49 & .96 & .83 & .81 & .14 & .84 & .15 & 14 & 3.0 & Air & 12.7 & 14 & 3.0 \\
2008 & 2.61 & .46 & .96 & .83 & .81 & .14 & .84 & .15 & 14 & 3.0 & Arg & 12.7 & 14 & 3.0 \\
2009 & 3.18 & .56 & .95 & .82 & .80 & .14 & .83 & .15 & 16 & 5 & Air & 6.3 & 16 & 5.0 \\
2010 & 2.76 & .49 & .95 & .82 & .80 & .14 & .83 & .15 & 16 & 5 & Air & 12.7 & 16 & 5.0 \\
2011 & 2.58 & .45 & .95 & .82 & .80 & .14 & .83 & .15 & 16 & 5 & Arg & 12.7 & 16 & 5.0
\end{tabular}

DOUBLE TINT BRONZE IG

$\begin{array}{rrrrrrrrrrrrrrr}2200 & 3.23 & .57 & .72 & .62 & .54 & .09 & .62 & .10 & 5 & 3.0 & \text { Air } & 6.3 & 2 & 3.0 \\ 2201 & 2.79 & .49 & .72 & .62 & .54 & .09 & .62 & .10 & 5 & 3.0 & \text { Air } & 12.7 & 2 & 3.0 \\ 2202 & 2.61 & .46 & .72 & .62 & .54 & .09 & .62 & .10 & 5 & 3.0 & \text { Arg } & 12.7 & 2 & 3.0 \\ 2203 & 3.16 & .56 & .57 & .49 & .38 & .07 & .47 & .08 & 6 & 6.0 & \text { Air } & 6.3 & 3 & 6.0 \\ 2204 & 2.74 & .48 & .57 & .49 & .38 & .07 & .47 & .08 & 6 & 6.0 & \text { Air } & 12.7 & 3 & 6.0 \\ 2205 & 2.56 & .45 & .56 & .49 & .38 & .07 & .47 & .08 & 6 & 6.0 & \text { Arg } & 12.7 & 3 & 6.0\end{array}$

DOUBLE TINT GREEN IG

$\begin{array}{rrrrrrrrrrrrrrr}2206 & 3.23 & .57 & .72 & .62 & .53 & .09 & .74 & .13 & 11 & 3.0 & \text { Air } & 6.3 & 2 & 3.0 \\ 2207 & . .79 & .49 & .71 & .61 & .53 & .09 & .74 & .13 & 11 & 3.0 & \text { Air } & 12.7 & 2 & 3.0 \\ 2208 & 2.61 & .46 & .71 & .61 & .53 & .09 & .74 & .13 & 11 & 3.0 & \text { Arg } & 12.7 & 2 & 3.0 \\ 2209 & 3.16 & .56 & .58 & .50 & .38 & .07 & .66 & .12 & 12 & 6.0 & \text { Air } & 6.3 & 3 & 6.0 \\ 2210 & 2.74 & .48 & .57 & .49 & .38 & .07 & .66 & .12 & 12 & 6.0 & \text { Air } & 12.7 & 3 & 6.0 \\ 2211 & 2.56 & .45 & .57 & .49 & .38 & .07 & .66 & .12 & 12 & 6.0 & \text { Arg } & 12.7 & 3 & 6.0\end{array}$

DOUBLE TINT GREY IG

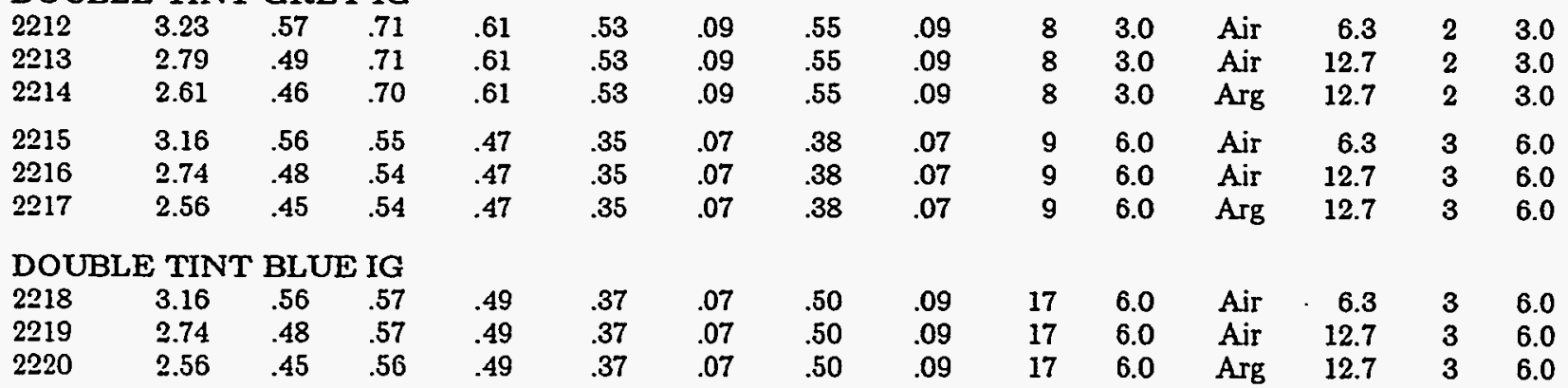

DOUBLE REF A CLEAR-L IG

\begin{tabular}{|c|c|c|c|c|c|c|c|c|c|c|c|c|c|c|}
\hline 2400 & 2.79 & .49 & .17 & .14 & .05 & .34 & .07 & .41 & 200 & 6.0 & Air & 6.3 & 3 & 6.0 \\
\hline 2401 & 2.26 & .40 & .15 & .13 & .05 & .34 & .07 & .41 & 200 & 6.0 & Air & 12.7 & 3 & 6.0 \\
\hline 2402 & 2.02 & .36 & .14 & .12 & .05 & .34 & .07 & .41 & 200 & 6.0 & Arg & 12.7 & 3 & 6.0 \\
\hline \multicolumn{15}{|c|}{ DOUBLE REF A CLEAR-M IG } \\
\hline 2403 & 2.86 & .50 & .22 & .19 & .09 & .27 & .13 & .31 & 201 & 6.0 & Air & 6.3 & 3 & 6.0 \\
\hline 2404 & 2.35 & .41 & .20 & .17 & .09 & .27 & .13 & .31 & 201 & 6.0 & Air & 12.7 & 3 & 0 \\
\hline 2405 & 2.13 & .38 & .20 & .17 & .09 & .27 & .13 & .31 & 201 & 6.0 & Arg & 12.7 & 3 & .0 \\
\hline
\end{tabular}


Index to the Window Library (continued)

G-T-C U-SI U-IP $\quad$ SC $\quad$ SHGC Tsol Risol Tvis Rfvis ID $^{\text {LAY1 }}$ WID GAS WID ID WID

DOUBLE REF A CLEAR-H IG

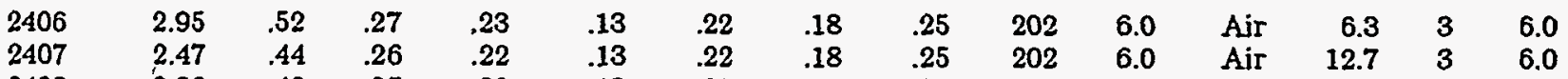

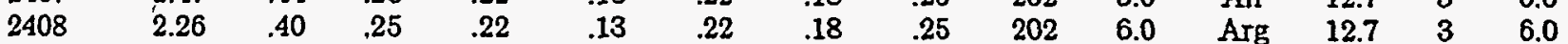

DOUBLE REF A TINT-L IG

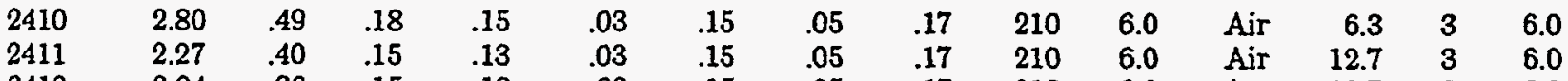

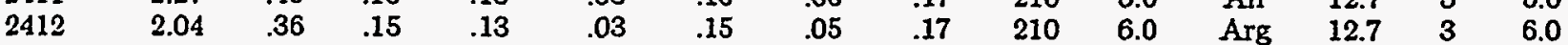

DOUBLE REF A TINT-M IG

$\begin{array}{lllllllllllllll}2413 & 2.86 & .50 & .20 & .17 & .05 & .13 & .08 & .14 & 211 & 6.0 & \text { Air } & 6.3 & 3 & 6.0\end{array}$

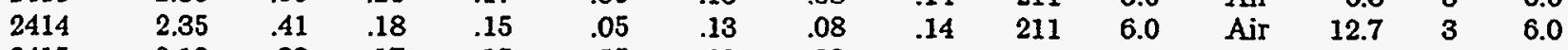

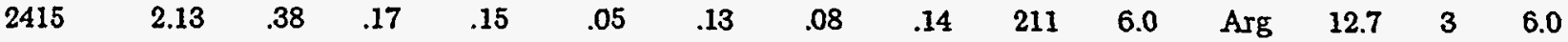

DOUBLE REF A TINT-H IG

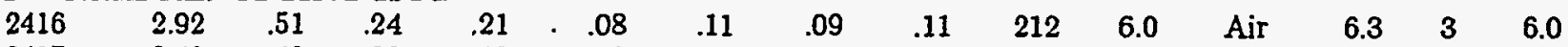

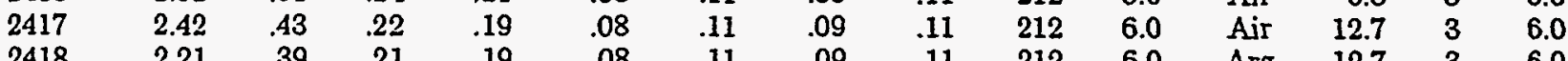

DOUBLE REF B CLR-L IG

\begin{tabular}{|c|c|c|c|c|c|c|c|c|c|c|c|c|c|}
\hline 420 & 2.96 & .52 & .27 & .23 & .12 & .22 & .18 & .23 & 220 & 6.0 & Air & 6.3 & 3 \\
\hline 242 & 2.48 & .44 & .25 & .22 & .12 & .22 & .18 & .23 & 220 & 6.0 & Air & 12.7 & 3 \\
\hline 2422 & 2.27 & .40 & .25 & .21 & .12 & .22 & .18 & .23 & 220 & 6.0 & Arg & 12.7 & 3 \\
\hline
\end{tabular}

DOUBLE REF B CLR-H IG

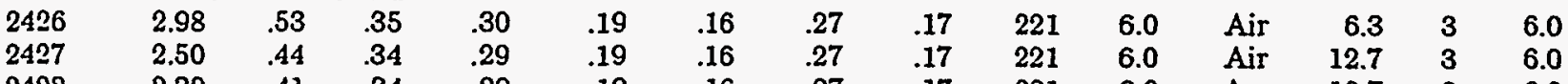

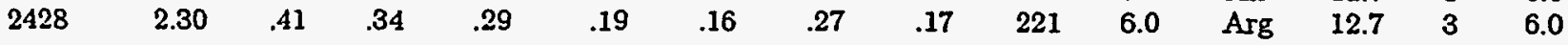

DOUBLE REF B TINT-L IG

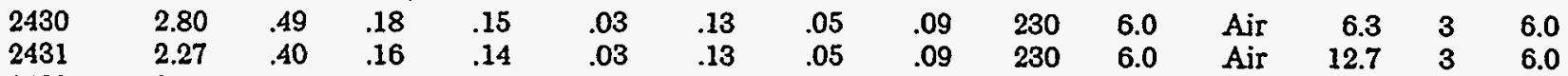

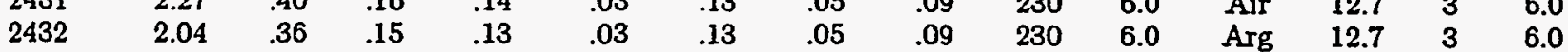

DOUBLE REF B TINT-M IG

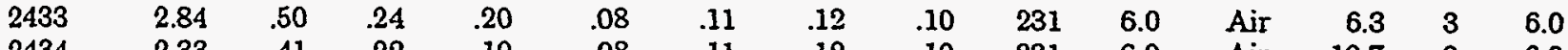

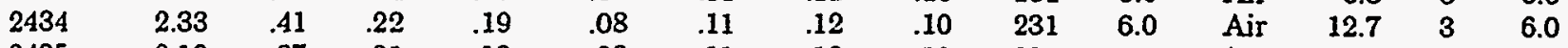

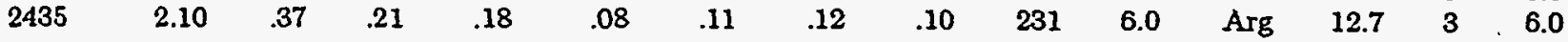

DOUBLE REF B TINT-H IG

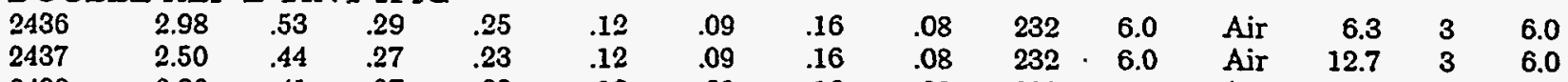

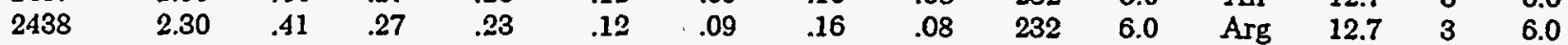

DOUBLE REF C CLEAR-L IG

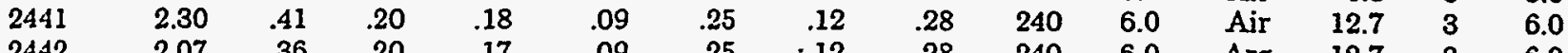

DOUBLE REF C CLEAR-M IG

$\begin{array}{llllllllllllllll}2443 & 2.90 & .51 & .28 & .24 & .14 & .20 & .17 & .21 & 241 & 6.0 & \text { Air } & 6.3 & 3 & 6.0\end{array}$

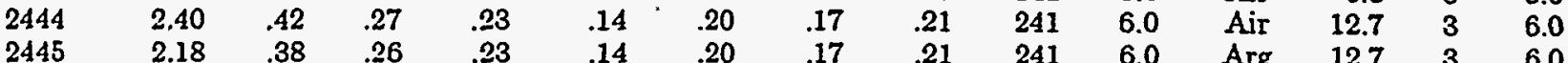


Index to the Window Library (continued)

\begin{tabular}{|c|c|c|c|c|c|c|c|c|c|c|c|c|c|c|}
\hline \multirow[b]{2}{*}{$G-T-C$} & \multirow[b]{2}{*}{ U-SI } & \multirow[b]{2}{*}{ U-IP } & \multirow[b]{2}{*}{$\mathrm{SC}$} & \multirow[b]{2}{*}{ SHGC } & \multirow[b]{2}{*}{ Tsol } & \multirow[b]{2}{*}{ Risol } & \multirow[b]{2}{*}{ Tris } & \multirow[b]{2}{*}{ Rfvis } & \multicolumn{2}{|c|}{ LAY 1} & \multicolumn{2}{|c|}{ GAP1 } & \multicolumn{2}{|c|}{ LAY2 } \\
\hline & & & & & & & & & ID & WID & GAS & WID & $\mathrm{ID}$ & W \\
\hline OU & & & & & & & & & & & & & & \\
\hline 2446 & 2.94 & .52 & .32 & .27 & .16 & .16 & .20 & .17 & 242 & 6.0 & Air & 6.3 & 3 & \\
\hline 2447 & 2.45 & .43 & .30 & .26 & .16 & .16 & .20 & .17 & 242 & 6.0 & Air & 12.7 & 3 & \\
\hline 2448 & 2.23 & .39 & .30 & .26 & .16 & .16 & .20 & .17 & 242 & 6.0 & Arg & 12.7 & 3 & 0 \\
\hline
\end{tabular}

DOUBLE REF C TINT-L IG

\begin{tabular}{|c|c|c|c|c|c|c|c|c|c|c|c|c|c|c|}
\hline 450 & 2.82 & .50 & .21 & .18 & .06 & .13 & .07 & .13 & 250 & 6.0 & Air & 6.3 & 3 & 6.0 \\
\hline 451 & 2.30 & .41 & .19 & .16 & .06 & .13 & .07 & .13 & 250 & 6.0 & Air & 12.7 & 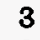 & 6.0 \\
\hline 2450 & 2.07 & .36 & .18 & .15 & .06 & .13 & .07 & .13 & 250 & 6.0 & Arg & 12.7 & 3 & 0 \\
\hline
\end{tabular}

DOUBLE REF C TINT-M IG

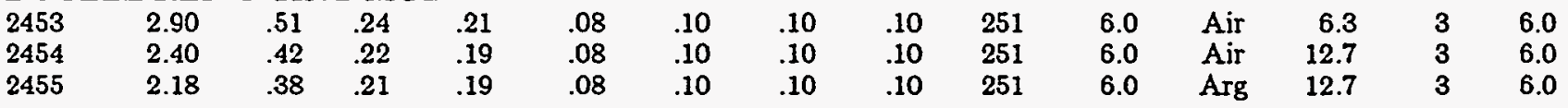

DOUBLE REF C TINT-H IG

\begin{tabular}{|c|c|c|c|c|c|c|c|c|c|c|c|c|}
\hline 2.94 & .52 & .26 & .23 & .10 & .09 & .12 & .09 & 252 & 6.0 & Air & 6.3 & 3 \\
\hline 2.45 & .43 & .24 & .21 & .10 & .09 & .12 & .09 & 252 & 6.0 & Air & 12.7 & 3 \\
\hline 2.23 & .39 & .24 & .20 & .10 & .09 & .12 & .09 & 252 & 6.0 & Arg & 12.7 & 3 \\
\hline
\end{tabular}

DOUBLE REF D CLEAR IG

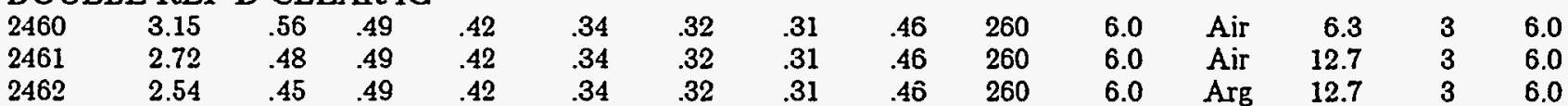

DOUBLE REF D TINT IG

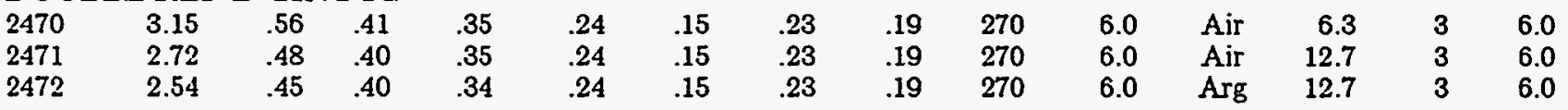

DOUBLE LOW-E $(e 3=.4)$ CLEAR IG

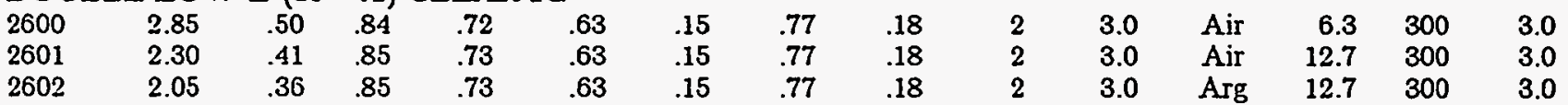

DOUBLE LOW-E (e3=.2) CLEAR IG

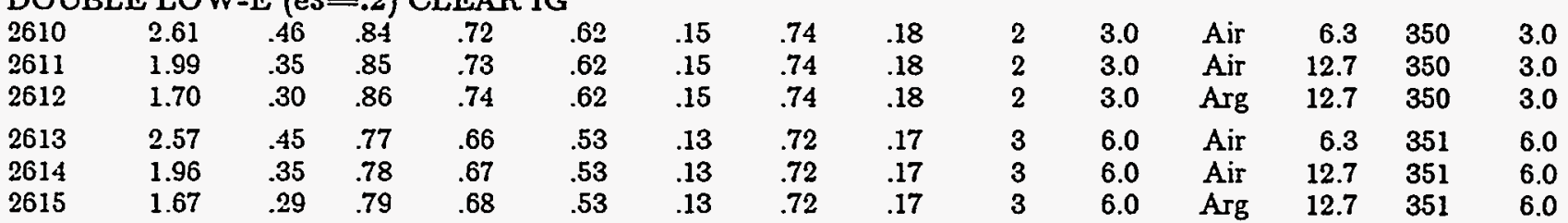

DOUBLE LOW-E (e2=.1) CLEAR IG

\begin{tabular}{|c|c|c|c|c|c|c|c|c|c|c|c|c|c|c|}
\hline $\begin{array}{l}2630 \\
2631 \\
2632\end{array}$ & $\begin{array}{l}2.47 \\
1.81 \\
1.48\end{array}$ & $\begin{array}{l}.44 \\
.32 \\
.26\end{array}$ & $\begin{array}{l}.69 \\
.69 \\
.69\end{array}$ & $\begin{array}{l}.60 \\
.60 \\
.59\end{array}$ & $\begin{array}{l}.54 \\
.54 \\
.54\end{array}$ & $\begin{array}{l}.22 \\
.22 \\
.22\end{array}$ & $\begin{array}{r}.77 \\
.77 \\
.77\end{array}$ & $\begin{array}{l}.14 \\
.14 \\
.14\end{array}$ & $\begin{array}{l}400 \\
400 \\
400\end{array}$ & $\begin{array}{l}3.0 \\
3.0 \\
3.0\end{array}$ & $\begin{array}{l}\text { Air } \\
\text { Air } \\
\text { Arg }\end{array}$ & $\begin{array}{r}6.3 \\
12.7 \\
12.7\end{array}$ & $\begin{array}{l}2 \\
2 \\
2\end{array}$ & $\begin{array}{l}3.0 \\
3.0 \\
3.0\end{array}$ \\
\hline $\begin{array}{l}2633 \\
2634 \\
2635\end{array}$ & $\begin{array}{l}2.43 \\
1.78 \\
1.46\end{array}$ & $\begin{array}{l}.43 \\
.31 \\
.26\end{array}$ & $\begin{array}{l}.65 \\
.65 \\
.66\end{array}$ & $\begin{array}{l}.56 \\
.56 \\
.56\end{array}$ & $\begin{array}{l}.47 \\
.47 \\
.47\end{array}$ & $\begin{array}{l}.20 \\
.20 \\
.20\end{array}$ & $\begin{array}{l}.75 \\
.75 \\
.75\end{array}$ & $\begin{array}{l}.11 \\
.11 \\
.11\end{array}$ & $\begin{array}{l}401 \\
401 \\
401\end{array}$ & $\begin{array}{l}6.0 \\
6.0 \\
6.0\end{array}$ & $\begin{array}{l}\text { Air } \\
\text { Air } \\
\text { Arg }\end{array}$ & $\begin{array}{r}6.3 \\
12.7 \\
12.7\end{array}$ & $\begin{array}{l}3 \\
3 \\
3\end{array}$ & 6.0 \\
\hline
\end{tabular}


Index to the Window Library (continued)

\begin{tabular}{lcccccccccccccc} 
G-T-C & U-SI & U-IP & SC & SHGC & Tsol & Rfsol & Tvis & Rfvis & D & WID & GAS & WID & LD & WID \\
\hline DOUBLE LOW-E (e2 & $=.1)$ & TINT IG & & & & & & & & & & \\
2636 & 2.43 & .43 & .45 & .39 & .28 & .10 & .44 & .05 & 451 & 6.0 & Air & 6.3 & 3 & 6.0 \\
2637 & 1.78 & .31 & .43 & .37 & .28 & .10 & .44 & .05 & 451 & 6.0 & Air & 12.7 & 3 & 6.0 \\
2638 & 1.46 & .26 & .43 & .37 & .28 & .10 & .44 & .05 & 451 & 6.0 & Arg & 12.7 & 3 & 6.0
\end{tabular}

DOUBLE LOW-E (e3=.1) CLEAR IG

$\begin{array}{rrrrrrrrrrrrrrr}2640 & 2.47 & .44 & .74 & .63 & .54 & .23 & .77 & .13 & 2 & 3.0 & \text { Air } & 6.3 & 400 & 3.0 \\ 2641 & 1.81 & .32 & .75 & .64 & .54 & .23 & .77 & .13 & 2 & 3.0 & \text { Air } & 12.7 & 400 & 3.0 \\ 2642 & 1.48 & .26 & .75 & .65 & .54 & .23 & .77 & .13 & 2 & 3.0 & \text { Arg } & 12.7 & 400 & 3.0\end{array}$

DOUBLE LOW-E (e2=.04) CLEAR IG

$\begin{array}{lllllllllllllll}2660 & 2.38 & .42 & .51 & .44 & .39 & .36 & .70 & .12 & 500 & 3.0 & \text { Air } & 6.3 & 2 & 3.0 \\ 2661 & 1.68 & .30 & .51 & .44 & .39 & .36 & .70 & .12 & 500 & 3.0 & \text { Air } & 12.7 & 2 & 3.0 \\ 2662 & 1.34 & .24 & .50 & .43 & .39 & .36 & .70 & .12 & 500 & 3.0 & \text { Arg } & 12.7 & 2 & 3.0\end{array}$

DOUBLE LOW-E $(\mathrm{e} 2=.04)$ CLEAR IG

$\begin{array}{rrrrrrrrrrrrrrr}2663 & 2.41 & .42 & .49 & .42 & .34 & .31 & .68 & .12 & 501 & 6.0 & \text { Air } & 6.3 & 3 & 6.0 \\ 2664 & 1.67 & .29 & .48 & .42 & .34 & .31 & .68 & .12 & 501 & 6.0 & \text { Air } & 12.7 & 3 & 6.0 \\ 2665 & 1.32 & .23 & .48 & .42 & .34 & .31 & .68 & .12 & 501 & 6.0 & \text { Arg } & 12.7 & 3 & 6.0\end{array}$

DOUBLE LOW-E (e2=.04) TINT IG

$\begin{array}{lllllllllllllll}2666 & 2.41 & .42 & .35 & .31 & .21 & .14 & .41 & .08 & 550 & 6.0 & \text { Air } & 6.3 & 3 & 6.0 \\ 2667 & 1.67 & .29 & .33 & .29 & .21 & .14 & .41 & .08 & 550 & 6.0 & \text { Air } & 12.7 & 3 & 6.0 \\ 2668 & 1.32 & .23 & .32 & .28 & .21 & .14 & .41 & .08 & 550 & 6.0 & \text { Arg } & 12.7 & 3 & 6.0\end{array}$

DOUBLE ELECTROCHROMIC ABSORBING IG BLEACHED/COLORED AIR

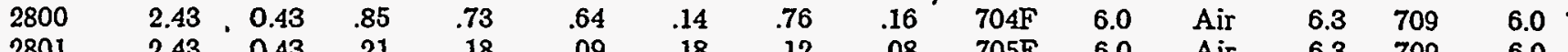

DOUBLE ELECTROCHROMIC ABSORBING IG BLEACFED/COLORED AIR

$\begin{array}{lllllllllllllll}2802 & 1.78 & 0.31 & .86 & .74 & .64 & .14 & .76 & .16 & 704 \mathrm{~F} & 6.0 & \text { Air } & 12.7 & 709 & 6.0\end{array}$

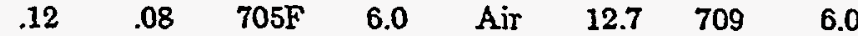

DOUBLE ELECTROCHROMIC ABSORBING IG BLEACHED/COLORED ARGON

$\begin{array}{lllllllllllllll}2804 & 1.49 & 0.26 & .86 & .74 & .64 & .14 & .76 & .16 & 704 \mathrm{~F} & 6.0 & \text { Arg } & 12.7 & 709 & 6.0 \\ 2805 & 1.49 & 0.26 & 18 & 15 & .09 & .18 & .12 & .08 & 705 \mathrm{~F} & 6.0 & \text { Arg } & 12.7 & 709 & 6.0\end{array}$

DOUBLE ELECTROCHROMIC REFLECTING IG BLEACHED/COLORED AIR

$\begin{array}{lllllllllllllll}2820 & 2.43 & 0.43 & .73 & .63 & .55 & .21 & .73 & .17 & 706 \mathrm{~F} & 6.0 & \text { Air } & 6.3 & 709 & 6.0 \\ 2821 & 2.43 & 0.43 & .20 & 17 & 09 & .22 & .4 & .08 & 707 \mathrm{~F} & 6.0 & \text { Air } & 6.3 & 709 & 6.0\end{array}$

DOUBLE ELECTROCHROMIC REFLECTING IG BLEACHED/COLORED AIR

$\begin{array}{lllllllllllllll}2822 & 1.78 & 0.31 & .74 & .64 & .55 & .21 & .73 & .17 & 706 \mathrm{~F} & 6.0 & \text { Air } & 12.7 & 709 & 6.0 \\ 2823 & 1.78 & 0.31 & 17 & .15 & .09 & .22 & 14 & .08 & 707 \mathrm{~F} & 6.0 & \text { Air } & 127 & 709 & 6.0\end{array}$

DOUBLE ELECTROCHROMIC REFLECTING IG BLEACHED/COLORED ARGON

$\begin{array}{lllllllllllllll}2824 & 1.49 & 0.26 & .74 & .64 & .55 & .21 & .73 & .17 & 706 \mathrm{~F} & 6.0 & \mathrm{Arg} & 12.7 & 709 & 6.0 \\ 2825 & 1.49 & 0.26 & .16 & .15 & .09 & .2 & & \end{array}$

$\begin{array}{lllll}6.0 & \text { Arg } & 12.7 & 709 & 6.0\end{array}$

DOUBLE LOW-E (e2=.029) ELECTROCHROMIC ABS IG BLEACHED/COLORED AIR

$\begin{array}{lllllllllllllll}2840 & 2.33 & 0.41 & .51 & .44 & .34 & .33 & .66 & .14 & 704 \mathrm{~F} & 6.0 & \text { Air } & 6.3 & 708 \mathrm{~F} & 5.7\end{array}$

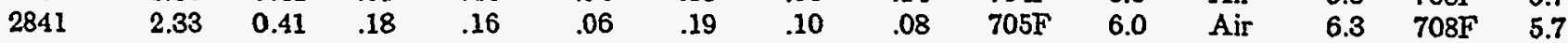

DOUBLE LOW-E (e2=.029) ELECTROCHROMIC ABS IG BLEACHED/COLORED AIR

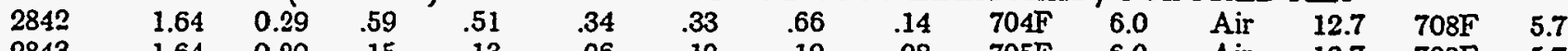

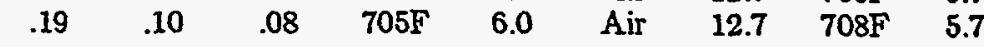

DOUBLE LOW-E (e2=.029) ELECTROCHROMIC ABS IG BLEACHED/COLORED ARGON

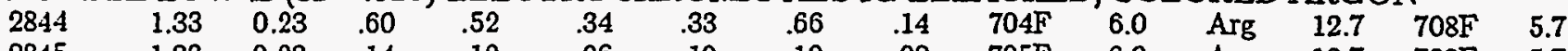

$\begin{array}{lllllllllllllll}2845 & 1.33 & 0.23 & .14 & .12 & .06 & .19 & .10 & .08 & 705 \mathrm{~F} & 6.0 & \text { Arg } & 12.7 & 708 \mathrm{~F} & 5.7\end{array}$ 
Index to the Window Library (continued)

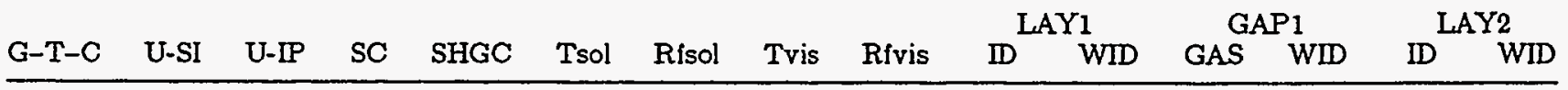

DOUBLE LOW-E (e2=.028) ELECTROCHROMIC REF IG BLEACHED/COLORED AIR

$\begin{array}{lllllllllllllll}2860 & 2.33 & 0.41 & .54 & .46 & .32 & .32 & .64 & .14 & 706 \mathrm{~F} & 6.0 & \text { Air } & 6.3 & 708 \mathrm{~F} & 5.7\end{array}$

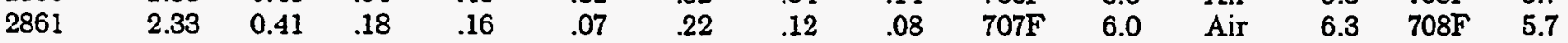

DOUBLE LOW-E (e2=.029) ELECTROCHROMIC REF IG BLEACHED/COLORED AIR

$\begin{array}{lllllllllllllll}2862 & 1.64 & 0.29 & .55 & .47 & .32 & .32 & .64 & .14 & 706 \mathrm{~F} & 6.0 & \text { Air } & 12.7 & 708 \mathrm{~F} & 5.7 \\ 2863 & 1.64 & 0.29 & .16 & .14 & .07 & .22 & .12 & .08 & 707 \mathrm{~F} & 6.0 & \text { Air } & 12.7 & 708 \mathrm{~F} & 5.7\end{array}$

DOUBLE LOW-E (e2=.028) ELECTROCHROMIC REF IG BLEACHED/COLORED ARGON

$\begin{array}{lllllllllllllll}2864 & 1.33 & 0.23 & .56 & .48 & .32 & .32 & .64 & .14 & 706 \mathrm{~F} & 6.0 & \text { Arg } & 12.7 & 708 \mathrm{~F} & 5.7\end{array}$

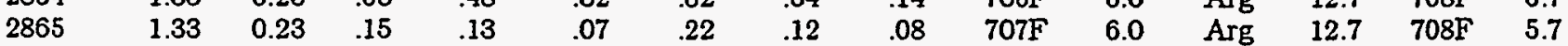


Index to the Window Library (continued)

G-T-C U-SI U-IP SC SHGC Tsol Rfsol Tvis Rfvis ID $\stackrel{\text { LAY1 }}{\text { WID GAP1 }}$ WID ID WID GAS WID

TRIPLE OLEAR IG

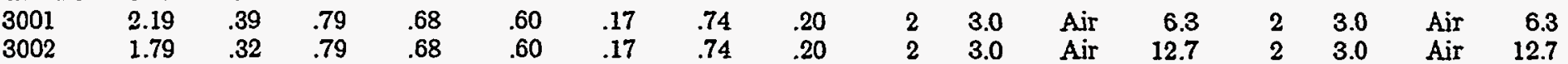

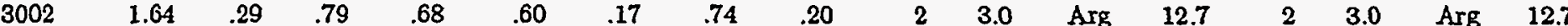

TRIPLE LOW-E (e5=.1) CLEAR IG

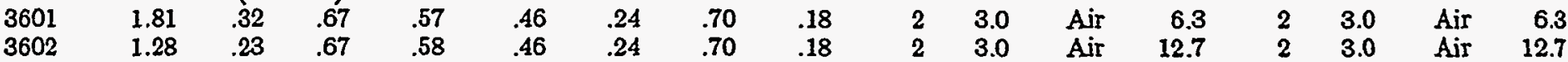

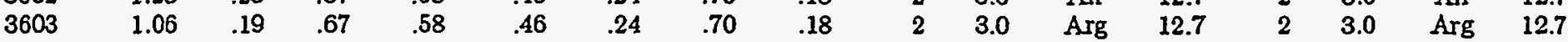

TRIPLE LOW-E (e2=e5 $=.1)$ CLEAR IG

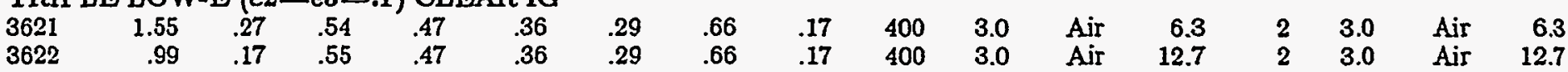

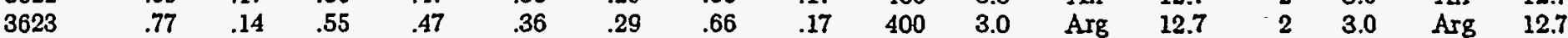

TRIPLE LOW-E FILM (88) CLEAR IG

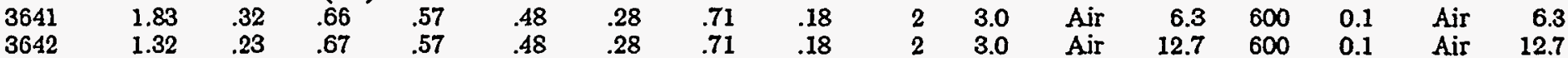

TRIPLE LOW-E FILM (77) CLEAR IG

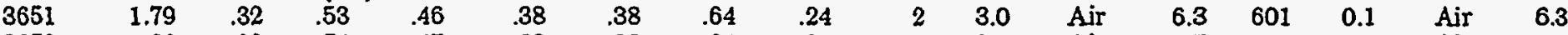

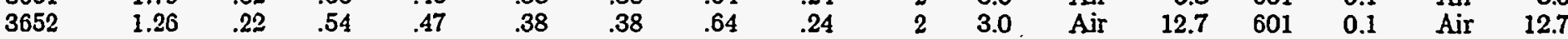

TRIPLE LOW-E FILM (8B) CLEAR IG

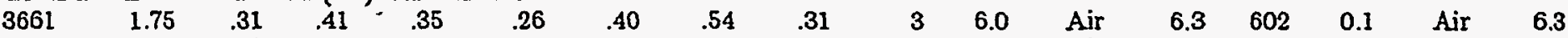

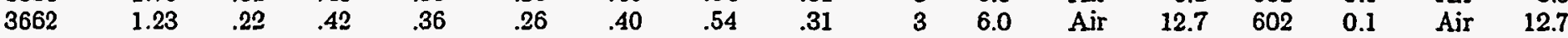

TRIPLE LOW-E FILM (08) TINT IG

$\begin{array}{llllllllllllllllllll}3663 & 1.75 & .31 & .30 & .26 & .16 & .18 & .32 & .14 & 6 & 6.0 & \text { Air } & 6.3 & 602 & 0.1 & \text { Air } & \cdot 6.3\end{array}$

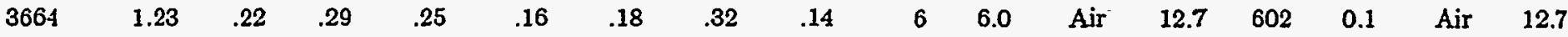

TRIPLE LOW-E FILM (55) CLEAR IG

$\begin{array}{lllllllllllllllll}3671 & 1.74 & .31 & .35 & .30 & .21 & .44 & .45 & .37 & 3 & 6.0 & \text { Air } & 6.3 & 603 & 0.1 & \text { Air } & 6.3\end{array}$

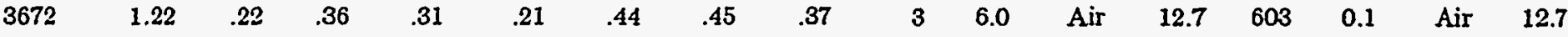

TRIPLE LOW-E FILM (55) TINT IG

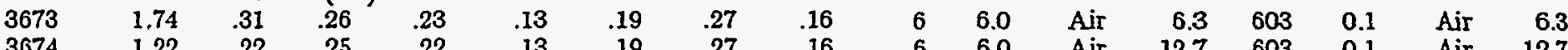

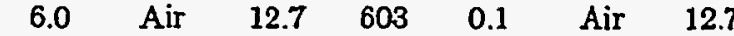

TRIPLE LOW-E FILM (44) TINT IG

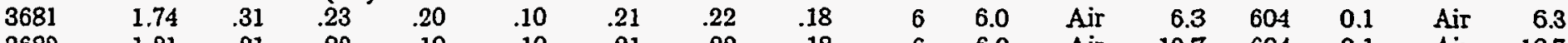

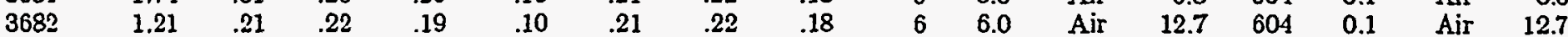

$\begin{array}{lllllllllllllllll}\text { TRIPLE LOW-E FILM (33) } & \text { TINT IG } & & & & & & & & & \\ 3691 & 1.74 & .31 & .19 & .16 & .07 & .23 & .17 & .23 & 6 & 6.0 & \text { Air } & 6.3 & 605 & 0.1 & \text { Air } & 6.3\end{array}$

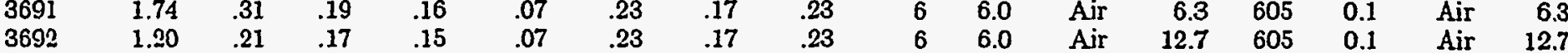

$\begin{array}{lllll}\text { LAY1 GAP1 } & \text { LAY2 } & \text { GAP2 }\end{array}$ G-T-C U-SI U-IP SC SHGC Tsol Risol Tvis Rivis ID WID GAS WID ID WID GAS WID QUAD LOW-E GLAZING / LOW-E FILMS CLEAR IG

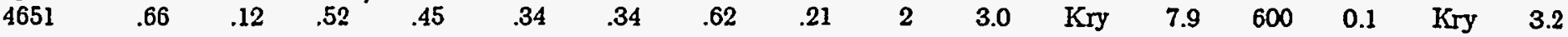

\begin{tabular}{cccccc}
\multicolumn{2}{c}{ LAY3 } & \multicolumn{2}{c}{ GAP3 } & \multicolumn{2}{c}{ LAY4 } \\
ID & WID & GAS & WID & ID & WID \\
\hline 600 & 0.1 & Kry & 7.9 & 2 & 3.0
\end{tabular}


Geographical Data for the 50 Largest U.S. Cities

\begin{tabular}{|c|c|c|c|c|}
\hline State & City & Lat. & Long. & Time Zone \\
\hline Arizona & $\begin{array}{l}\text { Phoenix } \\
\text { Tucson }\end{array}$ & $\begin{array}{l}33.45 \\
32.13 \\
\end{array}$ & $\begin{array}{l}112.07 \\
110.58 \\
\end{array}$ & $\begin{array}{l}7 \\
7 \\
\end{array}$ \\
\hline California & $\begin{array}{l}\text { Fresno } \\
\text { Long Beach } \\
\text { Los Angeles } \\
\text { Oakland } \\
\text { Sacramento } \\
\text { San Diego } \\
\text { San Francisco } \\
\text { San Jose }\end{array}$ & $\begin{array}{l}36.43 \\
33.78 \\
34.07 \\
37.82 \\
38.35 \\
32.72 \\
37.78 \\
37.33 \\
\end{array}$ & $\begin{array}{l}119.47 \\
118.18 \\
118.25 \\
122.27 \\
121.29 \\
117.15 \\
122.42 \\
121.88 \\
\end{array}$ & $\begin{array}{l}8 \\
8 \\
8 \\
8 \\
8 \\
8 \\
8 \\
8\end{array}$ \\
\hline Colorado & Denver & 39.73 & 104.98 & 7 \\
\hline Florida & $\begin{array}{l}\text { Jacksonville } \\
\text { Miami }\end{array}$ & $\begin{array}{l}30.33 \\
25.78 \\
\end{array}$ & $\begin{array}{l}81.65 \\
80.18 \\
\end{array}$ & $\begin{array}{l}5 \\
5 \\
\end{array}$ \\
\hline Georgia & Atlanta & 33.75 & 84.38 & 5 \\
\hline Hawaii & Honolulu & 21.32 & 157.87 & 10 \\
\hline Illinois & Chicago & 41.88 & 87.63 & 6 \\
\hline Indiana & Indianapolis & 39.77 & 86.15 & 5 \\
\hline Louisiana & New Orleans & 29.97 & 90.07 & 6 \\
\hline Maryland & Baltimore & 39.28 & 76.62 & 5 \\
\hline Massachusetts & Boston & 42.37 & 71.07 & 5 \\
\hline Michigan & Detroit & 42.33 & 83.00 & 5 \\
\hline Minnesota & Minneapolis & 44.98 & 93.27 & 6 \\
\hline Missouri & $\begin{array}{l}\text { Kansas City } \\
\text { Saint Louis }\end{array}$ & $\begin{array}{l}39.10 \\
38.62 \\
\end{array}$ & $\begin{array}{l}94.58 \\
90.20 \\
\end{array}$ & $\begin{array}{l}6 \\
6 \\
\end{array}$ \\
\hline Nebraska & Omaha & 41.28 & 96.02 & 6 \\
\hline New Mexico & Albuquerque & 35.05 & 106.39 & 6 \\
\hline New York & $\begin{array}{l}\text { Buffalo } \\
\text { New York } \\
\end{array}$ & $\begin{array}{l}42.88 \\
40.72 \\
\end{array}$ & $\begin{array}{l}78.88 \\
74.00 \\
\end{array}$ & $\begin{array}{l}5 \\
5 \\
\end{array}$ \\
\hline North Carolina & Charlotte & 35.13 & 80.5 & 5 \\
\hline Ohio & $\begin{array}{l}\text { Cincinnati } \\
\text { Cleveland } \\
\text { Columbus } \\
\text { Toledo } \\
\end{array}$ & $\begin{array}{l}39.10 \\
41.50 \\
39.97 \\
41.65 \\
\end{array}$ & $\begin{array}{l}84.52 \\
81.70 \\
83.00 \\
83.55 \\
\end{array}$ & $\begin{array}{l}5 \\
5 \\
5 \\
5 \\
\end{array}$ \\
\hline Oklahoma & $\begin{array}{l}\text { Oklahoma City } \\
\text { Tulsa }\end{array}$ & $\begin{array}{l}35.50 \\
36.17 \\
\end{array}$ & $\begin{array}{l}97.50 \\
95.92 \\
\end{array}$ & $\begin{array}{l}6 \\
6 \\
\end{array}$ \\
\hline
\end{tabular}




\begin{tabular}{lllll} 
Oregon & Portland & 45.53 & 122.62 & 8 \\
\hline \multirow{2}{*}{ Pennsylvania } & Philadelphia & 39.95 & 75.17 & 5 \\
& Pittsburgh & 40.43 & 80.02 & 5 \\
\hline \multirow{2}{*}{ Tennessee } & Memphis & 35.13 & 90.05 & 6 \\
& Nashville & 36.17 & 86.78 & 6 \\
\hline \multirow{2}{*}{ Texas } & Austin & 30.16 & 97.44 & 6 \\
& Dallas & 32.78 & 96.82 & 6 \\
& El Paso & 31.75 & 106.48 & 7 \\
\hline Virginia & Fort Worth & 32.75 & 97.30 & 6 \\
\hline Washington & Houston & 29.77 & 95.37 & 6 \\
\hline Wisconsin & San Antonio & 29.42 & 98.50 & 5 \\
\hline D.C. & Virginia Beach & 36.5 & 75.58 & 8 \\
\hline
\end{tabular}




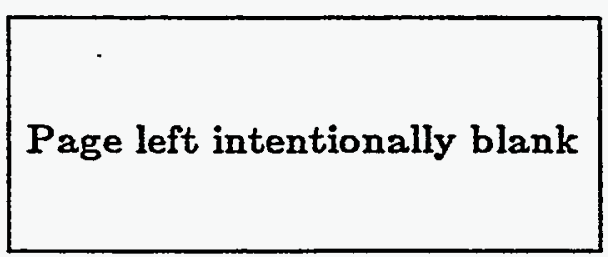

$-134 . a-$ 


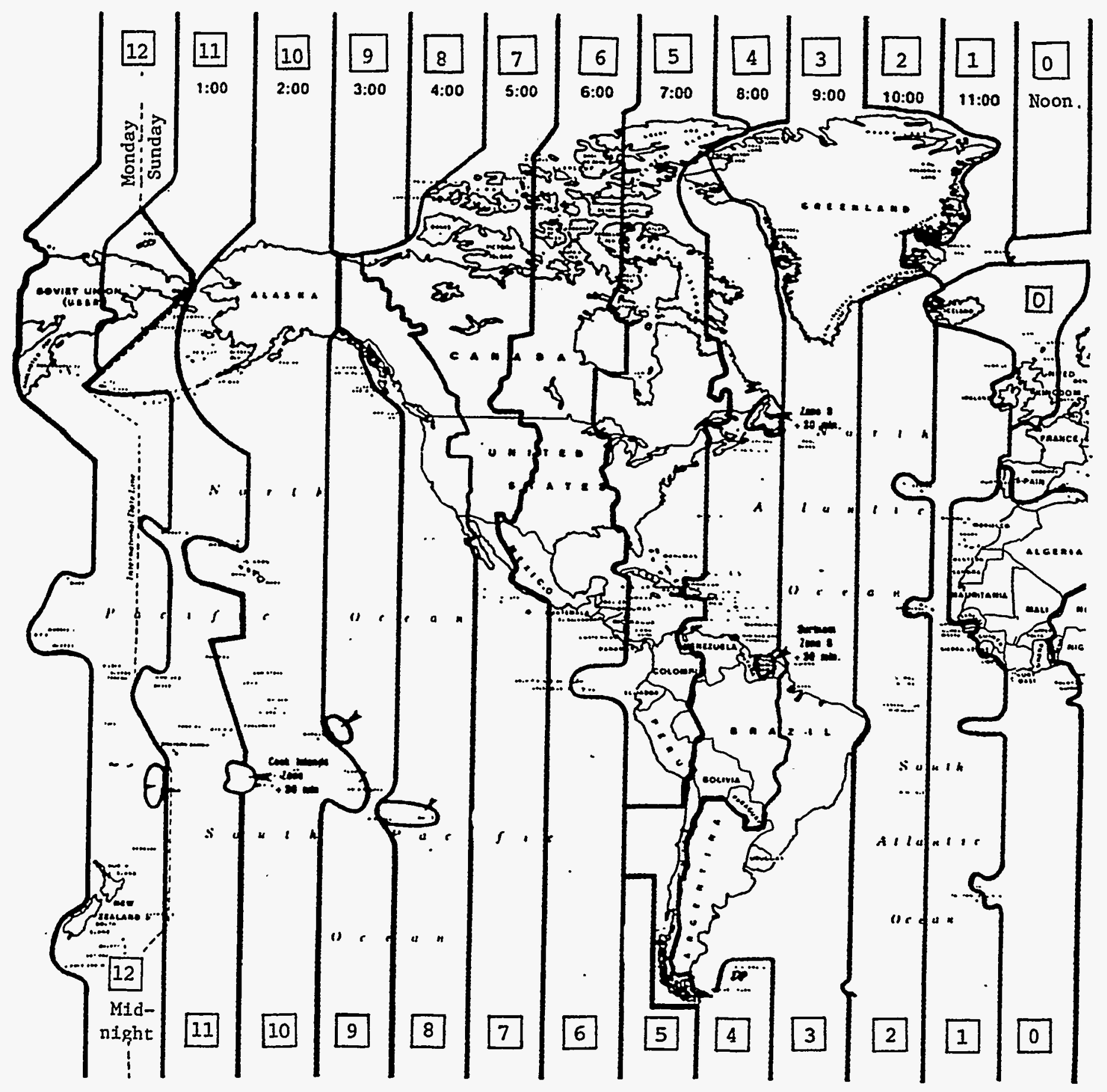




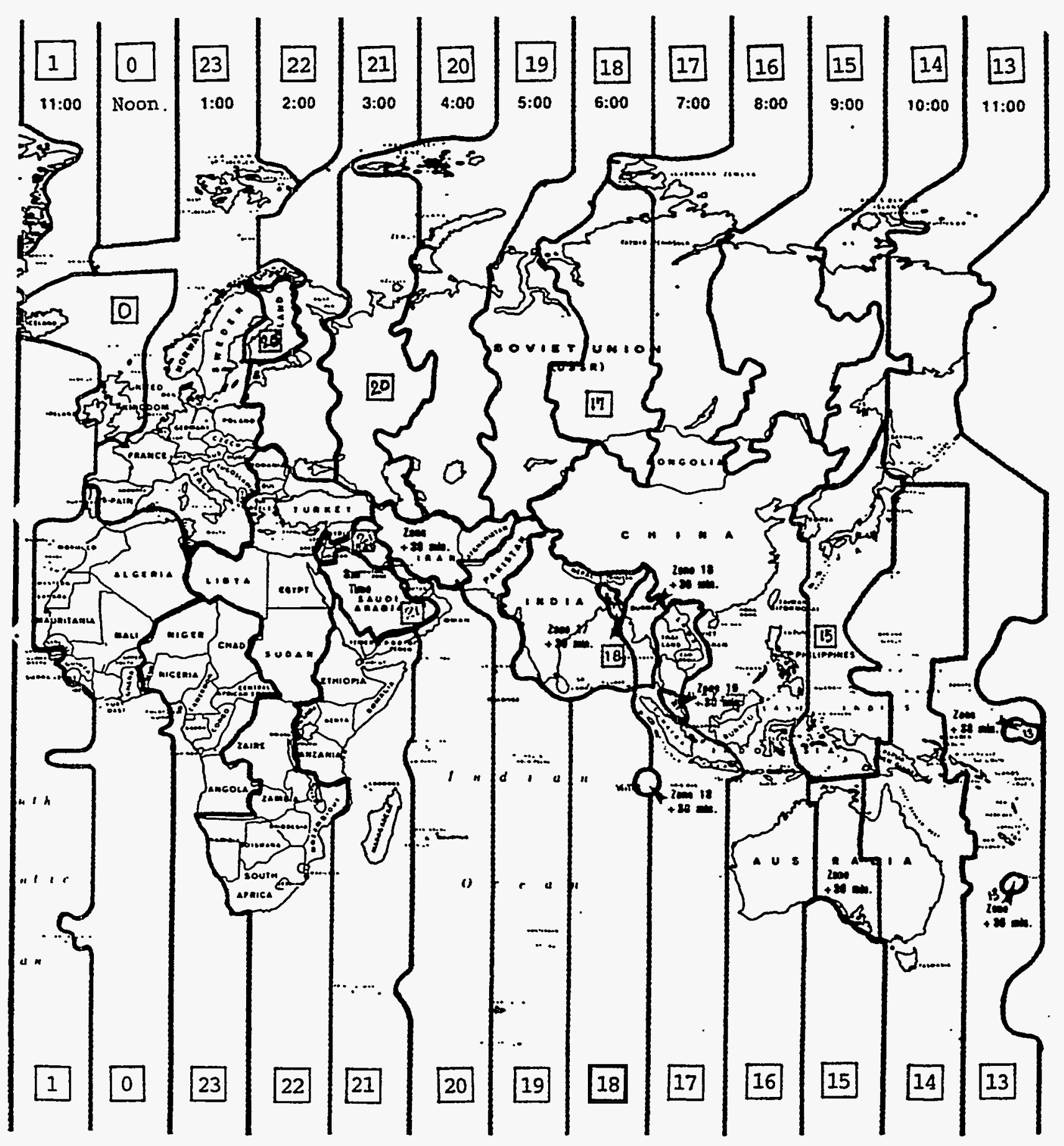




\begin{tabular}{|c|c|c|c|c|c|c|c|c|c|c|c|c|c|c|c|c|c|}
\hline \multicolumn{18}{|c|}{$I N D E X$} \\
\hline 1778 & 8 & 1801 & 5 & 1826 & 1 & 1851 & 4 & 1876 & 14 & 1801 & 3 & 1926 & 6 & 1951 & 2 & 1976 & 12 \\
\hline 1777 & 4 & 1802 & 6 & 1827 & 2 & 1852 & 12 & 1877 & 2 & 1902 & 4 & 1927 & 7 & 1952 & 10 & 1877 & 7 \\
\hline 1778 & 5 & 1803 & 7 & 1828 & 10 & 1853 & 7 & 1878 & 3 & 1903 & 5 & 1928 & 8 & 1953 & 5 & 1978 & 1 \\
\hline 1778 & 6 & 1804 & 8 & 1829 & 5 & 1854 & 1 & 1879 & 4 & 1804 & 13 & 1929 & 3 & 1954 & 6 & 1978 & 2 \\
\hline 1780 & 14 & 1805 & 3 & 1830 & 6 & 1855 & 2 & 1880 & 12 & 1905 & 1 & 1930 & 4 & 1955 & 7 & 1980 & 10 \\
\hline 1781 & 2 & 1806 & 4 & 1831 & 7 & 1856 & 10 & 1881 & 7 & 1906 & 2 & 1931 & 5 & 1956 & 8 & 1881 & 5 \\
\hline 1782 & 3 & 1807 & 5 & 1832 & 8 & 1857 & 5 & 1882 & 1 & 1907 & 3 & 1932 & 13 & 1857 & 3 & 1882 & 6 \\
\hline 1783 & 4 & 1808 & 13 & 1833 & 3 & 1858 & 6 & 1883 & 2 & 1908 & 11 & 1933 & 1 & 1958 & 4 & 1883 & 7 \\
\hline 1784 & 12 & 1809 & 1 & 1834 & 4 & 1859 & 7 & 1884 & 10 & 1909 & 6 & 1934 & 2 & 1959 & 5 & 1884 & 8 \\
\hline 1785 & 7 & 1810 & 2 & 1835 & 5 & 1860 & 8 & 1886 & 5 & 1910 & 7 & 1935 & 3 & 1960 & 13 & 1885 & 3 \\
\hline 1786 & 1 & 1811 & 3 & 1836 & 13 & 1861 & 3 & 1886 & 6 & 1911 & 1 & 1936 & 11 & 1861 & 1 & 1886 & 4 \\
\hline 1787 & 2 & 1812 & 11 & 1837 & 1 & 1862 & 4 & 1887 & 7 & 1912 & $\theta$ & 1937 & 6 & 1962 & 2 & 1987 & 5 \\
\hline 1788 & 10 & 1813 & 6 & 1838 & 2 & 1863 & 5 & 1888 & 8 & 1913 & 4 & 1838 & 7 & 1963 & 3 & 1988 & 13 \\
\hline 1789 & 5 & 1814 & 7 & 1839 & 3 & 1864 & 13 & 1889 & 3 & 1914 & 5 & 1939 & 1 & 1864 & 11 & 1989 & 1 \\
\hline 1790 & 6 & 1815 & 1 & 1840 & 11 & 1865 & 1 & 1890 & 4 & 1915 & 6 & 1940 & $\mathbf{9}$ & 1865 & 6 & 1990 & 2 \\
\hline 1791 & 7 & 1816 & 8 & 1841 & 6 & 1866 & 2 & 1891 & 5 & 1916 & 14 & 1941 & 4 & 1966 & 7 & 1981 & 3 \\
\hline 1782 & 8 & 1817 & 4 & 1842 & 7 & 1867 & 3 & 1892 & 13 & 1817 & 2 & 1842 & 5 & 1867 & 1 & 1992 & 11 \\
\hline 1793 & 3 & 1818 & 5 & 1843 & 1 & 1868 & 11 & 1893 & 1 & 1918 & 3 & 1943 & 6 & 1968 & 9 & 1893 & 6 \\
\hline 1784 & 4 & 1819 & 6 & 1844 & 9 & 1869 & 6 & 1894 & 2 & 1819 & 4 & 1844 & 14 & 1969 & 4 & 1894 & 7 \\
\hline 1795 & 5 & 1820 & 14 & 1845 & 4 & 1870 & 7 & 1895 & 3 & 1920 & 12 & 1945 & 2 & 1870 & 5 & 1895 & 1 \\
\hline 1796 & 13 & 1821 & 2 & 1846 & 5 & 1871 & 1 & 1886 & 11 & 1921 & 7 & 1946 & 3 & 1871 & 6 & 1996 & 9 \\
\hline 1797 & 1 & 1822 & 3 & 1847 & 6 & 1872 & 8 & 1897 & 6 & 1922 & 1 & 1847 & 4 & 1972 & 14 & 1997 & 4 \\
\hline 1798 & 2 & 1823 & 4 & 1848 & 14 & 1873 & 4 & 1898 & 7 & 1923 & 2 & 1948 & 12 & 1873 & 2 & 1898 & 5 \\
\hline 1709 & 3 & 1824 & 12 & 1849 & 2 & 1874 & 5 & 1899 & 1 & 1824 & 10 & 1949 & 7 & 1874 & 3 & 1998 & 6 \\
\hline 1800 & 4 & 1825 & 7 & 1850 & 3 & 1875 & 6 & 1900 & 2 & 1825 & 5 & 1950 & 1 & 1975 & 4 & 2000 & 14 \\
\hline
\end{tabular}
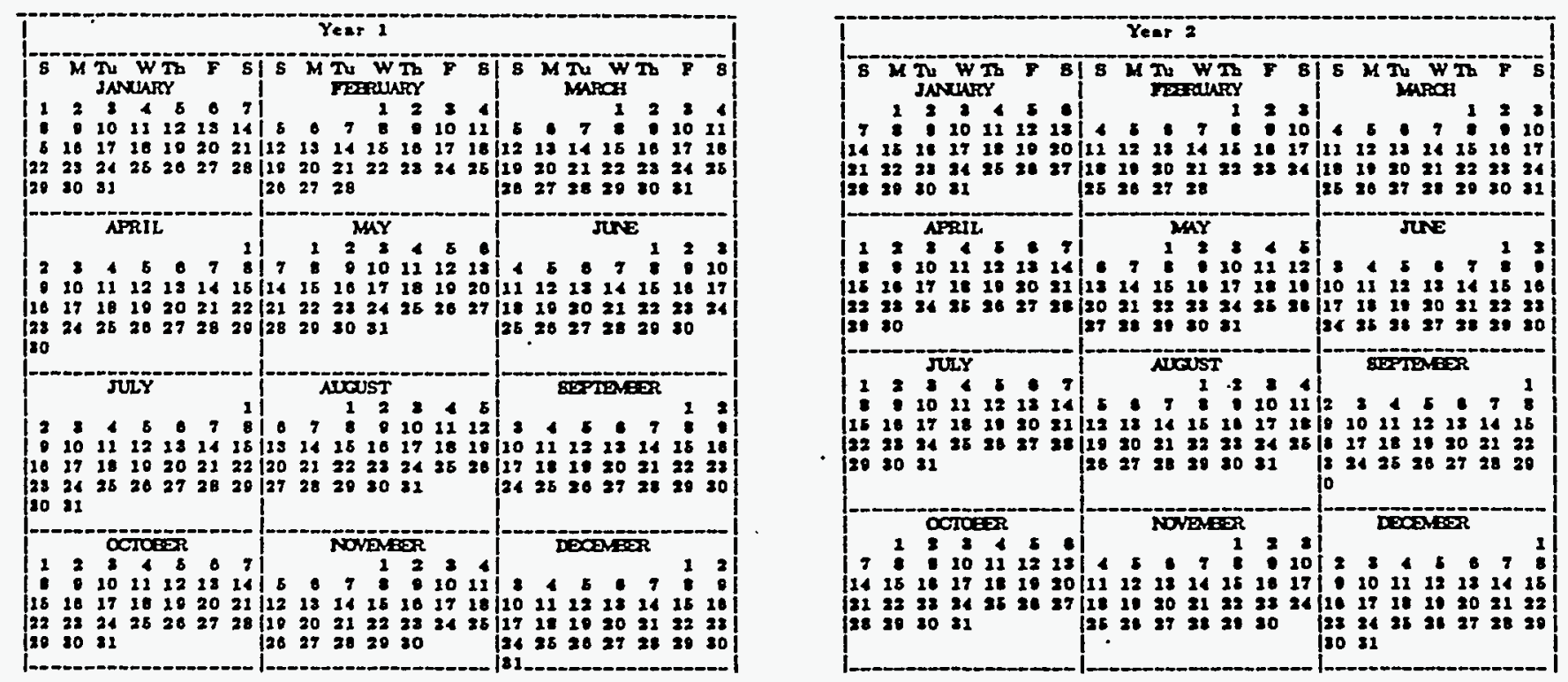

Nole: The program and the weather files use a 365 day year even for leap years. Therefore, in leap years, the calendar and the program Bet one day out of step with regard to days of the week after February 29 . When using the perpetual calendar for leap years, shift back one day of the week for dales after February 28. 


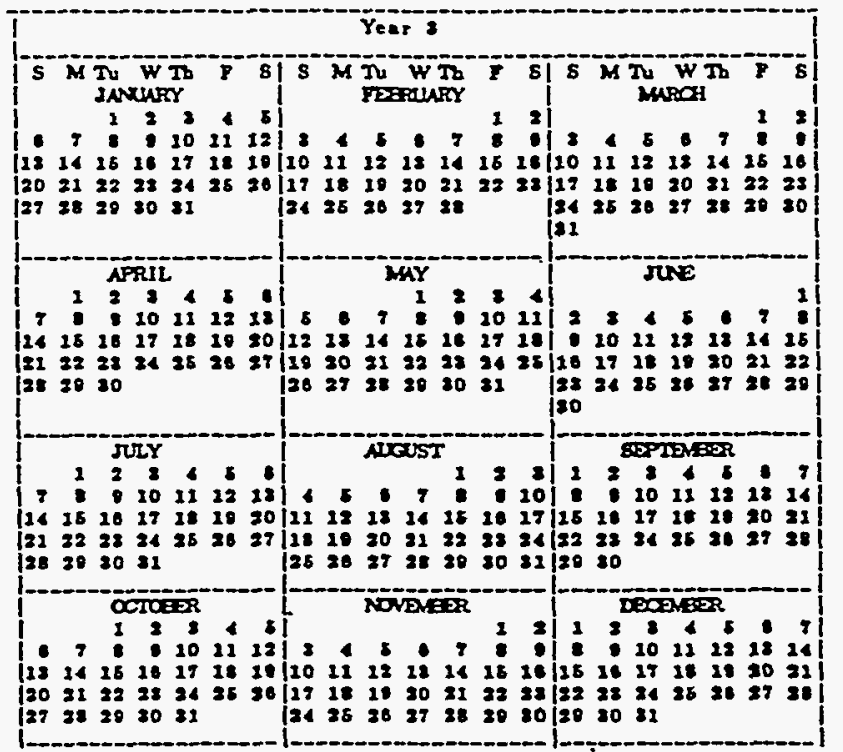

\begin{tabular}{|c|c|c|c|c|}
\hline \multicolumn{5}{|c|}{ Yeas 8} \\
\hline 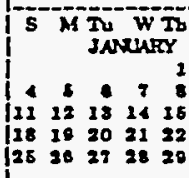 & 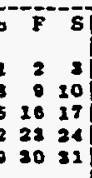 & 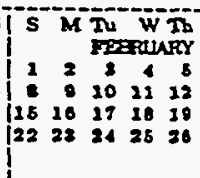 & $\begin{array}{ccc}5 & -7 & 5 \\
5 & 0 & 7 \\
52 & 12 & 14 \\
19 & 20 & 21 \\
36 & 27 & 28\end{array}$ & 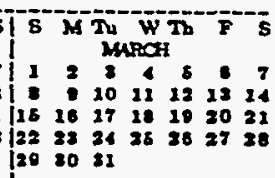 \\
\hline 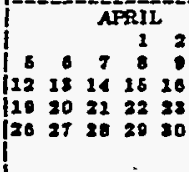 & $\mid \begin{array}{ll}2 & 1 \\
20 & 11 \\
17 & 18 \\
24 & 25 \\
0\end{array}$ & 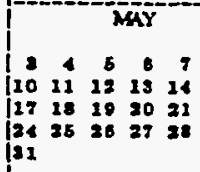 & $\begin{array}{rr}1 & 2 \\
15 & 10 \\
15 & 22 \\
20 & 28 \\
30 & 80\end{array}$ & 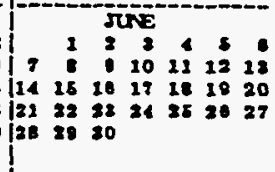 \\
\hline $\mid \begin{array}{rrrrr} & & & & \\
& & & 1 \\
5 & 5 & 7 & 2 & 2 \\
122 & 13 & 14 & 16 & 18 \\
12 & 20 & 21 & 32 & 23 \\
20 & 28 & 28 & 20 & 80\end{array}$ & $\begin{array}{lll}2 & 4 \\
10 & 11 \\
17 & 18 \\
24 & 26 \\
31 & 31\end{array}$ & \begin{tabular}{|lllll} 
& & \\
2 & 2 & 4 & 8 & \\
2 & 10 & 12 & 22 & 12 \\
10 & 27 & 18 & 10 & 20 \\
23 & 24 & 28 & 20 & 27 \\
30 & 31 & & &
\end{tabular} & 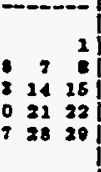 & 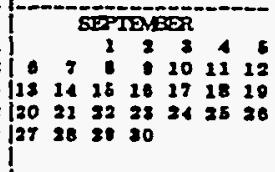 \\
\hline 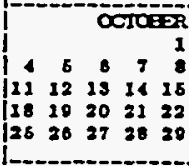 & $\mid \begin{array}{cc}2 & 8 \\
1 & 10 \\
18 & 19 \\
23 & 28 \\
20 & 31 \\
30 & 31\end{array}$ & 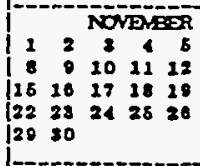 & \begin{tabular}{lll|}
8 & 0 & 7 \\
2 & 18 & 74 \\
2 & 20 & 21 \\
0 & 29 & 28
\end{tabular} & 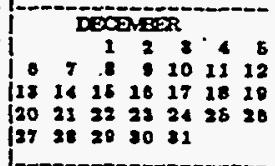 \\
\hline
\end{tabular}

\begin{tabular}{|c|c|c|}
\hline 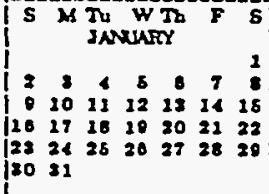 & 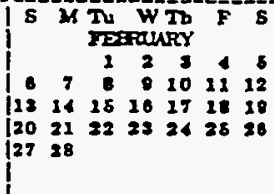 & 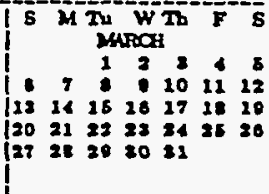 \\
\hline 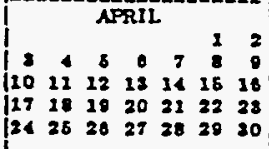 & $\begin{array}{lllllll}1 & 2 & 3 & 1 & 5 & 0 & 7 \\
8 & 8 & 10 & 11 & 12 & 23 & 14 \\
15 & 18 & 17 & 18 & 20 & 20 & 21 \\
22 & 22 & 31 & 25 & 20 & 27 & 38 \\
20 & 30 & 31\end{array}$ & 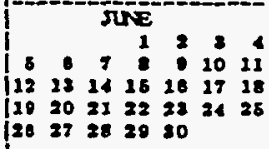 \\
\hline 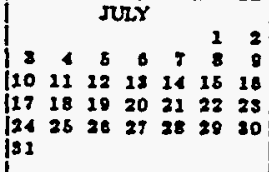 & 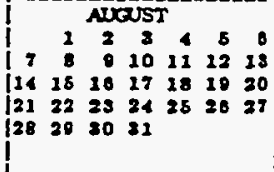 & 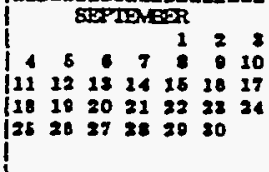 \\
\hline 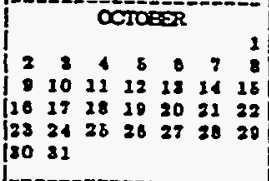 & 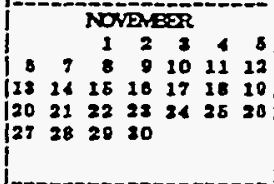 & 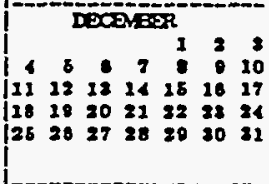 \\
\hline
\end{tabular}

\begin{tabular}{|c|c|c|}
\hline \multicolumn{3}{|c|}{ Year } \\
\hline 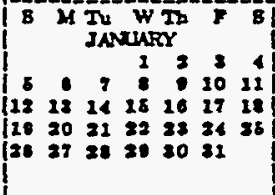 & 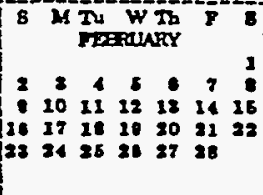 & 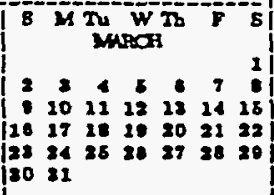 \\
\hline 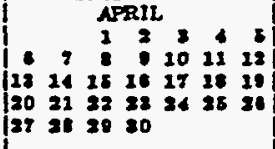 & 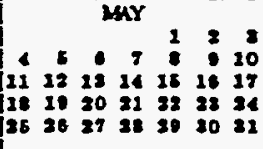 & 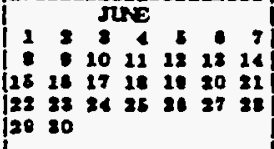 \\
\hline 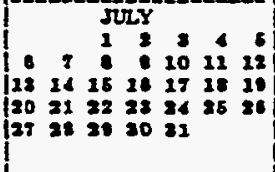 & 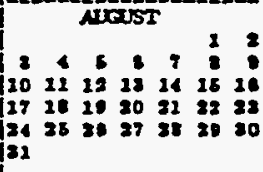 & 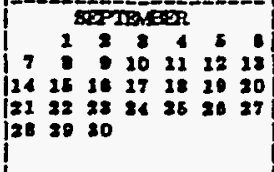 \\
\hline 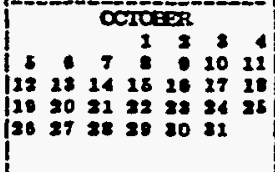 & 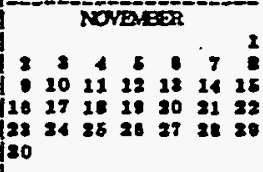 & 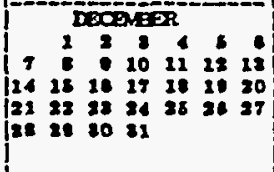 \\
\hline
\end{tabular}

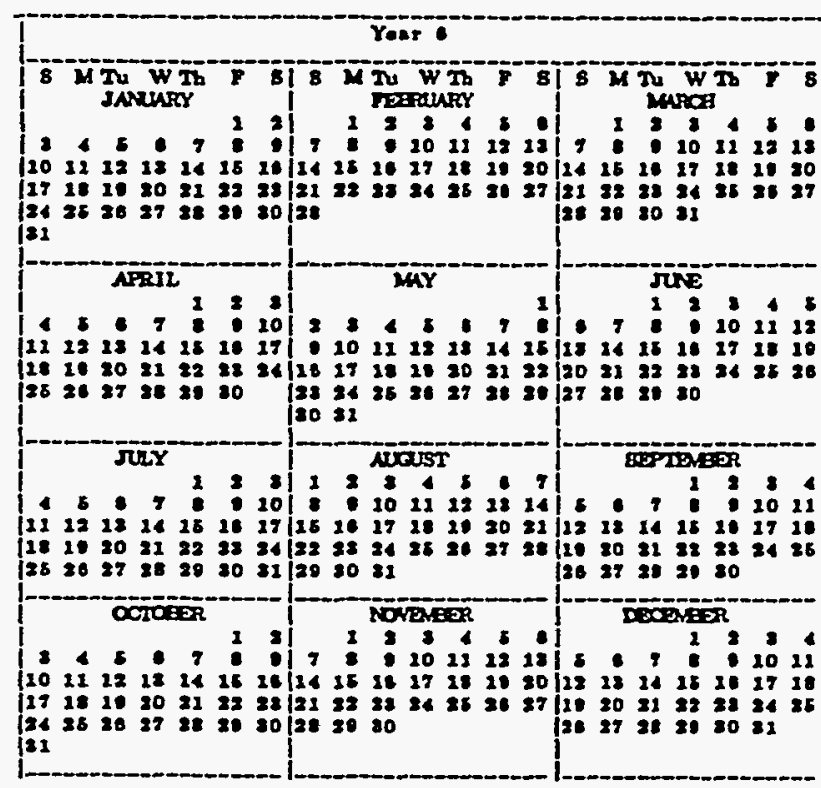

\begin{tabular}{|c|c|c|}
\hline & Year 8 & \\
\hline 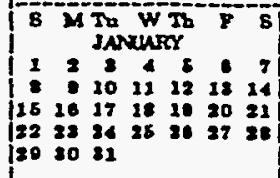 & 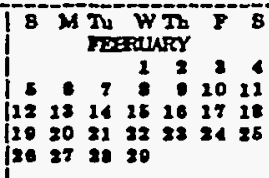 & 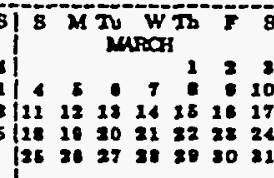 \\
\hline 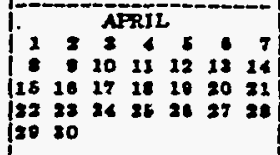 & 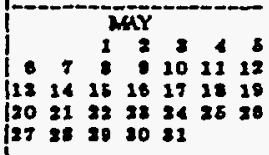 & 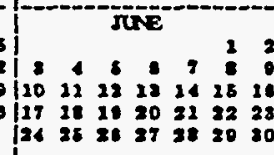 \\
\hline 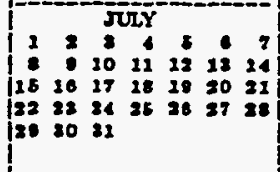 & 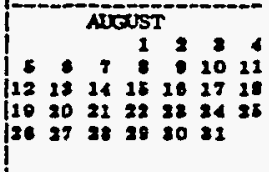 & 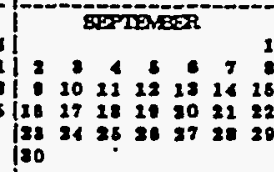 \\
\hline 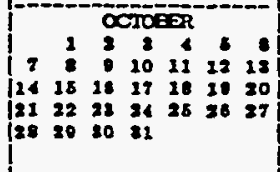 & 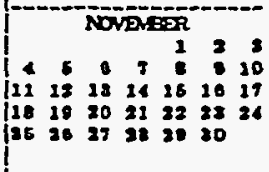 & 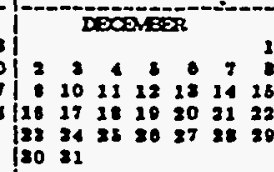 \\
\hline
\end{tabular}




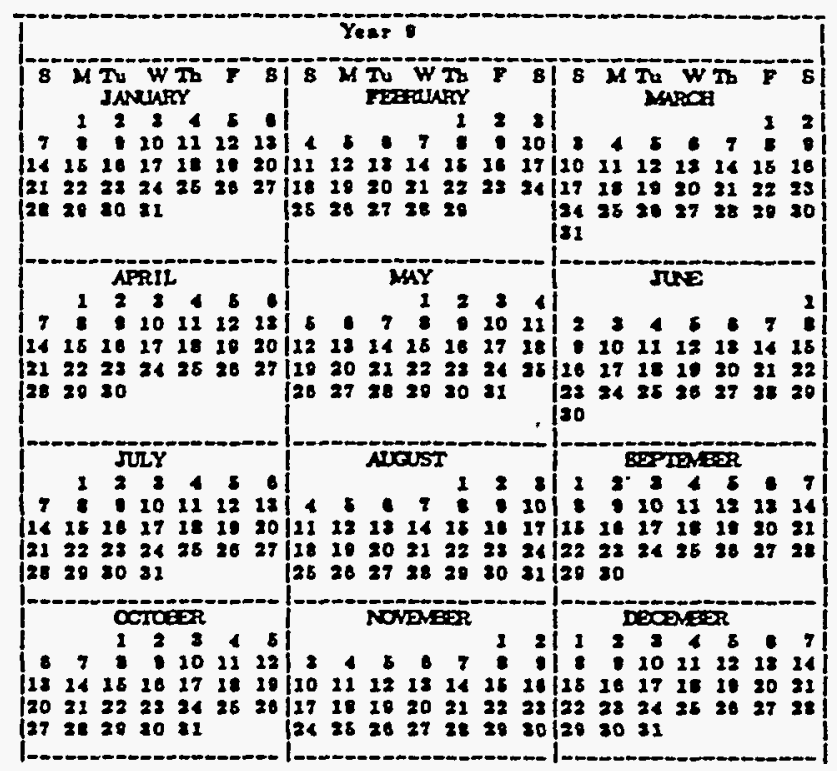

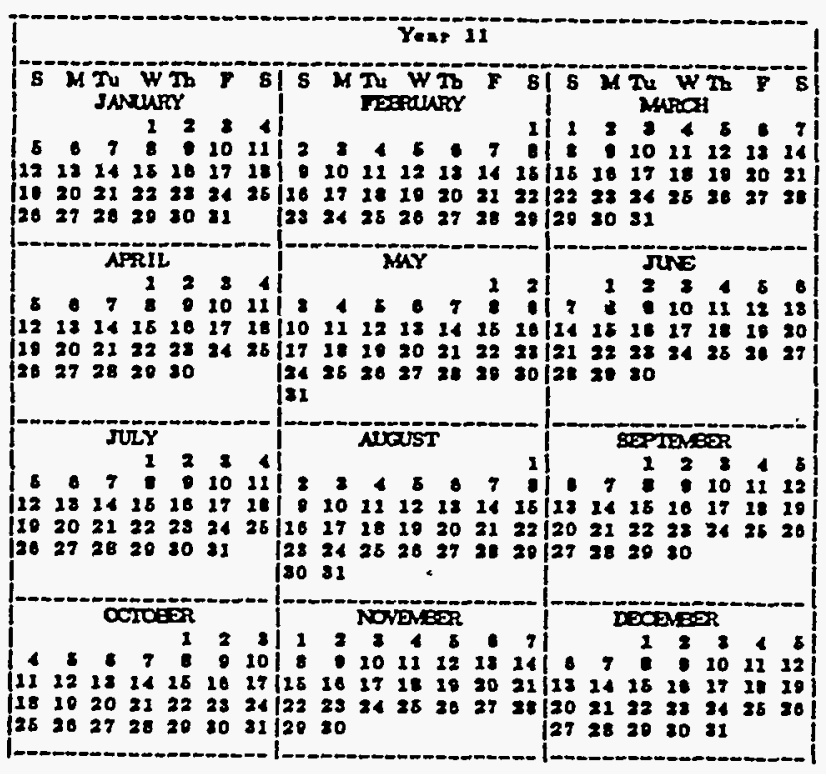

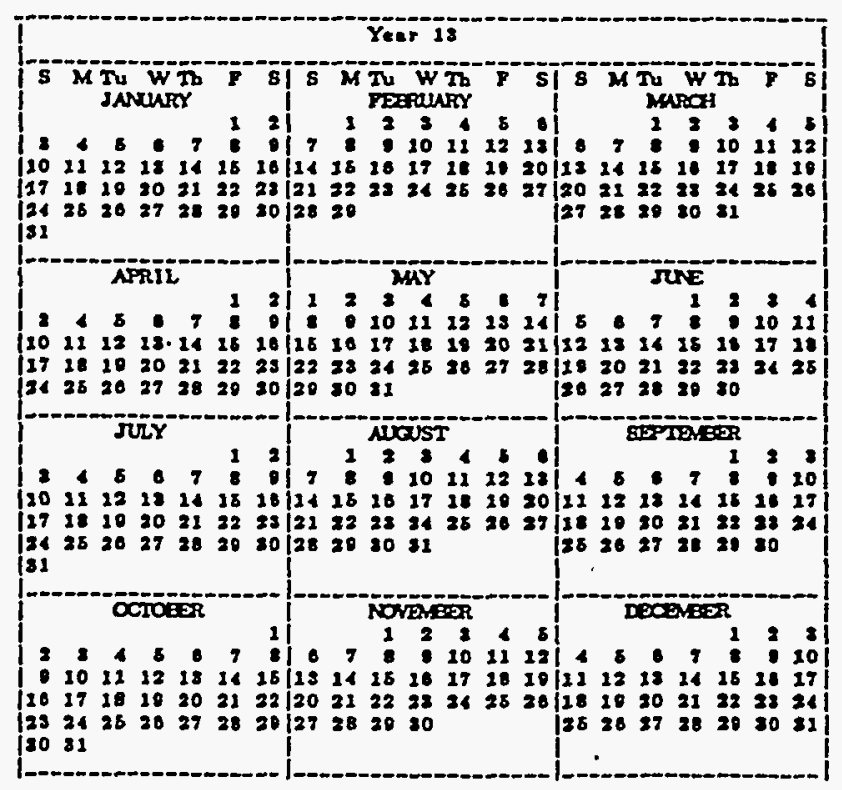

\begin{tabular}{|c|c|c|}
\hline & Year 10 & \\
\hline 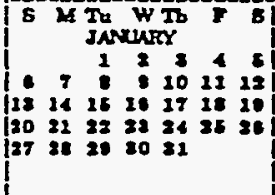 & 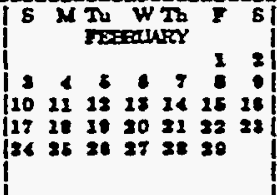 & 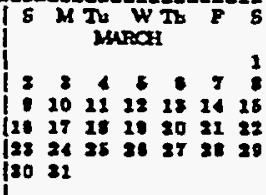 \\
\hline 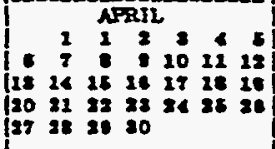 & 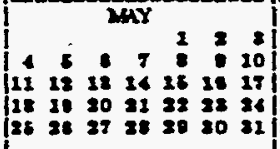 & 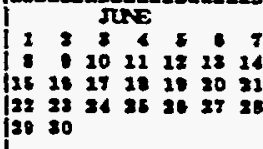 \\
\hline 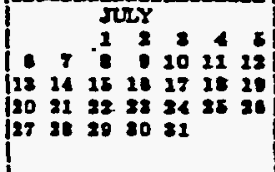 & 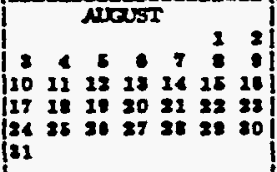 & 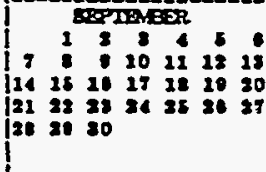 \\
\hline 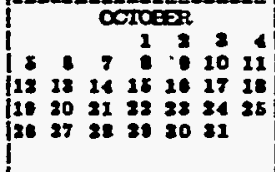 & 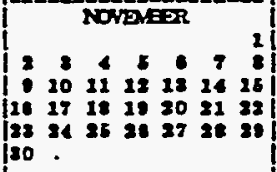 & 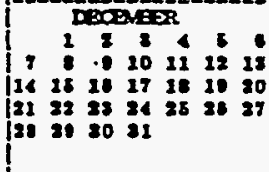 \\
\hline
\end{tabular}

\begin{tabular}{|c|c|c|}
\hline & Yenr I & \\
\hline 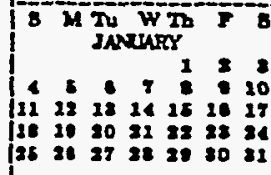 & 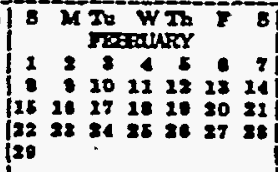 & 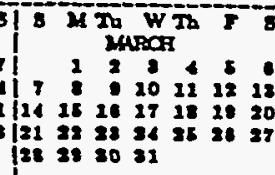 \\
\hline 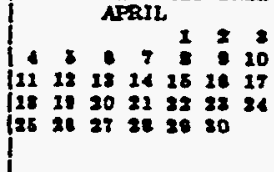 & 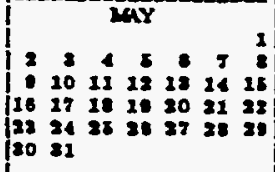 & 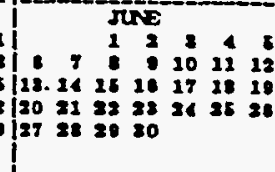 \\
\hline 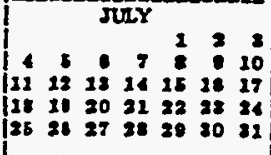 & 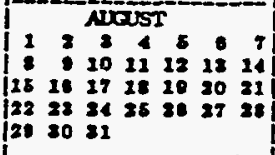 & 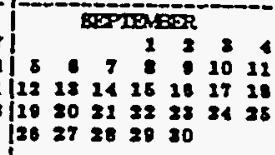 \\
\hline 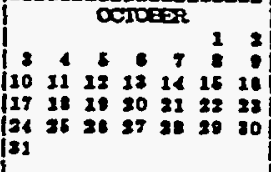 & 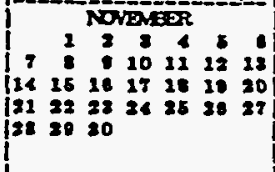 & 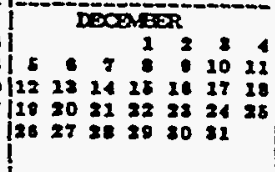 \\
\hline
\end{tabular}

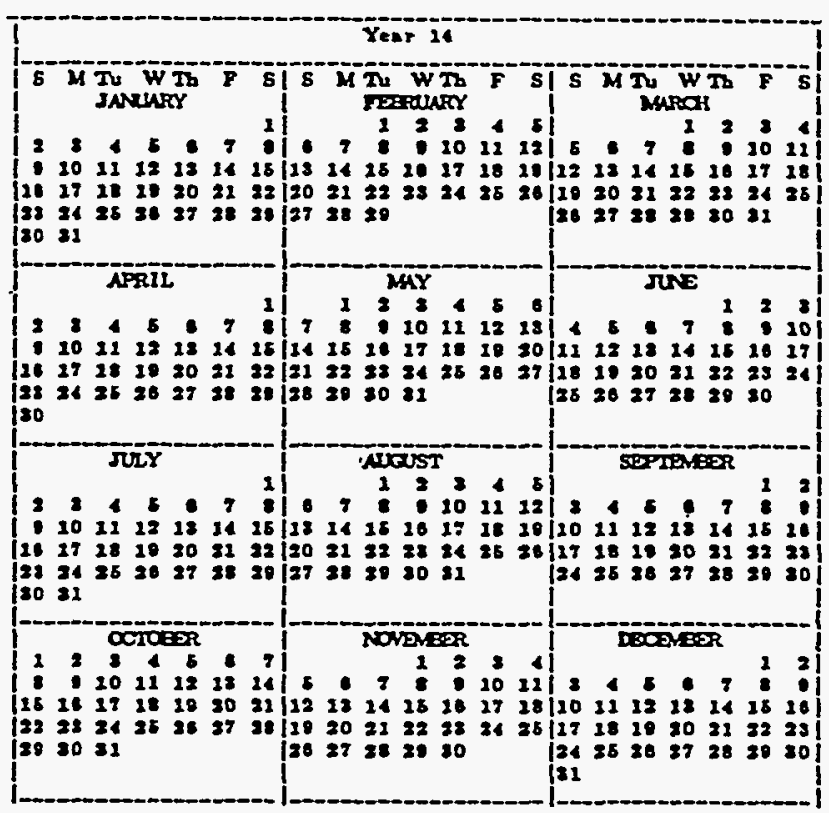

